UNIVERSIDADE DE SÃO PAULO

PROGRAMA DE PÓS GRADUAÇÃO EM ENGENHARIA ELÉTRICA

PEA

CLARISSA PETRACHINI GONÇALVES

Separação Lastro e Energia: Uma análise sob a ótica da Teoria de Opções Reais

São Paulo 
CLARISSA PETRACHINI GONÇALVES

Separação Lastro e Energia: Uma análise sob a ótica da Teoria de Opções Reais

\author{
Versão Revisada
}

Dissertação apresentada à Escola Politécnica da Universidade de São Paulo para obtenção do título de Mestre em Ciências.

São Paulo 
CLARISSA PETRACHINI GONÇALVES

\title{
Separação Lastro e Energia: Uma análise sob a ótica da Teoria de Opções Reais
}

\author{
Versão Revisada
}

Dissertação apresentada à Escola Politécnica da Universidade de São Paulo para obtenção do título de Mestre em Ciências.

Área de Concentração: Sistemas de Potência

Orientador: Prof. Dr. Dorel Soares Ramos

São Paulo 
Autorizo a reprodução e divulgação total ou parcial deste trabalho, por qualquer meio convencional ou eletrônico, para fins de estudo e pesquisa, desde que citada a fonte.

Este exemplar foi revisado e corrigido em relação à versão original, sob responsabilidade única do autor e com a anuência de seu orientador.

São Paulo,

de de

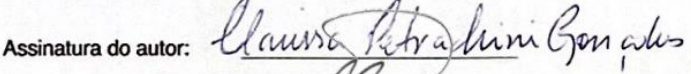

Assinatura do orientador:

Wherms

Catalogação-na-publicação

Gonçalves, Clarissa Petrachini

Separação Lastro e Energia: Uma análise sob a ótica da Teoria de Opções Reais / C. P. Gonçalves - versão corr. - São Paulo, 2020.

$159 \mathrm{p}$.

Dissertação (Mestrado) - Escola Politécnica da Universidade de São Paulo. Departamento de Engenharia de Energia e Automação Elétricas.

1.Mercado de Energia 2.Desenho de Mercado 3.Teoria de Opções Reais 4.Valuation 5.Regulação I.Universidade de Sāo Paulo. Escola Politécnica. Departamento de Engenharia de Energia e Automação Elétricas Il.t. 
Dissertação de autoria de Clarissa Petrachini Gonçalves sob o título "Separação Lastro e Energia: Uma análise sob a ótica da Teoria de Opções Reais", apresentado à Escola Politécnica da Universidade de São Paulo, como parte dos requisitos para obtenção do título de Mestre em Engenharia Elétrica Programa de Pós-graduação em Engenharia Elétrica, na área de concentração Sistemas de Potência, aprovado em 4 de junho de 2020 pela comissão examinadora constituída pelos doutores:

Prof. Dr. Dorel Soares Ramos

Presidente

Instituição: Escola Politécnica da Universidade de São Paulo

Prof. Dr. Donato da Silva Filho

Instituição: Volt Robotics

Prof. Dr. Erik Eduardo Rego

Instituição: Escola Politécnica da Universidade de São Paulo 


\section{AGRADECIMENTOS}

À Deus por permitir que eu chegasse até aqui.

Ao meu pai, Waldir, meu maior exemplo de vida. Obrigada por me ajudar a chegar aqui.

À minha mãe, Ana Paula, e ao meu irmão, André, por todo o apoio, carinho e paciência.

Ao Professor Dorel pela orientação e confiança depositada em mim ao longo de todos esses anos. 


\section{RESUMO}

GONÇALVES, Clarissa Petrachini. Separação Lastro e Energia: Uma análise sob a ótica da Teoria de Opções Reais. 2020. 140 p. Dissertação (Mestrado em Ciências - área de concentração Engenharia Elétrica) - PEA/USP - Depto. de Eng. de Energia e Automação Elétricas, Universidade de São Paulo, São Paulo, 2020

Hoje, a expansão da oferta de energia elétrica, conforme indicada pela Empresa de Pesquisa Energética (EPE), é sustentada majoritariamente pelo Ambiente de Contratação Regulada através dos Leilões de Energia Nova (LEN) promovidos pelo governo brasileiro. Contudo, atualmente o mercado livre já representa praticamente $30 \%$ do consumo total de energia no país e deve continuar expandindo, não só pela atratividade da possibilidade de escolha do seu próprio fornecedor, mas também por conta das intenções governamentais em fomentar a expansão deste ambiente de contratação. Dado isso, caso as próprias forças de mercado e a regulação vigente não sejam suficientes para estimular a expansão da geração também por participantes do ambiente de contratação livre, corre-se o risco de ficar com um parque gerador aquém das necessidades da sociedade brasileira.

Nesse contexto, o governo propôs a separação dos produtos Lastro e Energia como possível solução para a questão. O presente trabalho visa realizar uma avaliação econômico-financeira da viabilidade da comercialização pelos geradores do setor elétrico brasileiro, considerando os produtos Lastro e Energia em separado, o que difere da modalidade de contratação de energia vigente. Para isso, as mudanças propostas no modelo de contratação serão avaliadas, para os diferentes tipos de fontes de geração, sob a ótica da Teoria das Opções Reais (TOR), que permite inserir incertezas na análise de investimentos com o suporte de uma modelagem estocástica para as principais variáveis influentes.

Palavras-chave: Usina Hidroelétrica. Usina Eólica. Teoria das Opções Reais. Desenho de Mercado. 


\begin{abstract}
GONÇALVES, Clarissa Petrachini. Capacity and Energy segregation: an analysis under the Real Options Theory perspective. 2020. 140 p. Dissertation (Master in Electrical Engineering) - PEA/USP - Electrical Energy and Automation Department, Universidade de São Paulo, São Paulo, 2020
\end{abstract}

Nowadays in Brazil, the electricity generation expansion is planned by The Energy Research Office and sustained mainly through investments on the regulated auctions promoted by the Brazilian government. Although, the free market represents almost $30 \%$ of country's total energy consumption and should still expand soon mostly on government intentions on fostering it. Given that, if market dynamics and existing regulation together are not enough for stimulating the generation expansion in the free market, the country may run the risk of having a generation fleet smaller than its real necessities.

In this context, the Brazilian government proposed the segregation of contracts in two products - Capacity and Energy - as a possible solution to the matter. This work intends to evaluate the financial and economic availability for generators to commercialize those segregated products. Beyond that, the changes proposed for the Power Purchase Agreement structure are going to be evaluated under the Real Options Theory perspective, thus allowing the consideration of different sources of uncertainties with the support of stochastic modeling for the main variables that drive value to the power plants.

Keywords: Hydroelectric Power Plant. Wind Power Plant. Real Options Theory. Market Design. 


\section{LISTA DE FIGURAS}

Figura 1: Consumo de energia elétrica no Brasil.

Figura 2: Histórico do Consumo de Energia no Ambiente de Contratação Livre. 5

Figura 3: Histórico de Geração de Energia Elétrica no Brasil por Tipo de Fonte. 6

Figura 4: Ilustração do Missing Money Problem.

Figura 5: Estrutura do Planejamento do Setor Elétrico Brasileiro ao Final dos Anos 80

Figura 6: Estrutura Integrada de ECCs 26

Figura 7: Estrutura de mercado balizadora do modelo Re-seb. 27

Figura 8: Estrutura e Funcionalidades dos CCEARs e CCVEEs Conforme Modelo Vigente 30

Figura 9: Estrutura do balanço patrimonial 39

Figura 10: Como Chegar no Fluxo de Caixa de Um Projeto 40

Figura 11: Cálculo do Fluxo de Caixa do Acionista através do NOPAT 42

Figura 12: Cálculo do Fluxo de Caixa do Acionista através do Lucro Líquido 42

Figura 13: Exemplo numérico de cálculo do Fluxo de Caixa Livre da Firma e do Acionista. 43

Figura 14: Países que utilizam o WACC ou outra metodologia para a Taxa De Retorno Regulatória. 45

Figura 15: Evolução do custo de capital aproximado de projetos em novas fontes renováveis. Fonte: FGV Energia, Anbima, Banco Central do Brasil e BNDES .... 45

Figura 16: Opção por Títulos Públicos Domésticos ou Estrangeiros na Definição da Taxa de Remuneração do Capital do Setor Elétrico. 48 
Figura 17: Estrutura de Capital para diferentes setores da economia. Fonte: Ministério da Fazenda. 55

Figura 18: Custo de Investimento em Hidrelétricas nos Leilões Regulados. 56

Figura 19: Custo de Investimento em UHEs e PCHs com Base em Diferentes Referências

Figura 20: Parâmetros Econômicos das UHEs Consideradas. 57

Figura 21: Custo de Investimento em Termelétricas movidas a Gás Natural nos Leilões Regulados 58

Figura 22: Custo de Investimento em Termelétricas Movidas a Gás Natural de Ciclo Combinado com Base em Diferentes Referências 58

Figura 23: Custo de Investimento em Plantas Eólicas nos Leilões Regulados 59

Figura 24: Custo de Investimento em Eólicas com Base em Diferentes Referências .... 59

Figura 25: Custo de Investimento em Plantas Solares nos Leilões Regulados 60

Figura 26: Custo de Investimento em Eólicas com Base em Diferentes Referências .... 60

Figura 27: Evolução Prevista do Custo de Investimento em Sistemas Fotovoltaicos.... 61

Figura 28: Custo de Investimento em Plantas Movidas a Biomassa nos Leilões Regulados 61

Figura 29: Custo de Investimento em Biomassa com Base em Diferentes Referências 62 Figura 30: Preço Anual Média do GNL importado no Brasil em US\$/mnBtu. 64

Figura 31: Preço Anual Médio do GNL importado no Brasil em R $\$$ MWh 65

Figura 32: Estimativas de break-even do gás natural do Pré-sal. Fonte: (EPE, 2019a). 65

Figura 33: Contratos de O\&M tipo "full service" (iniciais e renovação), média ponderada da receita de O\&M de dois produtores e custos de O\&M na Dinamarca, Alemanha, Irlanda e Suécia entre 2008 e 2017. 66 
Figura 34: Ilustrações das Posições Long e Short na Call

Figura 35: Ilustrações das Posições Long e Short na Put 73

Figura 36: Modelo Binomial 73

Figura 37: Tipos de Opções Reais 78

Figura 38: Método Geral: Processo de 4 passos. 81

Figura 39: Diferentes Métodos de Precificação de Opções Reais 83

Figura 40: Maneiras de calcular o valor presente 85

Figura 41:Uso da Simulação de Monte Carlo para um Modelo de Valor Presente........ 90

Figura 42: Resultados para o Preço-teto do Lastro (R $\$$ MWh) para diferentes Taxas de Retorno do Acionista. 100

Figura 43: Média e Percentis das séries de PLD utilizadas na simulação 102

Figura 44: Média e Percentis dos cenários de GSF 103

Figura 45: Reconstrução de Séries Temporais de Vento - Etapa I. 105

Figura 46: Geração diária com série reconstituída - Etapa II. 106

Figura 47: Média e Percentis da Geração Eólica Por Unidade de Potência. 106

Figura 48: Árvore de Eventos do Estudo de Caso 108

Figura 49: Valor Presente do Projeto Hidrelétrico sem Flexibilidade para Diferentes Valores de Lastro 111

Figura 50: Volatilidade da Taxa de Retorno do Projeto Hidrelétrico para diferentes valores de Lastro 112

Figura 51: Valor Presente do Projeto com a Opção de Espera para Diferentes Valores de Lastro 112 
Figura 52: Árvores Binomiais da Opção de Espera para o Investimento no Projeto Hidrelétrico Considerando Diferentes Valores de Lastro 113

Figura 53: Valor Presente Líquido do Projeto Hidrelétrico para Diferentes Prazos de Espera. 114

Figura 54: Valor Presente do Projeto com a Opção de Espera para Diferentes Valores de Lastro - Caso com Preços Estressados 115

Figura 55: Valor Presente do Projeto Hidro-eólico sem Flexibilidade para Diferentes Valores de Lastro da Usina Hidrelétrica ..... 117

Figura 56: Volatilidade da Taxa de Retorno do Projeto Hidro-eólico para diferentes valores de Lastro da Usina Hidrelétrica 118

Figura 57: Valor Presente do Projeto Hidro-eólico com a Opção de Espera para Diferentes Valores de Lastro da Usina Hidrelétrica .... 118

Figura 58: Árvores Binomiais da Opção de Espera para o Investimento no Projeto Hidroeólica Considerando Diferentes Valores de Lastro da Usina Hidrelétrica 119

Figura 59: Valor Presente Líquido do Projeto Hidro-eólico para Diferentes Prazos de Espera. 120

Figura 60: Ganho do Custo de Oportunidade no Investimento em Conjunto no Projeto Hidro-eólico 121

Figura 61: Valor Presente do Projeto com a Opção de Espera para Diferentes Valores de Lastro - Caso com Preços Estressados 122

Figura 62: Valor Presente Líquido do Projeto Hidro-eólico sem Flexibilidade para Diferentes Valores de Lastro da Hidrelétrica e da Eólica 123

Figura 63: Volatilidade do Retorno do Projeto Hidro-eólico para Diferentes Valores de Lastro da Hidrelétrica e da Eólica 124

Figura 64: Comportamento do Valor Presente Líquido com Flexibilidade do Projeto Hidro-eólico 124 
Figura 65: Comportamento da Opção de Espera do Projeto Hidro-eólico

Figura 66: Comportamento da Opção de Espera do Projeto Hidro-eólico no Caso

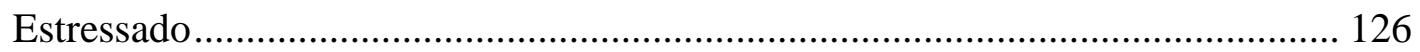




\section{LISTA DE TABELAS}

Tabela 1: Tabela 2: Betas utilizados pela ANEEL em processos de Revisão Tarifária Periódica

Tabela 3: Histórico do prêmio de risco de mercado utilizado pela ANEEL nos processos de revisão tarifária.

Tabela 4: Histórico das Decisões da ANEEL sobre a Participação do Custo de Capital de Terceiros na Estrutura de Capital Regulatória.

Tabela 5: Custos de O\&M para a geração hidrelétrica.

Tabela 6: Custos de O\&M para a geração termelétrica a gás natural de ciclo combinado.

Fonte: EPE

Tabela 7: Heat rate médio testado para o combustível gás natural em planta de ciclo combinado. 64

Tabela 8: Custo de O\&M das eólicas

Tabela 9: Custo de O\&M das Usinas Solares Fotovoltaicas

Tabela 10: Variáveis da TOR vs. Variáveis de uma Call. 79

Tabela 11: Preços de Energia no Mercado de Curto Prazo (R $\mathbf{M W h}$ ) 96

Tabela 12: Premissas para o Estudo de Caso Estático. 99

Tabela 13: Resultados para o Preço-teto do Lastro (R $\$$ MWh) para diferentes Taxas de Retorno do Acionista. 100

Tabela 14: Valor Presente Líquido do Projeto com Opção de Espera em Diferentes Períodos 114

Tabela 15: Valor Presente Líquido do Projeto com Opção de Espera em Diferentes Períodos. 


\section{SIGLAS}

ACL Ambiente de Contratação Livre

ACR Ambiente de Contratação Regulado

ANEEL Agência Nacional de Energia Elétrica

AP Audiência Pública

BNDES Banco Nacional do Desenvolvimento

CCEAR Contrato de Compra e Venda de Energia no Ambiente Regulado

CCEE Câmara de Comercialização de Energia Elétrica

CCVEE Contrato de Compra e Venda de Energia no Ambiente Livre

CME Custo Marginal de Expansão

CMO Custo Marginal de Operação

CNPE Conselho Nacional de Política Energética

CP Consulta Pública

DC Decomp

EPE Empresa de Pesquisa Energética

LEN Leilão de Energia Nova

LER Leilão de Energia de Reserva

MAE Mercado Atacadista de Energia

MCP Mercado de Curto Prazo

MME Ministério de Minas e Energia

NW Newave

ONS Operador Nacional do Sistema

PIE Produtor Independente de Energia

PLD Preço de Liquidação de Diferenças

SEB Setor Elétrico Brasileiro

SIN Sistema Interligado Nacional

WACC Weighted Average Cost of Capital 


\section{SUMÁRIO}

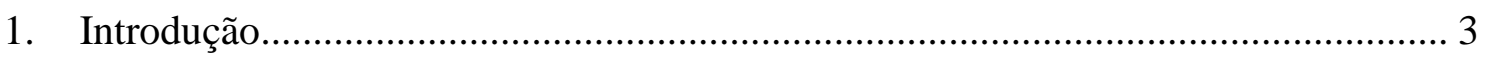

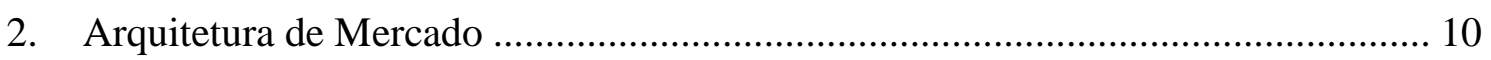

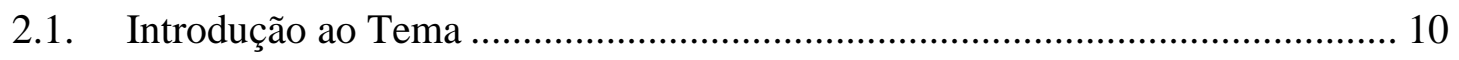

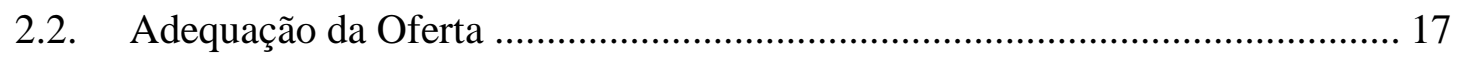

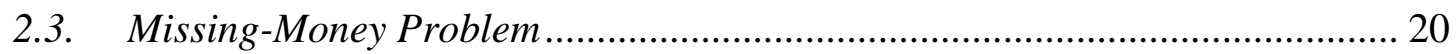

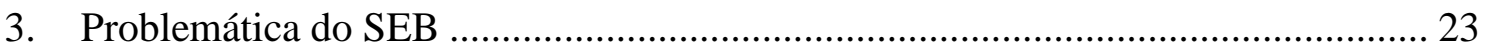

3.1. Uma Breve História do SEB Sob a Óptica da Expansão ................................. 23

3.2. Modelo de comercialização de energia vigente ............................................. 29

3.3. Garantia Física: $\mathrm{O}$ mecanismo de confiabilidade vigente ............................. 31

3.4. Proposta do Governo para Separação dos Produtos Lastro e Energia .............. 35

3.5. Considerações Finais do Capítulo................................................................. 35

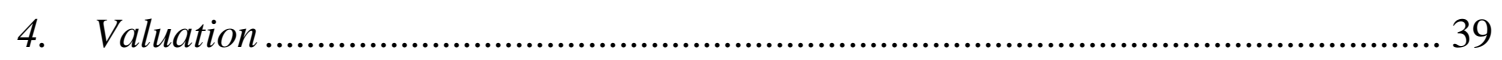

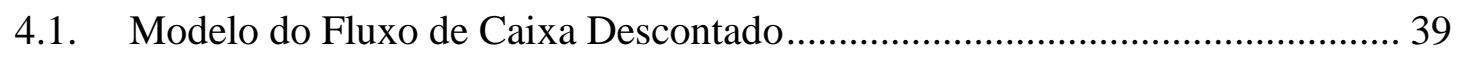

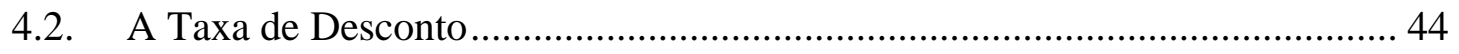

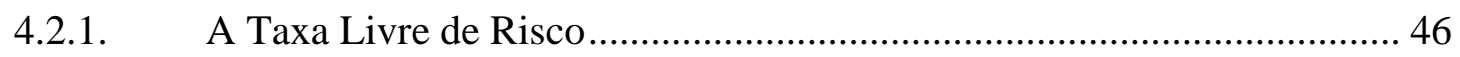

4.2.2. Custo de Capital de Terceiros................................................................. 48

4.2.3. Custo do Capital Próprio ......................................................................... 50

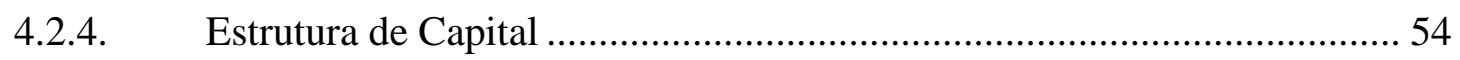

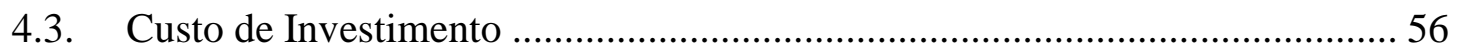

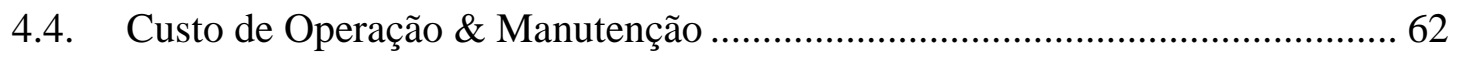

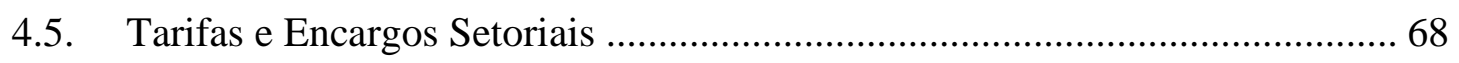

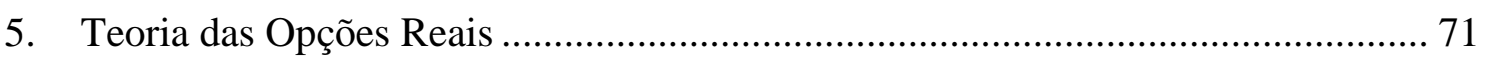

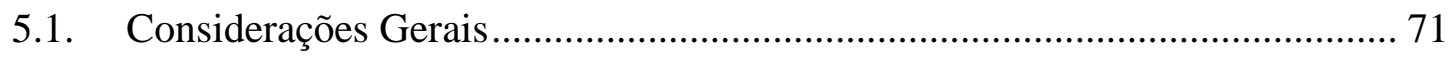

5.2. Conceito dos Contratos de Opções Financeiras ........................................... 71 
5.3. Aplicando o Conceito de Precificação de Opções Financeiras em Opções Reais 78

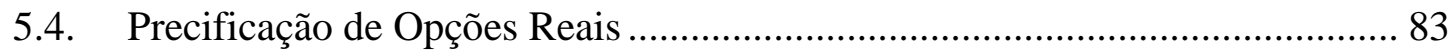

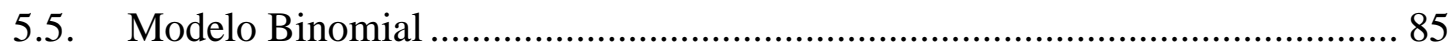

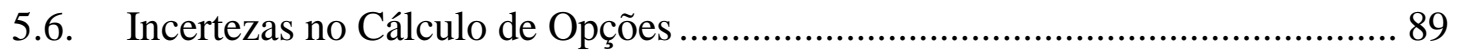

5.7. Breve Histórico das Opções Reais .................................................................... 91

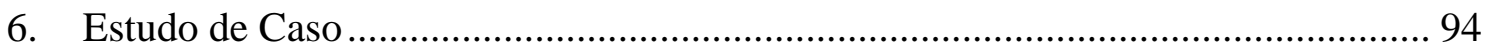

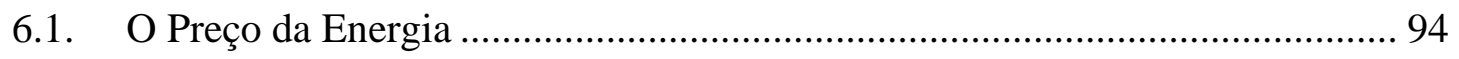

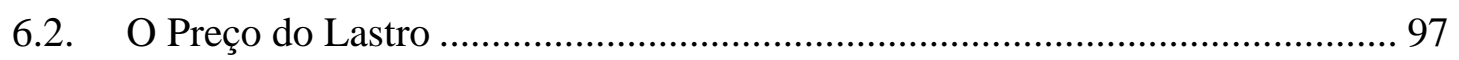

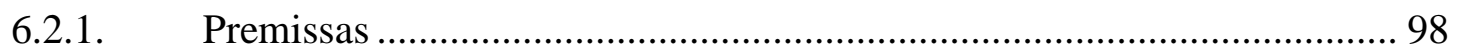

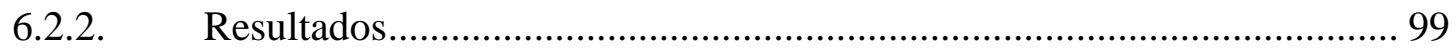

6.3. Análise de Investimento sob a Óptica das Opções Reais ............................. 100

6.3.1. Preços de Lastro e Energia ................................................................. 100

6.3.2. Geração Hidráulica e sua Comercialização ............................................ 102

6.3.3. Geração Eólica e sua Comercialização.................................................... 103

6.3.4. O Valor de Adiar o Investimento (Opção de Espera).............................. 107

6.3.5. Análise de Investimento em uma Hidrelétrica ................................... 110

6.3.6. Análise de Investimento em uma Hidrelétrica e uma Eólica Quando a Eólica

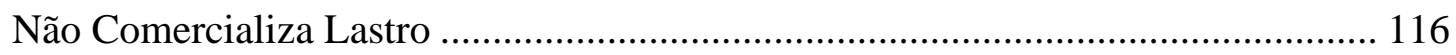

6.3.7. Análise de Investimento em uma Hidrelétrica e uma Eólica Quando a Eólica Comercializa Lastro

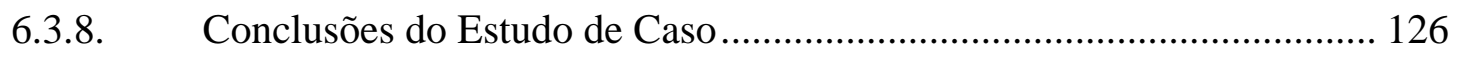

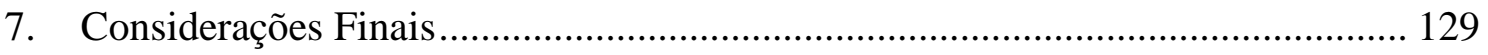

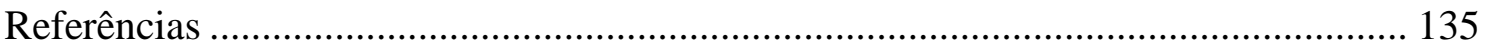




\section{INTRODUÇÃO}

Assim como sucedeu ao redor do mundo, o Brasil também passou por um processo "liberalização" de seu setor elétrico. No início dos anos 90, as discussões giravam em torno da globalização da economia, através de internacionalização dos mercados, redução de protecionismos tarifários, diminuição de barreiras comerciais e de reservas de mercado. Além disso, o liberalismo econômico era promovido amplamente por agências multilaterais, o que culminou no Consenso de Washington. Neste contexto, o expresidente do Brasil, Fernando Color, deu início ao Plano Nacional de Desestatização.

Anos mais tarde, durante o governo do ex-presidente Fernando Henrique Cardoso, a reestruturação do setor elétrico brasileiro teve início, com o conhecido projeto "Re-seb", que tinha por principais objetivos, desverticalizar e privatizar, com o intuito de permitir a existência de um ambiente competitivo na geração e comercialização de energia, além de garantir livre acesso aos sistemas de transmissão e distribuição. Contudo, o funcionamento do mercado não evoluiu conforme esperavam os técnicos. O ambiente regulatório inadequado e um processo de planejamento com falhas de coordenação, trouxeram ao governo a necessidade de estimular a expansão da oferta através de programas como o Programa de Geração Emergencial (1999) e o Programa Prioritário Termelétrico (2000).

Sabe-se que planejamento da expansão deve primar pela segurança e confiabilidade no fornecimento de energia, através do menor custo possível para o consumidor final e da minimização de impactos socioambientais. Além disso, o adequado planejamento da expansão é ponto fundamental para o desenvolvimento da economia de qualquer país, dado o grau de dependência dos demais setores da economia em relação a este. Qualquer desvio do planejamento realizado em relação ao crescimento efetivo da demanda por energia elétrica, pode levar a sobra ou falta deste recurso, o que em último poderia implicar em racionamento.

O Brasil enfrentou por anos os impactos do racionamento de energia elétrica decretado em 2001 pelo governo do então Presidente da República Fernando Henrique Cardoso. Conforme (GOLDENBERG e PRADO, 2003), ficou evidente que o principal fator responsável por quase $2 / 3$ do racionamento, estava ligado à não implementação de novas usinas. A economia de energia no país durante o racionamento foi de $46.794 \mathrm{GWh}$, ou $23,8 \%$, mas a redução do consumo não ficou restrita ao período de racionamento, permanecendo em menor intensidade (BARDELIN, 2004). 
Goldenberg e Prado dão uma dimensão do impacto financeiro do racionamento de energia elétrica para sociedade brasileira em (GOLDENBERG e PRADO, 2003):

\begin{abstract}
"Com o término do racionamento devido à volta da estação de chuvas e a colaboração da sociedade nas metas de economia de eletricidade, o Governo Federal, a partir de dezembro de 2001, por medida provisória, instituiu um conjunto de medidas com objetivo de gerenciar a crise e promover sua superação, incluindo uma recomposição tarifária (devido ao período do racionamento) com adiantamentos de recursos do BNDES e, para evitar novos racionamentos, a compra de energia elétrica emergencial pela empresa estatal criada especialmente para esse fim, a CBEE (Comercializadora Brasileira de Energia Emergencial). Essas duas medidas, com um custo estimado de mais de $\mathrm{R} \$ 20$ bilhões, criaram uma viva polêmica na sociedade, inclusive sobre a real necessidade de energia emergencial, pois o racionamento induziu a população a estabelecer padrões de consumo elétrico mais eficientes."
\end{abstract}

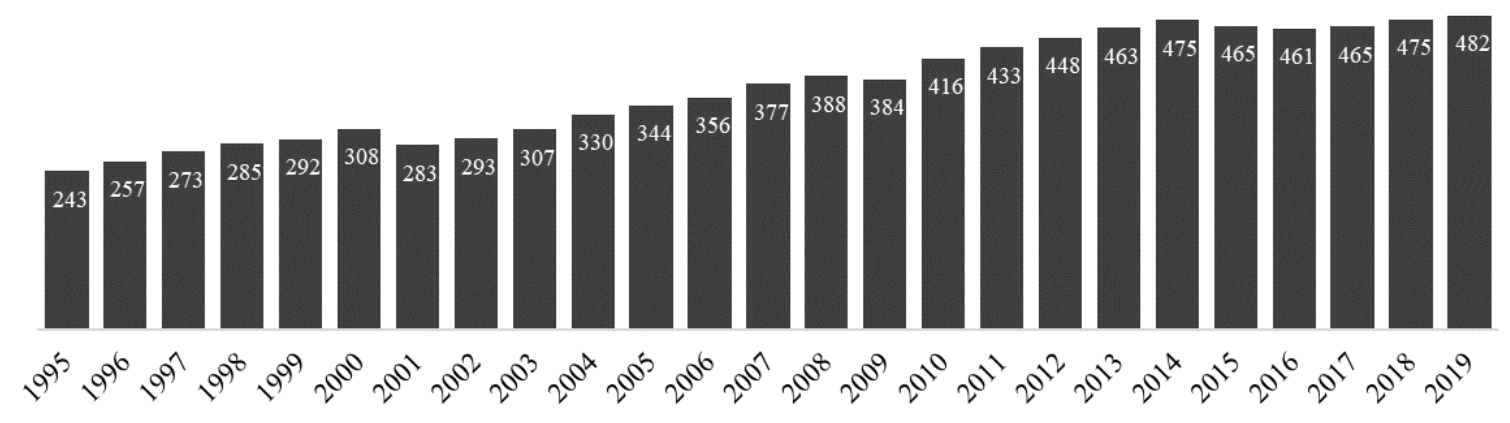

Figura 1: Consumo de energia elétrica no Brasil.

Fonte: Autora

Em 2004, através da Lei 10.848 o governo constitui a base da legislação para os leilões no Ambiente de Contratação Regulada (ACR). Tal mecanismo foi criado com o intuito de conferir ao governo uma maior coordenação da expansão da geração.

Contudo, vale ressaltar que a desverticalização do setor elétrico brasileiro jamais foi concluída conforme desenhada à época, uma vez que, a comercialização de energia à maioria dos consumidores de média tensão e à totalidade dos consumidores de baixa tensão continua sendo exclusividade das distribuidoras de energia elétrica.

Mesmo com limitações presentes na legislação vigente, a crescente migração de consumidores para o Ambiente de Contratação Livre (ACL), vem demandando uma revisão da arquitetura de mercado atual que permita a todos os agentes participarem igualitariamente da expansão da oferta de energia elétrica no país, no que se refere à custos, riscos e responsabilidades. 
Em 2018, o ACL representou em média 30\% consumo total de energia no país. Quando se observa pelo lado da indústria o consumo no mercado livre se torna ainda mais expressivo. Em 2017, representou $77 \%$ de todo o consumo da classe industrial.

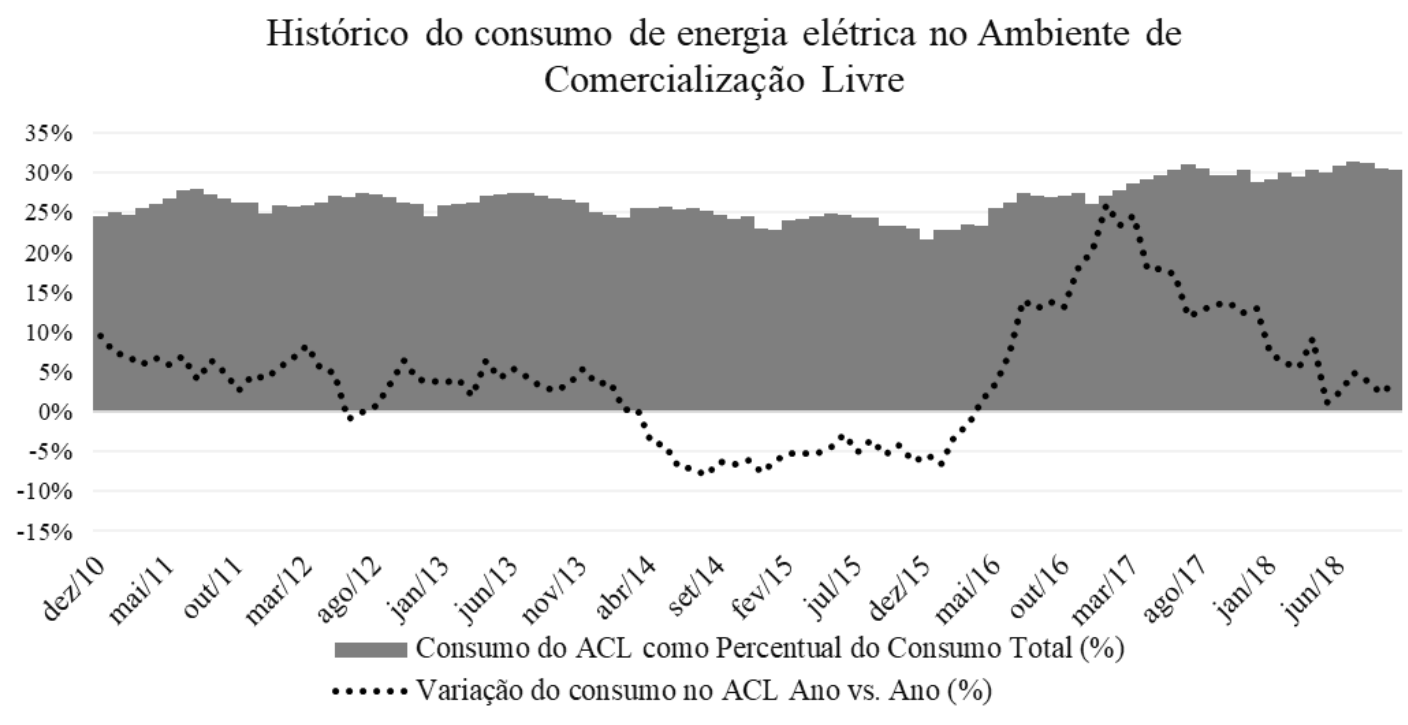

Figura 2: Histórico do Consumo de Energia no Ambiente de Contratação Livre.

Fonte: Autora

Soma-se a isso, o fomento advindo do próprio Governo Federal para a expansão do mercado livre de energia elétrica. Recentemente, o Ministério de Minas e Energia externou um conjunto de intenções que englobavam grandes mudanças no desenho de mercado, conforme discutido no âmbito da CP no 033/2017 e, atualmente, no Projeto de Modernização do Setor Elétrico. Essas mudanças afetam diretamente o funcionamento adequado do processo de expansão da oferta e, dentre os temas abordados e incluídos no PL n²32, está a expansão do mercado livre (ACL) que, apesar de ser desejável, necessita que outros mecanismos sejam aprovados e instituídos concomitantemente, como forma de garantir a adequação da oferta.

Deve-se ressaltar que, a escassez, por si só, não é condição suficiente para que os consumidores de energia do mercado livre façam as escolhas mais adequadas quando o assunto é expansão do parque gerador.

Imperfeições e distorções criadas pela própria arquitetura do mercado atual limitam que os princípios econômicos das leis de oferta e demanda ajam isoladamente de forma a contribuir para uma expansão com as caraterísticas necessárias de confiabilidade e segurança. 
Soma-se a isso, a forte e rápida expansão das fontes renováveis e a diminuição da capacidade de regularização dos reservatórios frente ao crescimento da carga, que trazem desafios adicionais às decisões de expansão da oferta de geração no país. Cada vez mais o Operador Nacional do Sistema Elétrico (ONS) precisa atentar para as características individuais de cada tipo de fonte, buscando atender às necessidades específicas de demanda de ponta de cada região. Ou seja, para que a expansão do parque gerador atenda completamente as necessidades da sociedade, não basta garantir a expansão da capacidade instalada em MW, mas sim garantir a expansão de uma oferta que seja suprida por fontes adequadas às reais necessidades do sistema elétrico brasileiro.

No gráfico abaixo, onde temos o histórico de geração por tipo de fonte no Brasil, podemos notar como a geração hidrelétrica perdeu representatividade no atendimento à demanda. Em 2001, mesmo com o racionamento decretado e reservatórios em níveis críticos, a geração hidrelétrica correspondeu ao atendimento de $90 \%$ da demanda do país.

Já em 2018, apesar de condições hidrológicas também críticas, porém em menor escala do que no ano de 2001, a geração hidrelétrica correspondeu à apenas $71 \%$ do atendimento à demanda total. Pode-se atribuir este fato não só às condições hidrológicas, mas também ao resultado de importantes mudanças regulatórias e à diversificação da matriz ao longo dos anos.

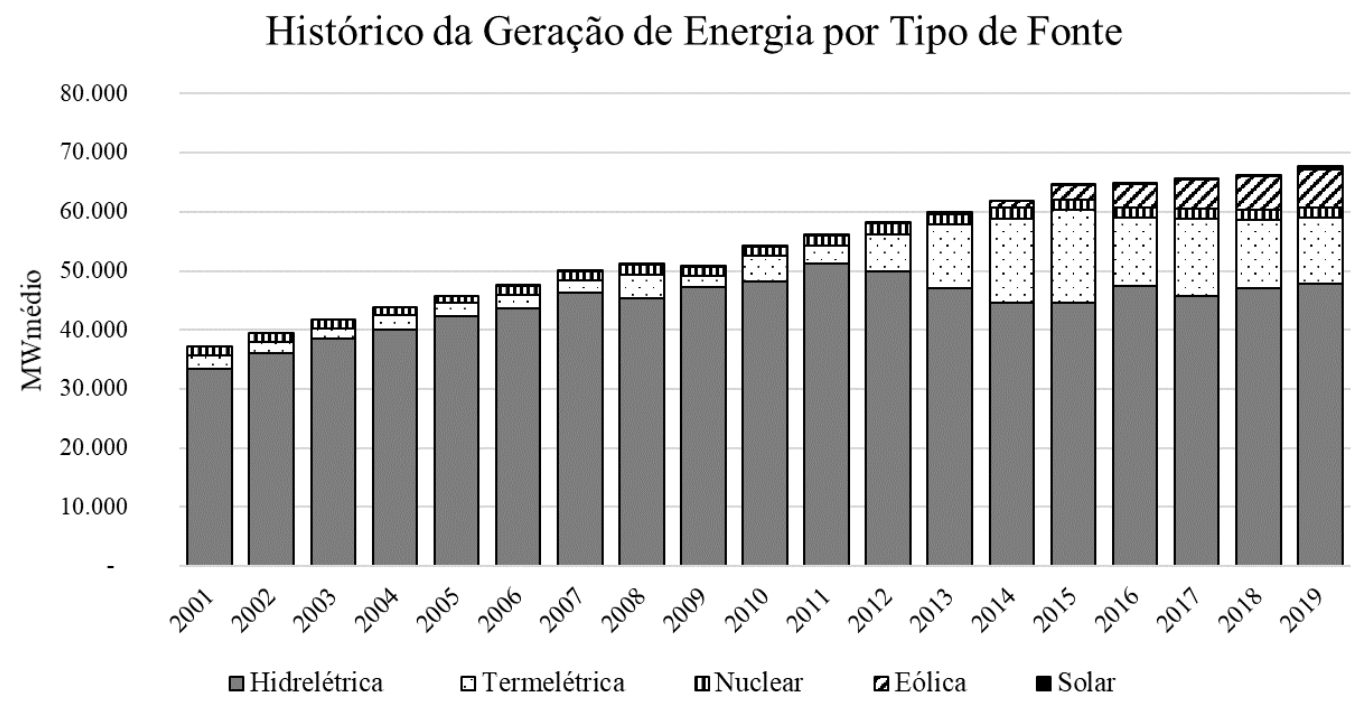

Figura 3: Histórico de Geração de Energia Elétrica no Brasil por Tipo de Fonte.

Fonte: Autora 
À luz desta questão, o próprio governo brasileiro, através da Consulta Pública nº33 de 2017veiculada pelo MME, colocou o tema em discussão, apontando a separação da comercialização de energia elétrica nos produtos Lastro e Energia como uma possível solução.

Desta maneira o governo buscaria associar a confiabilidade ao produto Lastro, remunerando os agentes por sua capacidade de contribuição às necessidades sistêmicas de segurança de fornecimento, enquanto a comercialização do produto energia estaria vinculada à produção real de energia, incluindo seus riscos de volume e preço. Posteriormente, o tema também foi tratado na Consulta Pública nº83 de 2019 veiculada pelo MME, dentro do Comitê de Modernização do Setor Elétrico.

A ideia de um mecanismo para lidar com a questão confiabilidade sistêmica no Brasil não é completamente nova. O conceito da garantia física das usinas está intimamente ligado com a sua capacidade efetiva de contribuir com sua geração dado um critério pré-definido de suprimento. Contudo, tal metodologia não vem se mostrando suficiente para a adequação da expansão da oferta, principalmente no que tange às diferentes características de geração dos diferentes tipos de fonte.

A separação dos produtos Lastro e Energia é, portanto, uma proposta que busca equilibrar a abertura do mercado livre de energia elétrica com uma expansão adequada do parque gerador, permitindo que diferentes atributos, de diferentes tipos de fontes possam ser remunerados conforme sua contribuição para a confiabilidade do sistema, o que permitiria uma melhor financiabilidade dos projetos.

Neste trabalho serão revisados diferentes mecanismos de adequação da expansão contemplados na literatura, assim como a atual proposta do governo brasileiro. Nesse contexto, o presente trabalho propõe a precificação de Lastro e Energia separadamente, mas de forma complementar, de modo que, ao final do processo, a adequação do parque gerador possa ser mantida sem que haja um sobrecusto para o consumidor final.

Para a precificação do preço da Energia foi utilizado um modelo de precificação de contratos futuros que tem como suporte uma parametrização de uma função de "preço de contrato em função da duração e do "delay" de entrega, que utiliza Algoritmos Genéticos para definir parâmetros da função "preço", tendo por base (i) cenários de PLD passados e futuros, (ii) cotações de contratos observadas no mercado livre e (iii) o custo 
médio observado de expansão. A partir desse modelo obtém-se então uma curva de preços para o mercado livre ("Curva Forward").

A precificação do Lastro é realizada então a partir da metodologia de Valuation, onde dada a (i) curva de preços futuros no ACL, (ii) custos de investimento, (iii) custos de operação e manutenção e (iv) custos dos impostos e encargos, busca-se calcular para cada tipo de fonte qual é o valor teto do Lastro necessário ao investidor para que este mantenha uma taxa de retorno adequada para o projeto. Nesse sentido, é realizada a sensibilidade do valor teto do "Lastro" para diferentes níveis de retorno desejados. Observa-se que o valor é considerado 'teto' pois, a análise considera valores conservadores de custo de investimento e operação, além de não considerar benefícios fiscais e subsídios. Portanto, os valores realmente praticados poderiam ser menores em virtude da competição entre os agentes, conforme se observa hoje nos leilões regulados.

Essa forma de cálculo garante que o valor cobrado pelo Lastro corresponderá apenas à diferença entre preço de contrato de venda necessário para recuperar investimentos e custos de operação e o preço que o investidor conseguiria recuperar no mercado livre vendendo o produto "energia" separadamente, garantindo-se que o consumidor final não venha a pagar mais pelo pacote "Lastro/Energia" quando comercializado em separado.

Posteriormente, será feito um estudo de caso, para as fontes hidrelétrica e eólica, da viabilidade econômico-financeira da adoção de contratos com os dois produtos, Lastro e Energia, comercializados separadamente, sob a óptica da Teoria de Opções Reais TOR.

Dados os longos períodos necessários para a amortização de investimentos no setor elétrico, os projetos ficam vulneráveis a variações de preço que podem ser muito relevantes, assim como vulneráveis a mudanças regulatórias. Portanto, utilizar apenas o tradicional Fluxo de Caixa Descontado (FCD) para avaliar este tipo de investimento pode dar margem a uma análise até certo ponto limitada e insuficiente. Como alternativa, podese utilizar a TOR, uma vez que esta permite a consideração de incertezas na análise de investimentos com o suporte de uma modelagem estocástica para as principais variáveis influentes na fixação de uma solução de compromisso entre risco x retorno do capital aplicado na expansão da oferta. Para tanto, serão consideradas como fonte de incerteza a (i) geração hidrelétrica, (ii) geração eólica, (iii) preços do mercado spot e (iv) preços dos contratos de energia. 
Sendo assim, o principal foco deste trabalho estará na avaliação da viabilidade econômico-financeira da migração do tipo de remuneração atual, baseada nos contratos vinculados exclusivamente à produção de Energia ou disponibilidade, para a remuneração baseada na combinação de venda de contratos de Lastro e Energia. As questões jurídicas e regulatórias que permeiam o tema e são também de grande relevância para o equacionamento completo da questão não serão abordadas neste trabalho, contudo certamente podem constituir relevantes pesquisas futuras. 


\section{ARQUITETURA DE MERCADO}

\subsection{Introdução ao Tema}

O termo "arquitetura de mercado" foi primeiramente utilizado no ano 2002, pelo economista Robert Wilson, em Architecture of Power Markets. O documento (P\&D ANEEL, 2014) descreve o termo como:

\footnotetext{
"Arquitetura de mercado se refere, portanto, ao estudo e descrição das características microeconômicas da estrutura do mercado e a como elas impactam o desempenho do mercado. Essa estrutura microeconômica se refere ao arranjo institucional do mercado, à forma pela qual os produtos são agrupados, ao processo de interação dos agentes, e à forma pela qual os produtos são transacionados."
}

A necessidade deste tipo de estudo surgiu após a liberalização e desverticalização de antigos monopólios naturais, com a finalidade de criação de mercados competitivos. Há aproximadamente cinquenta anos, o processo de privatização de empresas estatais e liberalização dos mercados teve início. Comumente, houve uma transição da regulação rígida, até então vigente em setores como eletricidade, comunicação, combustíveis e transportes, para um modelo de mercado competitivo.

Segundo (NEWBERRY, 2001), paradoxalmente, a criação de mercados competitivos e eficientes requer instituições regulatórias sofisticadas, em alguns casos mais do que em outros. Nesse sentido, ao longo das últimas décadas foram se estudando novos mecanismos de mercado que permitissem a introdução da competição em mercados mais complexos.

Alvin E. Roth, vencedor do Prêmio Nobel de Economia de 2012, descreveu em (ROTH, 2008) que existem quatro aspectos importantes que devem ser observados para o funcionamento adequado de um mercado, sendo eles:

- Liquidez

- Congestionamento

- Simplicidade e segurança

- Precaução e monitoramento

A liquidez de mercado está associada à facilidade com que um ativo pode ser convertido em dinheiro, sem que haja perdas efetivas no seu valor. Quando muitos agentes participam do mercado, isto amplia a concorrência no mesmo, proporcionando um ambiente seguro para a compra e venda de ativos, sem que haja preocupação com a 
disponibilidade de oferta e demanda a qualquer momento. Já o conceito de congestionamento está relacionado aos gargalos, físicos ou de informação, presentes nos mercados, que podem limitar o volume de transações, podendo causar influência direta na concorrência e nos preços.

A importância da simplicidade e segurança em um mercado estão ligadas à confiança que diversos agentes participantes podem depositar no mercado, para que realizem suas transações sem receio que a estratégia de terceiros possa afetá-los. Dessa forma, um mercado deve contemplar estímulos para que a atuação dos Agentes permita obter a maior transparência e eficiência possíveis. Quanto à precaução e monitoramento, se referem ao cuidado com que as intervenções nos mercados devem ser realizadas, pois podem causar desequilíbrios nos mesmos. Além disso, mercados devem ser constantemente observados e monitorados, pois, dadas suas características transientes, estes podem necessitar de ajustes e alterações.

Conforme (P\&D ANEEL, 2014), os primeiros esboços de como o setor elétrico poderia ser reestruturado para permitir a concorrência no suprimento de energia foram delineados no livro Markets for Power: An Analysis of Electric Utility Deregulation, de Joskow e Schmalensee (1983). Segundos os autores, o mercado de energia tende a ser ainda mais complexo que outros por conta de suas múltiplas jurisdições, diversidade de agentes envolvidos e necessidade de acoplamento entre a arquitetura de mercado desejada com a operação técnica dos sistemas elétricos.

Deve-se destacar aqui as imperfeições de concorrência às quais o mercado de energia elétrica está sujeito. Como razões, tem-se primeiramente a baixa elasticidade preço-demanda, por conta da alta dependência da sociedade moderna com relação ao consumo de energia elétrica. Em segundo lugar, a presença de restrições de transmissão e de operação, que podem estar vinculadas às mais diversas origens, como física, técnica, hidrológicas, sazonais etc. Em terceiro lugar, tem-se a característica oligopolista da oferta, uma vez que poucas empresas detém um percentual relevante dos ativos de geração do país. E, em quarto e último lugar tem-se as economias de escala e escopo presentes neste mercado.

Do ponto de vista dos princípios da teoria econômica, os mercados competitivos de energia elétrica são por definição incompletos e imperfeitos, conforme explicita Robert Wilson em (WILSON, 2002): 


\begin{abstract}
"Do ponto de vista da teoria econômica padrão, mercados atacados para eletricidade são inerentemente incompletos e competitivamente imperfeitos. Alguma incompletude é inevitável porque a potência é um fluxo (ou campo) de energia que não pode monitorado perfeitamente, e armazenar energia potencial é caro; a maioria das especificidades dos mercados de eletricidade emergem destas duas características. Além disso, os fluxos nas linhas de transmissão são limitados continuamente por questões operacionais e ambientais, e as taxas de rampa dos geradores são limitadas. Mas a principal causa é demanda variável que hoje não conversa com os preços spot flexíveis no nível do varejo, a não ser no caso de grandes consumidores industriais equipados com medidores em tempo real, e mesmo assim, a elasticidade de curto prazo da demanda é notoriamente pequena."1

\section{$[\ldots]$}

"No longo prazo, imperfeições competitivas nos mercados de energia emergem dos mesmos fatores que em outras indústrias, como economias de escala e outras barreiras de entrada, e propriedade oligopolista. A competição é imperfeita no médio prazo porque a produção é capital intensiva e os períodos de construção são longos comparados com as variações nas condições de oferta e demanda. No curto prazo, os preços são inerentemente voláteis e a competição é muitas vezes imperfeita por conta da rigidez técnica pelo lado da oferta, e da demanda inelástica, ...”2
\end{abstract}

Frank Wolak em (WOLAK, 2003), fala de dois principais desafios para o problema do design de mercado no setor elétrico. O primeiro é com relação à extensão com que o setor utilizará mecanismos regulatórios ou mecanismos de mercado para definir os preços para os consumidores. Já o segundo é, como fomentar simultaneamente, que tanto os geradores quanto os varejistas, vendam energia a um preço condizente com a viabilidade financeira de longo prazo da indústria de energia elétrica. Estes desafios envolvem também a decisão de qual a extensão que a participação pública e a participação privada terão em cada segmento da cadeia. Deve-se salientar que não existe um padrão para a organização dos mercados competitivos no setor elétrico. Cada jurisdição tem a liberdade de escolher suas próprias estruturas de regulação e governança.

É de extrema relevância que as microestruturas do mercado de energia elétrica sejam elaboradas com diligência suficiente, para que possam desempenhar funções como a coordenação da expansão, operação e segurança. Para que isto ocorra, a arquitetura de

\footnotetext{
${ }^{1}$ Tradução livre do texto original em inglês: "From the viewpoint of standard economic theory, wholesale markets for electricity are inherently incomplete and imperfectly competitive. Some incompleteness is inevitable because power is a flow (or field) of energy that cannot be monitored perfectly, and storing potential energy is expensive; many of the unique features of electricity markets stem from these two features. Also, flows on transmission lines are constrained continuously by operational limits and environmental factors, and ramping rates of generators are limited. But the primary cause is variable demand that presently is not matched with flexible spot pricing at the retail level, except for large industrial customers equipped with real-time meters, and in any case the short-run elasticity of demand is notoriously small."

${ }^{2}$ Tradução livre do texto original em inglês: "In the long run, imperfect competition in power markets stems from the same factors as in other industries, such as economies of scale and other entry barriers, and oligopolistic ownership. Competition is imperfect in intermediate time frames because production is capital intensive and construction delays are long compared to variations in supply and demand conditions. On short time scales, prices are inherently volatile, and competition is often imperfect because of technical rigidities on the supply side, and inelastic demand, ..."
} 
mercado deve contemplar ao mínimo três estruturas concomitantemente, o mercado a termo, o mercado de curto-prazo e o mercado de serviços ancilares. O mercado a termo é responsável por prover principalmente o funcionamento da coordenação da expansão e adequação da oferta, pois, por se tratar de contratações com maior antecedência, promovem maior estabilidade de receita para os geradores, funcionando como hedge para o fluxo de caixa dos agentes, além de promover também a minimização dos custos de suprimento. Já o mercado de curto-prazo, promove um melhor funcionamento da coordenação da operação, pois permite que ajustes entre a programação diária do despacho com o comprometimento contratual de geradores e consumidores. Por fim, o mercado de serviços ancilares promove uma melhor coordenação da segurança, pois permite que os agentes provedores destes tipos serviços sejam remunerados adequadamente.

Conforme exposto em (P\&D ANEEL, 2014), a organização da estrutura destes mercados pode se dar, não exclusivamente, mas principalmente conforme as opções abaixo:

- Mercado centralizado ou descentralizado

- Tipo de plataforma de negociação

- Mercado aberto ou fechado

- Contratos específicos ou contratos padronizados

- Contratos com compromisso de entrega física ou apenas financeira

- Participação voluntária ou obrigatória

- Precificação com base em lances de oferta ou custos regulados

- Precificação com base em preços uniformes ou discriminatórios

Mercados organizados centralizadamente contam, na maioria das vezes, com a existência de uma plataforma de negociação, onde lances de compra e venda são negociados entre oferta e demanda, conjuntamente. Este tipo de organização implica numa maior padronização de produtos e contratos, o que facilita a competitividade. A centralização pode ocorrer além do nível temporal, podendo ocorrer em nível de serviços e produtos, como custos como de transmissão e serviços ancilares. A ideia do design centralizado é buscar uma melhor otimização dos recursos produtivos, atribuindo a maior parte da responsabilidade da gestão destes ao operador do sistema. 
Os mercados centralizados buscam recapturar os benefícios da operação otimizada que existia à época dos antigos monopólios e empresas verticalizadas.

Já em mercados descentralizados, a negociações entre as partes ocorrem diretamente entre os agentes conforme necessidades bilaterais, proporcionando assim maior flexibilidade de produtos e tipos de comercialização. Mercados descentralizados se apoiam mais nos mecanismos de mercado para uma melhor otimização. Na literatura os mercados centralizados são também conhecidos como integrados e System Operator Commitment. Já o outro extremo, ou seja, os mercados descentralizados, são também conhecidos como unbundled e Self Commitment.

Quanto aos tipos de plataforma de negociação, existem três mais comuns, sendo estas: o mercado balcão; a bolsa e o leilão. O mercado balcão, que possui a estrutura mais simples dentre as três, é voltado usualmente para comercialização de produtos menos líquidos, e serve com espécie de "ponto de encontro", onde ofertantes e compradores podem recorrer quando desejarem comercializar determinado produto. Para a diminuição do nível de risco neste tipo de plataforma, regras simples de comercialização e liquidação são estabelecidas e monitoradas pela instituição que realiza o controle deste mercado balcão. A bolsa, por outro lado, é um tipo de plataforma de comercialização mais padronizada e organizada, proporcionando um ambiente de comercialização com maior liquidez para os produtos nela listados.

Vale salientar que, ambas plataformas, tanto mercado balcão, quanto a bolsa, devem contar com sistema de clearing, ou como conhecido em português, caixa de liquidação, que garante o fiel cumprimento de todas as transações realizadas. A clearing pode ser parte integrante da plataforma de comercialização, ou pode ser uma instituição externa. Conforme (FORTUNA, 2013), seus serviços vão desde o registro das operações e controle das posições, a compensação dos ajustes diários e, ainda, a liquidação física e financeira dos negócios, até a administração de garantias vinculadas às operações.

A plataforma de comercialização do tipo leilão pode ser tão detalhada e organizada quanto a bolsa, se configurando como uma forma alternativa para a realização de transações neste mercado. Contudo, uma diferença fundamental entre os dois é a questão da periodicidade, já que enquanto a bolsa fica aberta initerruptamente, por um longo período do dia, os leilões são realizados em certames periódicos. 
Mercados podem ser abertos ou fechados. Em mercados abertos, algumas informações contratuais, como quantidades e preços são públicas, conferindo assim maior transparência aos mesmos. Já em mercados fechados, as informações contratuais competem apenas aos agentes participantes de cada termo. Quanto aos contratos, estes podem ser específicos ou padronizados. No caso de contratos específicos, as cláusulas negociadas são de conhecimento apenas das partes negociantes, sendo qualquer ajuste aos termos já pactuados, feito apenas mediante negociação entre as partes ou litígio. Já os contratos padronizados, que são conhecidos também como títulos ou certificados, podem ser comercializados entre quaisquer agentes participantes daquele mercado, possibilitando inclusive a formação de um mercado secundário. Como resultado, contratos padronizados acabam por possibilitar uma maior flexibilidade aos agentes, pois estes podem ajustar suas posições comercializando estes papéis, sem a necessidade exclusiva de negociação bilateral, como no caso dos contratos específicos.

Os contratos também podem assumir compromissos de entrega física ou entrega apenas financeira. Contratos com compromisso de entrega física são mais aderentes às questões operacionais do setor, todavia acabam por limitar uma possível padronização, o que, como citado anteriormente, facilita a comercialização dos mesmos e permite maior liquidez. Portanto, quando os contratos possuem entrega apenas financeira, é importante que a regulação se atente à adequação dos produtos às competências de responsabilidade do mercado.

A participação no mercado pode ser definida tanto como voluntária, quanto como obrigatória. A faculdade da participação no mercado tende a gerar eficiência, pois demandará aprimoramentos constantes para que os agentes participem efetivamente daquele mercado e para que este performe como previamente imaginado. Por outro lado, mercados com participação obrigatória tem como benefício um melhor tratamento de externalidades.

Conforme definido em (P\&D ANEEL, 2014), externalidades são os impactos sobre terceiros ocasionados por uma determinada transação econômica, podendo estes serem positivos ou negativos. Na literatura sobre design de mercado, o tratamento de externalidades é considerado como um dos principais dilemas. Conforme a literatura econômica, o tratamento de externalidades possui duas abordagens clássicas, a de Cecil Pigou e a de Ronald Coase. 
As ideais de Cecil Pigou são expostas em seu livro The Economics of Welfare (1920). Conforme sua abordagem, o custo social das externalidades poderia ser cobrado através de uma taxa, ou imposto (conhecido como o "imposto de Pigou"), o que levaria a um novo equilíbrio de mercado onde a maximização do bem-estar social estaria garantida. Ou seja, o tratamento da externalidade é realizado através de uma intervenção no mercado. Já Ronald Coase, em seu artigo The Problem of Social Costs (1960), advoga que a solução das externalidades não necessita necessariamente de intervenção, podendo os agentes do mercado obterem resultados através de negociação espontânea, quando previsíveis os resultados do sistema judiciário e garantidos os direitos de propriedade. Vale ressaltar que a proposta de Coase também busca garantir a maximização do bemestar social.

Em (DOREN, 2000), o autor comenta o dilema do tratamento de externalidades no setor elétrico conforme as duas abordagens clássicas da literatura econômica, principalmente no ramo da transmissão. $\mathrm{O}$ autor aponta que uma resolução para a discussão pode vir dos históricos de dados dos mercados Pennsylvania-New JerseyMaryland (PJM) e da Califórnia, uma vez que o PJM está mais próximo do tratamento sugerido por Pigou, enquanto no mercado californiano está mais próximo do tratamento sugerido por Coase. No caso da abordagem com Pigou, as externalidades oriundas sistema de transmissão, resultantes dos limites físico-operacionais do sistema, são calculadas através de modelos computacionais sob a óptica dos preços marginais locacionais, sendo seus custos incorporados aos preços de energia. Já a abordagem sugerida por Coase, o tratamento das externalidades envolve a definição dos direitos de propriedade sobre os ativos de transmissão.

Com relação às possibilidades de precificação no mercado de eletricidade, podese optar por custos regulados ou por lances de oferta. A precificação por lances de oferta permite que os preços praticados reflitam os reais custos dos agentes naquele momento específico. Não obstante, conforme (P\&D ANEEL, 2014), a desvantagem da precificação com bases em lances de oferta é que esta pode ser explorada pelos agentes quando os mesmos executam ações oportunistas visando a elevar os preços do sistema, o que se denomina gaming. Por outro lado, a precificação por custos regulados, apesar de reduzir os riscos do gaming, não necessariamente o extingue, uma vez que existe assimetria de informações entre os agentes e o regulador. 
A precificação no mercado de energia elétrica também pode ser dividida em preços uniformes e preços discriminatórios. Quando os agentes comercializam um mesmo produto em um mesmo período, caso todos os participantes recebam o mesmo valor pelo produto, que é o preço marginal ofertado (i.e. o maior preço ofertado), os preços neste mercado são uniformes. Já, quando cada agente recebe o valor do seu próprio lance pelo produto, os preços praticados são discriminatórios. Os preços uniformes fomentam estratégias mais arrojadas por parte dos agentes, enquanto os preços discriminatórios fomentam estratégias mais cautelosas.

Nas seções a seguir serão discutidos mais detalhadamente temas referentes à arquitetura de mercado e pertinentes para a elaboração deste trabalho.

\title{
2.2. Adequação da Oferta
}

Nas décadas passadas, muitos países implementaram uma liberalização de seus mercados de energia elétrica, buscando, principalmente nos segmentos de geração e comercialização, a introdução da concorrência. Isso porque, idealmente neste ambiente, a sinalização de preços dos produtos leva os agentes participantes do mercado a tomarem decisões mais eficientes. Conforme Joskow em Lessons Learned from Electricity Market Liberalization (2008) o objetivo da reforma institucional era trazer maiores benefícios de longo prazo para a sociedade:

\begin{abstract}
"Os benefícios seriam percebidos com base na crença em que mercados atacados de energia competitivos promovem melhores incentivos no controle de custos de construção e operação de plantas novas e existentes de geração, no estímulo da inovação em tecnologias de suprimento de energia, no estímulo aos operadores de rede para que proporcionem níveis apropriados de qualidade de serviço e no direcionamento dos riscos de escolhas de tecnologias, de custos de construção e de "erros" de operação aos geradores, afastando-os assim dos consumidores."3
\end{abstract}

Todavia, a utilização do termo liberalização traz a falsa ideia de que houve uma flexibilização da regulação, sendo que, conforme (RODILLA e BATLLE, 2012), existe um paradoxo neste processo:

“...a necessidade da intervenção do regulador para complementar o mercado de eletricidade, com o intuito de garantir o suprimento, é uma boa

\footnotetext{
${ }^{3}$ Tradução livre do texto original em inglês: "The benefits are to be realized by relying on competitive wholesale markets for power to provide better incentives for controlling construction and operating costs of new and existing generating capacity, to encourage innovation in power supply technologies, to provide incentives for network operators to provide appropriate levels of service quality, and to shift the risks of technology choice, construction cost and operating "mistakes" to suppliers and away from consumers."
} 
ilustração deste paradoxo: a desregulamentação de sistemas elétricos acabou por acentuar a necessidade crucial em reforçar a regulação."

A existência de um mercado competitivo nos segmentos de geração e comercialização de energia elétrica aumenta a responsabilidade da regulação em fornecer os incentivos adequados para que se mantenham a adequação e segurança do suprimento, conceitos que juntos compõe a confiabilidade do sistema, o que é considerado um bem público.

Vale ressaltar aqui a diferença entre o conceito de adequação e segurança de suprimento. A adequação é proporcionada por todos os agentes e/ou instituições do setor com o intuito de prover um sistema estaticamente estável. Já a segurança do suprimento tem como responsável o operador do sistema e é proporcionada principalmente no curto prazo através da coordenação da geração e da transmissão no atendimento da demanda. Usualmente, esta coordenação é realizada pelo próprio operador do sistema, comumente em escala horária, de forma a tornar o sistema dinamicamente confiável.

A adequação da oferta deve promover um nível ótimo de capacidade no equilíbrio, conforme os critérios de confiabilidade pré-estabelecidos. Além disso, os mecanismos de incentivo à construção e novas usinas devem evitar a ocorrência de ciclos de investimento, o que pode levar a períodos de sub/sobre oferta. Conforme exposto em (VRIES e HEIJNEN, 2007), o mercado de geração de energia elétrica é um ambiente propício para ciclos de investimento, tanto por ser capital-intensivo, quanto pelo longo tempo de construção necessário para que novas plantas fiquem prontas.

A adequação da geração deve promover também que a combinação das fontes que compõe, e que venham a compor o parque gerador, seja ótima. Ou seja, o mix de geração deve ser tal que diversifique os riscos de operação e que aproveite a sinergia entre os diferentes tipos de fonte, tanto na escala de temporal, quanto espacial.

Destaca-se aqui o impacto da escolha da estrutura de mercado e sua influência na evolução dele. Em (HUNTINGTON e CHAO, 1998), os autores discutem, com base num workshop realizado na Universidade de Stanford em 1997, a correlação entre o design de mercado e a evolução tecnológica do setor de energia elétrica.

\footnotetext{
${ }^{4}$ Tradução livre do texto original em inglês: “... the need for the regulator's intervention to complement the electricity market in order to guarantee the supply, is a good illustration of this paradox: the deregulation in electricity systems has accentuated the crucial need for reinforcing the regulation."
} 
Segundo os autores, deve-se observar que a escolha de uma determinada estrutura de mercado acaba por moldar a evolução dele. Portanto, as escolhas realizadas no presente devem atender não só as atuais necessidades do mercado, mas também as expectativas futuras que se tem com relação a este.

Desde o início da liberalização dos mercados ao redor do mundo, havia a preocupação de que esta nova estrutura permitisse uma optimização da operação, planejamento e investimentos. Como resposta, diversos mecanismos de capacidade foram criados em diferentes mercados para garantir a adequação do volume de geração de energia.

Segundo (CHATTOPADHYAY e ALPCAN, 2016), existem basicamente dois tipos de mercados para comercialização de energia elétrica, os mercados que comercializam apenas energia, conhecidos como Energy-Only Markets, e o mercados que comercializam energia e capacidade, conhecidos como Capacity-Energy Markets. Como descrito em (VRIES e HEIJNEN, 2007), nos mercados Energy-Only não existem instrumentos regulatórios que estimulem o investimento em capacidade; sendo assim, os preços de energia são o único driver para realização de novos investimentos. Ou seja, nestes mercados, o mercado spot é fundamental para a gestão, tanto da parte do portfólio descontratado dos geradores e consumidores, quanto como para os preços dos contratos de mais longo prazo firmados. Austrália, Nova Zelândia e Singapura são exemplos de países que operam com sob este modelo de mercado. Já os mercados Capacity-Energy promovem pagamentos separados para disponibilidade de capacidade e para a energia comercializada.

Apesar de os mecanismos de capacidade estarem presentes em muitos mercados, importantes referências da literatura acadêmica considerarem que tais mecanismos criem distorções nos mercados nos quais estão inseridos, conforme aponta (ERBACH, 2017).

$\mathrm{Na}$ Europa, muitos países faziam e ainda fazem a adoção de mecanismos de capacidade. Contudo, conforme apontado por (ERBACH, 2017), em 2016, a Comissão de Energia Limpa para todos os Europeus inclui em suas propostas a revisão das regras de adequação de suprimento e definiu princípios para os mecanismos de capacidade. Nesse contexto, inclusive, o Parlamento Europeu apoiou a criação de mercado de capacidade entre países, pontuando, contudo, que deveriam ser usados apenas em condições específicas. 
Dentro dos conceitos de mecanismos de capacidade, (ACER, 2013) pontua como tipos de mecanismo de capacidade (i) reservas estratégicas, (ii) obrigações de capacidade; (iii) leilões de capacidade; (iv) opções de confiabilidade e (v) pagamentos por capacidade.

As reservas estratégicas do sistema (strategic reserves), utilizadas por países como Alemanha, Bélgica, Polônia e Suíça, são um mecanismo no qual uma agência central contrata um montante de energia com anos de antecedência, sendo essas plantas proibidas de participarem dos mercados de energia elétrica.

Na Inglaterra, são realizados leilões de capacidade para garantir a segurança do suprimento. Além dos leilões de capacidade, em 2013, o governo inglês instituiu os mecanismos de Supplemental Balancing Reserve (SBR) e Demand Side Balancing Reserve (DSBR). Mais detalhes podem ser encontrados em (OFGEM, 2015).

A França, por sua vez, conta com um mecanismo de obrigação de capacidade (capacity obligation), que é uma obrigação aos grandes consumidores ou geradores de contratar um montante de capacidade de acordo com suas expectativas de consumo futuras, adicionados de uma margem de reserva.

Países como Polônia, Portugal, Espanha e Irlanda contam com mecanismo de pagamento por capacidade (capacity payments), onde taxas pré-determinadas pelo regulador são pagas às plantas fornecedoras de capacidade, que também podem continuar participando do mercado de energia.

Conforme (OREN, 2000), nos Estados Unidos mercados como PJM NYPP e New England adotaram o mecanismo de Planning Reserves Requirement, onde supridores de potência devem ter contratos com geradores para níveis pré-definidos de capacidade acima de seus picos de demanda, em certos períodos.

\subsection{Missing-Money Problem}

Após a experiência vivenciada por alguns países, posteriormente à abertura de seus mercados de energia, começou-se a questionar se os preços de energia eram um driver suficiente e adequado para a sinalização da necessidade de expansão da oferta. Para tal questionamento, temos como argumento os seguintes tópicos:

- Preços artificiais praticados no mercado de curto prazo (e.g. PLD "piso" e "teto"), que limitam o pagamento aos geradores em momentos de escassez; 
- Despachos inflexíveis como forma de manter a confiabilidade energética;

- Despachos fora da ordem de mérito econômico;

- Volatilidade de preços que levam à dificuldade com relação ao financiamento de novos projetos.

A adoção de preços teto é realizada tanto para limitar práticas anticompetitivas de geradores em mercados com despacho descentralizado, quanto para limitar perdas dos consumidores de energia em momentos de escassez.

Quando o preço de energia praticado no mercado reflete exatamente o custo de despacho das fontes, cria-se, em tese, uma sinalização adequada para a expansão, pois fica claro para o investidor qual o custo real que a demanda está disposta a pagar para a aquisição do próximo MW e qual a frequência com que essa necessidade ocorre. Ambas as variáveis possibilitariam o investidor dimensionar adequadamente o retorno necessário para recuperar tanto o investimento de capital quanto seus custos operacionais.

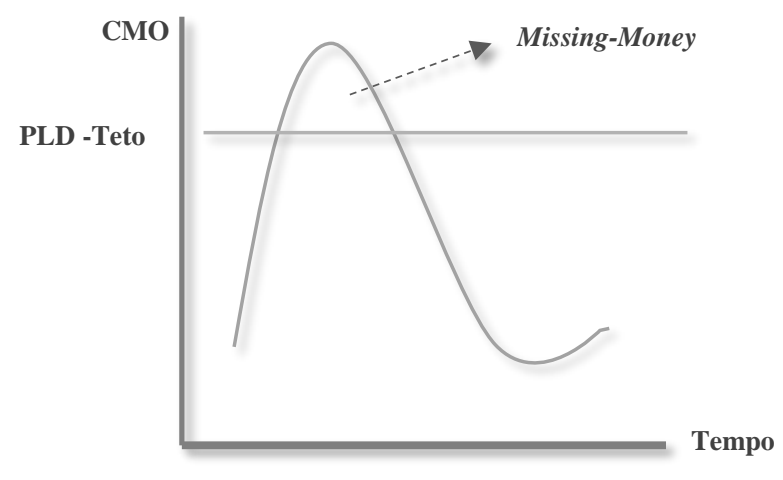

Figura 4: Ilustração do Missing Money Problem.

Fonte: Autora

Contudo, assim como discutido em (CRAMTON e SOFT, 2006), a prática de preços tetos de energia elétrica limita o uso do preço do mercado no atacado, ou preço "spot", como uma sinalização para investimentos em plantas de geração de maior custo e que poderiam atuar principalmente no atendimento à demanda de ponta. A essa distorção causada pelo preço-teto se dá o nome na literatura de Missing-Money Problem.

Conforme ilustra a figura acima, no caso do sistema brasileiro, quando o PLD, que remunera o mercado efetivamente, é menor que o CMO, os agentes de geração que proveram a energia mais cara que o PLD teto naquele período não foram adequadamente remunerados, dado o serviço que prestaram no momento de escassez. 
A esse volume de dinheiro que não gerou uma receita adicional ao gerador se dá o nome de "missing-money". Justamente, quando havia escassez e o gerador "de-ponta" atuou, não recebeu a mais por isto.

No Brasil, a argumento para a utilização de preços-teto no mercado de energia deriva principalmente das características específicas do seu setor elétrico. Como as condições hidrológicas possuem extrema influência sobre a formação de preços no MCP e o modelo de despacho do parque de geração brasileiro é o mesmo que o modelo de formação de preços, o preço de energia elétrica no Brasil reflete não só o equilíbrio entre a oferta e demanda de energia, mas também as condições hidrológicas nas quais o país se encontra.

Assim, para que mercados que comercializem apenas energia funcionem, é necessário que os preço-teto, se existirem, reflitam o custo da escassez da energia, o que seria no Brasil poderia ser mensurado pelo Custo do Déficit ou pelo Custo de Interrupção. Contudo, a utilização desse mecanismo em mercados menos maduros, como o caso do mercado brasileiro, pode elevar demasiadamente os riscos de ruptura de equilíbrio financeiro dos agentes no mercado de curto prazo, sem necessariamente passar confiança ao investidor que o investimento possa ser realizado e que venha a ser efetivamente remunerado. A isso, soma-se a questão de que os preços no Brasil refletem também as condições hidrológicas momentâneas, o que dificultaria ainda mais a decisão do investidor com base nos preços de mercado, que apresentam muita volatilidade e não iriam proporcionar um fluxo de caixa com a regularidade exigida para uma adequada administração financeira por parte do empreendedor.

Neste contexto, a razão para a utilização de preços-teto neste mercado estaria muito mais ligada à estabilidade do mercado de curto-prazo, o qual poderia sofrer problemas de solvência caso os preços permanecessem demasiado elevados por conta de condições hidrológicas, do que ao controle de práticas anticompetitivas.

Além do problema do Missing-Money, o preço da energia pode não ser suficiente para representar o real custo da eletricidade em razão de subsídios, além de outros serviços prestados por alguns tipos de geradores que, muitas vezes não são adequadamente remunerados, por se tratar de externalidades relacionadas aos diferentes atributos de cada fonte energética. 


\section{PROBLEMÁTICA DO SEB}

\subsection{Uma Breve História do SEB Sob a Óptica da Expansão}

As companhias de energia elétrica ingressaram no Brasil por volta do início do século XX, durante o período da República-Velha. O capital era majoritariamente estrangeiro e não havia qualquer planejamento centralizado ou política de expansão. Empresas privadas vinham do exterior investir basicamente em geração de energia no país, atendendo principalmente à centros de consumo regionais através de pequenas usinas. A demanda por energia vinha majoritariamente dos serviços de iluminação e transporte, uma vez que a base econômica do país era agroexportadora.

O Código de Águas, promulgado em 1934, transferiu à União o patrimônio de todos os recursos hídricos nacionais, atribuindo a esta o poder de conceder ou autorizar a geração de energia através da hidroeletricidade ou demais aproveitamentos com finalidade industrial. Tal poder estava até então nas mãos dos estados e municípios, que podiam negociar livremente contratos e autorizações com as empresas privadas.

Em 1939, foi criado o Conselho Nacional de Água e Energia Elétrica (CNAEE), primeiro órgão nacional com finalidade exclusiva para o estudo de questões ligadas à utilização de recursos hídricos e energia elétrica. Além disso, cabia-lhe organizar os planos de interligação de usinas elétricas na forma estabelecida pelo decreto que criou o Código de Águas (Decreto $\mathrm{n}^{\mathrm{o}}$ 24.643, de 10 de julho de 1934), e organizar a regulamentação deste decreto, bem como das demais leis referentes à utilização dos recursos hidráulicos e da energia elétrica no país. O órgão desempenhou um papel importante numa sociedade que tinha, até então, $90 \%$ da capacidade instalada controlado pelas empresas estrangeiras Brazilian Traction Light \& Power Co e American \& Foreign Power (Amforp).

As empresas estrangeiras ainda experimentaram parte do processo de industrialização do país, durante o Estado Novo (1937-1946), quando houve uma alteração do perfil de demanda por energia elétrica no país, que crescia em volumes muito maiores que nas décadas passadas. Com o passar dos anos o Estado foi aumentando sua participação no setor elétrico, podendo-se exemplificar com a criação da Companhia Hidrelétrica do São Francisco (Chesf) em 1945, a criação da Central Elétrica de Furnas em 1957 e a criação da Hidrelétrica do Vale do Paraíba em 1961. 
Nos anos 60 e 70, os setores de geração, transmissão e distribuição de energia já eram dominados pelo setor público. O financiamento do capital necessário para os novos investimentos também era majoritariamente público, fato que possibilitou o desenvolvimento do importantes obras de transmissão, como também obras de geração de grande escala, dentre as quais se pode citar as maiores usinas hidrelétricas incorporadas ao sistema interligado do País até recentemente, Itaipu e Tucuruí. A distribuição, que também estava sob controle do governo, passou para um regime tarifário com base no custo de serviço, modelo muito utilizado em outros países nesse mesmo período.

No início dos anos 60, o consórcio Canambra foi contratado para realizar os primeiros estudos de planejamento de longo-prazo do sistema elétrico brasileiro e o inventário do potencial hidrelétrico do país. Foi depois de 1967, quando foi inserida a Diretoria de Planejamento e Engenharia (DPE), que a Eletrobrás passou a exercer a liderança das atividades de planejamento. (MERCEDES, RICO e POZZO, 2015)

Conforme expõe Goldenberg e Prado em (GOLDENBERG e PRADO, 2003):

\begin{abstract}
"O planejamento do setor elétrico iniciava-se com o estudo regionalizado do mercado futuro de energia elétrica, considerando as características do consumo e da demanda. Os resultados dessa etapa alimentavam estudos energéticos, simuladores de um conjunto de usinas que poderiam ser construídas a um custo mínimo para a sociedade. Essas alternativas de construção de usinas, juntamente com a distribuição dos mercados pelos diversos centros de consumo, serviam de base ao planejamento das linhas de transmissão necessárias."

"O resultado de cada ciclo anual de planejamento era consolidado no Plano Decenal de Expansão do Setor Elétrico.”
\end{abstract}

A Lei 5.899, de 1973, conhecida como Lei de Itaipu, reforçou as ações da Eletrobrás como coordenadora do planejamento e da operação do sistema brasileiro. (MERCEDES, RICO e POZZO, 2015). Foram criados também o Grupo Coordenador de Operação Interligada (GCOI) e de Coordenação do Planejamento do Sistema (GCPS), com a finalidade de otimizar a utilização dos troncos de interligação existentes.

A crise do sistema teve início por volta da década de 80, na mesma época em que os parâmetros do modelo de Programação Dinâmica Estocástica (PDE), desenvolvido pela Eletrobrás e o Centro de Pesquisa de Energia Elétrica (Cepel), puderam começar a ser utilizados para a operação e planejamento do setor elétrico brasileiro. 


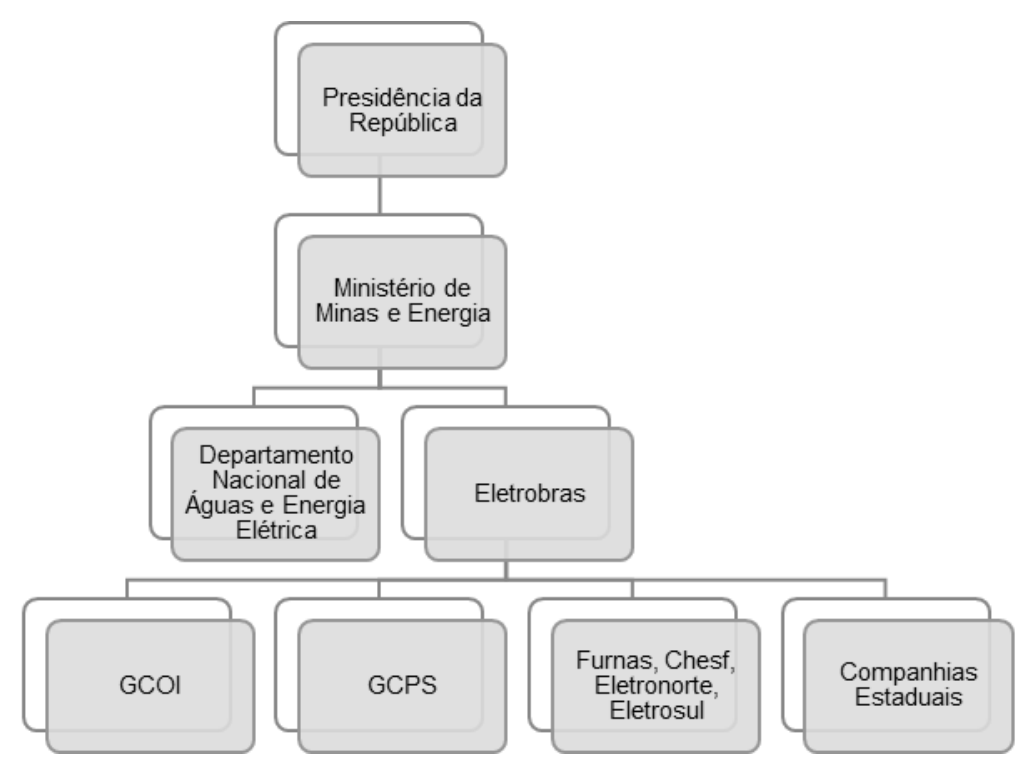

Figura 5: Estrutura do Planejamento do Setor Elétrico Brasileiro ao Final dos Anos 80

Fonte: Autora

Com o segundo choque do petróleo, os problemas com a balança de pagamentos e a elevação da taxa de juros americana, que levou à uma elevação do custo da dívida externa brasileira, o governo já não conseguia mais suportar sozinho os planos de investimento.

Devido à crise, as empresas tiveram que partir em busca de capital externo para financiar seus novos projetos, o que encareceu o custo do dinheiro e levou a uma forte redução de investimentos no setor. Além disso, as tarifas de energia elétrica foram utilizadas na época como forma de contenção para a inflação, o que desvirtuou o modelo de serviço pelo custo, utilizado até então, e desestimulou ainda mais os investimentos. Todos estes elementos levaram a um questionamento sobre a qualidade do planejamento da expansão centralizado.

Nessa época, os estudos de planejamento da expansão começaram a ser feitos pelo Grupo Coordenador do Planejamento de Sistema Elétrico (GCPS), criado em 1980. Este era um órgão colegiado coordenando pela Eletrobrás e contava com a participação de todas as empresas do setor elétrico, fossem estas da inciativa pública ou privada. Apesar do planejamento, na época, possuir um caráter determinativo, seu processo de elaboração era participativo e todas as empresas participantes tinham acesso aos dados utilizados. Foi ao longo da década de 80 que o GCPS começou a considerar a programação estocástica nos estudos de expansão. O grupo ficou responsável pelo planejamento e expansão até 1995. 
Nos anos 90 observou-se a globalização das economias e formação dos blocos econômicos regionais de comércio. Conforme expõe Goldenberg e Prado em (GOLDENBERG e PRADO, 2003):

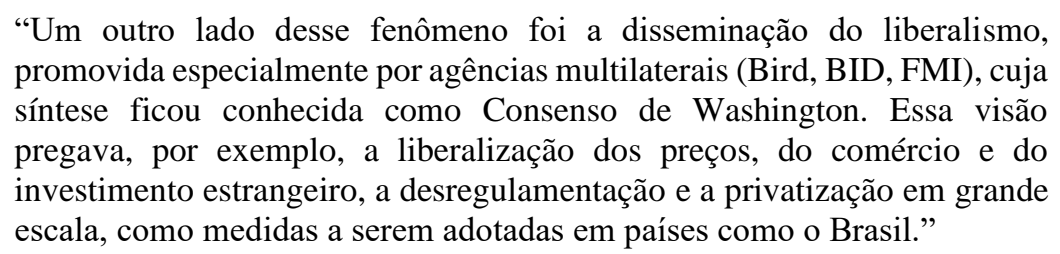

Todo este contexto levou o país à tentativa de alterar o modelo estrutural de Empresas de Ciclo Completo (ECC), vigente naquele momento.

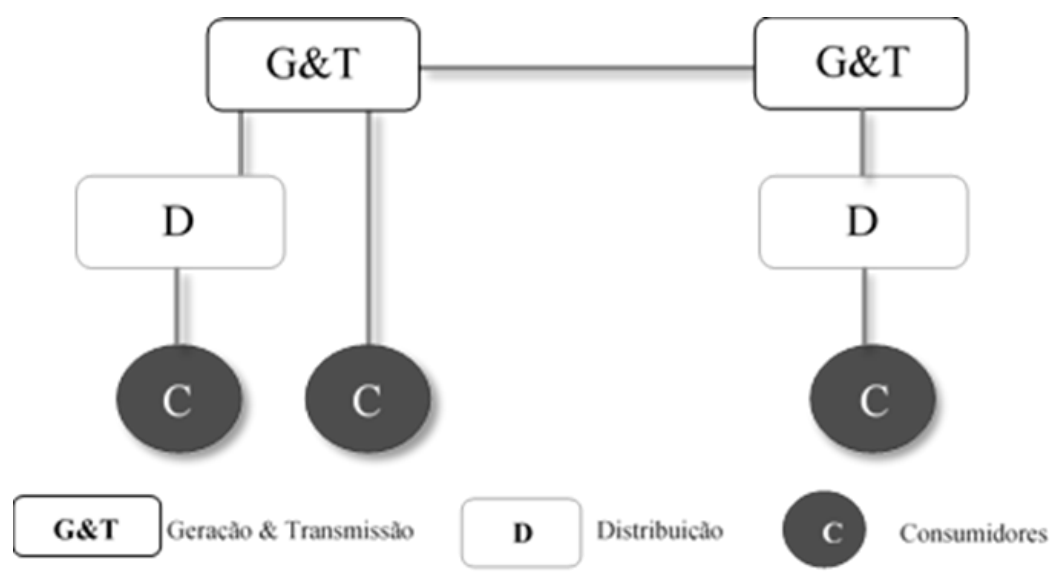

Figura 6: Estrutura Integrada de ECCs

Fonte: Autora

Em 1992, o então Presidente da República Fernando Color de Melo, publicou o Plano Nacional de Desestatização (PND), o qual buscava as privatizações no país, começando pelo setor elétrico. Posteriormente, a Lei 8.361 de 1993 e o Decreto 1.024 de 1994, promulgados durante o governo Itamar Franco, criaram a base legislativa para a venda das estatais.

No ano de 1995, durante o governo do presidente Fernando Henrique Cardoso, houve a criação do Conselho Nacional de Desestatização (CND) e a promulgação da Lei 9.074. Tal lei criou a figura do PIE e do consumidor livre, ambos de extrema importância para o estabelecimento da competição no mercado. Além disso, a Lei 8.987 de 1995 regulamentou o regime de concessões e permissão de prestação de serviços públicos. 
Vale ressaltar que a década de 90 também sinalizava uma retomada do aumento da demanda por energia elétrica, motivada pela estabilidade econômica, devido ao plano real. (SILVA, 2008) Nesse contexto, em meados da década de 90, o governo criou o projeto de Reforma do Setor Elétrico Brasileiro (Re-SEB), que teve por finalidade implementar a competição nos setores de geração e comercialização e manter a neutralidade comercial nos setores de transmissão e distribuição, considerados monopólios naturais. Como consequência, houve uma desverticalização do setor com a finalidade de atrair capital privado para a expansão da geração, dada a garantia de acesso isonômico aos sistemas de transmissão e distribuição. A criação da ANEEL, do ONS e do MAE, foi fruto deste projeto. Em 1996, foi contratada a consultoria inglesa Coopers \& Lybrand para auxiliar no processo de reestruturação.

Conforme expõe Goldenberg e Prado em (GOLDENBERG e PRADO, 2003):

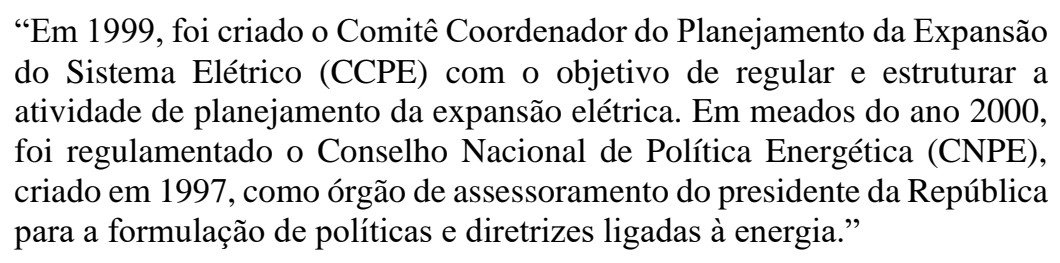

Enquanto isso, a operação passaria a ser realizada pelo ONS, substituindo as antigas atribuições do GCOI.

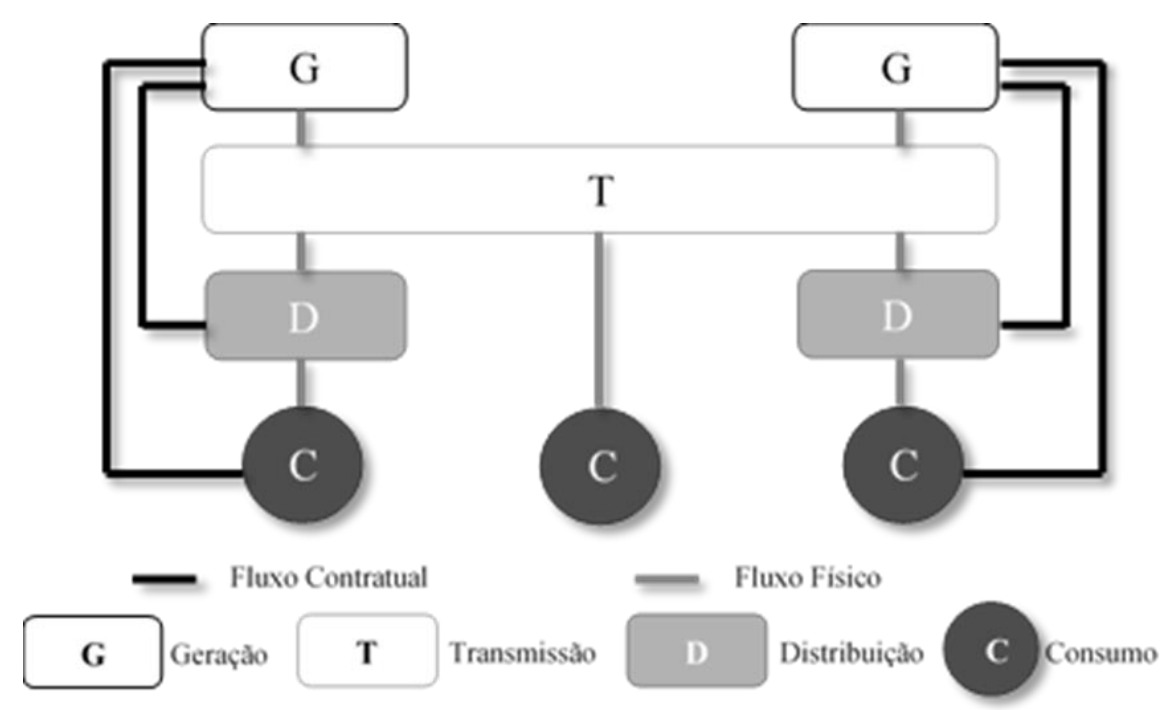

Figura 7: Estrutura de mercado balizadora do modelo Re-seb

Fonte: Autora 
No CCPE, por conta do novo modelo liberal do setor, o fluxo de informações que era divulgado e compartilhado entre os agentes públicos e privados, passou a ficar concentrado nas mãos do governo por serem considerados de importância estratégica comercial. Sendo assim, o planejamento deixou para traz seu caráter normativo e passou a ser indicativo. Neste momento, o carácter liberal do mercado começou a exercer com mais força sua função. O planejamento seria mínimo para dar as diretrizes necessárias da expansão, porém as decisões de investimento seriam tomadas exclusivamente pelos investidores com base em suas premissas técnico econômicas.

A falta de um coordenador central, papel antes exercido pela Eletrobrás, associado às condições hidrológicas ruins levaram o setor à uma crise inusitada. Os Programa de Geração Emergencial e Programa Prioritário Termelétrico, implantados pelo governo em 1999 e 2000, com o intuito de expandir a capacidade instalada de forma célere, não foram suficientes para equacionar a questão. Em junho de 2001, foi decretado o racionamento de energia elétrica, aumentando a desconfiança na capacidade do governo de gerenciar a crise no setor elétrico e no modelo liberal vigente. Ficou evidente, nas explicações fornecidas pelo governo, que o racionamento poderia ter sido evitado em grande parte se os planos de investimentos sistêmicos sugeridos pela Eletrobrás tivessem sido seguidos. Ou seja, a falta de coordenação e gerenciamento da expansão da geração naquele momento, associados à um modelo vigente que não contemplava características específicas do sistema brasileiro, majoritariamente hidrelétrico, levou a instauração de uma crise sistêmica e institucional sem precedentes no país.

Como tentativas para o equacionamento da questão, o governo liberou adiantamentos do BNDES para recomposição tarifária e criou a Comercializadora Brasileira de Energia Emergencial (CBEE) para evitar futuros racionamentos, ambas decisões extremamente custosas para a economia brasileira. Segundo (GOLDENBERG e PRADO, 2003), ambas medidas chegaram a custar R $\$ 20$ bilhões para o país, a preços de 2003.

Após o racionamento e a mudança nos padrões de consumo da população, que se tornaram mais eficientes. Como consequência, houve uma sobra sistêmica de energia, que levou à uma grande volatilidade de preços no MAE. Com os preços baixos, devido à sobra, novos investimentos ficaram inviáveis através da sinalização de preços por oferta e demanda, levando o governo a instituir mudanças regulatórias importantes no modelo setorial vigente. 
Em 2003, durante o governo Lula e sob a gestão de Dilma Rousseff, algumas mudanças no então modelo vigente são implementadas com o intuito de aprimoramento, fazendo com que o planejamento da expansão passasse a ser realizado de forma satisfatória. Nesse sentido, foram criados os LEN, que proporcionariam uma expansão planejada pelo governo, em caráter determinativo, no ACR, através da competição promovida por este mecanismo, sendo a demanda das distribuidoras determinadas individualmente. Adicionado à isto, foi permitido que os PIE comercializassem energia, tanto no ACL, quanto no ACR, criados pela Lei 10.848 de 2004.

\subsection{Modelo de comercialização de energia vigente}

Atualmente, no Brasil, os produtos Lastro e energia são comercializados juntos através dos CCEARs, resultantes da concorrência dos leilões realizados pelo governo, e através dos CCVEEs, produto das comercializações realizadas no ACL. Nessa arquitetura de mercado, a comercialização conjunta dos produtos Lastro e energia no Brasil foi aplicada no modelo setorial, criado no início do século XXI, com o intuito de garantir maior simplicidade ao processo de contratação de energia e melhorar as condições de financiabilidade dos projetos.

Vale lembrar que, anteriormente à criação do novo modelo setorial, o país havia passado por um racionamento de energia elétrica bastante profundo. Como consequência, o governo brasileiro precisava garantir que a expansão do parque gerador, sustentada em grande parte pelo setor privado, conferisse a adequação de suprimento necessária para evitar um novo evento como aquele.

Pode-se encontrar o conceito de Lastro, conforme reconhecido hoje pelo governo brasileiro, no Decreto 5.163 de 30 de julho de 2004 (alterado pelo Decreto $\mathrm{n}^{\circ} 8.828$ de 2016). O Art. $2^{\circ}$ disciplina in verbis “Art. $2^{\circ}$ - Na comercialização de energia elétrica de que trata este Decreto deverão ser obedecidas, dentre outras, as seguintes condições: I os agentes vendedores deverão apresentar Lastro para a venda de energia para garantir cem por cento de seus contratos; (Redação dada pelo Decreto n 8.828, de 2016)"; e no “§ $1^{\circ}$ - O Lastro para a venda de que trata o inciso I do caput será constituído pela garantia física proporcionada por empreendimento de geração própria ou de terceiros, neste caso, mediante contratos de compra de energia. (Redação dada pelo Decreto $\mathrm{n}^{\circ}$ 8.828, de 2016)". 
Como se pode observar, o conceito de Lastro reconhecido pelo SEB atualmente, está intrinsecamente ligado ao conceito de garantia física. Para os geradores, a garantia física representa o volume máximo, em MW médios, que o gerador poderá comercializar referente à um empreendimento específico. Já, para os agentes consumidores (incluindo as distribuidoras), fica definido em decreto que estes devem possuir Lastro, através de contratos, para honrar a totalidade de seu consumo. Vale ressaltar que o Lastro é o volume verificado no centro de gravidade ${ }^{5}$, enquanto a garantia física é o volume em MW médios de energia, atribuído pelo MME a uma usina, e verificado na barra de geração.

Enquanto o Lastro representa o que seria a real capacidade de suprimento de energia do SIN, os contratos de energia representam um hedge, que os agentes participantes do SEB podem comercializar como forma de proteger suas posições, em volume e preço, com relação à liquidação do MCP. Ou seja, os agentes geradores podem se proteger de possível queda futura de preços, enquanto os agentes consumidores podem se proteger de uma eventual futura elevação de preços. Tal mecanismo, também está previsto no Decreto $n^{\circ} 5.163$ de 2004.

A figura a seguir ilustra a estrutura contratual vigente no SEB, com suas respectivas funcionalidades:

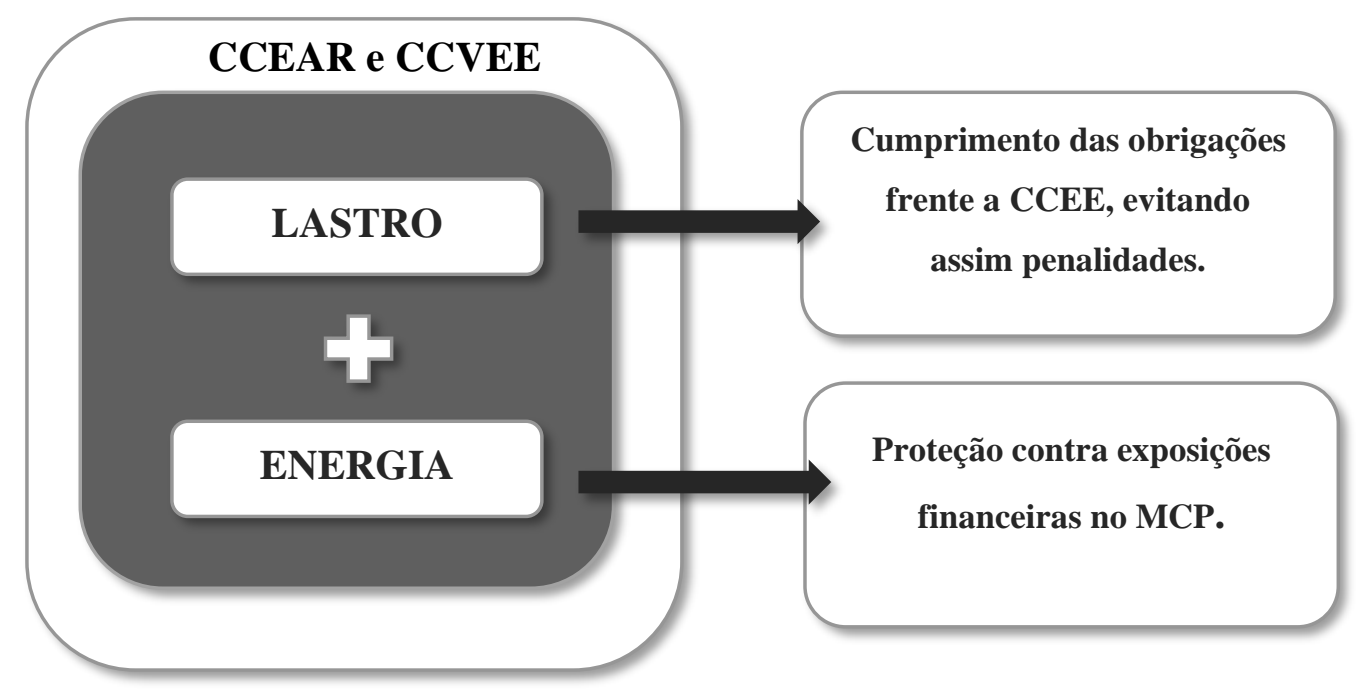

Figura 8: Estrutura e Funcionalidades dos CCEARs e CCVEEs Conforme Modelo Vigente Fonte:Autora

\footnotetext{
${ }^{5}$ Centro de Gravidade: Ponto virtual, de um determinado Submercado, onde as perdas rateadas entre os agentes produtores e consumidores, se igualam, garantindo assim que os volumes de geração e consumo contabilizados pela CCEE também se igualem.
} 
Vale ressaltar que a necessidade de comprovação de Lastro, perante a CCEE, limita a liquidez e o crescimento do mercado de energia, impedindo inclusive a criação de instrumentos financeiros mais elaborados, que possibilitariam um maior amadurecimento do mercado.

A venda conjunta do que seriam os produtos em separado Lastro e Energia acaba por misturar o que é a gestão comercial e proteção de exposições financeiras, daquilo que é a segurança de suprimento.

\subsection{Garantia Física: $O$ mecanismo de confiabilidade vigente}

Conforme discutido na seção anterior, todo o contrato comercializado no Brasil está respaldado em um Lastro, proveniente de um empreendimento de geração, sendo o Lastro respaldado por um certificado de garantia física emitido pelo MME. Ou seja, a garantia física é o mecanismo de confiabilidade presente no SEB, responsável por garantir a segurança do suprimento, na atualidade e no atendimento futuro da demanda. Concluise, então, que é ponto fulcral do sistema elétrico nacional, o cálculo adequado da garantia física, de forma que esta represente a real capacidade de geração de um empreendimento, mesmo em condições extremas.

O conceito de garantia física surgiu à época da implementação do modelo setorial vigente. O termo garantira física foi criado e regulamentado através da Lei $n^{\circ} 10.848$ de 2004, da Portaria do MME no 303 de 2004 e do Decreto no 5.163 de 2004, sendo uma evolução do conceito de Energia Assegurada6, vigente entre os anos 2000 e 2004 e do conceito de Energia Garantida ${ }^{7}$, que vigorou até o ano 2000.

Conforme (GRUPO DE TRABALHO PARA APRIMORAMENTO DO MRE GT - MRE, 2017), a garantia física do SIN é a máxima quantidade de energia que este sistema pode suprir a um dado critério de garantia de suprimento definido pelo CNPE. Até 2008, conforme estipulado pela Portaria do MME no 303 de 2004, este critério era um risco máximo de racionamento de 5\%, para um sistema bem dimensionado. Contudo, em 28 de julho de 2008, o MME publicou a Portaria n ${ }^{\circ} 258$, a qual alterou o critério para

\footnotetext{
${ }^{6}$ Energia Assegurada: Segundo (ANEEL, 2005), “a energia assegurada do sistema elétrico brasileiro é a máxima produção de energia que pode ser mantida quase que continuamente pelas usinas hidrelétricas ao longo dos anos, simulando a ocorrência de cada uma das milhares de possibilidades de sequências de vazões criadas estatisticamente, admitindo certo risco de não atendimento à carga, ou seja, em determinado percentual dos anos simulados, permite-se que haja racionamento dentro de um limite considerado aceitável pelo sistema. Na regulamentação atual, esse risco é de 5\%."

${ }^{7}$ Energia Garantida: Benefício energético, calculado por modelo determinístico, que uma usina traz ao sistema, desconsiderando perdas e indisponibilidade.
} 
a conversão pelo "critério de expansão", ou seja, a igualdade entre os CMO e o Custo Marginal de Expansão (CME), respeitando o limite de 5\% para o risco de déficit. Sendo assim, no equilíbrio, o custo marginal de operar o sistema é igual ao custo marginal de expandi-lo, sendo esta a condição ótima para a expansão.

Dada a grande participação da fonte hídrica na matriz brasileira e a incerteza acerca das condições hidrológicas futuras, o cálculo da garantia física é baseado em conceitos da teoria de Processos Estocásticos. Portanto, a confiabilidade de sistema pode adquirir diferentes níveis de exigência, conforme diferentes critérios sejam adotados na sua definição. A partir de uma simulação estática, usando o modelo NEWAVE, é definida a oferta total do sistema em MWmédios, conhecida também como carga crítica, seguindo o critério de convergência $C M O=C M E$ e respeitando o limite de déficit. Os critérios vigentes para o cálculo das garantias físicas estão descritos na Portaria MME $\mathrm{n}^{\circ} 101 \mathrm{de}$ 2016.

Com os resultados da simulação, realizada com o suporte do modelo NEWAVE, a oferta total será rateada entre dois grandes blocos, o bloco hidráulico $(\mathrm{EH})$ e o bloco térmico (ET), através da multiplicação da carga crítica pelos fatores hídrico (FH) e térmico (FT), obtidos pela ponderação das gerações hidráulica e térmica pelos CMOs. Observa-se que o EH é dado para todo o conjunto de usinas enquanto o ET pode ser calculado por usina. Isso ocorre porque o modelo NEWAVE trabalha com subsistemas equivalentes, onde as usinas hidrelétricas são representadas de forma agregada, já as usinas térmicas são representadas de forma individualizada. Portanto, no que se refere ao cálculo da garantia física para as usinas termelétricas, estas já podem ser obtidas nesta etapa da simulação, devendo apenas o valor encontrado para ET ser limitado pela disponibilidade máxima da usina.

$$
\begin{gathered}
F T(t, s)=\frac{\sum_{i=1}^{12} \sum_{j=11}^{15} \sum_{k=1}^{2000} g t(i, j, k, t, s) * c m o(i, j, k, s)}{\sum_{s=1}^{n s s} \sum_{i=1}^{12} \sum_{j=11}^{15} \sum_{k=1}^{2000}\left[g h(i, j, k, s)+\sum_{t=1}^{n t s} \operatorname{Gt}(i, j, k, s, t)\right] * \operatorname{cmo}(i, j, k, s)} \\
E T(t, s)=F T(t, s) * \sum_{s=1}^{n s s} \text { Carga Crítica }_{s}-\text { PeqUsi }
\end{gathered}
$$

\footnotetext{
${ }^{8}$ Resolução CNPE no 9 de 28 de julho de 2008.
} 
$F H=\frac{\sum_{i=1}^{12} \sum_{j=11}^{15} \sum_{k=1}^{2000} g h(i, j, k, s) * c m o(i, j, k, s)}{\sum_{s=1}^{n s s} \sum_{i=1}^{12} \sum_{j=11}^{15} \sum_{k=1}^{2000}\left[g h(i, j, k, s)+\sum_{l=1}^{n t s} G t(i, j, k, s, l)\right] * c m o(i, j, k, s)}$

$$
E H=F H * \sum_{s=1}^{n s s} \text { Carga Crítica }{ }_{s}-P e q U s i
$$

Sendo:

s: Subsistema

$t$ : Indexador da usina térmica

nss: Número de subsistemas

$i$ : Mês

$j:$ Ano

$k$ : Série

$g t$ : Geração térmica da usina

cmo: Custo marginal da operação

$l$ : Indexador da classe térmica

nts: Número de usinas termelétrica por sistema

nth: Número de usinas hidrelétricas por sistema

$g h$ : Geração hidráulica por submercado

Gt: Geração térmica total (inflexibilidade + geração flexível) da classe térmica $l$

PeqUsi: Pequenas Usinas não despachadas centralizadamente, em MW médios

Vale ressaltar que a ponderação pelo CMO segue a seguinte lógica: usinas que contribuem mais para o sistema em períodos de escassez hídrica, ou seja, períodos em que o CMO é mais alto, são mais valorizadas que as usinas que geram apenas em situações de normalidade, quando o CMO está mais baixo.

Após a obtenção do EH, utiliza-se o modelo SUISHI, desenvolvido pelo CEPEL para a simulação de Usinas Individualizadas, para o rateio desta energia entre todas as usinas, sendo este rateio proporcional à Energia Firme de cada uma delas. A Energia Firme é dada pela geração hidráulica média de cada usina no período crítico, considerando a série de vazões históricas, contabilizando não só a garantia física total da usina, mas também o benefício indireto da cascata, decorrente da entrada em operação da nova usina.

$$
\begin{gathered}
G F_{\text {Local }}=E H * \frac{E F_{h}}{\sum_{h=1}^{n h} E F_{h}} \\
G F_{h}=\operatorname{Máximo}\left(G F_{\text {Local }}+B I_{\text {Cascata }}, P o t_{\text {Ins }} *(1-T E I F) *(1-I P)\right)
\end{gathered}
$$


Sendo:

$G F_{\text {Local }}$ : Garantia Física em MW médios de energia local

$E F_{h}$ : Energia Firme da usina $h$ em MW médios

$G F_{h}$ : Garantia Física Total da usina $h$

$B I_{\text {Cascata }}$ : Benefício indireto obtido nas usinas resultante da entrada em operação do reservatório da usina hidrelétrica $h$, em MW médios

Pot $_{\text {Ins }}$ : Potência instalada da usina em MW

TEIF: Taxa equivalente de indisponibilidade forçada por unidade

$I P$ : Taxa de indisponibilidade programada por unidade

Para as usinas não despacháveis centralizadamente e outros casos específicos, utilizam-se outras metodologias de cálculo de garantia física, também definidas na Portaria MME no 101 de 2016. Para as termelétricas e as usinas solares heliotérmicas, inflexíveis e com CVU nulo, a garantia física será calculada conforme a disponibilidade mensal da usina declarada pelo gerador, discretizada mensalmente e em MWh. Com esses dados, a garantia física é calculada conforme a Equação (7) abaixo:

$$
G F=\sum_{m=1}^{12} \frac{D_{i s p_{m}}}{8760}
$$

Para as usinas eólicas, o cálculo da garantia física é baseado na produção anual de energia certificada, constante da Certificação de Medições Anemométricas e da Produção Anual de Energia, com probabilidade de ocorrência maior ou igual à noventa porcento $\left(P_{90}\right)$, conforme ilustra a Equação (8). Deste valor serão descontadas as taxas de indisponibilidade forçada, indisponibilidade programada e a estimativa anual de perdas elétrica e consumo interno $(\Delta P)$.

$$
G F=\frac{\left[P_{90} *(1-T E I F) *(1-I P)-\Delta P\right]}{8760}
$$

Para as usinas solares fotovoltaicas, o cálculo da garantia física é praticamente igual ao cálculo para as usinas eólicas, sendo a única diferença a consideração de probabilidade anual de geração igual ou inferior à cinquenta porcento. Além disso, a certificação é feita com base na Certificação de Dados Solarimétricos. 


\subsection{Proposta do Governo para Separação dos Produtos Lastro e Energia}

O conceito de Lastro está ligado à capacidade que um gerador, ou eventualmente algum outro tipo de instalação, tem de atender à demanda em determinado momento e com um padrão de qualidade pré-estabelecido.

Nesse sentido, o Lastro de um parque gerador caracteriza a máxima demanda que pode ser atendida com segurança por este parque gerador, dado um critério de segurança de suprimento (PSR, 2019).

A Consulta Pública MME nº 83 de 2019 discutiu a separação dos produtos Lastro e Energia, onde o governo apresentou ainda de forma conceitual, como pretende realizar a segregação dos produtos. Destaca-se que o produto Lastro, dentro do conceito apresentado acima, pode assumir diferentes caracterizações a depender do atributo que se esteja buscando (e.g. potência, confiabilidade, flexibilidade etc.).

A proposta do governo para separar Lastro e energia criou três produtos:

- Produção de eletricidade;

- Lastro de produção;

- Lastro de capacidade.

A produção de eletricidade seria obrigatória apenas em um período de transição, de maneira a garantir a financiabilidade dos projetos de geração, sendo posteriormente não obrigatória. Já o Lastro de produção, caracteriza um produto similar ao que hoje é a garantia física, sendo comercializado através de contratos de longo prazo e em MW médios, estando vinculado à quanto uma usina consegue contribuir à demanda de energia por um determinado intervalo de tempo. Por fim, o Lastro de capacidade seria comercializado também em contratos de longo prazo e em MW por ano, estando vinculado à capacidade da usina em atender picos de carga.

\subsection{Considerações Finais do Capítulo}

No Brasil, a adequação da oferta vem sendo garantida através do mecanismo que obriga os consumidores a contratarem energia elétrica com Lastro garantido em montantes de garantia física, conforme definido no Decreto $n^{\circ} 5.163$ de 2004, com redação alterada pelo Decreto $n^{\circ} 8.828$ de 2016 :

“Art. 2o Na comercialização de energia elétrica de que trata este Decreto deverão ser obedecidas, dentre outras, as seguintes condições: 
I - os agentes vendedores deverão apresentar Lastro para a venda de energia para garantir cem por cento de seus contratos;

$[\ldots]$

$\S 1^{\circ} \mathrm{O}$ Lastro para a venda de que trata o inciso I do caput será constituído pela garantia física proporcionada por empreendimento de geração própria ou de terceiros, neste caso, mediante contratos de compra de energia."

Neste contexto, o Brasil realiza leilões para contratação de energia no ambiente de contratação regulado com antecedência de quatro a seis anos, como forma de garantir o tempo ótimo de construção da expansão da oferta, evitando assim a ocorrência de ciclos de sobre ou sub oferta. Estes leilões, são segregados por tipos de fontes, de acordo com o planejamento do MME, garantindo assim que a expansão contratada ocorra de forma coerente com o planejamento da expansão apresentado pela EPE. Em complemento aos LEN, o governo brasileiro realizou também os LER, como ferramenta com propósito final para a adequação da expansão da oferta.

Na concepção original do SEB, a adequação do suprimento seria garantida pela obrigação de contratação de energia e potência, convivendo nos contratos negociados em âmbito nacional essencialmente três tipos de produtos: Lastro de energia, Lastro de potência e energia. O Lastro de energia iria garantir que o sistema atendesse sua demanda por energia, considerando o critério de suprimento estabelecido, enquanto o Lastro de potência garantiria o atendimento à demanda de ponta, tendo o produto energia a função de proteger o agente contra a flutuação de preços do mercado. Já os serviços ancilares, que idealmente seriam prestados pelas usinas hidrelétricas, seriam responsáveis por manter a confiabilidade do suprimento, sendo pagos por uma tarifa regulada.

Apesar das distribuidoras precisarem declarar nos leilões suas necessidades de contratação de energia e potência, conforme estipulado pela redação inicial do decreto $\mathrm{n}^{\circ}$ 5.163, de 30 de julho de 2004, os leilões não possuíam uma sistemática que conseguisse computar esta separação de produtos. Inclusive, em 2016, o decreto $\mathrm{n}^{\circ} 8.828$ alterou o decreto supracitado, retirando a obrigação de que todos os contratos estarem respaldados por Lastro de potência e que os consumidores deveriam estar contratados, em sua totalidade, em potência. Como consequência, percebe-se que os mecanismos regulatórios existentes no SEB se preocupam exclusivamente com a contratação de um montante de energia (em MWh) sem se preocupar com a o atendimento à demanda de ponta em um determinado instante de tempo. Pode-se, inclusive, citar como exemplo de mecanismos regulatórios e dispositivos de contratação, os seguintes: 
- Contratos por disponibilidade para fonte eólica e solar;

- Contratação de termelétricas movidas a gás natural importado, com despacho antecipado;

- Armazenamento virtual de energia termelétrica em reservatórios de hidrelétricas;

- Compromisso de entrega de energia com base na taxa de disponibilidade estimada dos geradores termelétricos.

Este critério mais "frouxo" de contratação da expansão, baseado exclusivamente na necessidade por energia, era suportado pela crença de que os grandes reservatórios de energia seriam grandes o suficiente para lidar com necessidades de atendimento à ponta, através de um maior turbinamento de água (e.g. reserva girante), quando necessário, e que isso teria um custo extremamente baixo, ou mesmo nulo, para o sistema.

Contudo, restrições socioambientais reduziram drasticamente a construção de novas hidrelétricas com grandes reservatórios, o que diminui a capacidade de regularização do sistema com relação à carga. Além disso, restrições hidráulicas para operação de algumas bacias, em razão de condições hidrológicas desfavoráveis, reduzem a capacidade de acompanhamento da carga pelas hidrelétricas existentes.

Deve-se somar a isso também, a forte penetração das eólicas que elevou a intermitência de geração na rede nacional, aumentando a necessidade por serviços ancilares. Tal situação, alterou substancialmente a dinâmica de despacho de termelétrica em algumas regiões do país, de forma que que estas passassem a fornecer serviços ancilares e segurança energética para o sistema elétrico nacional. Portanto, a prestação de serviços para manutenção de reserva de potência no sistema elétrico nacional deixou de funcionar conforme inicialmente planejado, assumindo um perfil mais custoso para os consumidores.

Atualmente, o ACL representa cerca de $30 \%$ do consumo de energia nacional. Todavia, sua expansão demonstrou que a simples necessidade do parque gerador por mais energia, associada aos preços praticados no mercado de curto prazo, não são sinalização suficiente para estimular uma expansão da geração de forma voluntária neste ambiente. 
Pelo contrário, a expansão do parque gerador continuou a ser sustentada majoritariamente pelo ACR, como no caso de plantas que contratam apenas um percentual de sua energia em leilões do ACR, deixando o restante para comercializar no ACL, ou através de subsídios, como é o caso da autoprodução, que possui como benefícios a redução de encargos, ou a comercialização de energia incentivada, que possui como benefício o desconto de TUST e TUSD na tarifa fio.

A principal razão para isto está na falta de celebração de contratos de longo prazo no ambiente livre, o que dificulta o Project Finance de novos projetos. Por conta da incerteza com relação aos preços futuros de energia elétrica, o financiamento destes projetos no Brasil acaba se baseando nos contratos já firmados, atribuindo o PLD mínimo como receita nos momentos em que os projetos estejam descontratados (o BNDES fornece um alívio nesse sentido, definindo um parâmetro chamado de "PLD de Referência").

Como resultado da situação descrita, observa-se atualmente uma inadequação do suprimento, que pode ser verificada pelo descompasso entre a oferta estrutural do sistema e a garantia física total. Conforme discutido no âmbito da seção 2.2, existem duas formas de se lidar com a problemática da expansão da oferta, centralizada ou via mercado, sendo que a solução centralizada envolveria a consideração dos diferentes atributos das diferentes fontes energéticas nos leilões para expansão do parque gerador, a realização de leilões para contratação de potência e, também, a revisão de garantia física com maior frequência e de maneira mais célere.

Destaca-se aqui que a separação dos produtos Lastro e Energia, dentro de um contexto mais centralizado, viabiliza o tratamento do produto Lastro conforme sua característica de bem público, ou seja provedor de segurança para o sistema, devendo de alguma forma ser pago por todos os consumidores.

A solução via mercado, por outro lado, poderia ocorrer através da criação de um mercado para a comercialização de diferentes tipos de serviços, incluindo serviços ancilares, mercado para comercialização de potência e a expansão da oferta de energia através, exclusivamente, da sinalização dos preços do mercado de curto prazo. 


\section{VALUATION}

\subsection{Modelo do Fluxo de Caixa Descontado}

Segundo (NETO, 2014), uma empresa agrega valor quando produz um resultado que supera o seu custo de capital. Em outras palavras, o valor é criado quando o retorno dos investimentos é maior que a remuneração exigida pelos fornecedores de capital. $\mathrm{O}$ excesso de lucro em relação ao custo de oportunidade é o que se denomina de valor econômico agregado.

Apesar de não ser a única metodologia para avaliação de valor de uma empresa ou projeto, a metodologia do FCD é uma das mais sofisticadas para avaliação de geração de valor no longo prazo pois consegue capturar elementos intrínsecos do negócio avaliado para a avaliação de expectativa de geração de receita futura. Quando se analisa um projeto com o FCD, a expectativa é que a soma dos valores presentes das parcelas do fluxo de caixa esperado, conforme a Fórmula (9), seja superior ao capital investido.

$$
V P L=\frac{F C_{\prime}}{(1+r)}+\frac{F C_{2}}{(1+r)^{2}}+\cdots+\frac{F C_{n}}{(1+r)^{n}}
$$

Sendo:

VPL: Valor Presente Líquido

$r$ : Taxa de Retorno

$n$ : Período da Análise

A soma dos ativos de uma empresa, sendo estes ativos operacionais e/ou fixos, deve ser igual à soma do passivo, composto pelo dinheiro dos credores, ao patrimônio líquido, que tem a finalidade de remunerar acionistas ou cotistas. A Figura 9 abaixo ilustra a estrutura dos resultados de uma empresa, na forma de um balanço patrimonial:

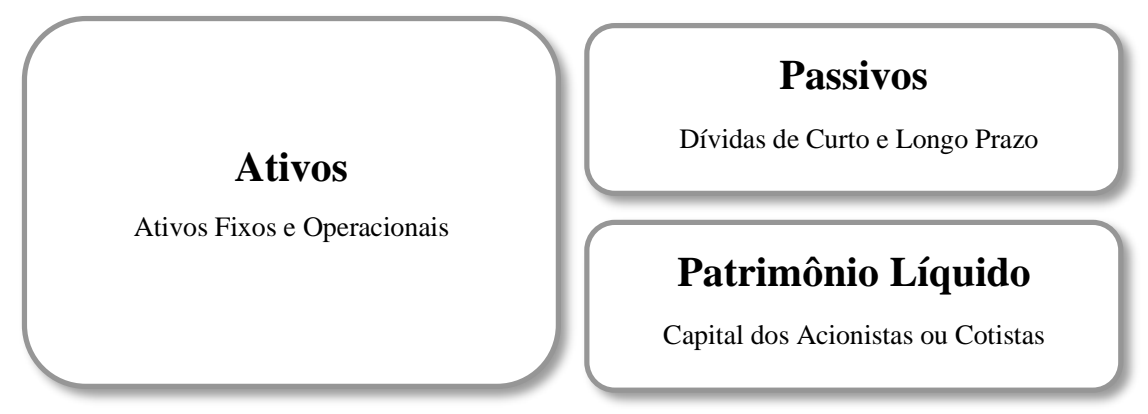

Figura 9: Estrutura do balanço patrimonial

Fonte: Autora 
Conforme antes pontuado, são os resultados operacionais de uma empresa que medem sua capacidade de produzir retornos através de seus ativos, ou seja, através de sua atividade principal. Sendo assim, toda vez que o resultado operacional de uma empresa for superior ao custo de oportunidade do dinheiro investido, a empresa agregará valor a seu investidor. O fluxo de caixa de uma empresa, é componente fundamental do valuation e pode ser determinado a partir da Receita Bruta Operacional, conforme ilustra a Figura 10 a seguir:

Receita Bruta Operacional

(-) Deduções (Ex: PIS, Confins, ICMS, IPI,...)

Receita Líquida Operacional

(-) Custos e Despesas Operacionais (antes da amortização)

EBITDA (Earnings Before Interest, Taxes, Depreciation and Amortization)

(-) Depreciação

EBIT (Earnings Before Interest and Taxes)

(-) Imposto sobre o Lucro

NOPAT (Net Operational Profit After Taxes)

(+) Depreciação

(-) Investimento Bruto (CAPEX)

(-) Variações na Necessidade de Capital de Giro

(+) Valor Residual

\section{Fluxo de Caixa do Projeto}

Figura 10: Como Chegar no Fluxo de Caixa de Um Projeto

Fonte: Autora

A Receita Bruta Operacional é a receita de venda que a empresa observa ao final de um período. Para que esta represente apenas a atividade final do negócio, deverão ser desconsideradas desta linha qualquer outro tipo de receita observada pela empresa, naquele período, que não estejam vinculadas à atividade principal da empresa.

Os Custos e Despesas Operacionais expostos na Figura 10, que são descontados da Receita Líquida Operacional para obtenção do EBITDA (Earnings Before Interest, Taxes, Depreciation and Amortization), representam todo gasto operacional necessário para a continuidade do projeto. Além disso, estes custos podem ser divididos em custos fixos e custos variáveis, sendo os fixos independentes do volume de produção, enquanto as variáveis são dependentes. 
O EBITDA, em português LAJIDA (Lucro Antes de Juros, Impostos, Depreciação e Amortização), é utilizado para medir o potencial de geração de fluxo de caixa de uma empresa. A avaliação da evolução deste indicador um bom guia para avaliação da gestão da companhia, em escala global, dado que diferentes países possuem diferentes políticas contábeis quanto à depreciação e diferentes políticas de impostos. Contudo, deve-se atentar que a avaliação do valor de uma empresa através apenas do EBTIDA pode mascarar níveis de alavancagem e reinvestimentos inadequados, uma vez que, não leva em conta despesas financeiras. Portanto, ao observar apenas o EBITDA estamos desconsiderando o impacto da estrutura de capital da empresa em sua avaliação. Esta análise pode mascarar informações importantes sobre a qualidade de gestão de capital da empresa, o que é muito importante no setor elétrico, por ser este um setor de capital intensivo. Uma boa gestão da estrutura de capital pode trazer grandes vantagens para uma companhia, portanto sua avaliação não pode ser negligenciada quando tratamos de avaliar o valor gerado pela entidade em questão.

Para o cálculo do EBIT (Earnings Before Interest and Taxes), também conhecido com LBO (Lucro Bruto Operacional), desconta-se do EBITDA a Depreciação. Esta não é um desembolso efetivo, porém, é descontada do fluxo de caixa, trazendo benefício fiscal ao mesmo. Por conta disso, após a apuração do imposto, a Depreciação é novamente somada ao valor do projeto para composição do fluxo de caixa final.

Para a depreciação foi utilizado o método linear com base no valor do investimento realizado e na vida útil do projeto, que está relacionado com o período de concessão. No caso do valor do investimento, foi considerado como base o valor histórico de investimento considerado pela ANEEL para os Leilões do SEB, pois são mais aderentes à realidade nacional.

Para se chegar ao fluxo de caixa a partir do NOPAT (Net Operation Profit After Taxes), ainda é necessário, além de somar a Depreciação, subtrair o CAPEX (Capital Expenditure) e as variações da Necessidade de Capital de Giro (NCG), somando por fim o Valor Residual. O CAPEX representa o investimento realizado na aquisição dos ativos fixos para a realização do projeto. Já a NCG representa a diferença entre as contas operacionais do ativo e as contas do passivo. Por fim, o Valor Residual representa a diferença entre o valor contábil do projeto em seu último ano e o valor de mercado do empreendimento. 
Destaca-se aqui que o Fluxo de Caixa do Projeto ou da Empresa, que é o fluxo de caixa desalavancado, conhecido em inglês como Free Cash Flow to the Firm (FCFF), irá remunerar a todos os envolvidos no financiamento do projeto, sejam estes acionistas ou credores, contudo, já sendo livre de impostos.

Para saber, por fim, qual é a remuneração do acionista do projeto, calcula-se o Fluxo de Caixa Livre do Acionista, também conhecido em inglês como Free Cash Flow to Equity (FCFE), que é o fluxo de caixa alavancado. Ilustra-se a seguir, duas formas de calcular o Fluxo de Caixa do Acionista, uma a partir do NOPAT:

\begin{tabular}{l}
\hline Lucro Operacional Líquido de IR (NOPAT) \\
\hline (+) Depreciação e Amortização \\
(-) Variação do Capital de Giro \\
(-) CAPEX \\
\hline Fluxo de Caixa da Empresa ou do Projeto (FCFF) \\
\hline (-) Despesas Financeiras \\
(+) Benefício Fiscal \\
(+) Entrada de Novas Dívidas \\
(-) Pagamento de Principais de Dívidas \\
\hline Fluxo de Caixa do Acionista (FCFE)
\end{tabular}

Figura 11: Cálculo do Fluxo de Caixa do Acionista através do NOPAT Fonte: Autora

E outra através do Lucro Líquido:

\begin{tabular}{l}
\hline Lucro Líquido \\
\hline (+) Depreciação e Amortização \\
\hline Fluxo de Caixa das Operações \\
\hline (-) CAPEX \\
(-) Variação do Capital de Giro \\
(+) Entrada de Novas Dívidas \\
(-) Pagamento de Principais de Dívidas \\
\hline Fluxo de Caixa do Acionista (FCFE) \\
\hline
\end{tabular}

Figura 12: Cálculo do Fluxo de Caixa do Acionista através do Lucro Líquido Fonte: Autora

O FCFF também é conhecido como Fluxo de Caixa Livre Desalavancado, ou em inglês como Unlevered Free Cash Flow, enquanto o FCFE é conhecido também como Fluxo de Caixa Livre Alavancado, ou em inglês como Levered Free Cash Flow.

A principal diferença entre o FCFF e o FCFE é que o FCFF exclui o impacto dos custos de juros da dívida, assim como a emissão ou a amortização da dívida, enquanto o 
FCFE os considera. A Figura 13 a seguir ilustra um exemplo numérico do cálculo de ambas as métricas.

\begin{tabular}{|c|c|c|c|c|c|}
\hline \multirow[b]{2}{*}{ (in millions) } & \multicolumn{5}{|c|}{ Year ended December 31, } \\
\hline & 2017 & 2016 & 2015 & 2014 & 2013 \\
\hline \multicolumn{6}{|l|}{ Cash from Operations } \\
\hline Net Income & $\$ 14,360$ & $\$ 12,760$ & $\$ 11,320$ & $\$ 8,960$ & $\$ 5,400$ \\
\hline \multicolumn{6}{|l|}{ Adjusted for: } \\
\hline Depreciation & 500 & 500 & 500 & 450 & 400 \\
\hline Stock based compensation & 0 & 0 & 0 & 0 & 0 \\
\hline Change in accounts receivable & (200) & 500 & 900 & $(1,500)$ & $(1,000)$ \\
\hline Change in inventory & 1,000 & $(3,000)$ & 1,300 & 2,000 & $(14,000)$ \\
\hline Change in accounts payable & 500 & $(500)$ & $(500)$ & 500 & 1,000 \\
\hline Cash from Operations & $\$ 16,160$ & $\$ 10,260$ & $\$ 13,520$ & $\$ 10,410$ & $(\$ 8,200)$ \\
\hline \multicolumn{6}{|l|}{ Cash from Investing } \\
\hline Purchase of PP\&E & $(\$ 500)$ & $(\$ 5,500)$ & $(\$ 1,200)$ & $(\$ 5,450)$ & $(\$ 40,400)$ \\
\hline Acquisition of businesses & 0 & 0 & 0 & 0 & 0 \\
\hline Cash from Investing & $(\$ 500)$ & $(\$ 5,500)$ & $(\$ 1,200)$ & $(\$ 5,450)$ & $(\$ 40,400)$ \\
\hline \multicolumn{6}{|l|}{ Cash from Financing } \\
\hline Issuance (repayment) of debt & 0 & 6,000 & 5,000 & 3,500 & 18,500 \\
\hline Issuance (repayment) of equity & 0 & 0 & 0 & 0 & 30,000 \\
\hline Dividends & 0 & 0 & 0 & 0 & 0 \\
\hline Cash from Financing & 0 & 6,000 & 5,000 & 3,500 & 48,500 \\
\hline Net Change in Cash & $\$ 15,660$ & $\$ 10,760$ & $\$ 17,320$ & $\$ 8,460$ & $(\$ 100)$ \\
\hline Cash at beginning of period & 49,190 & 38,430 & 21,110 & 12,650 & 12,750 \\
\hline Cash at end of period & $\$ 64,850$ & $\$ 49,190$ & $\$ 38,430$ & $\$ 21,110$ & $\$ 12,650$ \\
\hline EBITDA & $\$ 18,500$ & $\$ 16,500$ & $\$ 14,700$ & $\$ 11,700$ & $\$ 7,200$ \\
\hline Cash Flow (CF) & $\$ 16,160$ & $\$ 10,260$ & $\$ 13,520$ & $\$ 10,410$ & $(\$ 8,200)$ \\
\hline Free Cash Flow (FCF) & $\$ 15,660$ & $\$ 4,760$ & $\$ 12,320$ & $\$ 4,960$ & $(\$ 48,600)$ \\
\hline Free Cash Flow to Equity (FCFE) & $\$ 15,660$ & $\$ 10,760$ & $\$ 17,320$ & $\$ 8,460$ & $(\$ 30,100)$ \\
\hline Unlevered Free Cash Flow (FCFF) & $\$ 15,700$ & $\$ 4,800$ & $\$ 12,360$ & $\$ 5,000$ & $(\$ 48,560)$ \\
\hline \multicolumn{6}{|l|}{ Unlevered Free Cash Flow (FCFF) } \\
\hline EBIT & $\$ 18,000$ & $\$ 16,000$ & $\$ 14,200$ & $\$ 11,250$ & $\$ 6,800$ \\
\hline Tax & $(3,600)$ & $(3,200)$ & $(2,840)$ & $(2,250)$ & $(1,360)$ \\
\hline D\&A and Other Non-Cash & 500 & 500 & 500 & 450 & 400 \\
\hline Chang in NWC & 1,300 & $(3,000)$ & 1,700 & 1,000 & $(14,000)$ \\
\hline Capex & $(500)$ & $(5,500)$ & $(1,200)$ & $(5,450)$ & $(40,400)$ \\
\hline Free Cash Flow to the Firm & $\$ 15,700$ & $\$ 4,800$ & $\$ 12,360$ & $\$ 5,000$ & $(\$ 48,560)$ \\
\hline
\end{tabular}

Figura 13: Exemplo numérico de cálculo do Fluxo de Caixa Livre da Firma e do Acionista. Fonte: Corporate Finance Institute ${ }^{9}$

\footnotetext{
${ }^{9}$ Fonte: https://corporatefinanceinstitute.com/resources/knowledge/valuation/fcff-vs-fcfe/
} 


\subsection{A Taxa de Desconto}

A definição da taxa de desconto dos fluxos de caixa de um projeto é parte fundamental do valuation, pois nela estará refletida a percepção de risco do investidor.

Uma das formas mais comuns de medir a taxa de retorno do investimento é através da metodologia do Custo Médio Ponderado de Capital (conhecido em inglês como Weighted Average Cost of Capital - WACC), estando representada nela tanto a parcela da remuneração de capital recebida pelos investidores, quanto pelos credores, ou seja, sobre todo o capital investido. O WACC reflete a estrutura de capital da empresa e possui de forma simplificada a seguinte formulação:

$$
W A C C=k_{d}(1-t) \frac{D}{V}+k_{e} \frac{E}{V}
$$

Onde:

$K_{d}$ : Custo explícito do capital de terceiros

$K_{e}$ : Custo de oportunidade do capital próprio

$t$ : Alíquota de imposto

$D$ : Capital de terceiros a valor de mercado (com juros)

$E$ : Capital próprio a valor de mercado

$V$ : Capital total investido na empresa a valor de mercado

No setor elétrico brasileiro, a metodologia do WACC é utilizada pela ANEEL para o cálculo da taxa de retorno de serviços regulados de distribuição, transmissão e geradores cotistas. Outros serviços regulados no Brasil que utilizam esta metodologia são: água, gás, telecomunicações, ferrovias e rodovias. Uma exceção nacional à utilização desta metodologia é Agência Nacional de Aviação Civil (ANAC), que a substituiu recentemente.

Algumas metodologias regulatórias alternativas ao WACC, optam por observar apenas o capital próprio, sendo o capital de terceiros pago integralmente ou considerado dentro dos custos operacionais. Conforme (ANEEL, 2019), em outros casos, a remuneração é paga como uma anuidade, como rentabilidade sobre os ativos a ser admitida dentro de um intervalo mínimo e máximo, dentro do qual se estabelece uma taxa central. No cenário internacional, observa-se a seguinte divisão entre os reguladores de setores elétricos que optam ou não pela utilização do WACC: 


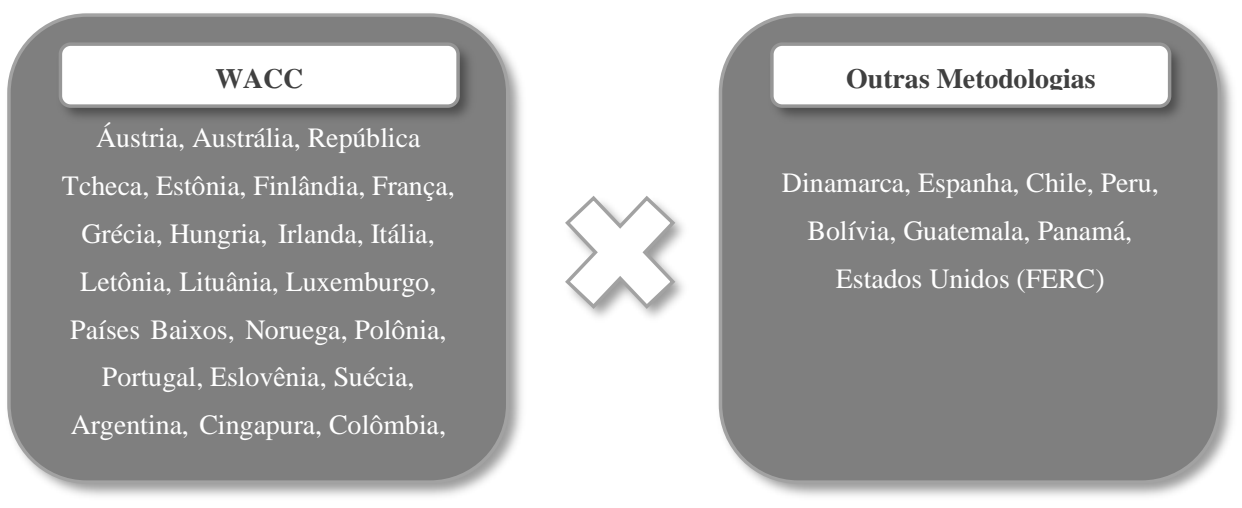

Figura 14: Países que utilizam o WACC ou outra metodologia para a Taxa De Retorno Regulatória.

Fonte: Autora

Conforme se pode observar em sua formulação, o WACC não é um parâmetro que pode simplesmente ser observado, posto que depende de diferentes inputs e deve ser estimado com base em diversas premissas. Nas próximas seções, cada uma destas premissas será observada com mais atenção. Outra observação que deve ser feita aqui é que a taxa de desconto de um projeto deve refletir os riscos envolvidos no projeto em si, e não a taxa de remuneração do capital que é comumente utilizada por quem está analisando o projeto. Em (BRAGANÇA, 2017), um estudo realizado pela FGV Energia, mostra valores aproximados do custo de capital de projetos em novas fontes renováveis, divido por parâmetros componente do WACC, conforme ilustra a figura abaixo:

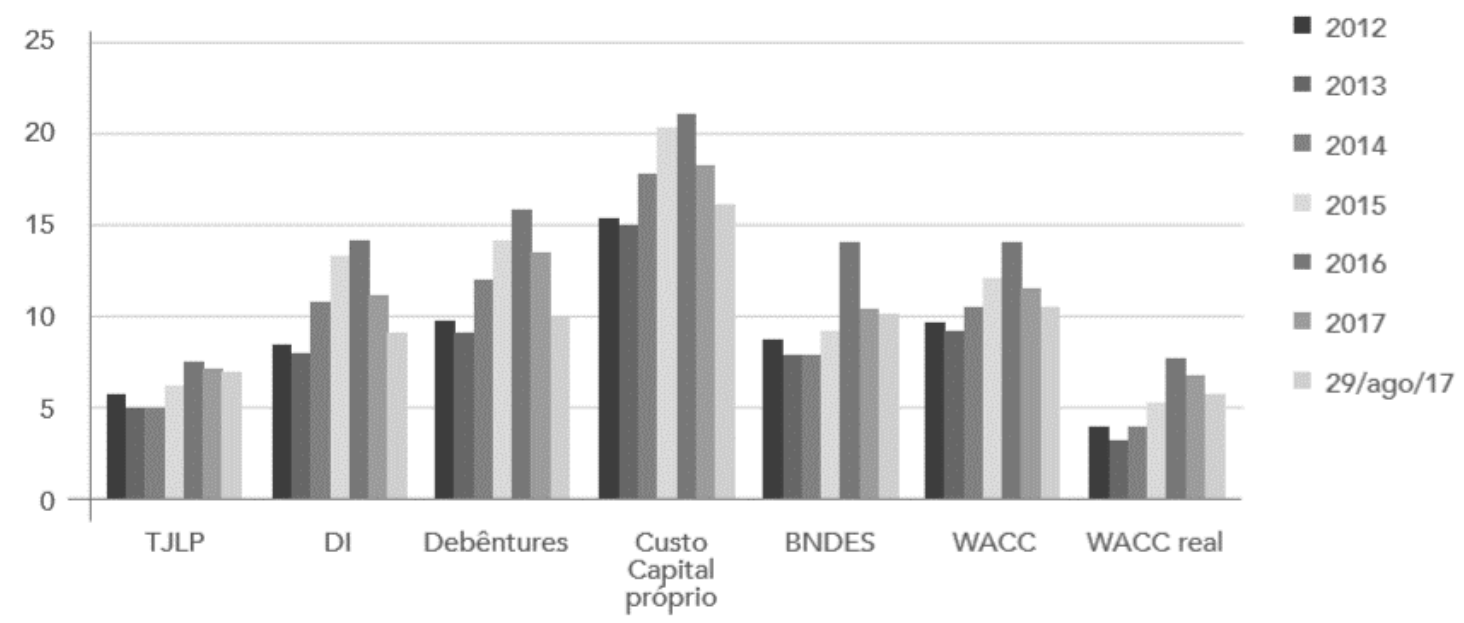

Figura 15: Evolução do custo de capital aproximado de projetos em novas fontes renováveis. Fonte: FGV Energia, Anbima, Banco Central do Brasil e BNDES

Nas próximas seções serão discutidas as formas de estimar as diferentes componentes do WACC. 


\subsubsection{A Taxa Livre de Risco}

Define-se um ativo livre de risco como aquele em que o investidor sabe o retorno esperado com certeza (DAMODARAN, 2006) ${ }^{10}$. Além disso, (DAMODARAN, 2006) define duas condições básicas para a determinação da taxa livre de risco; a primeira é que não haja risco inadimplência e a segunda é que não existam incertezas com relação às taxas de retorno do título. Porém, na realidade, nenhum investimento é completamente livre de risco. Mesmo os investimentos mais seguros, como títulos de dívida do tesouro de longo prazo, possuem um risco atrelado ao risco de default dos países os quais os emitem.

Quanto maior for o risco de default de um país, maior será sua taxa livre de risco. Nos Estados Unidos da América, por exemplo, os T-Bonds (Treasury Bonds) com maturidade similar ao investimento analisado são utilizados como referência para a taxa livre de risco. Deve-se observar, contudo, que as taxas de retorno de diferentes títulos públicos variam conforme a duração dos mesmos.

Conforme Damodaran em (DAMODARAN, 2006), pode-se considerar como estratégia a compatibilidade da duração dos ativos em questão, ou seja, utilizar títulos públicos com a mesma duração que a dos fluxos de caixa dos ativos em análise. No caso de valutions que consideram a perpetuidade, deve-se considerar a utilização do título com duração mais longa possível, que pode variar entre 10 a 30 anos, dependendo do país de emissão.

É importante frisar que a taxa livre de risco utilizada no valuation deve ser referenciada no país da moeda em que a análise está sendo feita. Por exemplo, se o valuation está sendo feito para um investimento no Brasil, porém a análise está sendo realizada em dólares americanos, a taxa livre de risco utilizada deve ser a americana. Outro ponto de atenção é com relação à inflação. Quando o valuation é realizado em uma moeda de um país com inflação alta e instável, pode-se utilizar taxa livre de risco em termos reais.

Uma outra visão com relação a adequação da duração dos títulos públicos na definição da taxa livre de risco, com ênfase na fase maturidade dos mercados, é dada em (ANEEL, 2018):

\footnotetext{
${ }^{10}$ Tradução livre do texto original em inglês: "We defined a risk-free asset as one where the investor knows the expected return with certainty."
} 


\begin{abstract}
“Baseado em estudo da Standard \& Poor's, Damodaran (2008) explica que o título do tesouro americano com maturidade de 10 anos serve como ativo livre de risco para o fluxo de caixa da maioria das empresas maduras. No caso de empresas em crescimento, a maturidade mais apropriada seria de 20 a 25 anos. Assim, o autor considera que a melhor pratica é utilizar o título de 10 anos como taxa livre de risco sobre todos os fluxos de caixa de mercados maduros, mas quando se trata de fluxos específicos e que variam muito ao longo do tempo, a taxa de 30 anos seria mais adequada."
\end{abstract}

Conforme exposto em (ANEEL, 2018), a agência usualmente utiliza a média do retorno dos títulos do governo americano com maturidade de 10 anos, iniciando na maioria das vezes, o período de cálculo em 1995 e crescendo nos anos seguintes, para o cálculo da taxa de retorno regulada dos segmentos de geração (cotista), distribuição e transmissão. Ainda conforme (ANEEL, 2018), a exceção foi o processo de remuneração do segmento de distribuição, no ano de 2015, quando foi utilizada janela de 30 anos, mas manteve a maturidade de 10 anos do referencial.

Atualmente, a ANEEL discute o WACC regulatório através da Audiência Pública número 9 de 2019. Entre as propostas da agência, está a substituição da utilização dos títulos públicos americanos por títulos públicos brasileiros que pagam juros reais e são indexados à inflação (NTN-B). Conforme (ANEEL, 2019), a opção considerada mais viável foi não se limitar a uma única série de títulos, mas a uma carteira formada por papéis com vencimento superior a cinco anos, que representam um estoque de $R \$ 504$ bilhões. Para fins deste trabalho, serão utilizadas as NTN-B, excluindo assim a necessidade de estimar a taxa livre de risco com base no risco país.

Conforme (ANEEL, 2019), o fato das NTN-B possuírem maior representatividade no estoque da dívida pública, além de outros fatores também listados no documento, faz com que sejam uma melhor proxy para a taxa livre de risco no Brasil:

“A NTN-B possui maior representatividade no estoque de dívida pública federal do que os títulos brasileiros denominados em moeda estrangeira utilizados como referência para o cálculo do risco país. Dados do Tesouro Nacional14 revelam que que em maio de 2018, o estoque de NTN-B representava $26,5 \%$ da dívida pública federal (R $\$ 985$ bilhões), enquanto os títulos denominados em dólares eram 3,06\% ( $\mathrm{R} \$ 114$ bilhões). O volume financeiro médio diário negociado das NTNB no mercado secundário em maio/2018 foi de R $\$ 13$ bilhões, contra a média diária de $\mathrm{R} \$ 10$ bilhões dos últimos doze meses, ficando atrás apenas das Letras do Tesouro Nacional (LTN), com R $\$ 15$ bilhões em maio/2018 em média diária de $\mathrm{R} \$ 12$ bilhões nos últimos doze meses." 
Com relação à prática internacional, pode-se observar a seguinte divisão entre países que optam por títulos públicos domésticos ou títulos públicos estrangeiros para definição da taxa de remuneração do capital no setor elétrico:
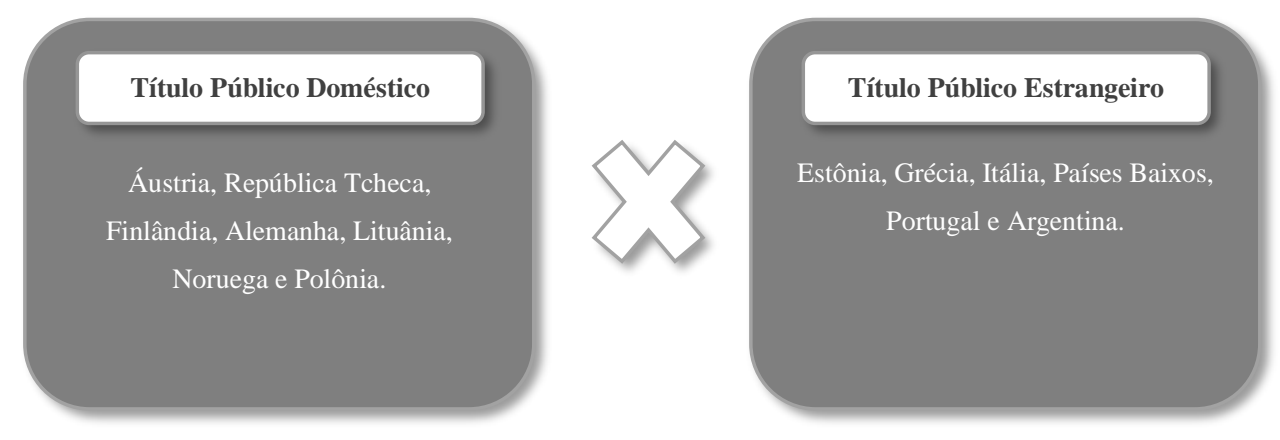

Figura 16: Opção por Títulos Públicos Domésticos ou Estrangeiros na Definição da Taxa de Remuneração do Capital do Setor Elétrico.

Fonte: Autora

\subsubsection{Custo de Capital de Terceiros}

O custo de capital de terceiros, $k_{d}$, também conhecido como custo da dívida, é um custo explícito que representa o custo para empresa ao obter empréstimos e financiamentos no mercado. Apesar de poder se financiar integralmente pelo capital próprio, empresas costumam captar capital de terceiros por este ser menos oneroso financeiramente. Como o custo do capital de terceiros tem prioridade em relação à renda dos acionistas no fluxo de caixa das empresas, este custo acaba sendo mais barato para a empresa.

O custo do capital de terceiros varia conforme o nível de risco do projeto, o prazo do financiamento ou empréstimo, o risco financeiro mantido pela empresa proprietária do projeto, entre outras variáveis. De forma simplificada, pode-se assumir que o custo do capital de terceiros é a soma da taxa livre de risco ao spread de risco de inadimplência da empresa, subtraído de um eventual benefício fiscal, conforme a fórmula abaixo:

$$
k_{d}=r_{f}+\text { SpreadEmpresa-BenefícioFiscal }
$$

Onde:

$$
\begin{aligned}
& k_{d}: \text { Custo da dívida } \\
& r_{f} \text { : Taxa livre de risco }
\end{aligned}
$$


Devido à globalização e ao crescimento considerável da participação na economia global de países emergentes, pode ser necessário representar, no custo da dívida da empresa, o risco país ao qual esta dívida está exposta. Segundo (NETO, 2014), é proposto que nenhuma empresa pode tomar recursos no exterior pagando uma taxa de juros menor que o país desembolsaria, carregando sempre o risco país em todas as suas operações realizadas no mercado financeiro internacional. Nesse contexto, para empresas localizadas em países emergentes, a fórmula para determinação do custo da dívida pode ser dada por:

$$
k_{d}=r_{f}+\text { SpreadEmpresa }- \text { BeneficioFiscal }+ \text { RiscoPaís }
$$

Diferentemente do custo de capital próprio, que não pode ser efetivamente observado, o custo de capital de terceiros pode ser estimado através de informações públicas, como demonstrações societárias de empresas de capital aberto. Sendo assim, em ambientes regulados, como para os negócios de geração cotista, distribuição e transmissão, o Regulador pode optar ou por reconhecer o custo real da dívida, ou por reconhecer um custo estimado da dívida com base em dados observáveis no mercado de capitais.

A ANEEL propôs em (ANEEL, 2019), alterar a metodologia até então utilizada para o cálculo do custo de capital de terceiros, para seus processos regulatórios de revisão tarifária, da utilização dos riscos de crédito estimados pelas agências de rating para empresas, para a utilização de dados do mercado de debêntures. Conforme (ANEEL, 2018), uma das dificuldades da metodologia vigente é replicar a série de dados de spread de risco de crédito da agência de classificação de risco Moody's, já que esses dados são privados. Nesse sentido, a proposta de utilização das debentures é interessante, uma vez que, sua precificação diária para o mercado secundário pode ser observada no website da Associação Brasileira das Entidades dos Mercados Financeiro e de Capitais (ANBIMA). Além disso, a utilização das debêntures permite a diferenciação do custo do capital de terceiros entre os segmentos regulados (geração cotista, distribuição e transmissão) e competitivos (geração não cotista). Vale ressaltar que ao custo das debentures deve-se somar o custo para a empresa de emissão daquele papel como comissões aos bancos coordenadores e demais taxas. 
Dentro das emissões de debêntures no cenário nacional, deve-se destacar o crescimento de emissões de debêntures de infraestrutura incentivadas, regulamentadas pela Lei $\mathrm{n}^{\circ} 12.431$ de 2011. Do total de papéis emitidos entre 2012 e 2018, cerca de $89 \%$ correspondiam à investimentos vinculados ao MME.

Independentemente do valor observado do capital de terceiros no ambiente regulado, para o valuation de um projeto, como no âmbito deste trabalho, é importante que o investidor use a informação mais condizente possível com o seu real custo de captação, avaliando inclusive a possibilidade de obtenção de benefícios fiscais, como, por exemplo, no Brasil através da Superintendência do Desenvolvimento da Amazônia (SUDAM) e a Superintendência do Desenvolvimento do Nordeste (SUDENE), ou a emissão de dívidas através de papéis incentivados, como as debêntures de infraestrutura subscritas pelo Banco Nacional do Desenvolvimento (BNDES).

\subsubsection{Custo do Capital Próprio}

O custo do capital próprio, $k_{e}$, é um custo implícito que representa a expectativa de retorno dos investidores sobre aquele negócio e varia de investidor para investidor, de acordo com sua percepção e aversão ao risco. Dentre os modelos existentes para mensuração do risco, o CAPM (Capital Asset Pricing Model) ainda é um dos mais utilizados, tendo como principais premissas custo nulo para as transações e a equidade de informações entre todos os investidores. O CAPM tem como base metodológica os trabalhos (SHARPE, 1964), (LINTNER, 1965) e (MOSSIN, 1966) de Sharpe, Lintner e Mossin, baseados na Teoria dos Portfólios de Markowitz (1952).

Formas alternativas ao CAPM, também comumente utilizadas, para se calcular o custo do capital próprio, além do Modelo dos Dividendos Descontados (MDD), foram propostas por Stephen A. Ross em The arbitrage theory of capital asset pricing (1976), por Eugene Fama e Kenneth French em Common riskfactors in the returns on stocks and bonds (1993), por Mark Carhart em On Persistence in Mutual Fund Performance (1997), e novamente por Eugene Fama e Kenneth French em A five-factor asset pricing model (2005).

Diversos tipos de risco irão compor o risco final percebido de um ativo, podendo estes serem divididos em dois tipos: diversificáveis e não diversificáveis. Os riscos diversificáveis são riscos inerentes àqueles ativos em específico e não tem qualquer influência sobre demais investimentos. 
Já os riscos não diversificáveis, caracterizam riscos derivados do mercado e possuem influência sobre qualquer investimento que seja realizado. A formulação básica do CAPM é:

$$
r_{e}=r_{f}+\beta\left(r_{m}-r_{f}\right)
$$

Onde:

$r_{e}$ : Taxa de retorno esperada do ativo (custo de capital próprio)

$r_{f}$ : Taxa retorno livre de risco

$\beta$ : Coeficiente que representa a relação entre o retorno do ativo em questão quando comparado com o retorno do mercado.

$r_{m}$ : Taxa de retorno esperado do mercado

O coeficiente $\beta$ representa a relação entre o retorno do ativo em questão e o retorno do mercado no qual está inserido. Tal relação pode ser calcula pela fórmula abaixo:

$$
\beta=\frac{\operatorname{cov}\left(r_{i}, r_{m}\right)}{\operatorname{var}\left(r_{m}\right)}
$$

Sendo:

$r_{i}:$ retorno do ativo em questão

Á diferença entre $r_{i}$ e $r_{m}$ se dá o nome de prêmio de risco.

Conforme (ANEEL, 2018), de acordo com a teoria do CAPM, o beta mede a sensibilidade dos retornos de um ativo aos movimentos do mercado, podendo ser calculado por meio da correlação entre os retornos das ações de um ativo e uma carteira que representa o mercado. Portanto, betas mais altos estão relacionados a ativos que flutuam mais conforme as movimentações observadas no mercado, enquanto betas menores indicam que um ativo flutua menos que as movimentações do mercado.

Quando analisando o beta, o investidor deve atentar que o resultado da Equação (14) inclui também o risco financeiro do ativo observado (estrutura de capital e benefícios fiscais). Portanto, para eliminar o risco financeiro inerente à estrutura de capital do ativo em questão, deve-se desalavancar o beta conforme a formulação a seguir:

$$
\beta_{D}=\beta_{\alpha} \frac{E}{1-D * t}
$$

Onde:

$\beta_{D}$ : Beta desalavancado 


$$
\begin{aligned}
& \beta_{\alpha} \text { : Beta alavancado } \\
& E \text { : Participação em capital próprio } \\
& D: \text { Participação em capital de terceiros } \\
& t: \text { Alíquota tributária }
\end{aligned}
$$

A abordagem utilizada pela ANEEL para o cálculo do beta regulatório é explicitada em (ANEEL, 2018), como sendo baseada no mercado americano, representado pelo Índice $S \& P$ 500, que é composto pelas 500 maiores empresas negociadas na Bolsa de Nova York. Como muitas empresas do índice performam atividades não relacionadas com o setor elétrico, optou-se nas últimas vezes pela utilização de empresas membro do índice Edison Electric Institute (EEI). Em alguns processos regulatórios, a ANEEL filtrou os membros do índice em que pelo menos $50 \%$ dos ativos fossem destinados aos negócios de transmissão e distribuição. Nessa metodologia, primeiramente calcula-se um beta setorial médio americano, sendo este parâmetro posteriormente desalavancado com base na estrutura da capital média dessas empresas nos Estados Unidos. Uma vez calculado o beta médio setorial americano desalavancado, este passa a ser alavancado pela estrutura média de capital das empresas brasileiras deste setor, que será então utilizado no cálculo do WACC. Esta metodologia é a mais utilizada em países como o Brasil, pois países emergentes não costumam possuir um índice de ações com liquidez e volume suficientes para a determinação do próprio beta setorial.

$\mathrm{Na}$ tabela abaixo tem-se os betas alavancados e desalavancados utilizados pela ANEEL nos últimos processos de revisão da taxa de retorno regulatório em diferentes segmentos:

Tabela 1: Tabela 2: Betas utilizados pela ANEEL em processos de Revisão Tarifária Periódica.

\begin{tabular}{l|cc}
\multicolumn{1}{c}{ REVISÃO - SEGMENTO - DATA } & $\begin{array}{c}\text { EUA - } \\
\text { (DESALAVANCADO) }\end{array}$ & $\begin{array}{c}\text { BRASIL - } \\
\text { (ALAVANCADO) }\end{array}$ \\
\hline 3 $^{\mathbf{a}}$ RTP - TRANSMISSÃO - MAI DE 2013 & 0,44 & 0,88 \\
$\mathbf{1}^{\mathbf{a}}$ RTP - GERAÇÃO- MAR DE 2014 & 0,44 & 0,73 \\
4 $^{\mathbf{a}}$ RTP - DISTRIBUIÇÃO - JAN DE 2015 & 0,43 & 0,70
\end{tabular}

Fonte: ANEEL

Alguns países ${ }^{11}$ adotam o cálculo de um beta global, ou seja, com referência em empresas semelhantes atuantes em diferentes países.

\footnotetext{
${ }^{11}$ Áustria, Bélgica, República Tcheca, Estônia, Finlândia, Grã-Bretanha, Grécia, Irlanda, Itália, Lituânia, Países Baixos, Noruega, Polônia, Portugal, Eslovênia e Singapura (Fonte: ANEEL)
} 
A ideia por traz de tal metodologia é buscar um beta característico do setor. A utilização de um beta com referência na bolsa de valores brasileira também não deve ser descartada, uma vez que representaria características inerentes à regulação local, concentração, volume e liquidez dos papéis. Muitas vezes esta opção é criticada devido à falta de maturidade e representatividade do mercado brasileiro, quando comparado aos mercados internacionais.

Outra componente relevante para o cálculo do CAPM é o prêmio de risco de mercado $\left(r_{m}-r_{f}\right)$, que é justamente o quanto um investidor ganha por investir no mercado de ações ao invés de investir no ativo livre de risco. Para tal, opta-se por utilizar séries longas de tempo tanto para o índice de mercado quanto para o ativo livro de risco de forma a eliminar os efeitos dos ciclos econômicos. Com relação ao prêmio de risco de mercado, ANEEL vem utilizando nos últimos para sua metodologia de cálculo dos WACC regulatórios o gap entre o retorno do mercado estadunidense, através do índice $S \& P 500$ e os títulos do Tesouro Americano com maturidade de 10 anos. Conforme (ANEEL, 2018):

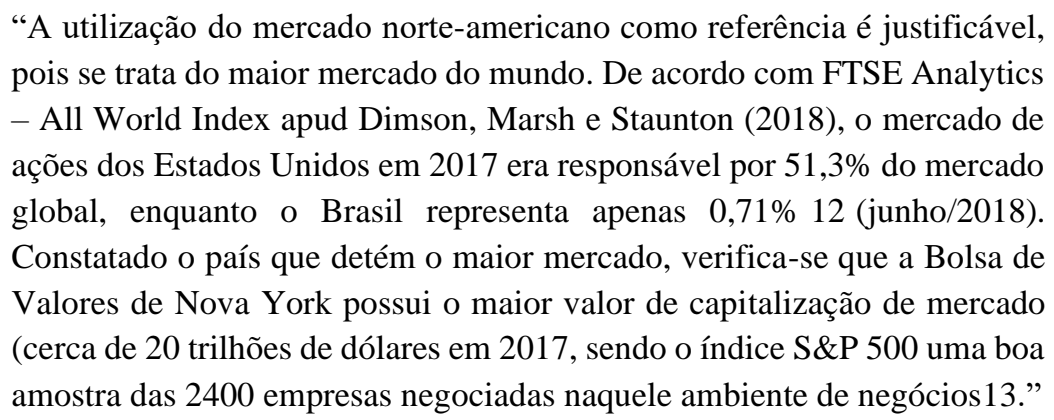

$\mathrm{Na}$ tabela a seguir tem-se os prêmios de risco de mercado utilizados pela ANEEL nos últimos processos de revisão da taxa de retorno regulatório em diferentes segmentos:

Tabela 3: Histórico do prêmio de risco de mercado utilizado pela ANEEL nos processos de revisão tarifária.

\begin{tabular}{|c|c|c|c|}
\hline REVISÃO - SEGMENTO - DATA & JANELA & $\begin{array}{l}\text { HISTÓRICO } \\
\text { (ANOS) }\end{array}$ & \% MÉDIO \\
\hline 1 $^{a}$ RTP - DISTRIBUIÇÃO - ABR. DE 2005 & $1926-2000$ & 75 & $7,76 \%$ \\
\hline $1^{\text {a }}$ RTP - TRANSMISSÃ̃ - MAI. DE 2007 & $1928-2006$ & 79 & $6,09 \%$ \\
\hline $2^{\mathrm{a}}$ RTP - DISTRIBUIÇÃO - MAR. DE 2007 & $1928-2006$ & 79 & $6,09 \%$ \\
\hline $1^{\mathrm{a}}$ RTP - TRANSMISSÃO - DEZ. DE 2008 & $1928-2008$ & 81 & $5,54 \%$ \\
\hline $3^{\mathrm{a}}$ RTP - DISTRIBUIÇÃO - OUT. DE 2011 & $1928-2010$ & 83 & $5,82 \%$ \\
\hline $3^{\mathrm{a}}$ RTP - TRANSMISSÃO - MAI. DE 2013 & $1928-2012$ & 85 & $5,79 \%$ \\
\hline $1^{\mathrm{a}}$ RTP - GERAÇÃO - MAR. DE 2014 & $1928-2012$ & 85 & $5,79 \%$ \\
\hline 4 a RTP - DISTRIBUIÇÃO - JAN. DE 2015 & Out/1984 - Set/2014 & 30 & $7,56 \%$ \\
\hline
\end{tabular}

\footnotetext{
${ }^{12}$ Fonte: http://www.ftse.com/Analytics/FactSheets/Home/DownloadSingleIssue/GAE?issueName=AWORLDS

${ }^{13}$ Fonte: https://exame.abril.com.br/mercados/as-20-maiores-bolsas-do-mundo/
} 
Conforme (ANEEL, 2018), observa-se uma mudança no número de anos do histórico a partir de 2015, motivado pela substituição da série de retorno de mercado anteriormente utilizada por outra que inclui o reinvestimento dos dividendos.

Como o prêmio de risco de mercado considerado é referente ao mercado norte americano, de alguma forma o risco do país da moeda com a qual o valuation está sendo realizado deve ser considerado. Não existe um consenso quanto a melhor metodologia para tal. Conforme (ANEEL, 2018), a ANEEL tradicionalmente utiliza o Emerging Market Bond Index plus Br (EMBI+ Br), índice calculado pelo banco J.P. Morgan para o Brasil.

Para mercados emergentes como o Brasil, onde ainda não considera possível extrair informações a partir dos dados históricos, Damodaran sugere como referência para o prêmio de risco de mercado, somar à um prêmio de risco de mercado maduro o risco de default do país em que o mercado está. Conforme (DAMODARAN, 2018), existem pelo menos três formas de se definir o prêmio de risco de um ativo (considerando que Prêmio de Risco do Ativo = Prêmio de Risco para um Mercado Maduro + Prêmio de Risco País):

\footnotetext{
“A primeira delas é utilizar o rating soberano atribuído por agências de rating. A segunda é subscrever a serviços que venham com mais amplas medidas de risco país que explicitem fatores de risco econômicos, políticos e legais individualmente para cada país. A terceira é uma medida baseada em questões de mercado como volatilidade de mercados ou da moeda do país."14
}

Em (DAMODARAN, 2018), o autor faz uma atualização de suas premissas para o cálculo do risco país de diferentes nações. Segundo o Autor, com a expansão dos investimentos em países emergentes torna-se necessário que o risco país seja considerado na composição do WACC.

\subsubsection{Estrutura de Capital}

Outro ponto relevante para a definição do WACC é a estrutura de capital desejada para o investimento. Conforme (ANEEL, 2018), dentro da metodologia WACC, ao ser ponderado pela estrutura de capital regulatória o valor definido para o custo de capital de terceiros representa entre $60 \%$ e $48,76 \%$ do custo de capital total, conforme últimas deliberações da ANEEL.

\footnotetext{
${ }^{14}$ Tradução livre do texto em inglês: "The first is the sovereign rating attached to a country by ratings agencies. The second is to subscribe to services that come up with broader measures of country risk that explicitly factor in the economic, political and legal risks in individual countries. The third is go with a market-based measure such as the volatility in the country's currency or markets."
} 
Tabela 4: Histórico das Decisões da ANEEL sobre a Participação do Custo de Capital de Terceiros na Estrutura de Capital Regulatória.

\begin{tabular}{|c|c|}
\hline REVISÃO - SEGMENTO - DATA & \% DÍVIDA \\
\hline 1a $^{\mathrm{a}}$ RTP - DISTRIBUIÇÃO - ABR. DE 2005 & $50 \%$ \\
\hline 1 $^{\text {a }}$ RTP - TRANSMISSÃO - MAI. DE 2007 & $50,4 \%$ \\
\hline 2a RTP - DISTRIBUIÇÃO - MAR. DE 2007 & $57,16 \%$ \\
\hline $1^{\mathrm{a}}$ RTP - TRANSMISSÃO - DEZ. DE 2008 & $63,55 \%$ \\
\hline $3^{\text {a }}$ RTP - DISTRIBUIÇÃO - OUT. DE 2011 & $55 \%$ \\
\hline $3^{\text {a }}$ RTP - TRANSMISSÃO - MAI. DE 2013 & $60 \%$ \\
\hline $1^{a}$ RTP - GERAÇÃO - MAR. DE 2014 & $50 \%$ \\
\hline $4^{\text {a }}$ RTP - DISTRIBUIÇÃO - JAN. DE 2015 & $48,76 \%$ \\
\hline
\end{tabular}

Fonte: ANEEL

Como, por definição, os segmentos regulatórios avaliados na tabela acima são muito diferentes de um gerador privado de energia elétrica, buscou-se uma alternativa. Para a estrutura de capital deste trabalho será utilizado o valor calculado pelo por Damoradan e apresentado na tabela abaixo, para o setor de geração de energia elétrica, que tem por base 64 empresas de 21 países.

\begin{tabular}{|l|l|r|r|r|r|r|}
\cline { 5 - 7 } & \multicolumn{1}{c|}{$\begin{array}{c}\text { Tamanho } \\
\text { Setor de interesse }\end{array}$} & $\begin{array}{c}\text { Número } \\
\text { países }\end{array}$ & $\begin{array}{c}\text { Razão } \\
\text { D/E }\end{array}$ & $\%$ D & $\%$ E \\
\hline Aeroportos & Air Transport & 155 & 55 & $26 \%$ & $\mathbf{2 1 \%}$ & $\mathbf{7 9 \%}$ \\
\hline Ferrovias & Transportation (Railroads) & 51 & 15 & $0 \%$ & $\mathbf{0} \%$ & $\mathbf{1 0 0} \%$ \\
\hline Portos & Shipbuilding \& Marine & 342 & 59 & $40 \%$ & $\mathbf{2 9} \%$ & $\mathbf{7 1 \%}$ \\
\hline Rodovias & Transportation & 235 & 47 & $0 \%$ & $\mathbf{0} \%$ & $\mathbf{1 0 0} \%$ \\
\hline Geração E. E. & Power & 64 & 21 & $65 \%$ & $\mathbf{3 9} \%$ & $\mathbf{6 1 \%}$ \\
\hline
\end{tabular}

Fonte: Damodaran - Janeiro de 2018.

Figura 17: Estrutura de Capital para diferentes setores da economia. Fonte: Ministério da Fazenda ${ }^{15}$

Com relação à estrutura de capital, é importante ponderar que, quanto maior o endividamento, maior o risco no sentido financeiro, devido à maior alavancagem. Contudo, a maior participação de dívida se apresenta como uma solução mais econômica para a empresa do que a remuneração exigida pelos investidores, devido ao benefício fiscal que possui. Nesse sentido, existem teorias que discutem qual é a composição ótima de financiamento em proporções de dívida e equity (capital próprio ou do investidor).

Dentre algumas teorias, para a definição da estrutura de capital ideal, pode-se citar como exemplo, a 'Teoria de Modigliani e Miller', desenvolvida nos anos 50, e exposta em (MODIGLIANI e MILLER, 1958), a qual defende que o valor da empresa independe da estrutura de capital adotada; não obstante, baseado na inexistência de imposto de renda, de custo de dificuldade financeira (ou distress cost) e considerando a possibilidade de

\footnotetext{
15 (MINISTÉRIO DA FAZENDA, 2018)
} 
'home leverage', que seria a possibilidade de captar recursos no mercado pagando o mesmo custo da taxa de juros da própria empresa. Posteriormente, em 1963, os autores passam a considerar a existência de imposto de renda e como isso pode beneficiar a estrutura de capital.

\subsection{Custo de Investimento}

\section{Hidrelétricas}

O gráfico abaixo expõe a análise dos valores de investimento declarados nos LEN promovidos pelo governo brasileiro desde o ano de 2005. A média dos preços no período observado também está exposta no gráfico:

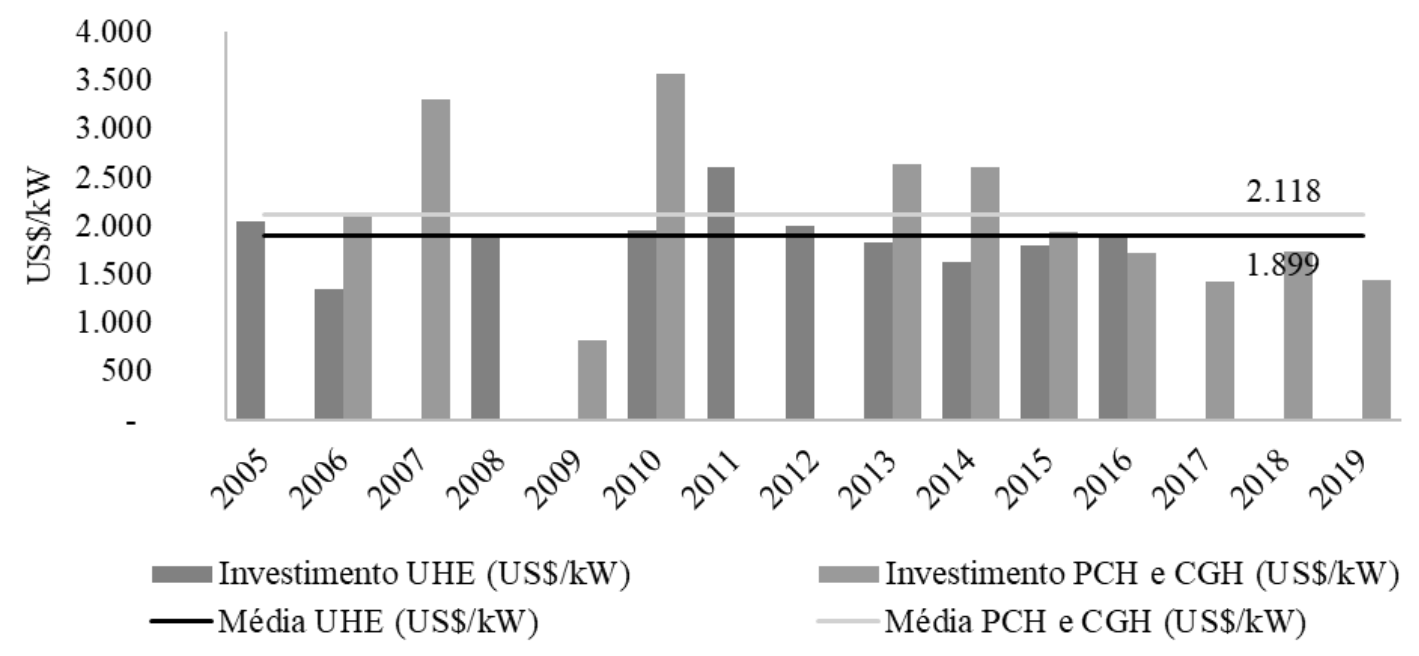

Figura 18: Custo de Investimento em Hidrelétricas nos Leilões Regulados.

Fonte: Autora

A seguir são comparados valores obtidos com base nas referências bibliográficas (IRENA, 2019), (EPE, 2018), (EPE, 2019b).

Como referência para o custo das hidrelétricas de maior porte descritos na figura 19 , foi utilizado a tabela de projetos disponível em (EPE, 2019b). 


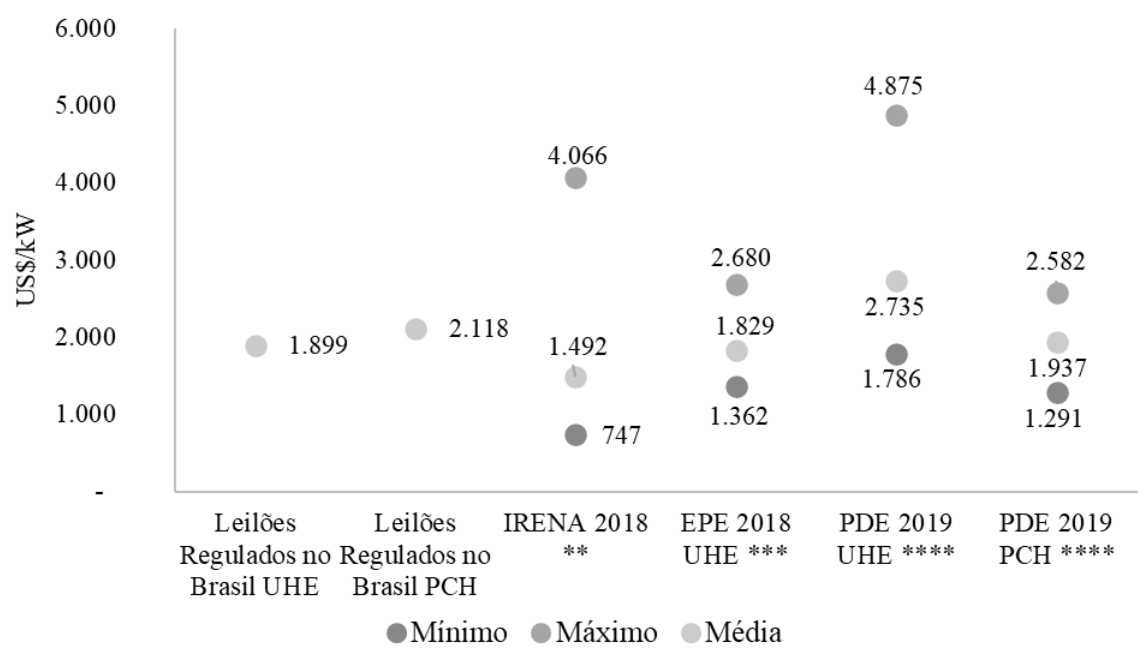

Figura 19: Custo de Investimento em UHEs e PCHs com Base em Diferentes Referências ${ }^{16}$ Fonte: Autora

\begin{tabular}{|c|c|c|c|c|}
\hline UHE & Potência & $\begin{array}{l}\text { Encargos/ } \\
\text { Impostos }\end{array}$ & $\begin{array}{c}\text { Juros } \\
\text { durante a } \\
\text { Construção } \\
\text { (JDC) }\end{array}$ & $\begin{array}{c}\text { CAPEX } \\
\text { considerado, } \\
\text { incluindo JDC }\end{array}$ \\
\hline & MW & $\mathbf{R} \mathbf{\text { /KW } / \text { ano }}$ & $\%$ & $\mathbf{R} \$ / \mathbf{k W}$ \\
\hline Apertados & 138,9 & 500 & $12,6 \%$ & $9.387,66$ \\
\hline Bem Querer & 650,0 & 500 & $12,5 \%$ & $9.346,28$ \\
\hline Buriti Queimado & 142,0 & 620 & $12,5 \%$ & $16.175,90$ \\
\hline Castanheira & 140,0 & 620 & $12,5 \%$ & $12.521,22$ \\
\hline Comissário & 140,1 & 500 & $12,5 \%$ & $11.016,00$ \\
\hline Davinópolis & 74,1 & 620 & $12,5 \%$ & $14.474,37$ \\
\hline Ercilândia & 87,1 & 500 & $12,5 \%$ & $10.918,11$ \\
\hline Formoso & 342,0 & 620 & $12,5 \%$ & $12.132,92$ \\
\hline Foz do Piquiri & 93,3 & 500 & $12,5 \%$ & $11.564,33$ \\
\hline Foz do Xaxim & 63,2 & 500 & $12,5 \%$ & $10.160,68$ \\
\hline Itaguaçu & 92,0 & 400 & $12,6 \%$ & $7.420,88$ \\
\hline Itapiranga & 724,5 & 400 & $12,6 \%$ & $8.310,04$ \\
\hline Jatobá & 1650,0 & 500 & $10,3 \%$ & $8.406,76$ \\
\hline Maranhão & 125,1 & 500 & $12,5 \%$ & $9.889,63$ \\
\hline Mirador & 80,0 & 500 & $12,5 \%$ & $10.249,11$ \\
\hline Paranã & 90,0 & 500 & $12,5 \%$ & $9.757,44$ \\
\hline Porteiras & 86,0 & 620 & $12,5 \%$ & $18.878,46$ \\
\hline Porto Galeano & 81,0 & 400 & $12,5 \%$ & $8.109,29$ \\
\hline Santo Antônio & 84,3 & 400 & $12,5 \%$ & $6.916,14$ \\
\hline Saudade & 61,4 & 500 & $12,5 \%$ & $9.371,24$ \\
\hline Tabajara & 400,0 & 500 & $12,5 \%$ & $9.978,35$ \\
\hline Telêmaco Borba & 118,0 & 400 & $12,5 \%$ & $8.064,44$ \\
\hline
\end{tabular}

Figura 20: Parâmetros Econômicos das UHEs Consideradas. Fonte: (EPE, 2019b)

\footnotetext{
$16 *$ Preços referenciados em 2018.

** Preços referenciados em 2015 com um dólar de US\$ 3,873.

*** Considera o dólar de US\$ 3,88.
} 


\section{Termelétricas a Gás Natural}

Para as termelétricas movidas a gás natural, a mesma análise de anterioridade foi feita, observando os leilões regulados de energia elétrica realizados. O resultado está exposto no gráfico da figura a seguir:

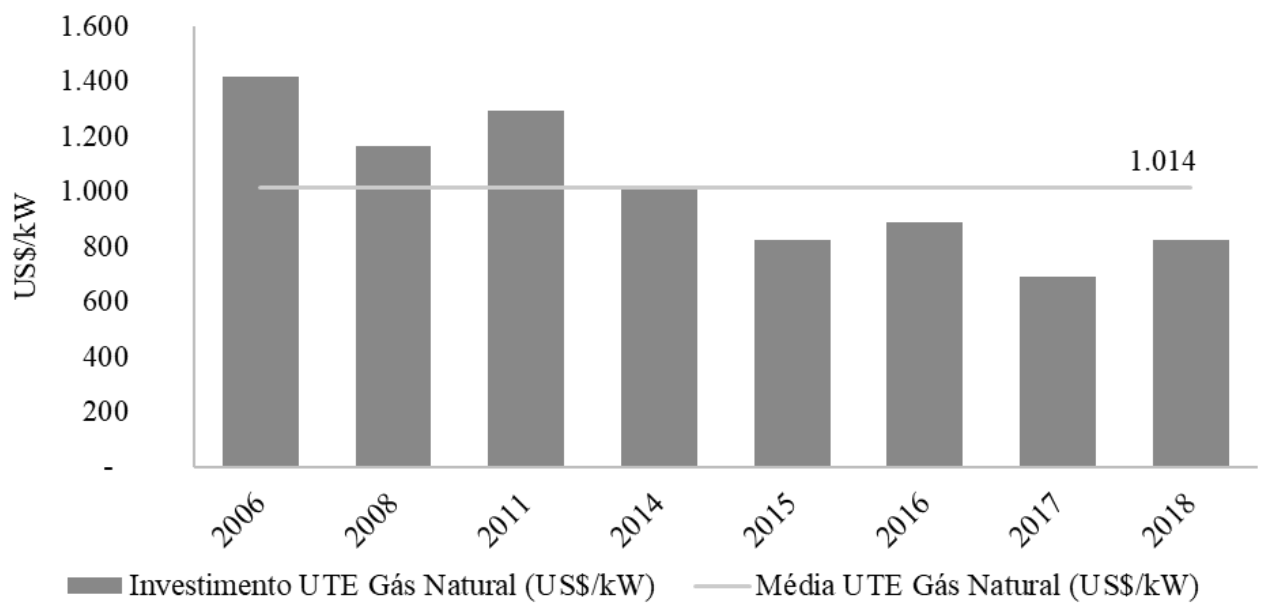

Figura 21: Custo de Investimento em Termelétricas movidas a Gás Natural nos Leilões Regulados.

Fonte: Autora

A seguir, são comparados os valores obtidos com base nas referências bibliográficas, (EPE, 2018), (EPE, 2019b).

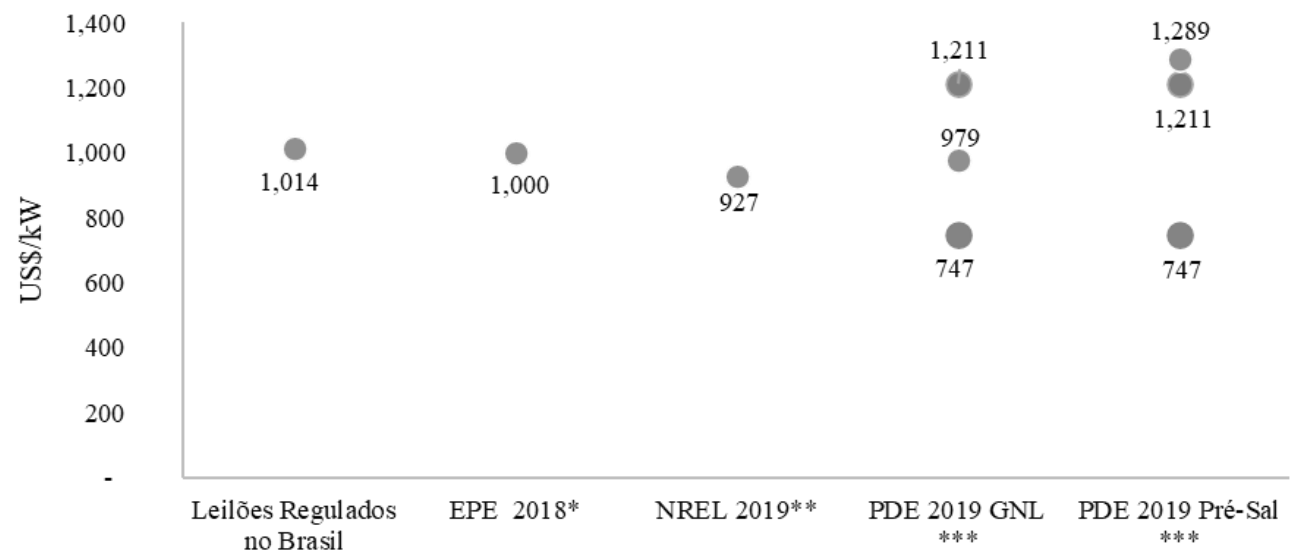

* Custo de Investimento para UTE de Ciclo Combinado

Figura 22: Custo de Investimento em Termelétricas Movidas a Gás Natural de Ciclo Combinado com Base em Diferentes Referências ${ }^{17}$

Fonte: Autora

\footnotetext{
17 * Considera o dólar de US\$3,873

** Fonte: https://atb.nrel.gov/electricity/2019/index.html?t=cg

*** Considera o dólar de US\$ 3,88; O CAPEX do projeto GNL médio considera o custo do terminal de regaseificação; O CAPEX do projeto Pré-sal considera o custo do gasoduto de escoamento.
} 


\section{Eólicas}

Para a geração eólica, a mesma análise de anterioridade foi feita, observando os leilões regulados de energia elétrica realizados. O resultado está exposto no gráfico da figura a seguir:

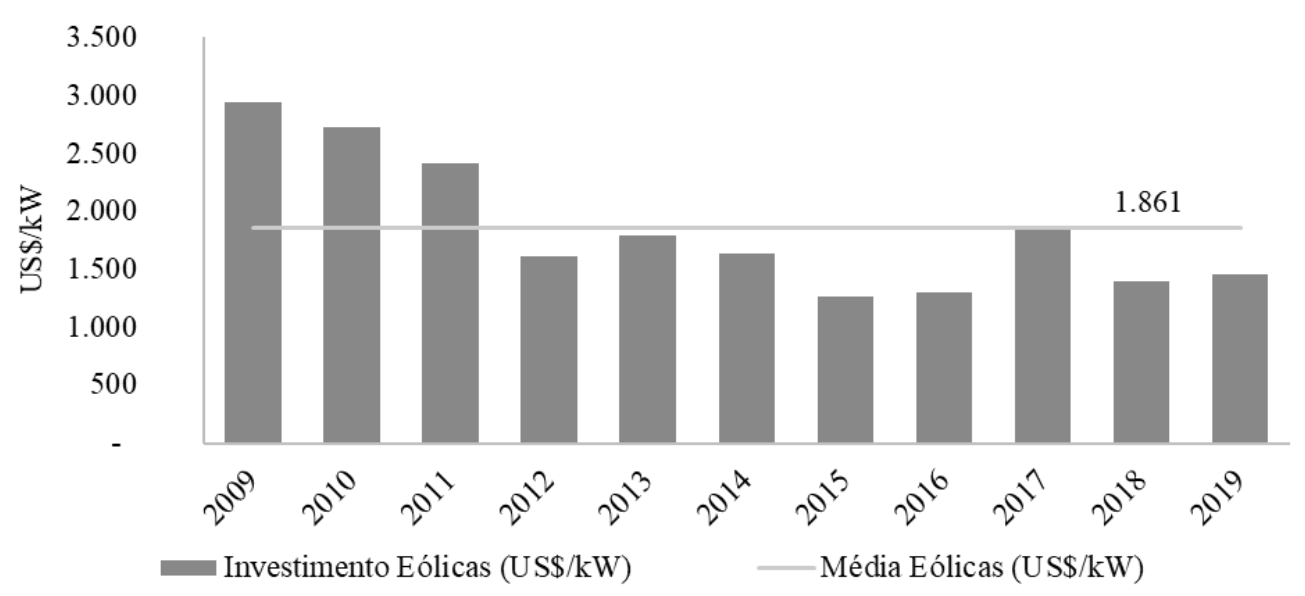

Figura 23: Custo de Investimento em Plantas Eólicas nos Leilões Regulados

Fonte: Autora

Abaixo comparam-se os valores obtidos com base nas referências bibliográficas (IRENA, 2019), (EPE, 2018), (EPE, 2019b):

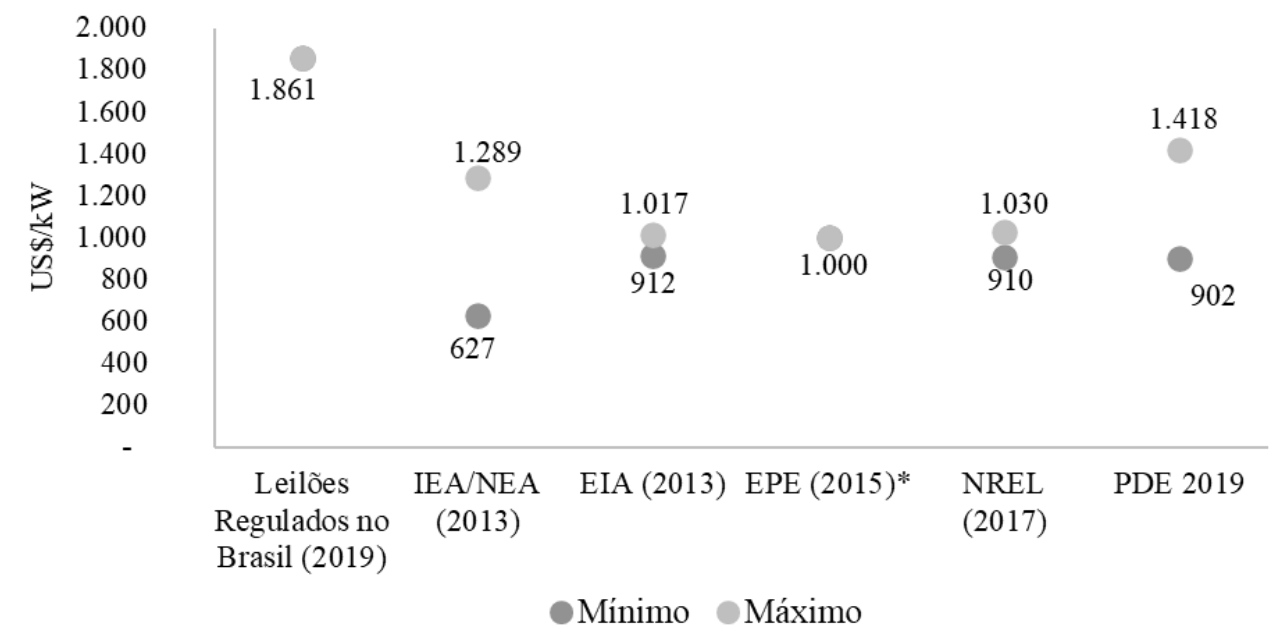

Figura 24: Custo de Investimento em Eólicas com Base em Diferentes Referências ${ }^{18}$

Fonte: Autora

\footnotetext{
18 * Preços referenciados em 2015 com um dólar de US\$ 3,873.

** Preços referenciados em 2018.

*** Considera o dólar de US\$3,88.
} 


\section{$\underline{\text { Solar }}$}

Para a geração solar, a mesma análise de anterioridade foi feita, observando os leilões regulados de energia elétrica realizados. O resultado está exposto no gráfico da figura a seguir:

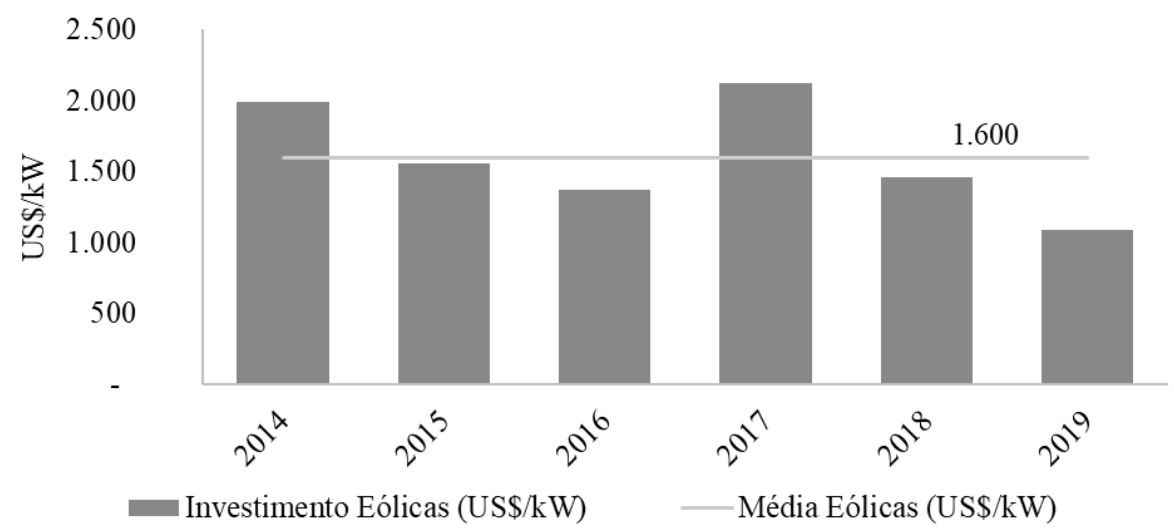

Figura 25: Custo de Investimento em Plantas Solares nos Leilões Regulados Fonte: Autora

Abaixo comparam-se os valores obtidos com base nas referências bibliográficas (IRENA, 2019), (EPE, 2018), (EPE, 2019b):

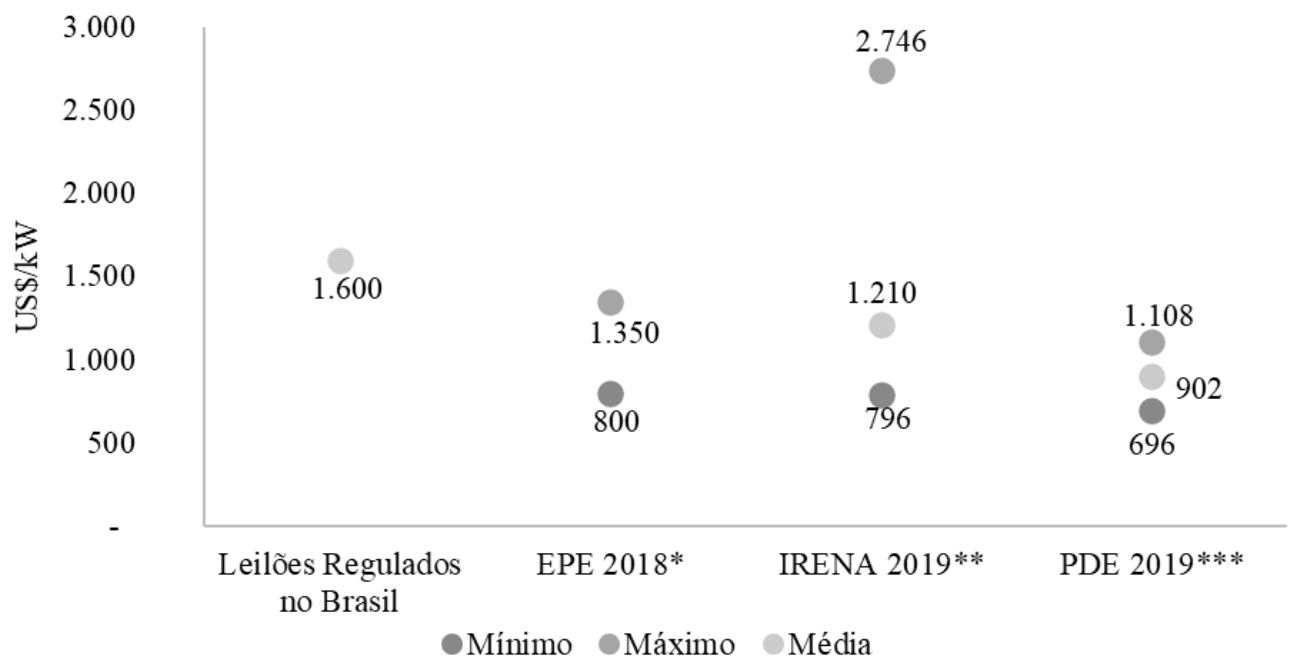

Figura 26: Custo de Investimento em Eólicas com Base em Diferentes Referências ${ }^{19}$

Fonte: Autora

\footnotetext{
19 * Considera um dólar de US\$ 3,873.

** Preços referenciados em 2018

*** Considera o dólar de US\$3,88
} 
Destaca-se a seguir um gráfico apresentado em (EPE, 2018) para a evolução do custo de investimento em energia solar. Conforme as informações, os custos de investimento em sistemas fotovoltaicos devem se reduzir 30\% entre os anos de 2020 e 2050 .

Custo de Investimento em Sistema Fotovltáico (US\$/kWac)

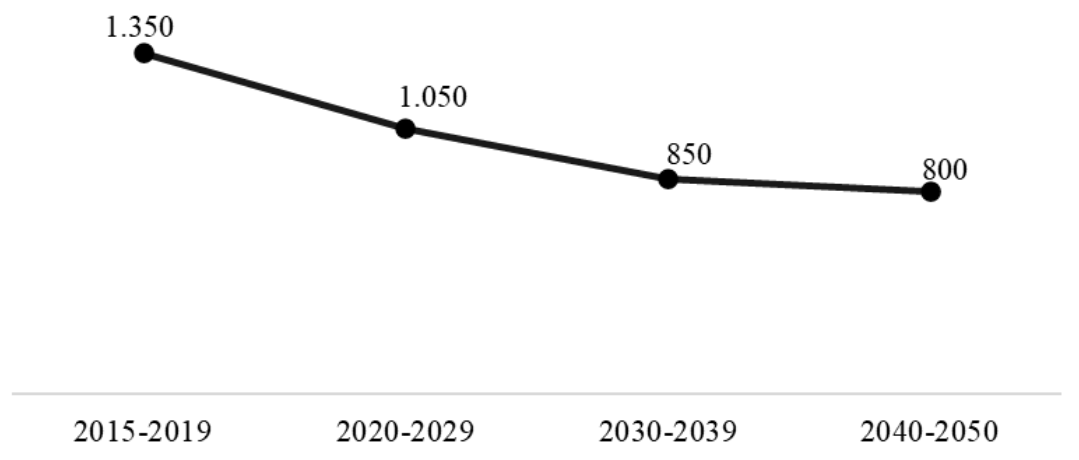

Figura 27: Evolução Prevista do Custo de Investimento em Sistemas Fotovoltaicos ${ }^{20}$ Fonte: Autora

\section{$\underline{\text { Biomassa }}$}

Para a geração movida a biomassa, a mesma análise de anterioridade foi feita, observando os leilões regulados de energia elétrica realizados. O resultado está exposto no gráfico da figura a seguir.

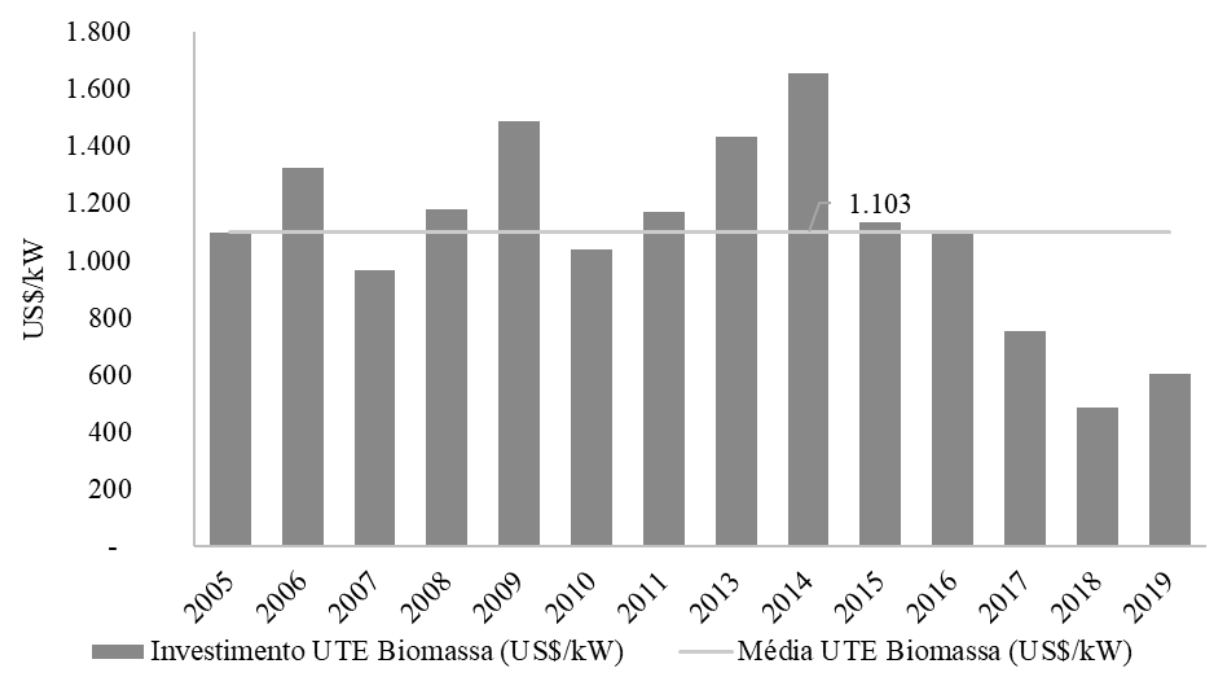

Figura 28: Custo de Investimento em Plantas Movidas a Biomassa nos Leilões Regulados Fonte: Autora

\footnotetext{
20 Fonte: Elaboração própria a partir de GTM Research (2018), LEN A-4 - (2017 e 2018), Irena (2016) e IEA (2014)
} 
Na Figura que se segue comparam-se os valores obtidos com base nas referências bibliográficas (IRENA, 2019), (EPE, 2018), (EPE, 2019b).

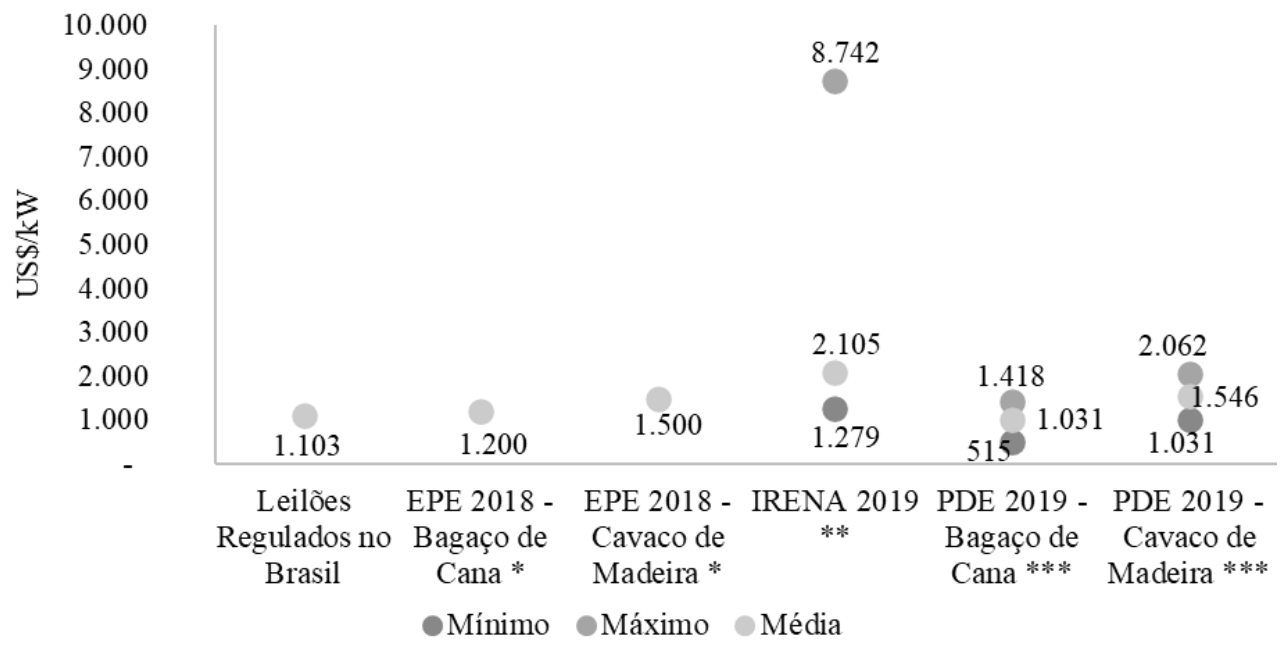

Figura 29: Custo de Investimento em Biomassa com Base em Diferentes Referências ${ }^{21}$

Fonte: Autora

\subsection{Custo de Operação \& Manutenção}

\section{Hidrelétricas}

Para as usinas hidrelétricas, (EPE, 2018) expõe valores de custos de operação e manutenção de $\mathrm{R}$ \$ 30/kW/ano, para usinas com potência até 300MW e R\$ 50/kW/ano para usinas com potência superior à 300MW. Conforme o relatório:

“[...] os custos de operação e de manutenção compreendem os gastos com pessoal, material de consumo e equipamentos (exclusive reposição e reparos de grande monta nos equipamentos permanentes principais da usina) necessários à operação normal da usina e do sistema de transmissão associado (conexão) ${ }^{22}$ "

(EPE, 2018) ainda aponta dados da literatura internacional, divulgados em (USEIA, 2013), entre $14 \mathrm{US} \$ / \mathrm{kW} /$ ano para usinas de grande porte (500 MW) e de 18 US\$/KW/ano para usinas hidrelétricas reversíveis (250 MW). Para as PCHs, a (EPE, 2019b) aponta o custo de O\&M na casa dos R \$90/MWh.

\footnotetext{
$21 *$ Considera um dólar de US\$ 3,873.

** Preços referenciados em 2018.

*** Considera o dólar de US\$ 3,88 .

${ }^{22}$ Existem poucos dados disponíveis a respeito dos custos operacionais de UHEs, mas usinas de menor porte devem apresentar custos unitários de operação e manutenção mais elevados. De qualquer modo, a importância relativa desses custos na composição do custo total da geração hidrelétrica é pequena.
} 
Tabela 5: Custos de O\&M para a geração hidrelétrica.

\begin{tabular}{c|cc} 
Referência & Custo de O\&M Fixo & Custo de O\&M Variável \\
EPE $(2018)^{23}($ até $300 M W /$ maior que $300 M W)$ & $30 / 50 \mathrm{R} \$ / \mathrm{kW} /$ ano & - \\
EIA-US $(2013)^{24}$ & $54^{25} \mathrm{R} \$ / \mathrm{kW} / \mathrm{ano}$ & - \\
EPE $(2016)^{26}$ & $50 \mathrm{R} \$ / \mathrm{kW} / \mathrm{ano}^{27}$ & $7 \mathrm{R} \$ / \mathrm{MWh}^{28}$
\end{tabular}

Fonte: Autora

(IRENA, 2018), por outro lado, aponta custos de operação e manutenção como um percentual do custo de investimento total em $\mathrm{kW}$ por ano. Segundo a agência, valores típicos variam entre 1 e 4\%. O material ainda cita a International Energy Agency (IEA), com custos de 2,2\% para usinas hidrelétricas de grande porte e custos variando entre 2,2\% e $3 \%$ para usinas de menor porte, sendo a média global na casa de $2,5 \%$. O material cita também como referência dados da Energy Information Agency (EIA), com custos anuais fixos de $0,06 \%$ do total instalado e 0,003 USD/MWh de custo de O\&M variável.

\section{Termelétrica movida a Gás Natural}

Para as termelétricas movidas a gás natural, (EPE, 2018) divide os custos de O\&M entre custos fixos e variáveis, sendo os fixos aqueles que não variam significativamente com a produção de eletricidade, e os variáveis aqueles que são função da quantidade de eletricidade gerada. Os custos fixos incluem custos de mão-de-obra, encargos mensais, despesas gerais e administrativas e manutenção programada. Já os custos variáveis incluem o consumo de água e lubrificantes e outros insumos necessários, assim como também custos com manutenções periódicas por conta das horas de operação da máquina, como overhauls. Os dados divulgados por (EPE, 2018), para termelétricas de ciclo combinado que são o objeto de estudo aqui, encontram-se na tabela que se segue:

Tabela 6: Custos de O\&M para a geração termelétrica a gás natural de ciclo combinado. Fonte: EPE

\begin{tabular}{c|cc} 
Referência & Custos Fixos (US\$/kW.ano) & Custos Variáveis (US\$/MWh) \\
\hline OECD/NEA/IEA (2015) & $9-26$ & $2,00-3,70$ \\
DECC $(2013)^{30}$ & $15,0-34,90$ & 0,15 \\
US-EIA $(2015)^{31}$ & $13,15-15,30$ & $3,30-3,60$ \\
NREL $(2017)^{32}$ & $6,30-12,0$ & $3,00-3,70$
\end{tabular}

\footnotetext{
${ }^{23}$ (EPE, 2018)

${ }^{24}$ EIA - U.S. Energy Information Administration. Updated Capital Cost Estimates for Utility Scale Electricity Generating Plants. U.S. Energy Information Administration. Washington, DC 20585. 2013.

${ }^{25}$ Considera um dólar médio em $\mathrm{R} \$ 3,84$.

${ }^{26}$ (TOLMASQUIM, 2016)

${ }^{27}$ Considera um dólar médio em $\mathrm{R} \$ 3,84$.

${ }^{28}$ Considera um dólar médio em $\mathrm{R} \$ 3,84$.

${ }^{29}$ OECD - Organization for Economic Co-Operation and Development, NEA - Nuclear Energy Agency, IEA - International Energy Agency. Projected Costs of Generating Electricity - 2010 Update.

${ }^{30}$ Não encontrado em (EPE, 2018).

${ }^{31}$ EIA - U.S. Energy Information Administration. U.S. Natural Gas Gross Withdrawals and Production. Independent Statistics \& Analysis, 2015.

${ }^{32}$ NREL. National Renewable Energy Laboratory. Annual Technology Baseline. 2017. Disponível em: https://atb.nrel.gov/
} 
Para estimar o custo de combustível gás natural e entender sua variação, também observou-se os heat rates típicos de plantas movidas a gás natural, divulgados pela EIA, como também o custo do GNL importado no Brasil divulgado no Boletim do Gás Natural do MME. Conforme (EIA, 2018), o heat rate verificado para plantas movidas a gás natural com ciclo combinado nos últimos anos foi conforme segue na Tabela 7:

Tabela 7: Heat rate médio testado para o combustível gás natural em planta de ciclo combinado.

\begin{tabular}{|c|c|}
\hline ANO & HEAT RATE (BTU/KWH) \\
\hline $\mathbf{2 0 0 7}$ & 7.577 \\
$\mathbf{2 0 0 8}$ & 7.642 \\
$\mathbf{2 0 0 9}$ & 7.605 \\
$\mathbf{2 0 1 0}$ & 7.619 \\
$\mathbf{2 0 1 1}$ & 7.603 \\
$\mathbf{2 0 1 2}$ & 7.615 \\
$\mathbf{2 0 1 3}$ & 7.667 \\
$\mathbf{2 0 1 4}$ & 7.658 \\
$\mathbf{2 0 1 5}$ & 7.655 \\
$\mathbf{2 0 1 6}$ & 7.652 \\
\hline
\end{tabular}

Fonte: EIA

Além disso, conforme (MME, 2019) e (MME, 2015), o preço do GNL praticado no Brasil nos últimos anos evoluiu da seguinte maneira (Figura 30):

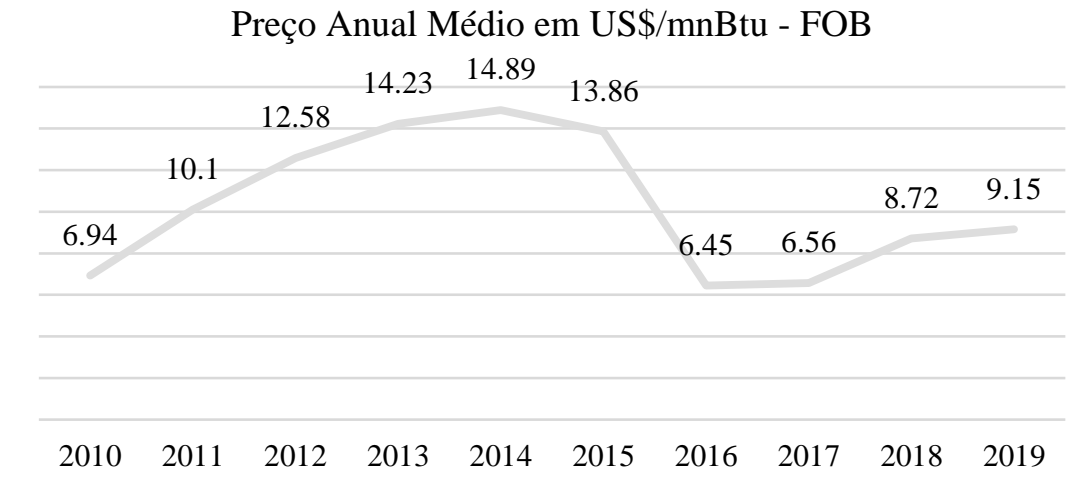

Figura 30: Preço Anual Média do GNL importado no Brasil em US\$/mnBtu.

Fonte: Autora

Por estes dados conseguimos calcular o preço médio do GNL no Brasil em R\$/MWh conforme ilustra o gráfico da Figura 31 que segue.

Com relação aos custos do gás advindo do Pré-sal, avaliou-se o estudo (EPE, 2019a), que avalia o break-even dos projetos, simulando fluxos de caixa, tendo por base nas informações de custos de investimento e de operação coletadas na literatura, assim como os parâmetros operacionais típicos de E\&P, escoamento e processamento. 
Preço Anual Médio em R \$MWh - FOB

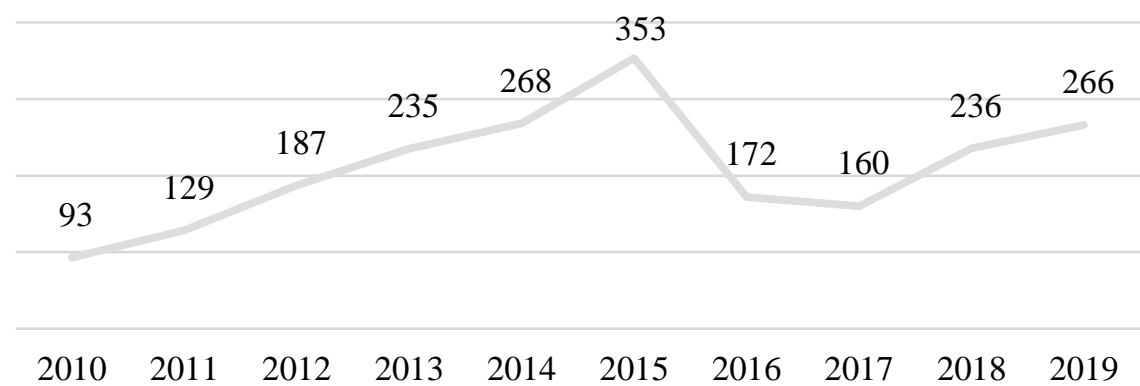

Figura 31: Preço Anual Médio do GNL importado no Brasil em R \$MWh

Fonte: Autora

A Figura 32 ilustra os resultados do estudo.

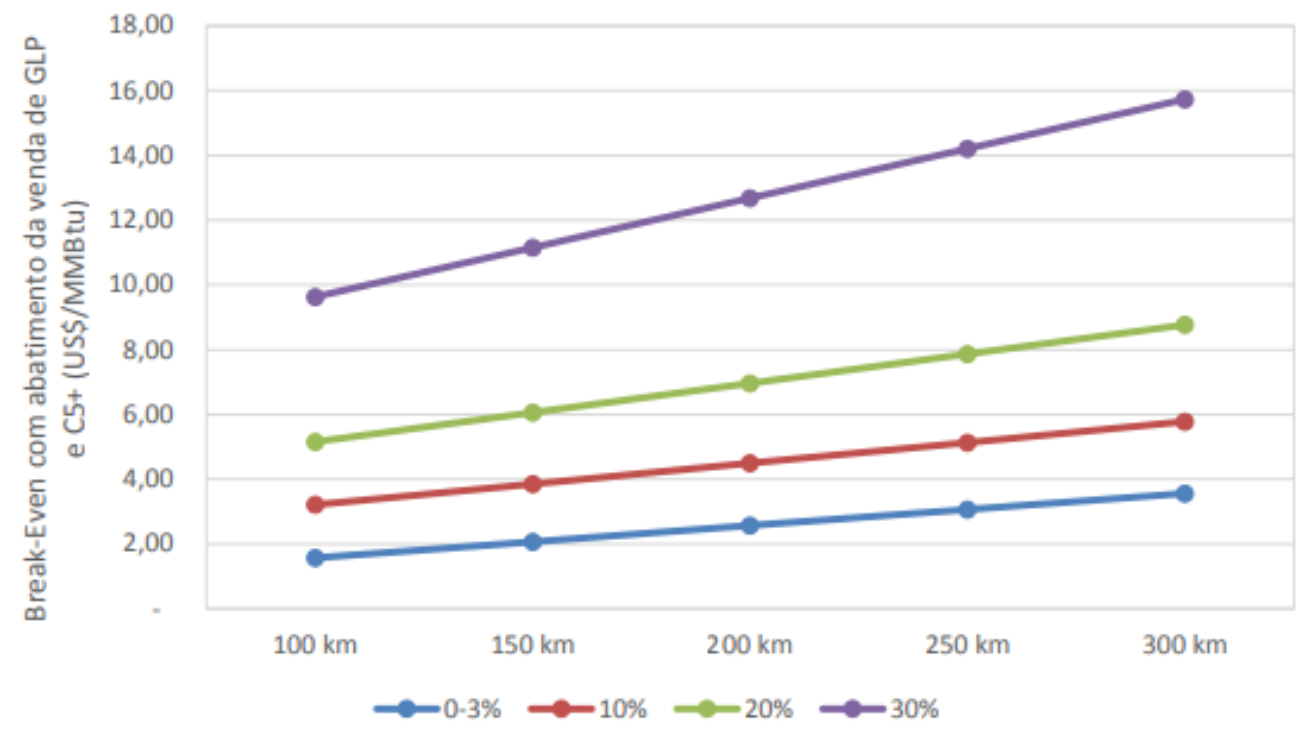

Figura 32: Estimativas de break-even do gás natural do Pré-sal. Fonte: (EPE, 2019a)

O estudo realizado apresenta os custos de break-even, considerando a distância do local de exploração até a costa e o teor de $\mathrm{CO}_{2}$ das amostras. Destaca-se também que o estudo desconsidera o fluxo de caixa da parte referente ao petróleo, portanto não havendo transferência de lucros entre diferentes partes do projeto. Além disso, os resultados apresentados na Figura 32, consideram o abatimento da receita obtida com GLP ${ }^{33}$ e C5+ ${ }^{34}$ do preço do gás natural especificado.

\footnotetext{
${ }^{33}$ GLP: O gás liquefeito de petróleo (GLP) é popularmente conhecido como gás de botijão ou gás de cozinha, e sua queima proporciona baixo nível de emissões. Essencialmente composto por dois gases extraídos do petróleo, o butano e o propano, pode também conter, minoritariamente, outros hidrocarbonetos, como o etano. Fonte: Agência Nacional do Petróleo (ANP), Sítio Eletrônico: http://www.anp.gov.br/petroleo-e-derivados2/glp, Acessado em: 24 de setembro de 2019.

${ }^{34}$ C5+ é a abreviação técnica para gasolina natural. Fonte: (EPE, 2019a)
} 
Conforme (EPE, 2019a), os estudos indicam:

"Os resultados da análise econômica permitiram concluir que, com base nos parâmetros adotados, os valores de Break-even do gás Natural podem variar de US\$1,60 a cerca de US\$ 16,00 /MMBtu, para vários teores de $\mathrm{CO} 2$ e distâncias entre o campo produtor e o litoral, no cenário em que sejam realizados abatimentos referentes aos valores da comercialização do GLP e C5+ dos preços finais do gás natural. No caso de não serem abatidos dos preços de gás natural os valores obtidos pela venda do GLP e do C5+, as estimativas de Break-Even têm um aumento de cerca de US\$ 4,30 /MMBtu. Para que o gás natural do Pré-Sal tenha um Break-Even próximo ao valor da molécula vendida em 2018 no Brasil, de US\$ 6,50 a US\$ 8,50 /MMBtu (MME, 2019), este deve ter um teor de CO2 de até cerca de $20 \%$."

\section{Eólicas}

Para as usinas eólicas, a IRENA em (IRENA, 2018), aponta que apesar dos custos de O\&M estarem muitas vezes disponíveis, não necessariamente são uniformes com relação ao que se considera na sua composição. A agência aponta que contratos de O\&M do tipo 'full service', contratados desde o início da operação comercial das plantas, costumam variar entre US\$ 14 e US\$30/kW/ano, quando avaliado o período entre 2008 e 2017. Já a renovação destes contratos, do tipo 'full-service', costumam variar entre US\$ 22 e USD 44/kW/ano. A Figura 33 ilustra estes custos de O\&M:

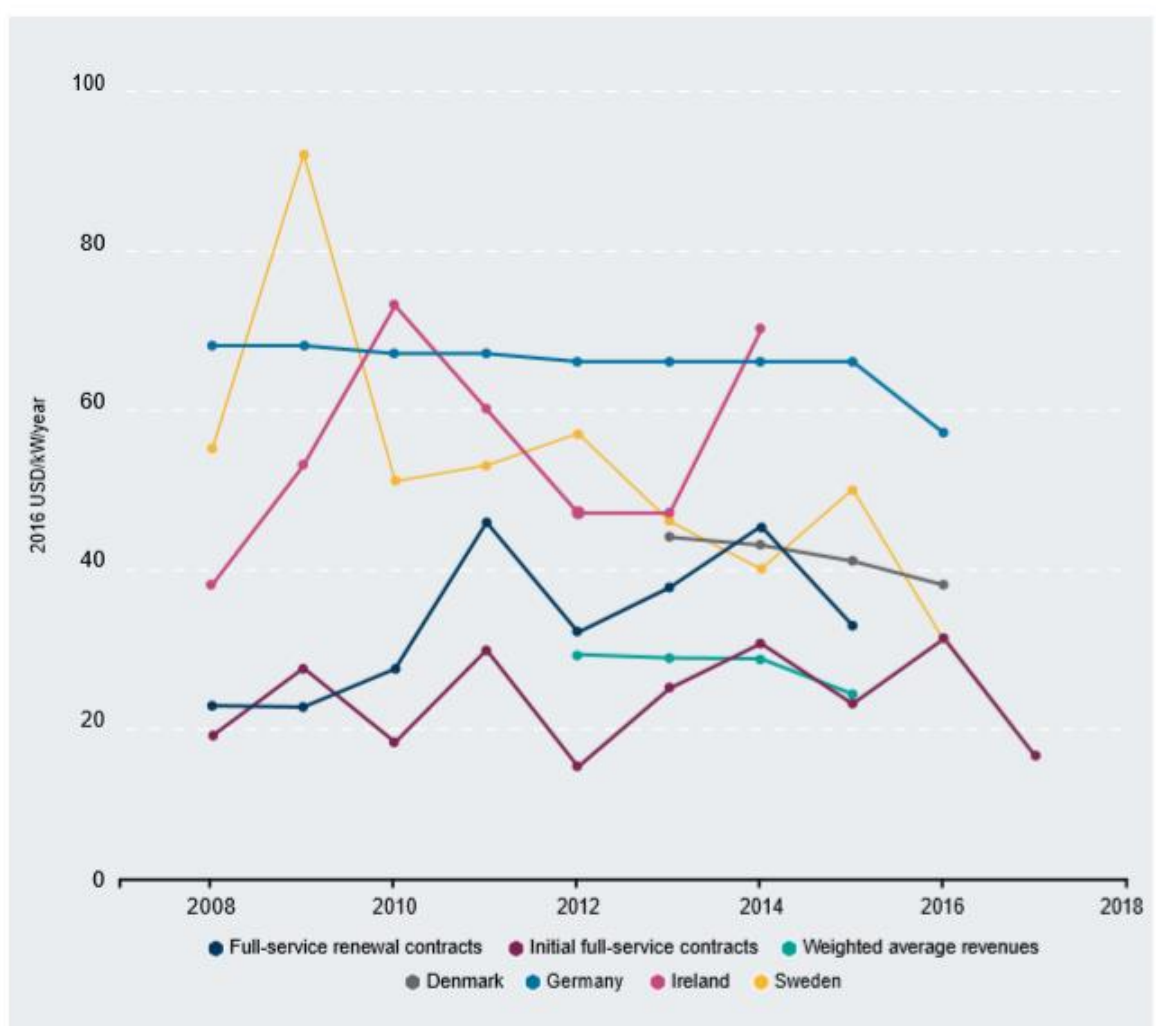

Figura 33: Contratos de O\&M tipo "full service" (iniciais e renovação), média ponderada da receita de O\&M de dois produtores e custos de O\&M na Dinamarca, Alemanha, Irlanda e Suécia entre 2008 e 2017. 
A EPE em (EPE, 2018), expõe um custo único de O\&M e fixo de US\$100/kW/ano, para plantas com uma vida útil de 20 anos e fatores de capacidade de $40 \%$, quando as plantas estão localizadas no Sul e Sudeste e de $47 \%$ quando as plantas estão localizadas no Norte ou Nordeste.

Tabela 8: Custo de O\&M das eólicas

REFERÊNCIA

EPE (2018) ${ }^{35}$

IRENA (2017) $)^{37}$

EPE (2016) ${ }^{39}$

EPE (2019)
CUSTOS DE O\&M

$384 R \$ / k W / a n o^{36}$

$54-169 R \$ / k_{W} / a n o^{38}$

$85 \mathrm{R} \$ / \mathrm{kW} / \mathrm{ano}$

$90 \mathrm{R} \$ / \mathrm{kW} / \mathrm{ano}$

Fonte: Autora

\section{$\underline{\text { Solar }}$}

Para as usinas solares, a (EPE, 2018) aponta apenas custos fixos de O\&M em R\$ 20/kWp/ano. Já em (EPE, 2019b) o custo fixo de O\&M está estimado em R\$ 50/kW/ano. Quando se observa a literatura internacional, (IRENA, 2018) aponta os custos de O\&M para a geração solar fotovoltaica de grande escala nos Estados Unidos entre US\$ 10 e US\$ 18/kW/ano.

Tabela 9: Custo de O\&M das Usinas Solares Fotovoltaicas

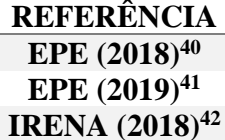

CUSTOS DE O\&M

$20 \mathrm{R} \$ / \mathrm{kWp} / \mathrm{ano}$

$50 R \$ / k W / a n o$

$38,80-69,84 R \$ / k^{2} / a^{43}$

Fonte: Autora

Para as usinas solares fotovoltaicas, o fator de capacidade apresentado em (EPE, 2018) é de $30 \%$ com uma vida útil de 20 anos.

\section{Biomassa}

Para as usinas termelétricas movidas a biomassa, a (EPE, 2018) aponta dos custos fixos de O\&M em R \$90/kW/ano quando a biomassa for do tipo bagaço de cana e aponta $\mathrm{R} \$ 120 / \mathrm{kW} /$ ano quando a biomassa for do tipo cavaco de madeira e residual lenhosa.

\footnotetext{
35 (EPE, 2018)

${ }^{36}$ Considera um dólar médio em $\mathrm{R} \$ 3,84$.

37 (IRENA, 2018)

${ }^{38}$ Considera um dólar médio em $\mathrm{R} \$ 3,84$. Considera o range entre contratos 'full service' do tipo iniciais e renovações.

39 (TOLMASQUIM, 2016)

40 (EPE, 2018)

41 (EPE, 2019b)

42 (IRENA, 2018)

${ }^{43}$ Considera uma relação Real - Dólar de R\$3,88/US\$.
} 
Já (EPE, 2019b) aponta custos semelhantes aos apresentados anteriormente, incluindo o custo fixo estimado para usinas movidas a Biogás em $\mathrm{R} \$$ 500/kW/ano. Quando se observa a literatura internacional, (IRENA, 2018) aponta os custos de O\&M fixo anual entre $2 \%$ e $6 \%$ do custo total instalado, enquanto o custo variável estaria operando na casa dos US\$0,005/kW.

Para as usinas movidas a biomassa do tipo bagaço de cana, a (EPE, 2018) aponta um fator capacidade de $33 \%$, já para os demais tipos aponta fator de capacidade de $80 \%$. A vida útil considerada para os empreendimentos deste tipo é apontada na mesma referência como sendo de 20 anos.

\subsection{Tarifas e Encargos Setoriais}

Os encargos e tarifas setoriais têm por finalidade a remuneração de serviços públicos e o financiamento de políticas públicas no setor elétrico brasileiro sendo criados e aprovados por leis do Congresso Nacional e regulamentados pela ANEEL.

\section{$\underline{\text { Tarifa de Uso do Sistema de Transmissão }}$}

No Brasil, o custo de transmissão das fontes de energia é pago através do Encargo de Uso do Serviço de Transmissão (EUST), o qual é dado pelo produto da Tarifa de Uso do Sistema de Transmissão (TUST) pelo Montante de Uso do Sistema de Transmissão (MUST). A metodologia vigente para o cálculo da TUST leva em consideração tanto um sinal locacional de preços, quanto uma componente de selo, de forma que, através do cálculo realizado pelo Modelo NODAL, a soma desses dois valores, pagos por todos os usuários da linha, venham a remunerar em sua totalidade os investimentos realizados no sistema de transmissão. Como referência para o valor de TUST a ser utilizado na avaliação econômico financeira dos projetos, optou-se por adotar valor próximo aos homologados para a conexão da rede básica do última LEN realizado (A-6 de 2019), conforme exposto em (ANEEL, 2019).

\section{Compensacão Financeira pelo uso de Recursos Hídricos}

A Compensação Financeira pelo Uso de Recursos Hídricos - CFURH corresponde à $6,75 \%$ da produção de valor total de energia mensal produzida por usina em MWh valorada pela Tarifa Anualizada de Referência - TAR. 
Do total arrecadado, são destinados $65 \%^{44}$ aos municípios, $25 \%$ aos estados e os $10 \%$ restantes repassados à União, com a finalidade compensá-los pelo uso da água e das terras produtivas necessárias à instalação da usina.

\section{Pesquisa e Desenvolvimento e Eficiência Energética}

O encargo para Pesquisa e Desenvolvimento e Eficiência Energética - P\&D/EE, tem por objetivo financiar a pesquisas científicas e tecnológica no setor de energia elétrica e uso sustentável dos recursos, devendo corresponder à $1 \%$ da Receita Operacional Líquida. O encargo foi criado originalmente pela Lei 9.991/2000, sendo alterado posteriormente pela Lei 12.212/2010.

\section{$\underline{\text { Tarifa de Fiscalização dos Serviços de Energia Elétrica }}$}

A tarifa de Fiscalização dos Serviços de Energia Elétrica foi criada com o objetivo de custear o funcionamento da ANEEL e suas atividades em fiscalização e regulamentação do setor de energia elétrica no país, sendo criado inicialmente em 1996 pela Lei 9.427 e alterada pela Lei 12.783 em 2013. A tarifa corresponde à $0,4 \%$ do benefício econômico anual dos agentes e, para os Produtores Independentes de Energia Elétrica, é dada pela formulação a seguir:

$$
\text { TFSEE }=0,4 \% * B E T U * P
$$

Sendo:

$B E T U$ : Benefício Econômico Típico Unitário $(\mathrm{R} \$ / \mathrm{kW})$

$P$ : Potência nominal instalada em operação comercial até o dia 31 de dezembro do ano anterior $(\mathrm{kW})$.

O Benefício Típico Unitário é dado por:

$$
B E T U=8,76 * F C g * P m g
$$

FCg: Fator médio de capacidade da atividade de geração

Pmg: Preço médio de compra de energia no ACR em R \$MWh

O fator médio utilizado para o cálculo é 0,5 , enquanto o $P m g$ será definido pela média dos preços dos contratos no ambiente regulado, sendo este valor publicado anualmente pela agência reguladora junto com o cálculo da TFSEE. Como consequência, o valor de $B E T U$ é igual para todos os geradores.

\footnotetext{
${ }^{44}$ Percentuais definidos pela Lei no 13.661 de 8 de maio de 2018, a qual alterou a Lei no 8.001 de 13 de março de 1990 .
} 


\section{Uso do Bem Público}

O UBP é um encargo estabelecido para outorgas de concessão ou autorização de energia elétrica que sejam prorrogadas, sendo posteriormente revertido à modicidade tarifária, conforme definido na Lei $\mathrm{n}^{\circ} 12.783$, de 2013. Inclusive, sua metodologia de cálculo foi objeto de discussão da Audiência Pública $n^{\circ}$ 9, realizada em 2018, pela ANEEL.

\section{$\underline{\text { ONS }}$}

Dado o caráter público dos serviços prestados pelo ONS ao setor elétrico, sua remuneração está atrelada a uma tarifa. A Resolução n²81 de $1^{\circ}$ de outubro de 1999 definiu que o orçamento do ONS deveria estar incluído no Encargo de Serviços de Transmissão (EUST). Posteriormente, em 2015, a Resolução Normativa $n^{\circ} 666$, definiu que $97 \%$ do orçamento do ONS é remunerado pela parcela adicionada à Receita Anual Permitida (RAP), sendo os demais $3 \%$ cobrados nas contribuições associativas de seus associados. 


\section{TEORIA DAS OPÇÕES REAIS}

\subsection{Considerações Gerais}

Uma alternativa comumente utilizada para avaliações de investimentos, que supera algumas das limitações da metodologia de FCD tradicional, é a TOR, posto que permite a incorporação de incertezas dentro da metodologia tradicional (PLESS, ARENT, et al., 2016).

A intuição por trás da utilização da TOR é que a existência da possibilidade do exercício de uma opção permite capturar ganhos quando os riscos são positivos, assim como a mitigação de perdas quando os riscos são negativos, o que melhora a percepção de valor dos projetos.

Características particulares de investimentos no setor elétrico, como a irreversibilidade e a sua subjugação às incertezas de preço e quantidade, fazem com que a TOR seja comumente considerada como melhor escolha para sua avaliação em detrimento de outras metodologias. O trabalho (SANTOS, SOARES, et al., 2014), por exemplo, discute extensamente as vantagens da TOR em comparação com metodologias tradicionais para a avaliação de investimentos em pequenas hidrelétricas.

Por estas razões, a TOR foi escolhida para a análise de investimentos no contexto desta pesquisa. Nas próximas seções são os conceitos principais, as metodologias mais utilizadas, além da apresentação de uma revisão bibliográfica histórica sobre o tema.

\subsection{Conceito dos Contratos de Opções Financeiras}

Conforme definido em (BRASIL, FREITAS, et al., 2007), uma opção representa ser detentor do direito de comprar ou vender determinado ativo-objeto em certa data (ou até certa data), por um preço determinado. $O$ agente que lançou esta opção tem a obrigação de vender ou comprar este ativo, caso o primeiro exerça seu direito. O lançador recebe um prêmio, correspondente ao valor em dinheiro para remunerar o risco assumido. A diferença básica entre um contrato futuro e uma opção é que, na opção, o comprador tem o direito, mas não a obrigação de vender ou comprar o ativo-objeto. No caso do contrato futuro, a obrigação existe.

São definidos então dois tipos de contrato, a opção de compra (call) e a opção de venda (put), podendo ser do tipo europeu ou americano. A opção europeia pode ser 
exercida somente na data específica de seu vencimento, enquanto a opção americana pode ser exercida até a data de seu vencimento. A possibilidade de exercício antecipado, faz com que a opção americana tenha mais valor que a opção europeia. O preço préestabelecido para uma opção é chamado de strike-price, enquanto a data de exercício se denomina tanto de exercise date, quanto de maturity.

Segundo (BRASIL, FREITAS, et al., 2007), o preço de um contrato de opção é definido com base em seis propriedades:

- Valor da Ação

- Preço de Exercício

- Tempo até o Vencimento

- Volatilidade do Preço da Ação

- Taxa de Juros Livre de Risco

- Dividendos Esperados até a Data de Vencimento da Opção

Ademais, a influência destes fatores nos preços dos contratos de opções vai depender do tipo de posição assumida pelo investidor, ou seja, se está comprado (long) ou vendido (short). As Figura 34 e Figura 35 ilustram as posições na call e na put.
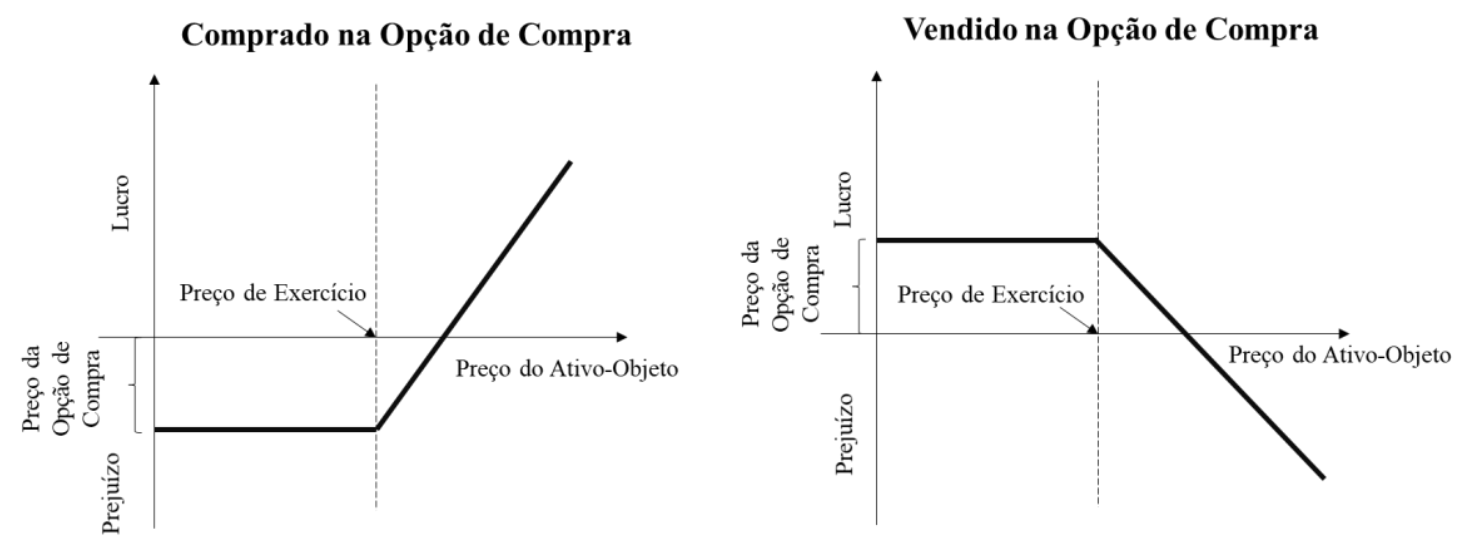

Figura 34: Ilustrações das Posições Long e Short na Call

Fonte: Autora 
Comprado na Opção de Venda

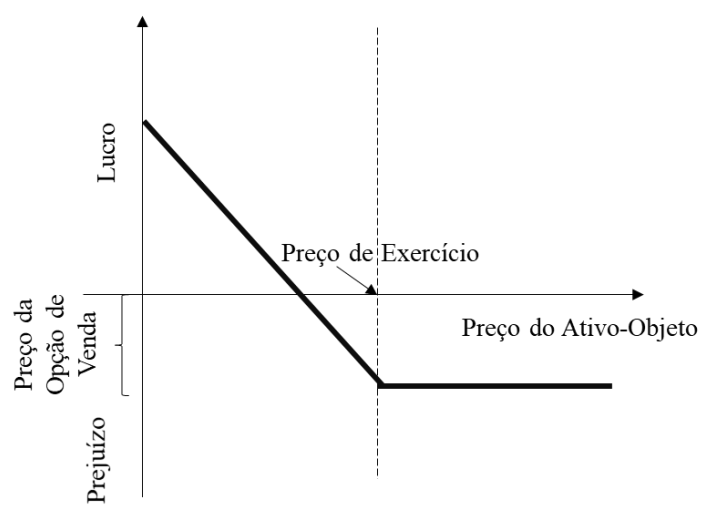

\section{Vendido na Opção de Venda}

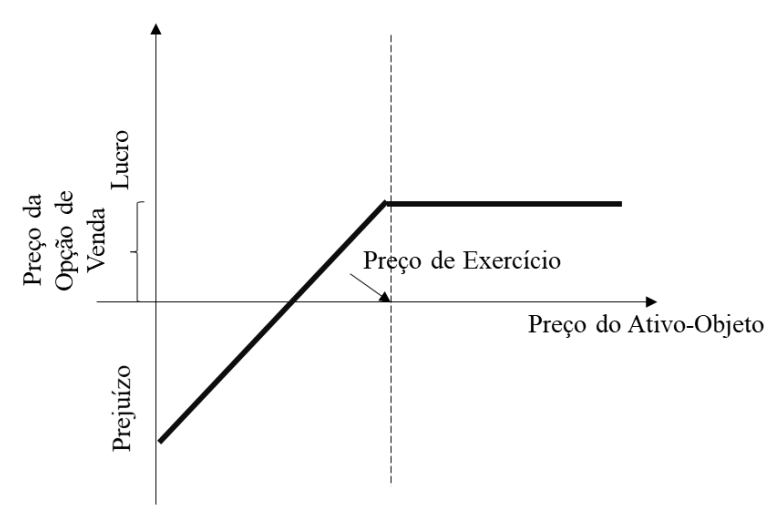

Figura 35: Ilustrações das Posições Long e Short na Put

Fonte: Autora

Cita-se aqui um exemplo numérico de venda de uma call com base na referência (CFI, 2020). Assume-se que um investidor comprou uma opção de compra da ação ABC com o preço de exercício de $\$ 25$, pagando $\$ 150$ pela opção, sendo que uma opção da ação equivale a 100 ações da empresa $\mathrm{ABC}$. Na data de expiração da opção, as ações da empresa ABC estão sendo vendidas a \$35 por ação. Nesse caso, o comprador da opção exerce o direito de comprar 100 ações da empresa ABC a \$25, pagando \$2.500 e vendendo logo em seguida ao preço de mercado de $\$ 35$, arrecadando $\$ 3.500$. Portanto, seu lucro na operação é a diferença de \$1.000 entre a compra e a venda, subtraída do prêmio de $\$ 150$, que era o custo da opção de compra, portanto, obtendo um total de $\$ 950$.

Serão abordados aqui dois modelos para precificar opções, o modelo binomial e o modelo de Black and Scholes.

O modelo binomial assume que o preço do ativo $S$ pode aumentar para $S u$, com probabilidade $p$, ou cair para $S d$, com probabilidade $(1-p)$, em qualquer período, conforme ilustra a figura abaixo:

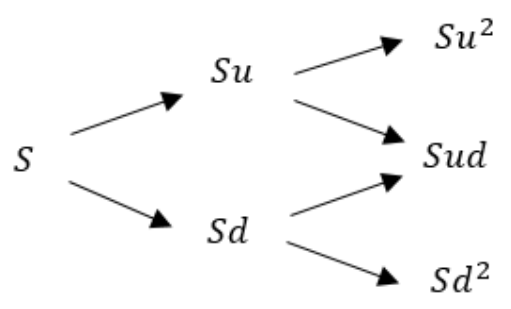

Figura 36: Modelo Binomial

Fonte:Autora 
Temos a seguinte formulação para o cálculo dos parâmetros $u, d$ e $p$, conforme foram definidos matematicamente por (COX, ROSS e RUBINSTEIN, 1979):

$$
\begin{aligned}
& u=e^{\sigma \sqrt{\Delta t}} \\
& d=e^{-\sigma \sqrt{\Delta t}} \\
& p=\frac{e^{r \Delta t}-d}{u-d}
\end{aligned}
$$

Sendo:

$u$ : Taxa contínua de crescimento do preço do ativo-objeto

$p$ : Probabilidade de crescimento

$d$ : Taxa contínua de redução do preço do ativo-objeto

$r$ : Taxa de juros por estágio

$\sigma$ : Desvio padrão anual da taxa contínua de retorno do ativo objeto

$\Delta t$ : O inverso do número de estágios por ano.

O modelo binomial em tela é representado por um processo estocástico multiplicativo. No limite, quando o número de estágios atinge valores maiores, a distribuição de probabilidades dos resultados é representada por uma distribuição lognormal. Sendo o ativo-objeto uma ação, a distribuição de probabilidades proposta se afigura razoável, uma vez que ações não assumem valores negativos. Contudo, se o ativoobjeto puder assumir valores negativos, é razoável a adoção de um processo estocástico aditivo, que no limite apresentará os resultados com a distribuição de probabilidades semelhante à distribuição normal.

$\mathrm{O}$ valor de um ativo qualquer no mercado pode ser estabelecido associando-se ao preço de negociação. Não obstante, para sua valoração é usual utilizar a teoria de portfólios replicantes, construindo-se assim um portfólio de ativos, que combine ativos de risco com ativos livre de risco. A ideia é que este portfólio crie os mesmos fluxos de caixa que a opção que está sendo avaliada.

Sendo assim, o portfólio replicante de uma call, com strike price $K$, vai envolver o empréstimo de $B$ reais, a uma taxa livre de risco, e a aquisição de $\Delta$ ativos do portfólio replicante. Onde: 


$$
\Delta=\frac{(C u-C d)}{S u-S d}
$$

Sendo:

Cu: Valor da call quando o preço do ativo objeto é maior (Su)

$C d$ : Valor da call quando o preço do ativo objeto é menor $(S d)$

Quando avaliamos uma situação com multi-períodos, o valuation deve ser iterativo, vindo do último período até o ponto inicial. Nesses termos, o valor da opção ao final do processo de precificação pelo modelo binomial é dado pela fórmula (20):

$$
\text { Valor da Call }=\Delta * \text { Valor Atual do Ativo Objeto }+B
$$

O modelo Black-Scholes, assim como a teoria moderna de opções financeiras, tem seus fundamentos nos trabalhos de Fischer Black e Myron Scholes, sendo (BLACK e SCHOLES, 1973) o trabalho que apresentou pela primeira vez uma formulação completa para o preço de equilíbrio de uma opção de compra, baseado numa carteira livre de risco, utilizando o conceito de não-arbitragem no mercado para se encontrar o preço de uma opção sobre uma ação. O resultado independe do nível de aversão ao risco do investidor, carregando assim o conceito de neutralidade ao risco. Este trabalho resultou posteriormente num Prêmio Nobel de Economia para Myron Scholes e Robert Merton.

Black-Scholes é uma simplificação do modelo binomial, que torna infinitesimal o período de variação do preço do ativo. Portanto, deve-se lembrar as sete considerações feitas por Black and Scholes, e listadas em (COPELAND e ANTIKAROV, 2003), para que se possa entender suas limitações quando utilizado para avalição de opções reais. $O$ modelo Black-Scholes considera:

1. O exercício da opção só pode ser realizado na data de exercício, pois se trata de uma opção europeia.

2. Só existe uma fonte de incerteza, portanto opções baseadas em mais de um ativo, chamadas “rainbow options”, não podem ser analisadas desta forma.

3. A opção é dependente de um único ativo objeto de risco, portanto opções de opções, chamadas de "compound options", não podem ser analisadas desta forma.

4. O ativo objeto não paga dividendos. 
5. O valor atual de mercado e o processo estocástico seguido pelo ativo objeto são conhecidos.

6. A variância do retorno do ativo objeto é constante no tempo.

7. O preço de exercício é conhecido e constante.

Já são conhecidas e utilizadas alterações da formulação original do modelo BlackScholes que permitem corrigir algumas das limitações apresentadas acima, como por exemplo, a possibilidade de exercício antecipado, o pagamento de dividendos e o impacto do exercício de uma opção no valor do ativo objeto. Essas derivações da formulação original podem ser encontradas em (DAMODARAN). A formulação original do modelo Black-Scholes, para uma call, é dada por:

$$
\begin{gathered}
C_{0}=S_{0} N\left(d_{1}\right)-K e^{\left(-r_{f} T\right)} N\left(d_{2}\right) \\
d_{1}=\frac{\ln \left(\frac{S}{K}\right)+r_{f} T}{\sigma \sqrt{T}}+\frac{1}{2} \sigma \sqrt{T} \\
d_{2}=d_{1}-\sigma \sqrt{T}
\end{gathered}
$$

Sendo:

$S_{0}$ : O preço do ativo objeto

$N\left(d_{1}\right)$ : Probabilidade de uma variável aleatória, de distribuição normal padronizada, ser menor ou igual à $d_{1}$

$K$ : Preço de exercício da opção

$r_{f}$ : Taxa livre de risco

$T$ : Tempo até o vencimento

$e$ : Algarismo neperiano

$N\left(d_{2}\right)$ : Probabilidade de uma variável aleatória, de distribuição normal padronizada, ser menor ou igual à $d_{2}$

$\sigma$ : Desvio padrão anual da taxa contínua de retorno do ativo-objeto

Vale destacar que nas formulações apresentadas acima $d_{1}$ representa a probabilidade de $S_{0}$ ser o preço justo. Já $d_{2}$ representa a probabilidade de o preço do ativo ser maior que o preço de exercício $K$ na data de exercício. 
Segundo (DAMODARAN), quando o tempo se torna infinitesimal, a distribuição assintótica pode assumir dois resultados. Se, quando t se aproxima de 0 , a variação de preço se torna menor, a distribuição assintótica se torna uma distribuição normal e o preço é contínuo. Contudo, se quando t se aproxima de 0 , a variação de preço continua grande, a distribuição assintótica se torna uma distribuição de Poisson e, sendo assim, permite variações abruptas de preço. O modelo de Black-Scholes é aplicado quando a distribuição é normal, assumindo que o preço é contínuo, e que, portanto, não há variações abruptas nos preços do ativo.

O princípio do portfólio replicante também é utilizado no modelo Black-Scholes, sendo o valor da call representado pela soma da compra de $N\left(d_{1}\right)$ partes e o empréstimo no valor de $K e^{-r_{f} T} N\left(d_{2}\right)$.

Apesar de não estar contemplado na formulação original, a análise de ativos que pagam dividendos pode ser realizada utilizando o modelo de Black-Scholes através de adaptação. Conceitualmente, o pagamento de dividendos diminui o valor de uma call e aumenta o valor de uma put. Ao se considerar o retorno dos dividendos $y$, que é o racional entre valor dos dividendos pelo valor do ativo, constante no tempo, pode-se adotar o modelo Black-Scholes da seguinte forma:

$$
\begin{gathered}
C_{0}=S_{0} e^{(-y t)} N\left(d_{1}\right)-K e^{\left(-r_{f} T\right)} N\left(d_{2}\right) \\
d_{1}=\frac{\ln \left(\frac{S}{K}\right)+\left(r_{f}-y+\frac{\sigma^{2}}{2}\right) T}{\sigma \sqrt{T}} \\
d_{2}=d_{1}-\sigma \sqrt{T}
\end{gathered}
$$

Apesar de se ter estabelecido formulações exclusivas para calls, o valor de uma put, $P_{0}$, pode ser facilmente derivado do valor de uma call, $C_{0}$, com mesmo tempo e preço de exercício, o que é chamado de put-call parity. A relação é dada pela fórmula abaixo:

$$
C_{0}-P_{0}=S-K e^{-r_{f} * t}
$$




\subsection{Aplicando o Conceito de Precificação de Opções Financeiras em Opções Reais}

A avaliação de projetos utilizando a TOR agrega o valor de flexibilidades gerenciais na avaliação tradicional de fluxo caixa descontado, conforme a fórmula a seguir:

$$
V P L_{F}=V P L_{T}+V O R
$$

Sendo:

$$
\begin{aligned}
& V P L_{F}: \text { Valor presente líquido final } \\
& V P L_{T}: \text { Valor presente líquido tradicional } \\
& V O R: \text { Valor presente líquido final }
\end{aligned}
$$

Observa-se que a TOR não rejeita a metodologia tradicional de avaliação de projetos, apenas a complementa. Segundo (BRASIL, FREITAS, et al., 2007), a TOR permite avaliar opções tais como expandir atividades, abandonar investimentos, investir para aprender e entrar em novo setor, adiar um projeto, trocar ou flexibilizar um processo de produção, combinar diversas flexibilidades e contrair a utilização de capacidades.

(MENDES, 2012) expõe a classificação dos diferentes tipos opções reais feita por (DIAS, 2011):

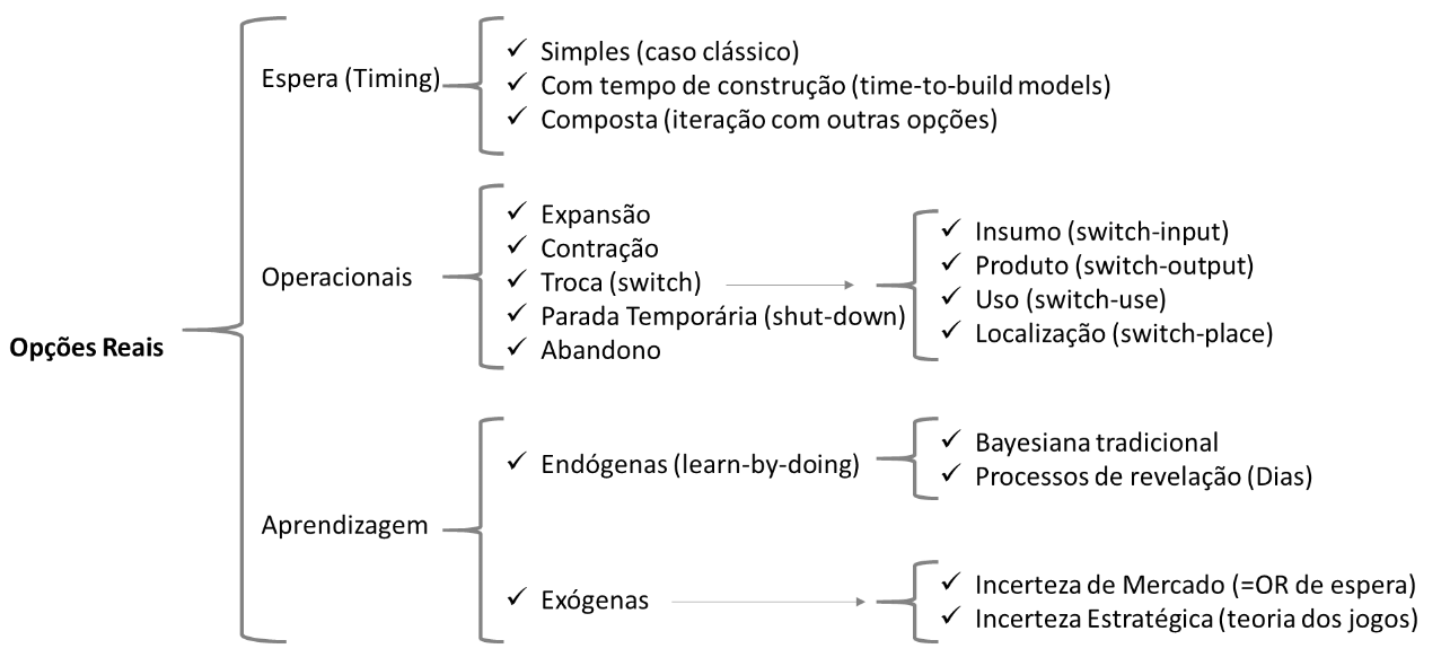

Figura 37: Tipos de Opções Reais

Fonte: Autora 
Por exemplo, quando o valor de um projeto varia de forma importante no tempo, a opção de adiá-lo para um momento mais oportuno pode ser interessante, conferindo-lhe assim, a característica de uma call. Nesse caso, o ativo-objeto é o projeto, o preço de exercício é o investimento necessário para a realização do projeto e o tempo até o vencimento da opção é o período em que a empresa pode tomar a decisão de realizar este investimento. Ademais, o valor presente dos fluxos de caixa esperados e sua variância representam o valor e variância do ativo-objeto.

O adiamento do projeto, a cada ano, leva a um ano a menos de fluxo de caixa. Esse efeito é representado na formulação de Black-Scholes pelo retorno dos dividendos, que é dado nesse caso pelo inverso tempo em que existe a opção de adiar o projeto.

É possível comparar de forma simples as variáveis de uma opção financeira contra as variáveis de uma opção real, obtendo-se a relação apresentada na Tabela a seguir.

Tabela 10: Variáveis da TOR vs. Variáveis de uma Call.

\begin{tabular}{|c|c|c|}
\hline Projeto & Variável & Call \\
\hline Valor presente dos fluxos de caixa do \\
$\begin{array}{c}\text { projeto } \\
\text { Investimento }\end{array}$ & $S_{0}$ & Preço do ativo-objeto hoje. \\
\hline Tempo no qual a decisão de investir pode & $X$ & Preço de exercício \\
\hline ser tomada & $T$ & Tempo até o vencimento \\
\hline Variabilidade do valor do projeto & $\sigma$ & Volatilidade do preço da ação \\
\hline Valor do dinheiro no tempo & $r$ & Taxa de juros livre de risco \\
\hline
\end{tabular}

Fonte: (MENDES, 2012)

(MENDES, 2012) aponta que para o assunto 'investimento sob incerteza', existem três pilares básicos: (i) irreversibilidade; (ii) timing e (iii) incerteza. A irreversibilidade pode ser do tipo total, que ocorre quando sob nenhuma hipótese o investimento realizado pode ser recuperado, ou parcial, que ocorre quando ao menos parte do dinheiro aportado pode ser recuperado se houver a decisão de que o investimento não deve ser continuado. Usualmente, a maior parte de um investimento realizado se transforma em custo afundado (ou na nomenclatura em inglês sunk cost).

A escolha do melhor timing para a realização de um projeto é uma decisão difícil de tomar, sendo uma opção valiosa a flexibilidade que a TOR proporciona, uma vez que permite a quantificação dessa escolha. Essa flexibilidade não vai existir apenas quando o investimento for do tipo 'agora ou nunca'. 
Com relação às incertezas, (MENDES, 2012) aponta os seguintes tipos: (i) incerteza econômica ou de mercado; (ii) incerteza técnica; (iii) incerteza estratégica. As incertezas do tipo econômica ou de mercado não podem ser completamente mitigadas pelas empresas, são exógenas ao processo decisório, pois emanam de movimentos aleatórios que podem surgir de a qualquer momento como guerras, fim de acordos comerciais, crises políticas, crises econômicas, etc, que podem vir a afetar o desempenho daquele negócio.

Já as incertezas técnicas podem vir a ser mitigadas por ações e decisões gerenciais, portanto sendo endógena ao processo decisório. Nesse sentido, a realização de investimentos em escalas menores para um melhor entendimento dos riscos ajuda a diminuir a incerteza com relação ao investimento. Já as incertezas de natureza estratégica têm sua origem no comportamento daqueles que interagem com o investimento e podem ser modeladas por Teoria dos Jogos.

Deve-se atentar que as incertezas do projeto estão refletidas na variação dos fluxos de caixa esperados e não no valor do investimento inicial, que é considerado constante ao longo do período em análise. Quando existem incertezas quanto ao valor do investimento inicial, de forma alternativa, pode-se calcular o valor da call como um percentual do investimento inicial. Basta assumir o investimento inicial $(K)$ sendo unitário e o preço do ativo objeto $(S)$ como o racional do valor presente dos fluxos de caixa pelo valor inicial do investimento, uma vez que a variância do numerador e denominador sejam iguais.

Justamente por estar lidando com incertezas, estimar a variância dos fluxos de caixa esperados pode não ser uma tarefa fácil. Em (DAMODARAN), são listadas três possíveis formas de estimá-la. A primeira forma consiste em analisar a variância dos fluxos de caixa de projetos similares, que já foram realizados no passado. A segunda forma consiste em atribuir probabilidades a diferentes cenários de mercado, posteriormente, gerar fluxos de caixa para cada cenário, sendo a variância estimada a partir do valor presente destes cenários. Alternativamente a esta opção, pode-se ainda estimar distribuições de probabilidade para diferentes inputs que abrigam incerteza, para, a partir de simulações, se obter a variância dos valores presentes resultantes. Por fim, a terceira forma citada consiste em estimar a variância de um projeto a partir da variância do valor de empresas que atuam no mesmo setor. 
Comumente, quando analisando um projeto, serão diversas as fontes de incertezas que se deseja levar em consideração. Conforme proposto por (COPELAND e ANTIKAROV, 2003), para evitar a complexidade de lidar com as incertezas em separado, duas hipóteses são adotadas:

1. O pressuposto do MAD (Marketed Asset Disclaimer) que utiliza o valor presente do ativo-objeto sem flexibilidade como se este fosse securitizado pelo mercado.

2. Preços (ou fluxos de caixa) propriamente antecipados flutuam randomicamente.

Mesmo a mais complexa combinação de incertezas poderá ser reduzida à uma única incerteza. A demonstração foi realizada em (SAMUELSON, 1965), acarreta que, não importa o comportamento assumido pelo fluxo de caixa, o valor do projeto seguirá uma caminhada aleatória com distribuição normal e volatilidade constante.

Conforme elucidado em (COPELAND e ANTIKAROV, 2003), a demonstração de Samuelson implica que a maioria das análises com TOR podem ser divididas em quatro etapas, conforme ilustrado na Figura a seguir.

\begin{tabular}{|c|c|c|c|c|}
\hline & Passo 1 & Passo 2 & Passo 3 & Passo 4 \\
\hline & $\begin{array}{c}\text { Computar o caso } \\
\text { base do valor } \\
\text { presente usando } \\
\text { um modelo de FCD }\end{array}$ & $\begin{array}{c}\text { Modelar a incerteza } \\
\text { usando árvore de } \\
\text { eventos. }\end{array}$ & $\begin{array}{c}\text { Identificar e } \\
\text { incorporar as } \\
\text { flexibilidades } \\
\text { criando uma árvore } \\
\text { de decisão. }\end{array}$ & $\begin{array}{l}\text { Realizar a análise } \\
\text { com Opções Reais }\end{array}$ \\
\hline Objetivos & $\begin{array}{l}\text { Computar o caso base } \\
\text { de valor presente sem } \\
\text { flexibilidade em } t=0 \text {. }\end{array}$ & $\begin{array}{l}\text { Entender como o valor } \\
\text { presente evolui no } \\
\text { tempo. }\end{array}$ & $\begin{array}{l}\text { Analisar a árvore de } \\
\text { eventos para identificar } \\
\text { e incorporar as } \\
\text { flexibilidades } \\
\text { respondendo as novas } \\
\text { informações. }\end{array}$ & $\begin{array}{l}\text { Valor o projeto usando } \\
\text { uma metodologia } \\
\text { algébrica simples } \\
\text { através de planilha } \\
\text { Excel. }\end{array}$ \\
\hline Comentários & $\begin{array}{l}\text { Valor presente } \\
\text { tradicional sem } \\
\text { flexibilidade. }\end{array}$ & $\begin{array}{l}\text { Ainda sem flexibilidade, } \\
\text { o valor aqui deve ser } \\
\text { igual ao valor do Passo } \\
1 . \text { Estimar a incerteza } \\
\text { usando ou dados } \\
\text { históricos ou } \\
\text { estimativas gerenciais } \\
\text { como entrada. }\end{array}$ & $\begin{array}{l}\text { A flexibilidade é } \\
\text { incorporada na árvore } \\
\text { de eventos, que é } \\
\text { transformada em uma } \\
\text { árvore de decisão. A } \\
\text { flexibilidade altera as } \\
\text { características de risco } \\
\text { do projeto, portanto, o } \\
\text { custo de capital mudou. }\end{array}$ & $\begin{array}{l}\text { A análise com opções } \\
\text { reais vai incluir o valor } \\
\text { presente do caso base } \\
\text { sem flexibilidade, mais } \\
\text { o valo da opção } \\
\text { (flexibilidade). Quando } \\
\text { houver muita incerteza } \\
\text { e flexibilidade ou valor } \\
\text { da opção é substancial. }\end{array}$ \\
\hline
\end{tabular}

Figura 38: Método Geral: Processo de 4 passos.

Fonte:Autora, (COPELAND e ANTIKAROV, 2003)

Nesse caso, a primeira das etapas do processo se caracteriza pela determinação do VPL pela metodologia tradicional sem considerar flexibilidades. 
A segunda etapa implica no uso de Simulação de Monte Carlo - SMC para considerar as incertezas dentro de uma planilha de valuation e estimar a volatilidade do resultado. A relação das incertezas com o tempo e a correlação entre estas pode ser bem capturada pela SMC e, como resultado da segunda etapa, obtém-se uma árvore de eventos que modela o processo estocástico do valor do ativo-objeto como uma caminhada aleatória, ressaltando-se que o uso das incertezas em separado poder ser necessário em alguns casos. Nesses casos, são usadas opções do tipo arco-íris (rainbow options).

A terceira etapa consiste em atribuir decisões à árvore de eventos, ou seja, cada nó capturará a flexibilidade de decisão em cada ponto. E, por fim, a quarta etapa implica na valoração da árvore de decisão, num processo retroativo no tempo, de nó em nó, usando ou o método dos portfólios replicantes ou método de probabilidades neutra ao risco.

Quando se deseja aplicar os modelos de precificação de opções financeiras para precificação de opções reais, quatro importantes características das opções reais devem ser levadas em consideração:

1. O ativo em análise não pode ser comercializado como uma ação, dificultado a utilização dos portfólios replicantes e arbitragem.

2. O preço do ativo não é necessariamente contínuo, conforme assumido no modelo Black-Scholes. Se esta consideração é violada, o modelo pode subestimar o valor de opções que estejam fora do preço de mercado.

3. A variância não é necessariamente conhecida e contínua ao longo do tempo.

4. O exercício da opção não é instantâneo, como no caso das ações.

(COPELAND e ANTIKAROV, 2003) pontuam também os erros mais comuns na implementação de opções reais:

1. Assumir que a volatilidade do ativo-objeto é a mesma que o de alguma de suas componentes.

2. Complicar em excesso a análise ao incluir muitas incertezas ou muitas opções.

3. A utilização do modelo de Black-Scholes como uma aproximação do modelo geral. Deve-se lembrar que o método de Black-Scholes é mais simples e restritivo que os demais.

4. Resolver a árvore de decisão sem utilizar ou a teoria do portfólio sem risco ou medida neutra ao risco, o que não garantiria a não arbitragem. 


\subsection{Precificação de Opções Reais}

(MENDES, 2012) expõe a classificação dos diferentes métodos disponíveis para precificação de opções reais feita por (DIAS, 2011):

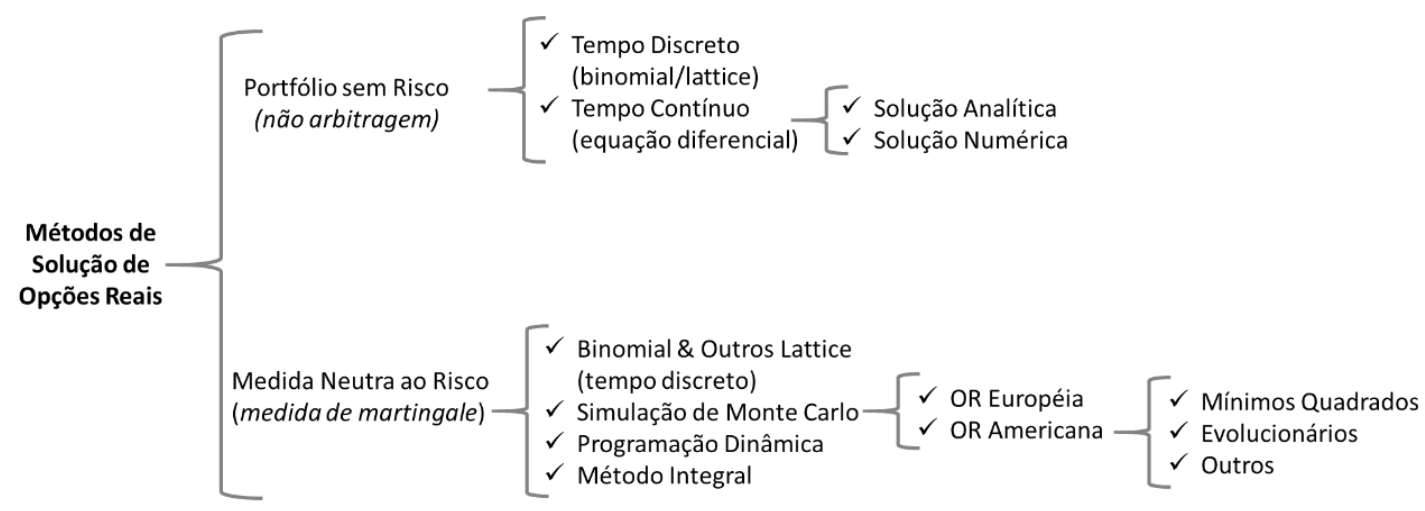

Figura 39: Diferentes Métodos de Precificação de Opções Reais

Fonte: Autora

O pressuposto da não arbitragem vem da teoria de livre preferência desenvolvida em (MODIGLIANI e MILLER, 1958). Conforme (DIAS, 2014), é a possibilidade de se ter lucro no mercado, sem se ter risco de perder dinheiro em qualquer cenário e sem ter de fazer investimento líquido (sem ter dinheiro).

(MENDES, 2012) aponta que os modelos de precificação de opções reais tendem a ser livres de arbitragem, ou seja, constrói-se um portfólio sem risco, composto pelos ativos básicos, os quais tem como retorno a taxa livre de risco.

O método do portfólio sem risco, conforme explica (MENDES, 2012), pressupõe uma carteira $\Phi$ que seja composta pela opção $F$ menos $n$ ('delta hedge') vezes o ativo $V$. Para que não haja a possibilidade de arbitragem, o valor de $n$ é tal qual a taxa de desconto da carteira seja a taxa livre de risco.

$$
\Phi=F-n V
$$

$\mathrm{O}$ 'delta hedge' $n$ deve ser visto como a derivada opção $F$ em relação ao ativo $V$. No caso em que o tempo é uma variável discreta, tem-se que:

$$
n=\frac{F^{+}-F^{-}}{V^{+}-V^{-}}
$$


No caso do tempo discreto, devemos lembrar que $F$ é função de $V(V: F(V))$ e o que se deseja calcular é o valor da opção no momento inicial $F(t=0)$, quando sabe-se apenas o valor da ação no momento inicial $V(t=0)$, os valores esperados $\left(V^{+} e V^{-}\right)$com que seu valor vai variar e a probabilidade $p$. Deve-se atentar que a taxa de desconto da opção não é conhecida e é diferente da taxa de desconto da ação $\mu$.

Portanto, para que se obtenha o portfólio livre de risco $n$ é escolhido, tal que, os valores dos portfólios nos dois cenários $\Phi^{+}$e $\Phi^{-}$são iguais. Pois, nesse caso, tem-se realmente o portfólio sem risco.

$$
\begin{aligned}
& \Phi^{+}=\Phi^{-}=\Phi(t=1) \\
& \Phi(t=0)=\frac{\Phi(t=1)}{1+r}
\end{aligned}
$$

Onde $r$ é a taxa livre de risco. Sendo ${ }^{45}$ :

$$
\Phi(t=1)=\frac{u F^{+}-d F^{-}}{u-d}
$$

Onde:

$$
u=\frac{V^{+}}{V} \text { ed } d=\frac{V^{-}}{V}
$$

Então chega-se num resultado em que $F(t=0)$ depende apenas de:

$$
F(t=0)=\frac{u F^{-}-d F^{+}}{(u-d)(1+r)}+\frac{F^{+}-F^{-}}{u-d}
$$

Nota-se que ao utilizar a (35), pode-se calcular o valor do derivativo sem que seja necessário conhecer sua própria taxa de desconto, pois utilizou-se o conceito da nãoarbitragem.

Já no caso em que o tempo é contínuo demonstração semelhante pode ser realizada através da utilização de derivadas parciais. No caso de tempo contínuo o método do portfólio sem risco é do tipo 'contingent claims approach', amplamente discutido em (DIXIT e PINDYCK, 1994).

$$
n=\frac{\partial F}{\partial V}
$$

\footnotetext{
${ }^{45}$ A demonstração da Equação (33) pode ser encontrada nas páginas 174 - 176 de (DIAS, 2014).
} 
A segunda metodologia para o cálculo do valor presente do derivativo vem da medida neutra ao risco ou Medida Equivalente de Martingale. Conforme (DIAS, 2014), o retorno total de $V$ sob a medida de probabilidade real $P$ (aqui $p$ e $1-p$ ) é $\mu$, mas pode-se mudar a medida de probabilidade de forma que ao invés de $\mu$ o retorno total seja igual à taxa livre de risco $r$.

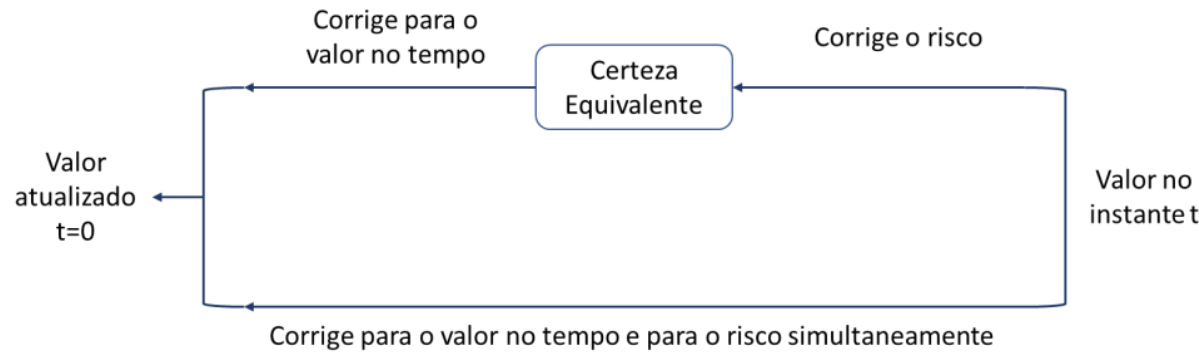

Figura 40: Maneiras de calcular o valor presente

Fonte: Autora, (DIAS, 2014)

Portanto, ao mudar a medida de probabilidade real de $P$ para a artificial $Q$, adota-se novas probabilidades $(q$ e $1-q)$ com as quais os cenários de $V$ vão evoluir, podendo-se então descontá-lo no tempo à taxa $r$ ao invés de $\mu$. É demonstrado ${ }^{46}$ que a nova probabilidade $q$ é válida tanto para $V$, quanto para $F$. Tem-se que:

$$
q=\frac{1+r-d}{u-d}
$$

E para o cálculo do valor presente do derivativo tem-se que:

$$
F(t=0)=\frac{E^{Q}[F(t=1)]}{(1+r)}=\frac{q F^{+}+(1-q) F^{-}}{(1+r)}
$$

A modalidade neutra ao risco também é aplicável ao tempo contínuo através da utilização do Teorema de Girsanov, conforme demonstra (DIAS, 2014).

\subsection{Modelo Binomial}

Dentre as metodologias para precificação de opções reais, o modelo binomial (em inglês binomial lattice) é uma das mais utilizadas devido ao seu caráter simples intuitivo. O modelo binomial foi introduzido em (COX, ROSS e RUBINSTEIN, 1979), onde os autores se valeram da teoria da probabilidade para desenvolvê-lo.

${ }^{46}$ A demonstração pode ser encontrada nas páginas 183 - 184 de (DIAS, 2014) 
Conforme (COPELAND e ANTIKAROV, 2003), a metodologia utiliza a matemática discreta para atingir os resultados isomórficos ao Lema de Itô ${ }^{47}$ usado por (BLACK e SCHOLES, 1973) e outros. Um melhor entendimento do funcionamento do modelo binomial pode vir através do estudo do Triângulo de Pascal, conforme expõe (COPELAND e ANTIKAROV, 2003).

A seguir será exposta a demonstração apresentada em (COPELAND e ANTIKAROV, 2003). A forma geral de uma função payoff em um processo multiplicativo é dada por:

$$
\text { Máximo }\left[0, u^{n} d^{T-n} V_{0}-X\right]
$$

Onde:

$u$ : Movimento de subida;

$d$ : Movimento de descida;

$n$ : Número de movimentos de subida/descida envolvidos na precificação;

$T$ : Número total de períodos;

$V_{0}$ : Valor inicial do ativo-objeto;

$X$ : Valor do investimento.

Ao utilizar a expressão de probabilidades binomiais, a probabilidade de cada payoff, dada uma probabilidade $p$, é dada por:

$$
B(n \mid T, p)=\frac{T !}{(T-n) ! n !} p^{n}(1-n)^{T-n}
$$

Multiplicando o payoff pelas probabilidades e somando todas as possibilidades de payoffs temos:

$$
C_{0}=\left\{\sum_{n=0}^{T} \frac{T !}{(T-n) ! n !} p^{n}(1-n)^{T-n} \operatorname{Máximo}\left[0, u^{n} d^{T-n} V_{0}-X\right]\right\} \div\left(1+r_{f}\right)^{T}
$$

Destaca-se, contudo que alguns payoffs serão zero, porque a opção acabar por estar 'out-of-the-money' ${ }^{48}$ em muitos dos seus estados. Portanto assume-se que $a$ é o número positivos de estados da opção. Nesse caso, reescreve-se a expressão da seguinte maneira:

\footnotetext{
${ }^{47} \mathrm{O}$ 'Lema de Itô' ou o 'Processo de Itô' é também conhecido como o Teorema Fundamental do Cálculo Estocástico, isso porque, a modelagem de processos estocásticos é dependente utilização do cálculo diferencial.

${ }^{48}$ Essa situação ocorre quando o exercício da opção é inútil ao seu detentor. No caso, de uma call, esta está out-of-the-money quando seu preço de exercício for maior que o preço de ativo no mercado. No caso de uma put, esta está out-of-the-money quando seu preço de exercício for inferior que preço do ativo no mercado.
} 


$$
C_{0}=\left\{\sum_{n=a}^{T} \frac{T !}{(T-n) ! n !} p^{n}(1-n)^{T-n}\left[u^{n} d^{T-n} V_{0}-X\right]\right\} \div\left(1+r_{f}\right)^{T}
$$

Observa-se a equação pode ser subdividida em duas partes distintas:

$$
\begin{aligned}
C_{0}=V_{0}\left[\sum_{n=a}^{T} \frac{T !}{(T-n) ! n !} p^{n}(1-n)^{T-n} \frac{u^{n} d^{T-n}}{\left(1+r_{f}\right)^{T}}\right] \\
\\
\quad-X\left(1+r_{f}\right)^{-T}\left[\sum_{n=a}^{T} \frac{T !}{(T-n) ! n !} p^{n}(1-n)^{T-n}\right]
\end{aligned}
$$

Conforme (COPELAND e ANTIKAROV, 2003), o segundo termo da equação representa o preço de exercício da opção descontado no tempo, multiplicado pela distribuição binomial complementar $B(n \geq a \mid T, p)$, que é a probabilidade acumulada de ter a opção 'in-the-money' (quando o exercício da opção é positivo), onde as probabilidades são as probabilidades de equivalente de certeza ${ }^{49}$ determinadas pelo portfólio de hedge livre de risco. Temos que $p$ é dado por:

$$
p \equiv \frac{\left(1+r_{f}\right)-d}{u-d}
$$

Ainda conforme (COPELAND e ANTIKAROV, 2003), o primeiro termo da fórmula (43), é o valor atual do ativo-objeto $V_{0}$, multiplicado por outra distribuição de probabilidade complementar que é igual ao inverso do coeficiente de hedge do ativoobjeto necessário para formar um portfólio sem risco, formado por uma unidade do ativoobjeto e $m$ opções (conforme discutido na seção 5.4). Para estimar a probabilidade complementar do primeiro tem-se:

$$
\begin{aligned}
& p^{\prime} \equiv\left[\frac{u}{\left(1+r_{f}\right)}\right] p \\
& 1-p^{\prime} \equiv\left[\frac{d}{\left(1+r_{f}\right)}\right](1-p)
\end{aligned}
$$

Portanto, chega-se na seguinte igualdade:

$$
p^{n}(1-n)^{T-n} \frac{u^{n} d^{T-n}}{\left(1+r_{f}\right)^{T}}=\left(p^{\prime}\right)^{n}\left(1-p^{\prime}\right)^{T-n}
$$

\footnotetext{
${ }^{49} \mathrm{O}$ equivalente de certeza é o retorno garantido que um investidor aceita agora ao invés de arriscar investir em um retorno maior, porém incerto, no futuro.
} 
Ao final, o modelo binomial para precificar uma call européia, com processo estocástico multiplicativo, fica:

$$
C_{0}=V_{0} B\left(n \geq a \mid T, p^{\prime}\right)-X\left(1+r_{f}\right)^{-T} B(n \geq a \mid T, p)
$$

Onde a é equivalente ao menor inteiro não negativo maior que:

$$
\frac{\ln \left(X / V_{0} d^{n}\right)}{\ln (u / d)}
$$

O limite da fórmula (48) é a fórmula do Modelo de Black-Scholes:

$$
C_{0}=V_{0} N\left(d_{1}\right)-X e^{\left(-r_{f} T\right)} N\left(d_{2}\right)
$$

Onde:

$$
\begin{aligned}
& B\left(n \geq a \mid T, p^{\prime}\right) \rightarrow N\left(d_{1}\right) \\
& B(n \geq a \mid T, p) \rightarrow N\left(d_{2}\right)
\end{aligned}
$$

O modelo binomial para as opções reais resultante é similar ao apresentado na Figura 36, que ilustrou o modelo binomial para as opções financeiras. A resolução do modelo binomial é do tipo 'backward', isso porque, no último período da árvore $t=T$, quando não existe mais a opção de espera, o valor da opção é dado como o máximo valor entre zero e o exercício imediato. Já para os nós entre o nó terminal e o instante $t=0$, o valor da opção é dado pelo máximo valor entre o exercício imediato ou o valor presente da espera, sendo necessário então já se conhecer o valor calculado em $t+1$ para os dois nós filhos.

As fórmulas (16), (17) e (18) apresentadas dentro do Conceito de Opções Financeiras (seção 5.2) são utilizadas sem alterações para a precificação das opções reais. Destaca-se que a fórmula (18) já reflete a probabilidade neutra ao risco. A escolha da formulação de $u$ e $d$ feita por (COX, ROSS e RUBINSTEIN, 1979) faz com que quando o intervalo de tempo tende a um valor muito pequeno, os cenários de $V$ se comportem como uma distribuição lognormal, a qual é utilizada no modelo de Black-Scholes-Merton

Conforme expõe (DIAS, 2014), uma vez que se tenha os valores de $u, d, r$ a precificação do derivativo pode ser dada em três etapas:

1. Gerar a árvore do ativo-objeto $V$;

2. Calcular o valor do derivativo $F(V, t)$ nos nós terminais $(t=T)$;

3. Calcular de forma 'backward' o valor dos derivativos nos nós $t<T$ até o 
4. instante inicial $(t=0)$. Se uma opção americana, então, $F(V, t)=$ Máx[Exercer, Valor presente da espera].

Ainda, no caso dos modelos binomiais multiperiódicos é necessário observar se o ativo analisado em questão é ou não pagador de dividendos, que representa em linhas gerais se o ativo repassa a totalidade ou parte dos seus fluxos de caixa aos seus investidores ou não. Quando se tem um ativo pagador de dividendos, para calcular a probabilidade neutra ao risco, é necessário considerar os dividendos nos fatores $u$ e $d$, dessa forma influenciando na probabilidade neutra ao risco. Tanto (DIAS, 2014) quanto (COPELAND e ANTIKAROV, 2003) abordam essa questão e expõe formas de lidar com os dividendos de diferentes maneiras.

\subsection{Incertezas no Cálculo de Opções}

Diversas incertezas podem ser atribuidas na precificação das Opções Reais. O tramtamento das incertezas, a depender de seu tipo, pode ser considerado de forma consolidada, ou pode ser necessário que as incertezas sejam mantidas separadas. Quando as incertezas são consideradas separadas na precificação dos ativos, pode ser necessária a uitlização do opções compostas (compound options) ou opções arco-íris (rainbow options). Esses dois tipos de opção não serão tratados aqui.

(COPELAND e ANTIKAROV, 2003) sugerem a adoção do método de Monte Carlo para o tratamento das incertezas de forma consolidada. O método de Monte Carlo teve origem em 1949 através do artigo "The Monte Carlo Method" de John von Neumann e Stanislaw Ulam e é utilizado mundialmente para solução de problemas matemáticos cuja solução depenada de fatores aleatórios.

No caso da análise de valor de um projeto, deve-se atentar que a volatilidade do valor do projeto será sempre diferente das volatilidades associadas às variáveis do projeto, assim como, também será diferente da volatilidade do valor da companhia para qual é avaliado. 
SIMULAÇÃO DE MONTE CARLO

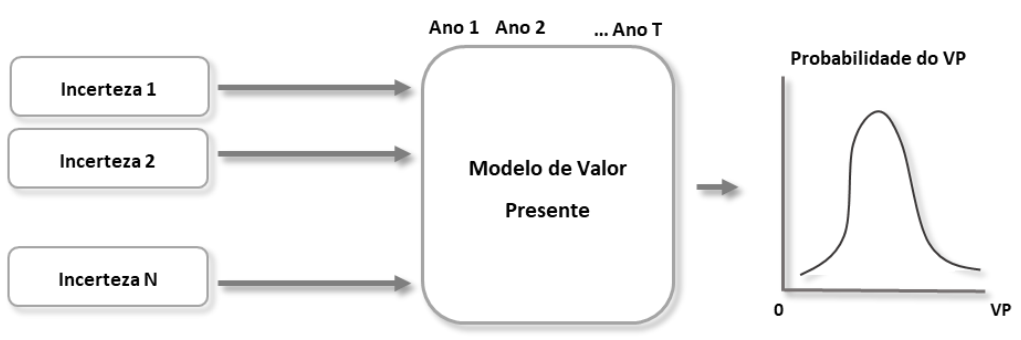

Figura 41:Uso da Simulação de Monte Carlo para um Modelo de Valor Presente

Sendo assim, será utilizada a SMC para calcular volatilidade do projeto, uma vez conhecida a volatilidade de suas variáveis. Conforme exposto em (COPELAND e ANTIKAROV, 2003), a SMC é uma ferramenta simples que permite modelar as correlações entre as variáveis do projeto que abriguem incertezas, conforme ilustra a figura acima.

Para criar a árvore binomial para utilização da TOR, é preciso estimar a volatilidade da taxa de retorno do projeto. Cada conjunto de parâmetros dará origem a um valor presente diferente para o projeto em análise, os quais estão representados na fórmula abaixo pelo acrônimo $V P_{t}$.

Este valor será comparado com o valor presente quando $t=0$. Com estes conjuntos de dados, obtém-se então a volatilidade da taxa de retorno do projeto através da seguinte fórmula:

$$
\ln \left(\frac{V P_{t}}{V P_{0}}\right)=r t
$$

(COPELAND e ANTIKAROV, 2003) descrevem ainda que:

$$
\begin{aligned}
& z=\ln \left(\frac{V P_{1}+F C F_{1}}{V P_{0}}\right) \\
& V P_{1}=\sum_{t=2}^{n} \frac{F C F_{t}}{(1+W A C C)^{t-1}}
\end{aligned}
$$

Outras metodologias para a abordagem de fontes de incerteza são extensamente discutidas em (COPELAND e ANTIKAROV, 2003) e (DIXIT e PINDYCK, 1994). O método utilizado para lidar com as incertezas neste trabalho foi o chamado de "Abordagem Consolidada" (consolidated approach) descrito em (COPELAND e ANTIKAROV, 2003). 
Conforme pontuam os autores, esta abordagem se baseia na filosofia que independente das propriedades estocásticas das variáveis que influenciaram o fluxo de caixa, com base na prova de Samuelson (SAMUELSON, 1965), pode-se construir uma árvore de eventos.

\subsection{Breve Histórico das Opções Reais}

A teoria de precificação de opções foi inicialmente aplicada na avaliação de ativos no ano de 1973 nos trabalhos de (BLACK e SCHOLES, 1973) e (MERTON, 1973). Posteriormente, em 1974, (ARROW e FISHER, 1974) e (HENRY, 1974) publicaram importantes considerações sobre investimentos irreversíveis sob condições de incerteza. A conjunção dessas linhas de pesquisa acabou por originar um grande número de trabalhos que buscavam precificar tais incertezas através da teoria de precificação de opções.

O termo opções reais foi mencionado pela primeira vez em (MYERS, 1977), sendo, portanto, uma metodologia recente de avaliação de investimentos. A ideia de que flexibilidades de investimentos em ativos reais poderiam ser avaliadas de forma análoga às opções financeiras levou ao desenvolvimento de uma vasta gama de trabalhos com diferentes tipos de aplicações para a teoria de opções reais.

No ano de 1979 (TOURINHO, 1979) foi pioneiro em aplicar esta teoria para o estudo do valor de reservas naturais, considerando a incerteza do preço do recurso explorado. Durante a década de 80, a literatura a respeito da TOR se torna mais densa, levando inclusive à publicação de número especial da revista Midland Corporate Finance Journal em 1987, apenas sobre opções reais. Um dos artigos relevantes desta publicação é o de (BRENNAN e SCHWARTZ, 1985) onde é estudada a parada da operação de uma mina de cobre, considerando a incerteza no preço spot e no futuro preço da commoditie. Outra publicação relevante da década de 80 é (MCDONALD e SIEGEL, 1986) sobre a opção de espera.

Só no setor petrolífero, inúmeros trabalhos foram desenvolvidos utilizando a teoria de opções reais. Ainda na década de 80, Paddock, Siegel \& Smith, desenvolveram o trabalho (PADDOCK, SIEGEL e SMITH, 1988), no Laboratório de Energia do MIT, onde avaliaram opções presentes em reservas de petróleo e mostraram empiricamente que em casos como esse a teoria de opções reais oferecia melhores resultados que a metodologia tradicional de fluxo de caixa descontado. 
Em 1990, (BJERKSUND e EKERN, 1990) mostraram, para um campo de petróleo norueguês, que quando há a opção de adiamento do investimento, é possível ignorar paradas temporárias e a opção de abandono. Em 1993, a Shell em parceria com Kemna, desenvolveu o trabalho (KEMNA, 1993), que tinha por objetivo conduzir diversos estudos da aplicação da teoria de opções reais para análise de investimento de novos projetos, de forma alternativa às metodologias tradicionais.

No Brasil, em 1996, Dias utilizou o mesmo modelo de (PADDOCK, SIEGEL e SMITH, 1988) em seu mestrado (DIAS, 1996), para avaliar investimentos sob condições de incerteza na exploração e produção de petróleo. Em 2005, no seu doutorado (DIAS, 2005) tratou de opções híbridas com aplicação na indústria do Petróleo, onde combinou a TOR com teoria dos jogos e teoria de computação evolucionária.

Além da indústria do petróleo, na década de 90 e anos 2000, houve uma diversificação e expansão da literatura sobre opções reais para aplicações nos mais diversos setores da economia. Ademais, neste período, também surgiram os primeiros livros que tratavam exclusivamente sobre a TOR, dentre estes destacam-se (COPELAND e ANTIKAROV, 2003), que possui nível intermediário e (DIXIT e PINDYCK, 1994), sendo este ainda o mais avançado na área.

Devido à caraterísticas tais como elevados investimentos iniciais e longa vida útil, na qual existem flexibilidades operacionais e gerenciais, investimentos no setor elétrico são muitas vezes passíveis de aplicação da TOR. Em 1992, (HERBELOT, 1993) desenvolveu no MIT, um trabalho que trata de opções estratégicas de plantas termelétricas nos EUA para atender ao Clean Air Act Amendments. (TEISBERG, 1994) publicou em 1994 um artigo no qual avalia a construção de uma planta de geração através de um modelo de precificação de opções no valor do investimento de capital. A intenção foi avaliar fatores muitas vezes ignorados por empresas reguladas, como custos recorrentes, irreversibilidade dos investimentos e incertezas regulatórias.

A precificação de opções reais desempenhou um papel importante, inclusive no processo de liberalização dos mercados de energia elétrica ao redor do mundo, em que permitiu que os novos riscos e incertezas associados aos investimentos em geração pudessem ser de alguma forma precificados, conforme propõe o estudo desenvolvido em (FELDER, 1996). 
No ano de 2001, (DENG, JOHNSON e SOGOMONIAN, 2001) foi publicado, onde foi discutida primeiramente a metodologia para precificação de derivativos de energia baseados na construção de portfólios replicantes compostos por contratos futuros de energia e ativos livres de risco e, posteriormente, derivou-se das spark-options e locational-options uma formulação de valuation para ativos de geração e transmissão. Em 2002, o livro (RONN, 2002) foi publicado contendo vinte e um trabalhos relevantes sobre aplicação da TOR no setor energético, focando em decisões de investimento.

No Brasil, em 2003, (MOREIRA, DAVID e ROCHA, 2003) identifica o que levava à ineficácia na sinalização da expansão da oferta através do modelo vigente à época e propondo a avaliação de viabilidade de novos investimentos com opções reais. Em 2004, os mesmos Autores publicaram novo trabalho (MOREIRA, DAVID e ROCHA, 2004), onde discutem a competitividade das termelétricas no Brasil e avaliam através da TOR as condições para investimento.

Uma boa revisão dos trabalhos desenvolvidos com opções reais na análise de investimentos em geração de energia elétrica pode ser encontrada em (FERNANDES, CUNHA e FERREIRA, 2011). Mais recentemente, o artigo (KITZING, JUUL, et al., 2017) expõe uma coletânea dos trabalhos mais relevantes na análise da aplicação da teoria de opções reais nos investimentos em energias renováveis, onde, dentre as incertezas, os regimes de produção das fontes de energia é considerado.

Os trabalhos com opções reais se dividem basicamente em duas técnicas, os que utilizam programação dinâmica e os que utilizam o modelo binomial, conforme será utilizado no presente trabalho. Dentre as pesquisas que utilizam a programação dinâmica revisadas aqui, destacam-se (BøCKMAN, FLETEN, et al., 2008), (BOOMSMA, MEADESTEIN e FLETEN, 2012) e (DÍAZ, MORENO, et al., 2015). Com relação aos trabalhos que utilizam o modelo binomial, destacam-se (DALBEM, BRANDÃO e GOMES, 2014), (HÖRNLEIN, 2019) e (LIU e RONN, 2020). 


\section{ESTUDO DE CASO}

Com base nos conceitos discutidos nas seções anteriores, buscou-se elaborar uma metodologia de cálculo para os produtos Lastro e energia, separadamente, tendo como contexto as necessidades de aprimoramento de desenho de mercado levantadas e as diretrizes já apresentadas pelas autoridades governamentais.

Posteriormente, através da utilização da ferramenta da TOR, a viabilidade dos projetos será avaliada, levando em consideração as fontes de incerteza inerentes à natureza desses projetos.

\subsection{O Preço da Energia}

A precificação de contratos bilaterais comumente comercializados no mercado livre de energia elétrica brasileiro leva em consideração tanto aspectos conjunturais quanto estruturais do setor. Tem-se como boa referência para os aspectos conjunturais o comportamento do PLD e para os aspectos estruturais o Custo Marginal de Expansão (CME).

(RAMOS e SUSTERAS, 2006), (SOKEI, 2008) e (JOELSAS e LYRA, 2015) utilizam técnicas com algoritmos genéticos (AG) para configurar os pesos a serem a dados a diferentes componentes que comporão o preços dos contratos.

Conforme (SOKEI, 2008), os AG seguem o princípio da seleção natural e sobrevivência do mais apto do fisiologista Charles Darwin: "Quanto melhor um indivíduo se adaptar ao seu meio ambiente, maior será sua chance de sobreviver e gerar dependentes."

A motivação para a utilização dos AG surge de sua potencialidade para otimizar processos com características particulares, combinando a busca discricionária e a busca aleatória na procura pelo ponto ótimo da função objetivo. Este tipo de algoritmo facilita a otimização de funções com características não lineares, descontinuidades ou múltiplos picos ou vales.

O modelo proposto pelos autores acima citados utiliza o AG para ponderar, os pesos do PLD e do CME para leilões de energia nova com diferentes prazos de entre de energia, nos diferentes anos em que o contrato está sendo precificado, a partir de uma amostra de centenas ou milhares de contratos praticados no mercado. A composição do preço do contrato em cada ano é dada pelas seguintes fórmulas: 


$$
\begin{aligned}
& P C_{1^{\circ} \text { Ano }}=P L D *\left(1+A_{1}\right) \\
& P C_{2^{\circ} \text { Ano }}=\left(P_{2} * P L D+C E_{2} * C M E_{E E}+C G_{2} * C M E_{G D}\right) *\left(1+A_{2}\right) \\
& P C_{3^{\circ} \text { Ano }}=\left(P_{3} * P L D+C A_{3} * C M E_{A-3}+C G_{3} * C M E_{G D}\right) *\left(1+A_{3}\right) \\
& P C_{4^{\circ} \text { Ano }}=C M E_{A-3} \text { e A-5 } \\
& P C_{5^{\circ} \text { Ano }}=C M E_{A-5}+D_{5}
\end{aligned}
$$

Onde:

$P C_{i}$ : Preço de um contrato de duração de um ano e "delay" de entrega de (i-1) anos;

$A_{i}$ : Porcentagem de ágio aplicada aos valores de PLD para o ano $i$;

$P_{2}, C E_{2}, C G_{2}$ : Participação do PLD, do $C M E_{E E}$ e do $C M E_{G D}$ para a formação do preço no $2^{\circ}$ ano de contrato, sendo a soma destes três fatores igual a $100 \%$;

$C M E_{E E}$ : Representa o preço da energia dos empreendimentos já construídos e que foram ofertados em leilões de energia existente. Por definição, este tipo de empreendimento não representa o custo marginal de expansão, pois caracteriza projetos já construídos. Porém o conceito de CME será utilizado para manter a coerência com os outros anos;

$C M E_{G D}$ : Representa o preço da energia dos empreendimentos de geração distribuída, que tem reduzido tempo de construção e influenciam a formação de preços no curto prazo;

$P_{3}, C A_{3}, C G_{3}$ : Participação do PLD, do $C M E_{A-3}$ e do $C M E_{G D}$ para o 3o ano de contrato, sendo a soma destes três fatores igual a $100 \%$;

$C M E_{A-3}$ : Representa o preço da energia dos empreendimentos comercializados em leilões de energia nova $\mathrm{A} 3$, que tem prazos médios de construção de 3 anos e influenciam a formação de preços a partir do $3 \circ$ ano;

$D_{4}$ : Porcentagem de deságio aplicada aos valores de $C M E_{A-3}$ e $A-5$ para o $4 \circ$ ano de contrato;

$C M E_{A-3 \text { e A-5 }}$ : Preço da energia dos empreendimentos ofertados nos leilões A-3 e A-5. O preço considerado será a média ponderada dos valores negociados nestes certames e influenciará a formação de preços a partir do 40 ano de contrato;

$D_{5}$ : Porcentagem de deságio aplicada aos valores de $C M E_{A-5}$ para o $5 \circ$ ano de contrato e para os demais anos;

$C M E_{A-5}$ : Preço da energia dos empreendimentos ofertados no leilão A-5. Será considerado na formação de preços a partir do $5 \circ$ ano de contrato.

Cabe destacar que os fatores $P_{2}, C E_{2}, C G_{2}, P_{3}, C A_{3}$ e $C G_{3}$ são os pesos determinados por algoritmos genéticos.

Os resultados obtidos e reportados em (JOELSAS e LYRA, 2015) permitem observar que o PLD tem influência na formação dos preços apenas até o 30 ano, sendo esta influência gradativamente diminuída com o passar dos anos. Contudo, a influência dos CMEs, que aparece a partir do $2^{\circ}$ ano, aumenta gradativamente. 
Para cada ano de contrato são analisadas as 2000 séries de CMO resultantes do modelo NEWAVE (NW). A média aritmética de cada um destes cenários mensais, trazidos a valor presente, irá compor o preço do contrato para um determinado mês.

$$
\begin{aligned}
& \text { Preço_VP } P_{j, 1^{\circ} A n o}=\frac{\sum_{k=1}^{n} \frac{\left(P L D_{j, k} *(1+A 1)\right)}{(1+i)^{j}}}{n} \\
& \text { Preço_VP } P_{j, 2^{\circ} A n o}=\frac{\sum_{k=1}^{n} \frac{\left(P L D_{j, k} * P 2+C M E_{\text {Existente }} * C E 2+C M E_{G D} * C G 2\right) *(1+A 2)}{(1+i)^{j}}}{n} \\
& \text { Preço_VP } P_{j, 3^{\circ} A n o}=\frac{\sum_{k=1}^{n} \frac{\left(P L D_{j, k} * P 3+C M E_{A 3} * C A 3+C M E_{G D} * C G 3\right) *(1+A 3)}{(1+i)^{j}}}{n} \\
& \text { Preço_VP } P_{j, 4^{\circ} A n o}=\frac{C M E_{A-3 e A-5} *(1-D 4)}{(1+i)^{j}} \\
& \text { Preço_VP } P_{j, 5^{\circ} A n o}=\frac{C M E_{A-5} *(1-D 5)}{(1+i)^{j}}
\end{aligned}
$$

Onde:

Preço_VP $P_{j}$ : Valor presente do preço do mês $j$;

$i$ : Taxa mensal de atualização do capital;

j: Mês do preço;

$n$ : Série de PLD.

Como resultado deste processo, pode-se obter uma sequência de diferentes preços de contratos no tempo. Utilizando o conceito do fluxo de caixa equivalente, o valor do contrato é obtido igualando-se todas as entradas e saídas do fluxo de caixa. O preço obtido é o 'equivalente econômico' de um contrato que tivesse a mesma duração e preços escalonados ao longo do período de contratação.

Como resultado dessa análise, foram obtidos os seguintes valores médios de contratos para os anos de 2021 a 2023.

Tabela 11: Preços de Energia no Mercado de Curto Prazo (R\$/MWh)

\begin{tabular}{c|c} 
Ano & $\mathrm{R} \$ / \mathrm{MWh}$ \\
\hline 2021 & 182,99 \\
2022 & 165,98 \\
2023 em diante & 157,18
\end{tabular}

Fonte: Autora 


\subsection{O Preço do Lastro}

Conforme já exposto aqui, apesar de colocar a separação dos produtos Lastro e Energia como diretriz para a modernização do mercado brasileiro nos próximos anos, as autoridades governamentais não apresentaram uma metodologia em que se definisse qual poderia vir a ser o preço destes produtos em separado. Neste contexto, portanto, este trabalho busca avaliar do ponto de vista da financiabilidade, qual deveria ser o preço de venda da produção de energia, de maneira a recuperar tanto o custo de investimento, quanto os custos de operação e manutenção destes parques.

Dado o desenho de mercado atual, entende-se que o preço de energia comercializado nos leilões do ACR acaba por englobar os custos dos produtos Lastro e energia como um único pacote, sendo que estes valores são suficientes para remunerar o investimento realizado, assim como para operar o parque. Na última seção, foi precificado o valor que os consumidores estariam dispostos a pagar pela energia no mercado livre. Aqui, nesta seção, busca-se precificar o valor do Lastro através da mensuração do custo não recuperado pelo investidor no mercado livre, e que, por conseguinte, poderia ser recuperado através de leilões centralizados realizados pelo planejador central.

Nessa perspectiva, a lógica aqui é tal que o governo continuaria realizando leilões centralizados, no caso Leilões de Lastro, para os quais estipularia um preço teto para o Lastro de cada tipo de fonte, sendo que os empreendedores apresentariam deságios, conforme a competitividade das condições de investimento em novas plantas que encontrassem no mercado. Estes contratos de Lastro teriam a duração similar às praticadas nos contratos comercialização regulados negociados hoje em dia nos leilões de energia nova, contribuindo substancialmente para a obtenção de financiamentos para novos projetos.

Frisa-se que os valores de Lastro apresentados aqui estarão em $\mathrm{R} \$ \mathrm{MWh}$, para facilitar o entendimento e comparação com os valores de energia praticados no mercado. Contudo, é de se esperar que quando efetivamente comercializados, estejam expressos em R $\$ / M W$, o que muda substancialmente a ordem de grandeza do valor.

Assim, foram elaboradas análises de fluxo de caixas de projetos, para diferentes tipos de fontes, com base em parâmetros de mercado discutidos na seção Valuation deste trabalho. 
Uma vez obtidos tanto o Fluxo de Caixa do Projeto do Acionista, para cada uma das fontes, foram calculadas sensibilidades tanto entre a taxa interna de retorno (TIR) do acionista, ou como conhecido em inglês como Equity Internal Rate of Return (Equity IRR), com relação ao custo do Lastro para que tal retorno pudesse ser atendido.

$$
0=V P L=\sum_{t=0}^{T} \frac{F C_{t}}{(1+T I R)^{t}}
$$

Onde:

$F C_{t}$ : São os fluxos de caixa em cada período $t$;

$V P L$ : É o valor presente líquido;

TIR: É a taxa interna de retorno.

Deve-se destacar que subsídios e isenções fiscais foram descartados das análises, em virtude do entendimento de que existe uma tendência de eliminação destes, conforme o observado amadurecimento das fontes renováveis, frente às demais, nos leilões realizados pelo governo. Além disso, incentivos regionais, como Sudam e Sudene também não foram considerados, devido à intenção de que o cálculo representasse um custo global, ou seja, independentemente da localidade das fontes.

Além disso, outras formas de receita, que podem surgir no futuro, viabilizadas pela introdução do preço horário de energia no Brasil, que estariam ligadas ao fornecimento de produtos relacionados à confiabilidade do fornecimento de energia, também não foram considerados, dado o nível de complexidade para seu cálculo, a qual não está compreendida no escopo de análise desta dissertação.

Entende-se também que, no limite, se todos os atributos das fontes fossem reconhecidos economicamente e comercializados no mercado, não haveria necessidade de comercializar o Lastro da maneira aqui proposta, pois todo o custo de investimento poderia ser recuperado e remunerado através da comercialização de diferentes produtos no mercado livre. De certo que, para tal, são necessários (i) a existência de um mercado completamente aberto, livre e amadurecido, (ii) uma maior granularidade e (iii) sinalização locacional nos preços praticados.

\subsubsection{Premissas}

As premissas adotadas para o cálculo do valor do Lastro estão em linha com os valores discutidos na seção 6 e são apresentados na tabela a seguir: 
Tabela 12: Premissas para o Estudo de Caso Estático

\begin{tabular}{|c|c|c|c|c|c|c|}
\hline & $\begin{array}{c}\text { CAPEX } \\
\text { (MN } \\
\text { US\$/MW) }\end{array}$ & $\begin{array}{c}\text { O\&M FIXO } \\
\text { (US\$/KW/ANO) }\end{array}$ & $\begin{array}{l}\text { O\&M VAR. } \\
\text { (US\$/MWH) }\end{array}$ & $\begin{array}{c}\text { FATOR DE } \\
\text { CAPACIDADE } \\
(\%)\end{array}$ & $\begin{array}{l}\text { VIDA ÚTIL } \\
\text { (ANOS) }\end{array}$ & $\begin{array}{c}\text { CONSTRUÇã } \\
\text { O (ANOS) }\end{array}$ \\
\hline EÓLICA & 1,2 & 25 & - & $45 \%$ & 20 & 2 \\
\hline SOLAR & 1,0 & 16 & - & $35 \%$ & 20 & 1 \\
\hline $\mathrm{PCH}$ & 2,1 & 23 & - & $55 \%$ & 30 & 3 \\
\hline UHE & 1,8 & 15 & - & $55 \%$ & 30 & 5 \\
\hline $\begin{array}{l}\text { TERM. A GÁS NATURAL - } \\
\text { GNL }\end{array}$ & 1,0 & 12 & 3 & $90 \%$ & 20 & 5 \\
\hline $\begin{array}{l}\text { TERM. A GÁS NATURAL - } \\
\text { PRÉ-SAL }\end{array}$ & 1,3 & 12 & 3 & $90 \%$ & 20 & 5 \\
\hline TERM. A BIOMASSA* & 1,5 & 31 & - & $80 \%$ & 20 & 3 \\
\hline
\end{tabular}

Com relação aos casos a serem analisados, destaca-se que as termelétricas movidas a gás natural são do tipo Ciclo Combinado. Além disso, assume-se que o combustível que alimentará a termelétrica movida a biomassa é do tipo Cavaco de Madeira.

Com relação ao custo de combustível, para a termelétrica movida a gás natural proveniente de terminal de regaseificação, considera-se um custo de $\mathrm{R} \$ 260 / \mathrm{MWh}$. Já para as térmicas que serão abastecidas com gás proveniente do Pré-Sal, considerou-se um custo de combustível de $\mathrm{R} \$ 194 / \mathrm{MWh}^{50}$. Para a usina movida a biomassa, o custo de combustível considerado foi de R\$120/MWh.

Para todas as fontes, foram considerados PIS e COFINS com alíquota total de 9,25\%, imposto sobre a renda de $34 \%$, TUST de R $\$ 7,68 / \mathrm{kW}$-mês, além de outros tributos e encargos competentes a cada uma das fontes.

\subsubsection{Resultados}

Considerado as premissas pontuadas na seção anterior, modelos de FCD foram construídos e simulados para cada uma das fontes, permitindo assim o cálculo da TIR. Destaca-se que as TIR apresentadas são referentes à remuneração do acionista ('Equity $\left.I R R^{\prime}\right)$ e estão em termos nominais. Destaca-se aqui, conforme já mencionado anteriormente, que os resultados não consideram qualquer tipo de subsídio ou benefício fiscal, independentemente do tipo da fonte. A tabela e o gráfico a seguir resumem os resultados obtidos.

${ }^{50}$ Fonte: (EPE, 2019b) 
Tabela 13: Resultados para o Preço-teto do Lastro (R\$/MWh) para diferentes Taxas de Retorno do Acionista

\begin{tabular}{|c|c|c|c|c|c|c|c|c|c|}
\hline & $12 \%$ & $13 \%$ & $14 \%$ & $15 \%$ & $16 \%$ & $17 \%$ & $18 \%$ & $19 \%$ & $20 \%$ \\
\hline EÓLICA & 42 & 50 & 58 & 66 & 74 & 83 & 91 & 100 & 109 \\
\hline SOLAR & 55 & 62 & 70 & 78 & 86 & 94 & 102 & 111 & 119 \\
\hline PCH & 72 & 85 & 99 & 114 & 128 & 142 & 158 & 174 & 190 \\
\hline UHE & 44 & 58 & 71 & 86 & 101 & 117 & 133 & 150 & 166 \\
\hline $\begin{array}{l}\text { TERM. A GÁS NATURAL - } \\
\text { GNL }\end{array}$ & 230 & 234 & 238 & 243 & 247 & 252 & 257 & 263 & 268 \\
\hline $\begin{array}{l}\text { TERM. A GÁS NATURAL - } \\
\text { PRÉ-SAL }\end{array}$ & 170 & 175 & 181 & 186 & 193 & 199 & 206 & 213 & 220 \\
\hline TERM. A BIOMASSA & 113 & 119 & 125 & 132 & 138 & 145 & 152 & 159 & 166 \\
\hline
\end{tabular}

Fonte: Autora

Os resultados estão expostos também em forma de gráfico na figura abaixo:

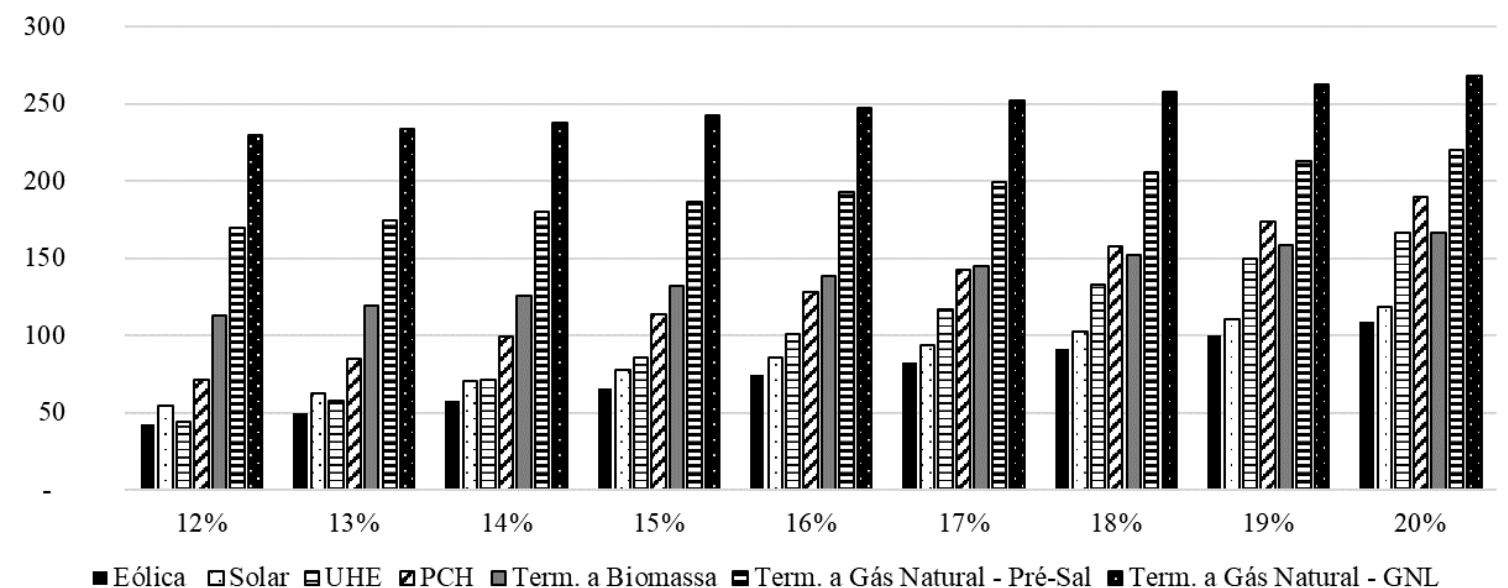

Figura 42: Resultados para o Preço-teto do Lastro (R/MWh) para diferentes Taxas de Retorno do Acionista

Fonte: Autora

\subsection{Análise de Investimento sob a Óptica das Opções Reais}

Nesta seção será avaliada a opção de um empreendedor investir em uma planta hidrelétrica e numa combinação de uma planta hidrelétrica com uma planta eólica. Serão consideradas variáveis estocásticas deste processo os volumes de geração hidrelétrica e eólica, assim como o preço de curto prazo da energia elétrica (PLD).

\subsubsection{Preços de Lastro e Energia}

O investidor estará inserido no contexto em que os produtos Lastro e Energia já são comercializados separadamente e, portanto, em ambas as situações os retornos dos projetos contemplados pelo investidor serão avaliados para diferentes valores de Lastro. 
Nesse contexto será então possível avaliar o impacto que o produto Lastro terá sobre o projeto, considerando-se o produto Lastro como um contrato de longo prazo, de período similar ao da concessão e com valor fixo reajustado pelo IPCA. Para fins de facilitar a comparação com os valores de energia praticados hoje, os valores de Lastro, assim como nas seções anteriores, serão expostos em $\mathrm{R} \$ / \mathrm{MWh}$, contudo, idealmente, estes valores deveriam ser grafados em R $\$ / M W$.

O preço da energia, que é uma das variáveis estocásticas utilizadas aqui, foi simulado através do Modelo Estratégico de Geração Hidrotérmica a Subsistemas Equivalentes Interligados (NEWAVE) $)^{51}$.

Conforme (STREET, LIMA, et al., 2012), com relação aos preços de curto prazo, no Brasil verifica-se que são muito dependentes da política de operação adotada e, por essa razão, modelos de longo prazo são considerados os melhores tipos de modelos de simulação para esta projeção no caso brasileiro, pois preservam as características dinâmicas de longo prazo desta variável. Ou seja, utilizando a projeção de preços do modelo NEWAVE, respeita-se a dependência temporal das séries de preço de curto prazo, independentemente deste continuar possuindo alta volatilidade. Destaca-se a seguir alguns trabalhos relevantes que utilizam dados NEWAVE para fazer análises com opções reais no SEB.

Um exemplo de utilização do NEWAVE em análise de investimento com Opções Reais é o trabalho (GOMES, BAIDYA e MELO, 2001). Os autores avaliam o investimento em Termelétricas no Brasil com uso de Opções Reais utilizando como uma das incertezas a hidrologia. Nesse caso, o despacho do modelo NEWAVE é considerado na obtenção dos Fluxos de Caixa a serem considerados na avaliação do projeto.

Outro exemplo relevante de aplicação dos dados do NEWAVE em análises no SEB é (MARRECO, 2007). A autora propõe uma análise do planejamento da expansão de longo prazo sob a ótica da TOR. Dentre as análises apresentadas, a autora avalia a flexibilidade operacional do sistema com a TOR utilizando todos os parâmetros de entrada provenientes de simulações do NEWAVE.

\footnotetext{
${ }^{51}$ O NEWAVE é um modelo do Centro de Pesquisa de Energia Elétrica (CEPEL) que, auxilia na determinação da estratégia de operação ótima do sistema hidrotérmico brasileiro no horizonte de médio e longo prazo. Neste modelo é utilizada a Programação Dinâmica Dual Estocástica (PDDE), a qual permite que a estratégia ótima de operação seja determinada depois que todas as possibilidades de combinações entre níveis de reservatórios e tendências hidrológicas já foram calculadas. Além disso, o modelo discretiza o horizonte de planejamento em estágios temporais mensais.
} 
(BATISTA, 2007) também utiliza os dados do modelo NEWAVE para estimar o valor incremental do mercado de carbono nos projetos de fontes renováveis de geração no SEB, sendo que o gráfico que se segue ilustra o comportamento da média e de percentis das séries de PLD utilizadas para fins de simulação do estudo de caso:

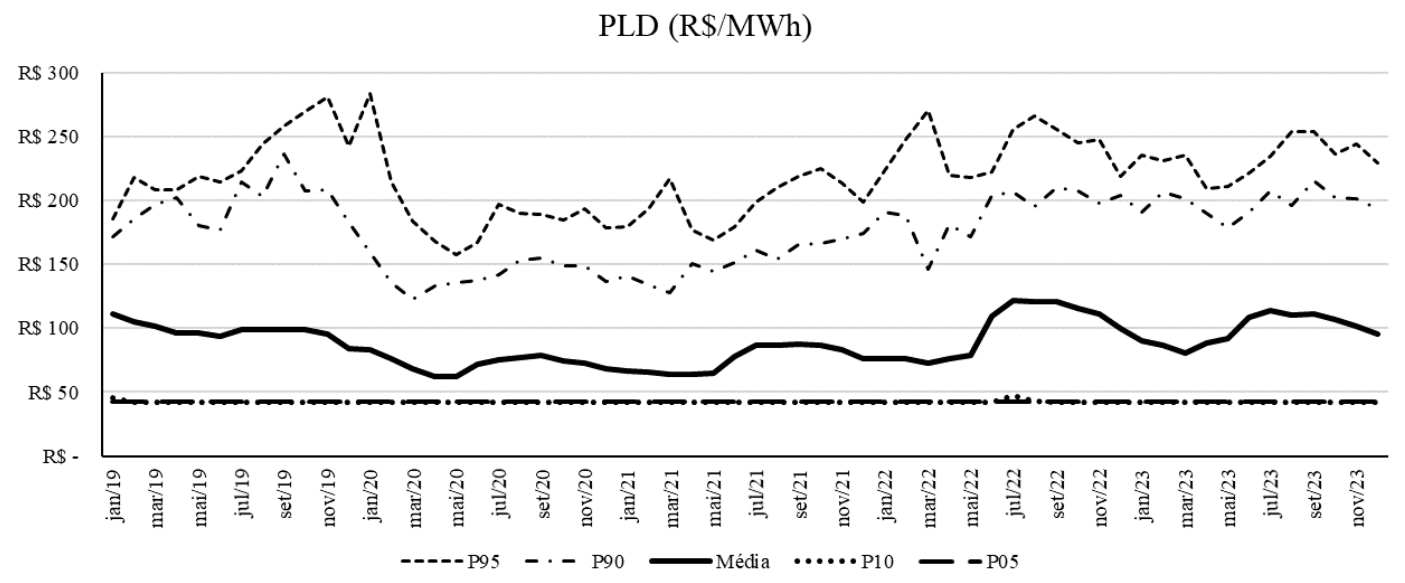

Figura 43: Média e Percentis das séries de PLD utilizadas na simulação Fonte: Autora

Assim como aplicado por (GOMES, BAIDYA e MELO, 2001), para os preços de contratação foi desenvolvida uma fórmula que faz os preços dos contratos variarem conforme o comportamento do PLD, contudo, impõe-se que a média continue seguindo um preço médio de comercialização. Dessa forma é possível refletir no preço de comercialização da energia de médio prazo as expectativas que os agentes têm para a evolução do preço de curto prazo.

\subsubsection{Geração Hidráulica e sua Comercialização}

Por contar com despacho centralizado e determinado pelo ONS, no Brasil as usinas hidrelétricas não controlam seus níveis de produção de energia. O despacho é otimizado no tempo e no espaço (cascatas de geração hidrelétrica) com o intuito de minimizar os custos de operação do sistema, visando a obtenção do menor custo marginal possível.

Em razão de o despacho centralizado não respeitar os compromissos contratuais das usinas hidrelétricas, o mercado brasileiro de energia conta com o Mecanismo de Realocação de Energia (MRE), o qual foi criado com o intuito de mitigar os riscos financeiros dos agentes hidrelétricos provenientes do descasamento entre a operação e o universo contratual. 
O MRE funciona como um pool, onde a energia gerada individualmente pelas hidrelétricas é realocada entre as participantes, de forma que ao final todas tenham um volume de produção de energia para fins de apuração no mercado de curto prazo, proporcional às suas garantias físicas. Sendo assim, o risco de produção de energia de uma hidrelétrica participante do MRE é igual para todos e está atrelado ao volume de produção total do pool do MRE ser superior ou inferior a soma das garantias físicas das usinas participantes. À relação entre o volume de energia efetivo produzido pelo pool do MRE e a soma das garantias físicas das usinas participantes, dá-se o nome de Generation Scaling Factor (GSF).

A hidrelétrica considerada para fins desta análise é participante do Mecanismo de Realocação de Energia (MRE). Portanto, o risco atrelado ao seu volume de produção de energia será verificado através da sua exposição ao mercado de curto prazo, dado pelo impacto que GSF terá sobre sua necessidade de compra ou venda de energia. Os cenários de geração foram extraídos do modelo NEWAVE. Os cenários de GSF considerados aqui estão expostos no gráfico a seguir:

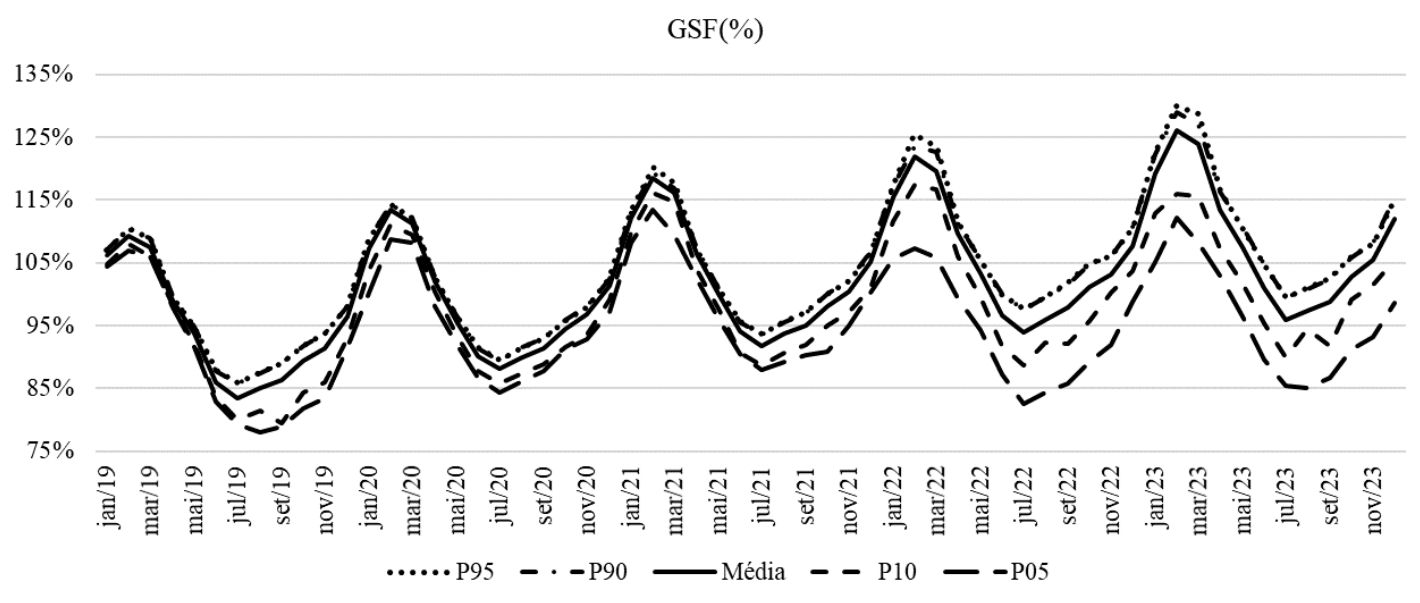

Figura 44: Média e Percentis dos cenários de GSF

Fonte: Autora

\subsubsection{Geração Eólica e sua Comercialização}

Originalmente, no modelo NEWAVE a geração das usinas eólicas está representada de maneira determinística dentro de um bloco de usinas 'não simuladas' que é abatido diretamente da carga para fins de simulação. A definição do valor de geração das usinas não simuladas e fora, portanto, do Despacho Centralizado, é regrada pela Resolução Normativa ${ }^{\circ}$ 843/2019. 
O volume de geração utilizado para o cálculo do valor determinístico adotado no bloco de usinas não simuladas se dá com base nos valores mensais verificados de geração dos últimos cinco anos, tendo por base uma janela móvel que é atualizada em todo mês de maio. Sendo assim, para as usinas que já estão em operação, no planejamento da operação futura, é considerado que ela gerará o mesmo que gerou nos últimos cinco anos. Para as usinas que entrarão em operação comercial no horizonte de simulação, considerase um fator de capacidade a ser aplicado sobre sua placa similar ao fator de capacidade que vem sendo desempenhado na janela móvel de geração verificada.

Para poder representar de maneira estocástica a fonte eólica no modelo NEWAVE, criam-se bacias eólicas dentro do modelo, onde já são modeladas as bacias hidráulicas. Dessa forma, utiliza-se o já consolidado modelo auto-regressivo interno ao NEWAVE para a geração das séries sintéticas de vento. A metodologia aqui utilizada para a construção das séries históricas e vento e inserção das mesmas no modelo NEWAVE foi amplamente discutida nos (WITZLER, 2015), (MACHADO, 2016) e (MUMMEY, 2017).

(WITZLER, 2015) tem como principal objetivo a reconstrução das séries históricas de vento, permitindo o estudo aprofundado do comportamento do que seria a Energia Natural Afluente Eólica entre os anos de 1948 a 2010. Para tal, o autor avalia o comportamento das séries de vento de longo prazo nas regiões do o Ceará, Rio Grande do Norte, Bahia, São Paulo e Rio Grande do Sul.

(MACHADO, 2016) avalia a geração de cenários hidro-eólicos utilizando o modelo auto-regressivo periódico (PAR) para o problema do planejamento da operação energética de médio prazo, em que testes de especificação do modelo são realizados nas séries históricas e nas séries sintéticas geradas.

(MUMMEY, 2017) detalha uma possível alteração no modelo NEWAVE para a tornar possível a inserção da fonte eólica, considerando a geração de séries históricas e sintéticas. Essa alteração permite que se proceda uma avaliação de impacto da representação estocástica da geração eólica nos níveis de despacho e na formação de preços no SIN. Numa primeira etapa, para a reconstrução das séries temporais de vento faz-se uma reconstituição da série diária com base nas características da série Vortex, onde é feita uma extrapolação vertical para a altura de interesse (altura do eixo do rotor) e uma análise estatística a partir da velocidade horária. 
Posteriormente, com a série NCAR, calcula-se o expoente da Lei de Potência (n), para o deslocamento da série na altura do aerogerador, com remoção de outliers, para posteriormente realizar também uma análise estatística. Ao final, a reconstrução das séries diárias é feita a partir da variabilidade diária do NCAR, e da velocidade média do Vortex. A figura abaixo ilustra o processo descrito acima:

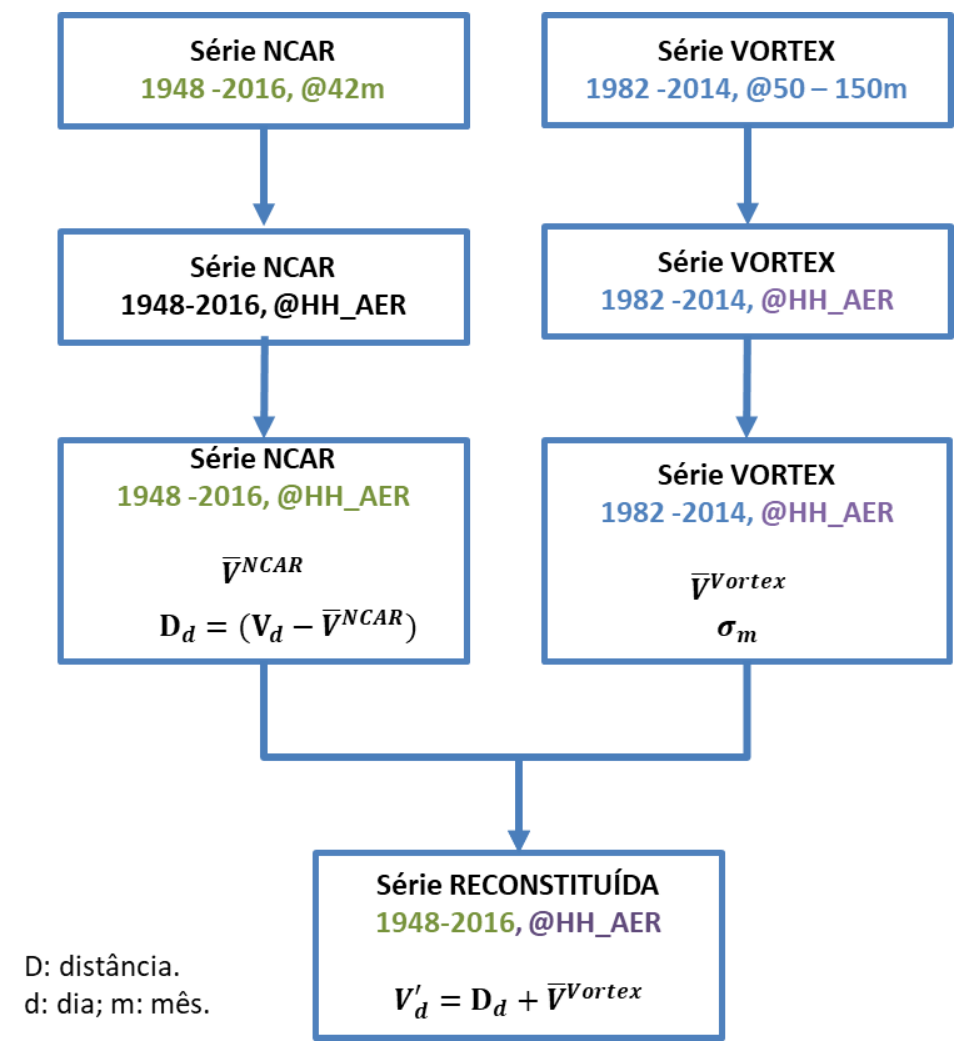

Figura 45: Reconstrução de Séries Temporais de Vento - Etapa I.

Fonte: MRTS Consultoria

Na segunda etapa, calcula-se a geração diária com a série histórica reconstituída. É calculada uma distribuição de Weibull para cada dia, em que se aplica a velocidade diária reconstruída e o desvio padrão mensal para definiç̧ão da distribuição. A partir daí, cruza-se a distribuição de Weibull com a Curva de Potência do aerogerador (AER) selecionado.

Para fins de análise desse estudo de caso, foram simuladas as séries de geração para a usina Morro de Chapéu, no Estado da Bahia. O gráfico a seguir ilustra o comportamento estatístico das séries de geração utilizadas. 


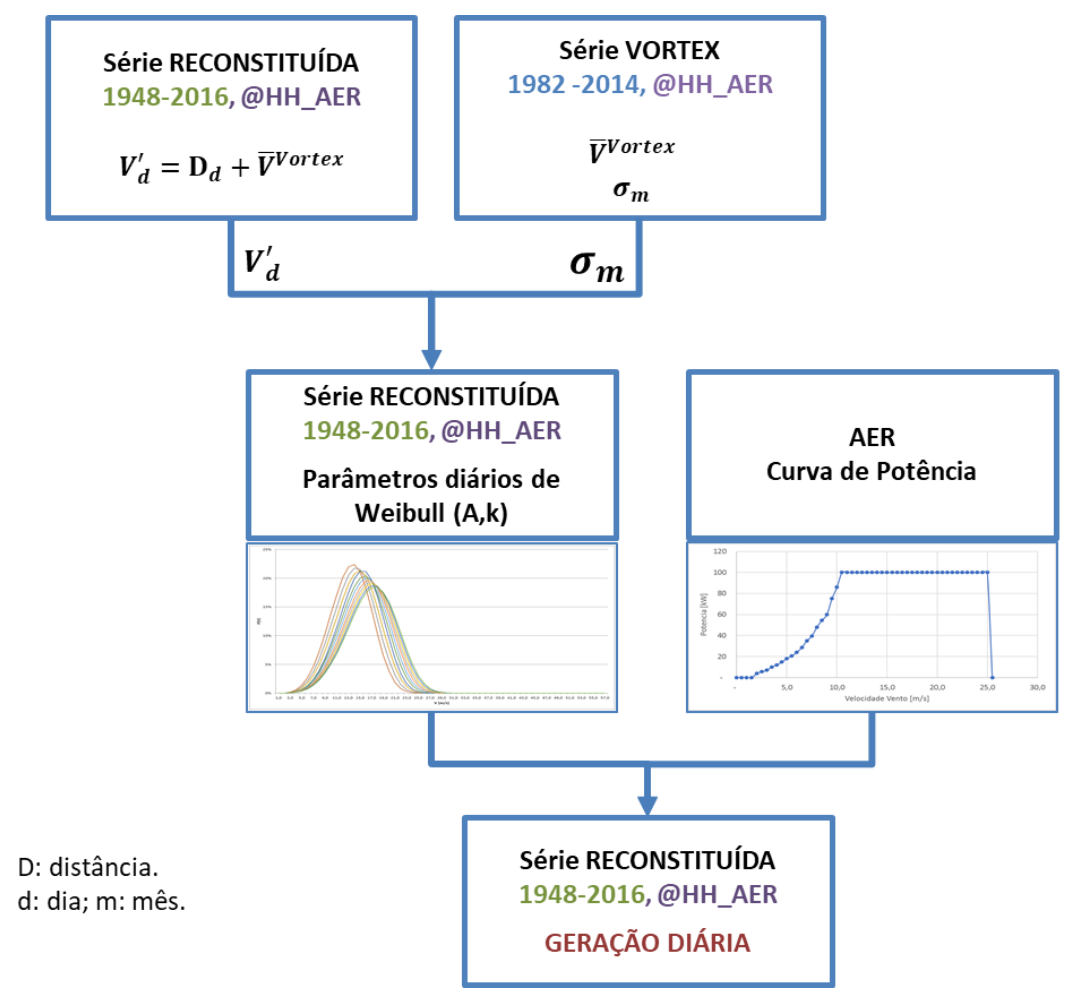

Figura 46: Geração diária com série reconstituída - Etapa II.

Fonte: MRTS Consultoria

Geração Eólica (p.u. de Potência)

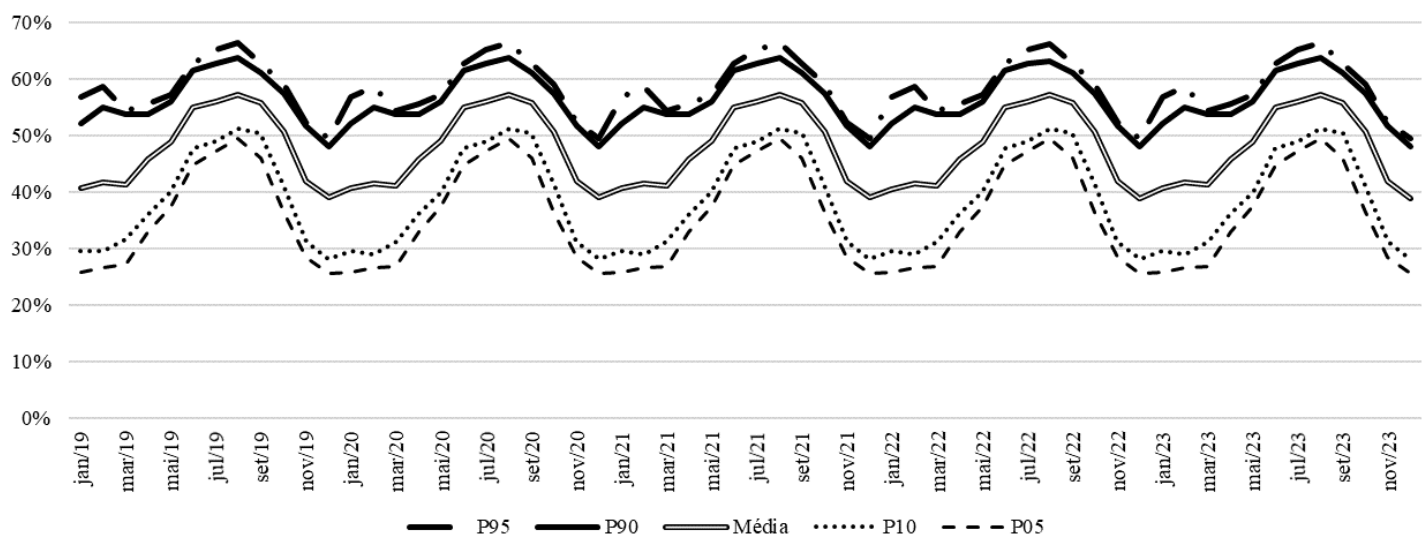

Figura 47: Média e Percentis da Geração Eólica Por Unidade de Potência.

Fonte: Autora

Para fins do estudo de caso deste relatório, o contrato da central geradora eólica será considerado como contrato do tipo quantidade, conforme vem sendo praticado nos últimos Leilões de Energia Nova. 


\subsubsection{O Valor de Adiar o Investimento (Opção de Espera)}

O valor de esperar para realizar um investimento reside em avaliar se as condições futuras acerca de um investimento tornariam algum momento mais propício para realizálo do que no presente. Considerando que um projeto tenha uma expectativa de geração de fluxos de caixa futuro $V_{0}$ e que requeira um investimento de $X$ para que seja realizado, seu $V P L$ será dado por:

$$
V P L=V_{0}-X
$$

A opção de esperar para realizar um investimento tem o mesmo comportamento que uma call americana (onde o exercício da opção pode ser realizado a qualquer momento), o preço de exercício dessa call é o investimento necessário $X$, o prazo de vencimento é o período que a empresa pode esperar para realizar o investimento e o ativobase é o próprio projeto.

A análise de uma opção de espera é propícia para o estudo de caso a ser apresentado aqui, pois, considerando as variáveis estocásticas que estão em análise, como o preço da energia, a espera por condições melhores de mercado pode adicionar valor ao investimento.

Como referência para análise da opção de espera foram observados os trabalhos de (TRIGEORGIS, 1995), (GOMES, BAIDYA e MELO, 2001), (MEIRELLES, 2004) e (NUNES, 2017), os quais fazem análises e aplicações de opção de espera de um investimento utilizando o modelo binomial, conforme se propõe também aqui.

Nos estudos de caso a serem apresentados a seguir, o período de avaliação de espera do investimento é de até T anos. Sabendo que:

$$
C=C(V, I, r f, \sigma, T, N)
$$

Onde:

$$
\begin{aligned}
& C: \text { Valor da Call Americana; } \\
& V: \text { Valor do Projeto; } \\
& I: \text { Valor do Investimento; } \\
& r_{f}: \text { Taxa livre de risco; } \\
& \sigma: \text { Volatilidade implícita; } \\
& T: \text { Tempo até o vencimento da opção; } \\
& N \text { : Número de períodos em } \mathrm{T} .
\end{aligned}
$$


Primeiramente constrói-se uma árvore de eventos, em que se se tenha o valor do ativoobjeto em análise, que no caso representa os valores esperados dos projetos passíveis de investimento. $\mathrm{O}$ valor do projeto se expandirá pela árvore com base nos fatores multiplicativos $u$ e $d$, os quais trazem ao projeto o impacto da volatilidade implícita resultante da combinação da volatilidade das variáveis estocásticas, conforme descrito na seção 5.6. Destaca-se que o ativo observado é não pagador de dividendos. A árvore de eventos fica da seguinte forma:

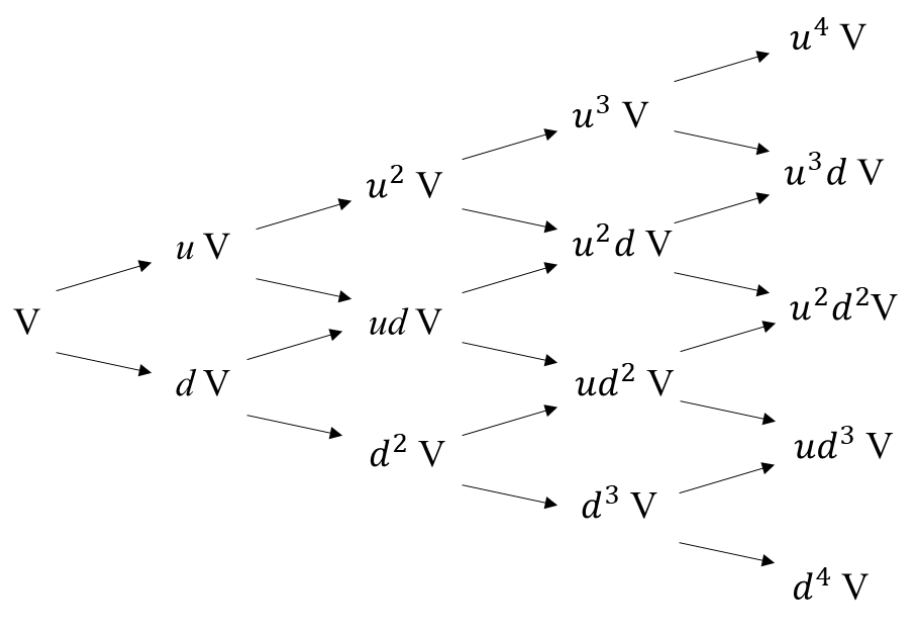

Figura 48: Árvore de Eventos do Estudo de Caso

Fonte: Autora

A precificação da Call Americana será realizada então com base nos valores de projeto calculados na árvore de eventos. No último ano, o valor da Call é dado por:

$$
C_{T, V_{T}}=\text { Máximo }\left\{V_{T}-I ; 0\right\}
$$

Já nos demais anos, utilizando a metodologia de precificação do Portfólio sem Risco, a formulação será dada por:

$$
C_{t<T, V_{t}}=\text { Máximo }\left\{\frac{u C_{t+\Delta t}^{d}-d C_{t+\Delta t}^{u}}{(u-d)\left(1+r_{f}\right)}+\frac{C_{t+\Delta t}^{u}-C_{t+\Delta t}^{d}}{(u-d)} ; V_{t}-I\right\}
$$

Onde:

$$
\begin{aligned}
& u=e^{\sigma \sqrt{\Delta T}} \\
& d=e^{-\sigma \sqrt{\Delta T}}
\end{aligned}
$$


Conforme (MEIRELLES, 2004), que cita (DIXIT e PINDYCK, 1994), a opção de adiar um investimento pode ser vista como o custo de oportunidade do investimento. $\mathrm{Ou}$ seja, investir hoje significaria anular essa opção, devendo a empresa pagar por esse custo de oportunidade juntamente com o investimento inicial. Sendo assim, para que um investimento seja viável em t não é suficiente que se tenha apenas o VPL tradicional positivo, mas sim que exceda o investimento somado ao custo de oportunidade.

Para melhor entendimento, convém exemplificar aqui a opção de espera em uma situação simples, para clarificar a aplicação. O exemplo é retirado integralmente do estudo apresentado em (GOMES, BAIDYA e MELO, 2001).

Deseja-se realizar um investimento que requer um capital inicial $I$ de $\mathrm{R} \$ 4.000$. O projeto irá produzir anualmente, e na perpetuidade, kits que possuem um preço inicial $P_{0}$ de $\mathrm{R} \$ 500$. Além disso, o projeto não apresenta custos operacionais. O preço do kit sofrerá reajuste exclusivamente em $t=1$, com a probabilidade de $50 \%(u=0.5)$ de atingir preço de $P_{1, u}$ de $\mathrm{R} \$ 750$, ou $50 \%$ de cair $(d=0.5)$ para $P_{1, d}$ de $\mathrm{R} \$ 250$. Nesse caso a taxa de desconto é $10 \%$ e o investimento é capitalizado também a $10 \%$.

Em $t=0$ tem-se que o Valor Presente dos Fluxos de Caixa do projeto $V_{0}$ é a soma de $P_{0}$ e da Expectativa do valor de $V_{1}\left(E_{0}\left(V_{1}\right)\right)$. Portanto, $V_{0}$ é $\mathrm{R} \$ 5.500$ conforme a formulação abaixo:

$$
V_{0}=P_{0}+E_{0}\left(V_{1}\right)=P_{0}+\frac{P_{0}}{r}=5000+\frac{5000}{0,1}=5.500
$$

Portanto o Valor Presente Líquido do projeto em $t=0$ é:

$$
V P L_{0}=V_{0}-I_{0}=5.500-4000=1.500
$$

Agora observa-se o valor da flexibilidade de se investir em $t=1$. A oportunidade de investimento $(F)$ será dada pelo maior valor entre não investir e o valor líquido do investimento que é $V-I$, em ambas as situações, ou seja, caso o preço suba $F_{1, u}$ ou caia $F_{1, d}$

$$
\begin{gathered}
V_{1, u}=750+\frac{750}{0,1}=8.250 \\
F_{1, u}=\operatorname{Máx}\left(0, V_{1, u}-I_{1}\right)=\operatorname{Máx}(0,8.250-4.400)=3.850
\end{gathered}
$$




$$
\begin{gathered}
V_{1, d}=250+\frac{250}{0,1}=2.750 \\
F_{1, d}=\operatorname{Máx}\left(0, V_{1, d}-I_{1}\right)=\operatorname{Máx}(0,2.750-4.400)=0
\end{gathered}
$$

O valor dessa oportunidade de investimento em $t=1$, vista em $t=0$ é de:

$$
\frac{E_{0}\left(F_{1}\right)}{1+r}=\frac{u * F_{1, u}+d F_{1, d}}{1+r}=1.750
$$

Conclui-se que é melhor esperar para realizar o investimento em $t=1$, dado que o VPL com a opção de espera $\left(V P L_{O R}\right)$ do projeto nesse caso pode ser de R $\$ 1.750$ e o VPL tradicional $\left(V P L_{T}\right)$ é de $\mathrm{R} \$ 1.500$. Portanto a opção de esperar $(V O R)$ nesse caso é de $\mathrm{R} \$ 250$, sendo esse o custo de oportunidade do investimento imediato.

$$
\begin{gathered}
V P L_{O R}=V P L_{T}+V O R \\
V O R=R \$ 1.750-R \$ 1.500=R \$ 250
\end{gathered}
$$

O método utilizado para lidar com as incertezas neste trabalho foi o chamado de "Abordagem Consolidada" (consolidated approach) descrito em (COPELAND e ANTIKAROV, 2003). Conforme pontuam os autores, esta abordagem se baseia na filosofia que independente das propriedades estocásticas das variáveis que influenciaram o fluxo de caixa, com base na prova de Samuelson (SAMUELSON, 1965), pode-se construir uma árvore de eventos.

\subsubsection{Análise de Investimento em uma Hidrelétrica}

O primeiro estudo de caso a ser realizado analisa o investimento em uma usina hidrelétrica, quando há a opção de adiar o investimento por um período de até 4 anos. Neste estudo de caso, tem-se como variáveis estocásticas a produção hidrelétrica do SIN e o preço da energia.

Considerou-se aqui uma hidrelétrica de 300 MW de potência, com 165 MWm de garantia física e participante do MRE. O valor do investimento considerado para este empreendimento foi de $\mathrm{R} \$ 2.073,60$ milhões, em linha com as premissas adotadas na seção anterior. A usina pode comercializar a energia de duas formas: (i) Lastro e/ou (ii) Energia. Portanto, variou-se o valor que a usina pode comercializar de Lastro, de zero a R\$140/MWh, para avaliar qual o impacto que a comercialização de Lastro tem no valor do negócio. 
As premissas de custo de investimento e O\&M são as mesmas adotadas na seção anterior, onde se calculou o preço teto do Lastro.

Num primeiro momento, foi calculado o Valor Presente do Projeto, variando os valores do Lastro de zero a $\mathrm{R} \$ 140 / \mathrm{MWh}$, mantendo as variáveis estáticas, sendo esse o caso base, ou seja, quando não há nenhuma flexibilidade. Os valores presentes do projeto encontrados são dados conforme o gráfico abaixo:

Valor Presente do Projeto Hidrelétrico sem Flexibilidade para Diferentes Valores de Lastro $(\mathrm{mn} \mathrm{R} \$$ )

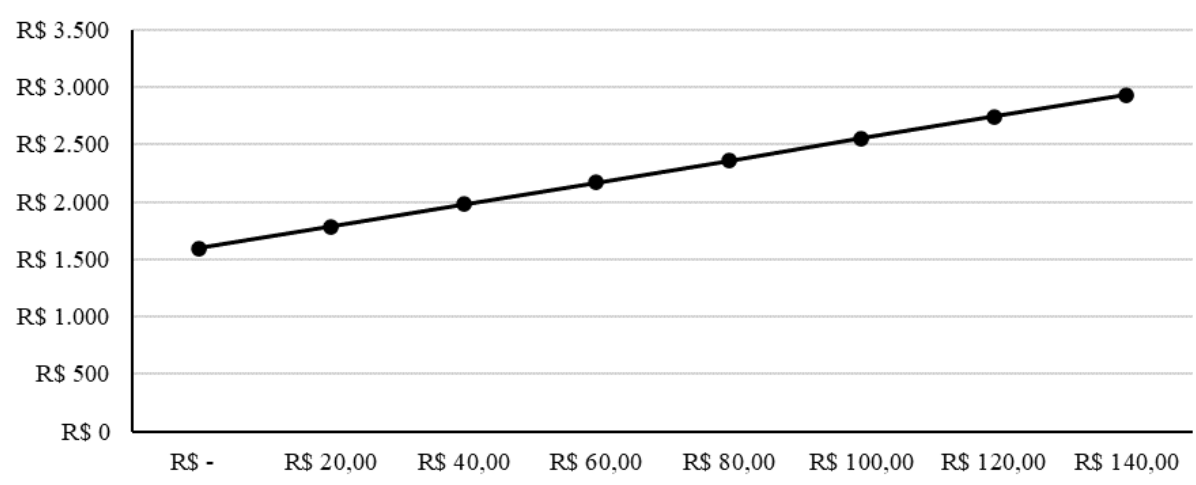

Figura 49: Valor Presente do Projeto Hidrelétrico sem Flexibilidade para Diferentes Valores de Lastro Fonte: Autora

Posteriormente, observaram-se então as condições de realização do investimento, quando são consideradas como variáveis estocásticas a geração hidrelétrica e o preço da energia. Através da simulação, calculou-se a volatilidade do retorno dos fluxos de caixa do projeto. Assim como já era esperado, conforme se aumenta o valor do contrato de Lastro adquirido pela usina hidrelétrica no mercado regulado, reduz-se a volatilidade dos fluxos de caixa do projeto. A volatilidade do retorno do projeto observada para os diferentes valores de Lastro da usina hidrelétrica está descrita na Figura a seguir.

Uma vez tendo as volatilidades calculadas, pode-se estimar qual é o valor da opção de espera de realizar o investimento em até 4 anos. Pode-se observar que a opção de espera tem valor até o valor de Lastro próximo aos $\mathrm{R} \$ 100 / \mathrm{MWh}$. A partir deste preço, não faz mais sentido para o investidor esperar para realizar o investimento, pois não estará mais renunciando a nenhum custo de oportunidade no presente. 
Volatilidade do Retorno do Projeto Hidrelétrico para

Diferentes Valores de Lastro (\%)

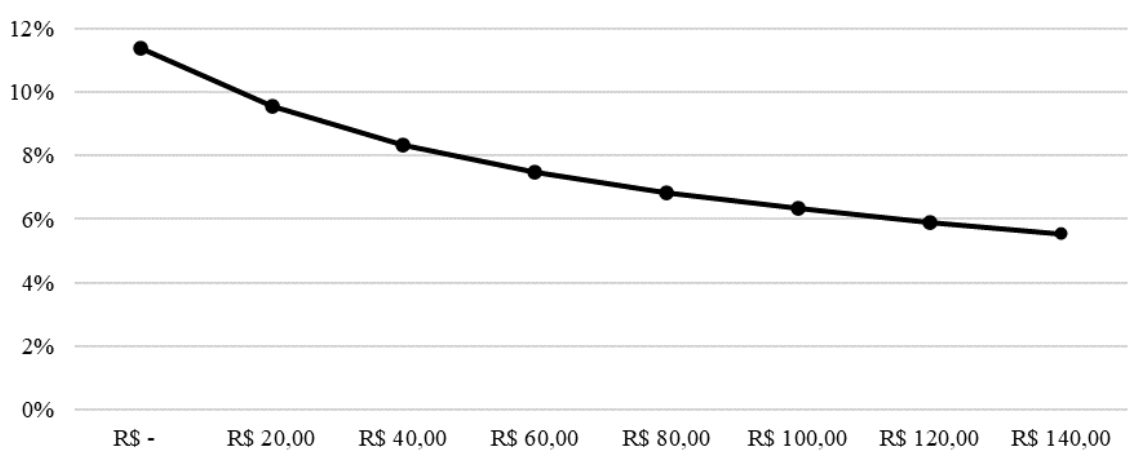

Figura 50: Volatilidade da Taxa de Retorno do Projeto Hidrelétrico para diferentes valores de Lastro Fonte: Autora

Valo Presente Líquido e Opção de Espera do Projeto Hidrelétrico

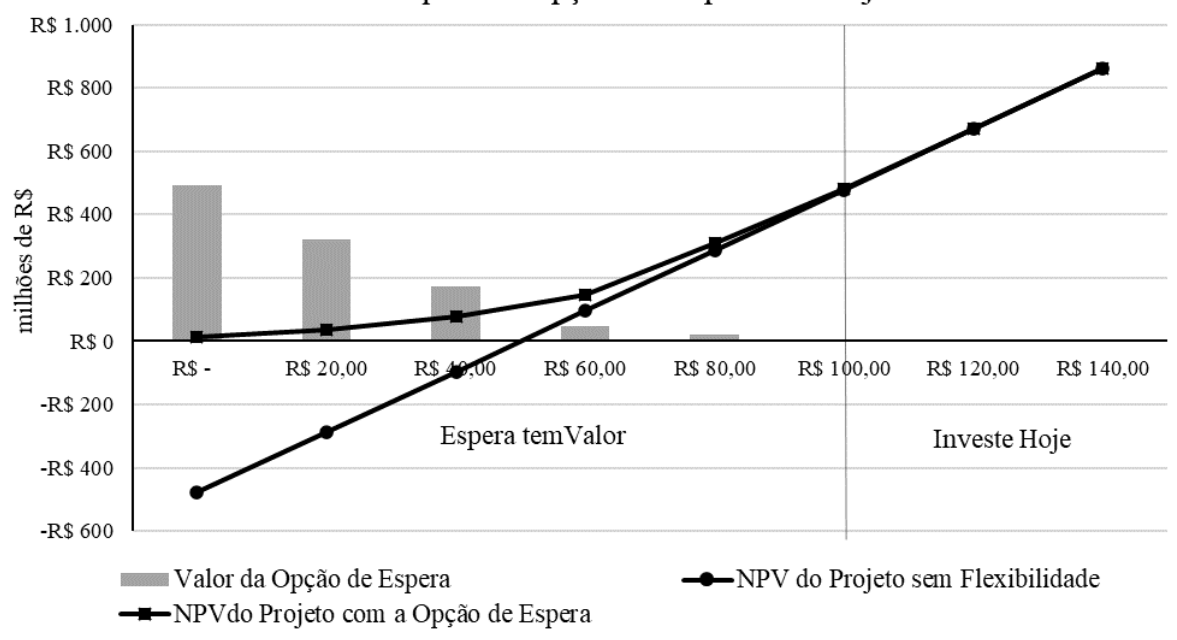

Figura 51: Valor Presente do Projeto com a Opção de Espera para Diferentes Valores de Lastro

Fonte: Autora

Os diagramas binomiais que se seguem, ilustram como a realização dos investimentos no projeto hidrelétrico se comporta no período de análise, conforme se varia o valor do Lastro. Pode-se observar que, conforme o valor do Lastro aumenta, a decisão de investimento nas árvores aumenta, assim como a atratividade do investimento (maior VPL). Além disso, pode-se observar também que, conforme o valor do Lastro aumenta, o VPL com a opção de esperar tende a se igualar ao VPL estático. 
Árvore Binomial quando Lastro $=0 \mathrm{R} \$ / \mathrm{MWh}$

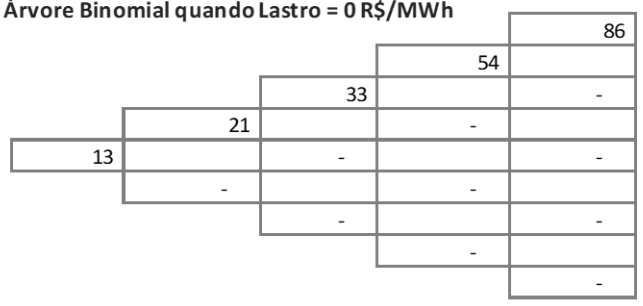

2019

202

2022

Árvore Binomial quando Lastro $=40 \mathrm{R} \$ \mathrm{MWh}$

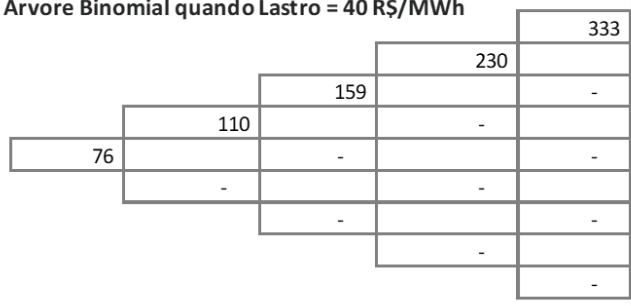

2019

2020

2021

2022

2023

Árvore Binomial quando Lastro $=80 \mathrm{R} \$ / \mathrm{MWh}$

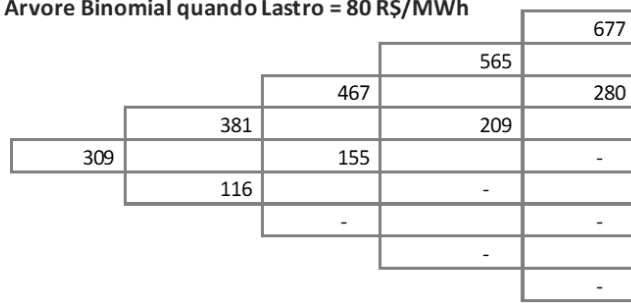

$\begin{array}{lllll}2019 & 2020 & 2021 & 2022 & 2023\end{array}$

Árvore Binomial quando Lastro $=120 \mathrm{R} \$ / \mathrm{MWh}$

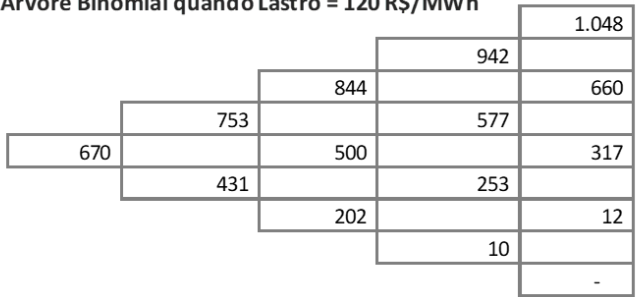

2019

2021

2022

2023

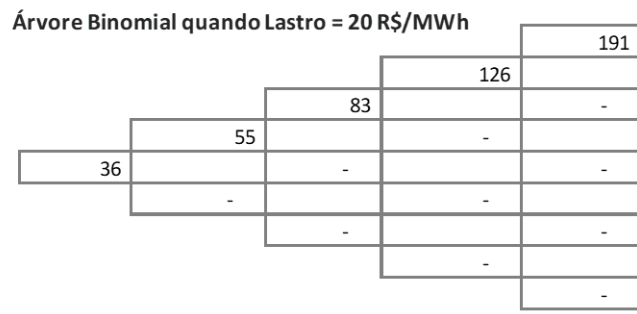

$\begin{array}{lllll}2019 & 2020 & 2021 & 2022 & 2023\end{array}$

Árvore Binomial quando Lastro $=60 \mathrm{R} \$ \mathrm{MWh}$

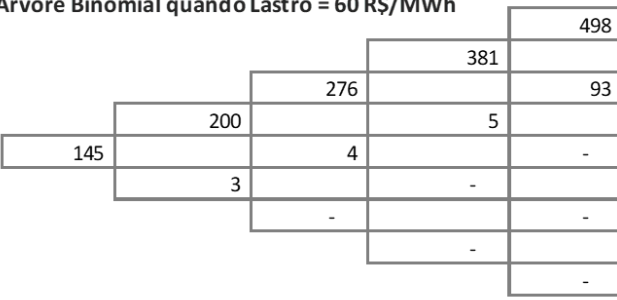

$\begin{array}{llll}2019 & 2020 & 2021 & 2022\end{array}$

2023

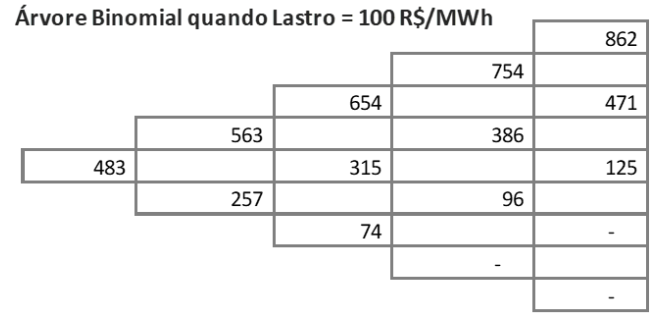

2019

2020

2021

2022

2023

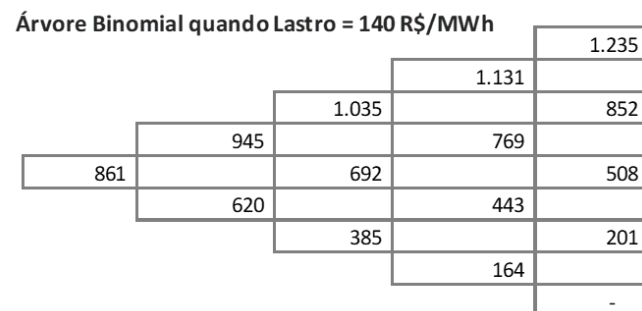

2019

2021

2022

2023

Figura 52: Árvores Binomiais da Opção de Espera para o Investimento no Projeto Hidrelétrico Considerando Diferentes Valores de Lastro

Fonte: Autora

Uma próxima análise procurou avaliar qual o impacto do Valor da Opção de Espera quando se tem diferentes prazos de espera para realizar o investimento. A análise foi feita para o período de 3 anos de espera em escala de decisão anual, 2 anos de espera em escala de decisão semestral e 1 ano de espera com escala de decisão trimestral. $\mathrm{O}$ gráfico a seguir ilustra os valores obtidos. 
Valo Presente Líquido do Projeto Hidrelétrico para Diferentes Prazos de Espera

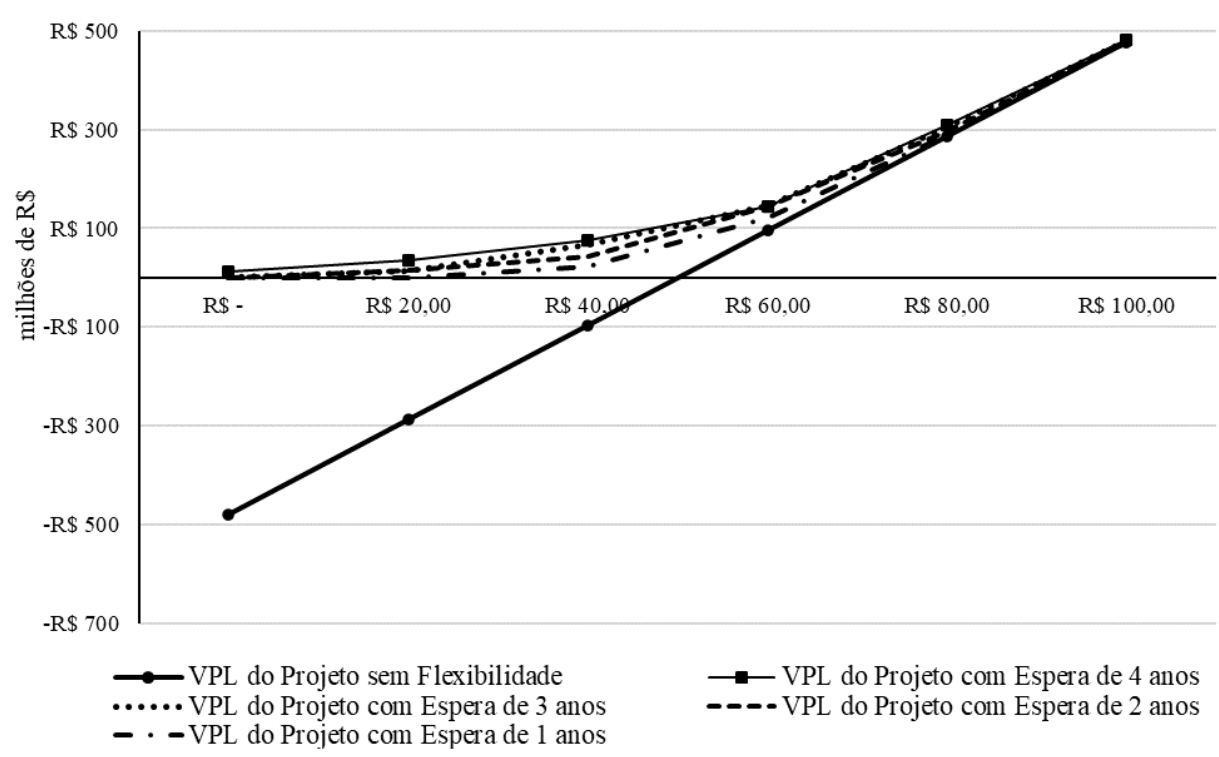

Figura 53: Valor Presente Líquido do Projeto Hidrelétrico para Diferentes Prazos de Espera

Fonte: Autora

Como pode-se observar dos resultados obtidos, o Preço crítico do Lastro para a realização do investimento continua no entorno dos $\mathrm{R} \$ 100 / \mathrm{MWh}$ para qualquer prazo de espera. Além disso, observa-se também que a redução do prazo de espera acaba por diminuir o valor da opção, ou seja, do custo de oportunidade, contudo, sem alterar substancialmente os resultados obtidos. Para os valores de Lastro mais baixos, entre zero e R\$20/MWh, observou-se que não seria viável investir no projeto a depender do tempo de espera, conforme ilustra a próxima tabela.

Tabela 14: Valor Presente Líquido do Projeto com Opção de Espera em Diferentes Períodos

\begin{tabular}{|c|c|c|c|c|c|c|c|c|c|}
\hline \multicolumn{2}{|c|}{$\begin{array}{c}\text { Valor do Lastro } \\
\text { Hidrelétrico } \\
\text { (R\$/MWh) }\end{array}$} & \multicolumn{2}{|c|}{$\begin{array}{c}\text { VPL do Projeto } \\
\text { com Espera de } 4 \\
\text { Anos (milhões) }\end{array}$} & \multirow{2}{*}{\multicolumn{2}{|c|}{$\begin{array}{c}\text { VPL do Projeto } \\
\text { com Espera de } 3 \\
\text { Anos (milhões) }\end{array}$}} & \multirow{2}{*}{\multicolumn{2}{|c|}{$\begin{array}{c}\text { VPL do Projeto } \\
\text { com Espera de } 2 \\
\text { Anos (milhões) }\end{array}$}} & \multirow{2}{*}{\multicolumn{2}{|c|}{$\begin{array}{c}\text { VPL do Projeto } \\
\text { com Espera de } 1 \\
\text { Ano (milhões) } \\
\text { Não Investir }\end{array}$}} \\
\hline $\mathbf{R} \$$ & - & $\mathrm{R} \$$ & 13 & & & & & & \\
\hline $\mathbf{R} \$$ & 20 & $\mathrm{R} \$$ & 36 & $\mathrm{R} \$$ & 13 & $\mathrm{R} \$$ & 14 & & \\
\hline $\mathbf{R} \$$ & 40 & $\mathrm{R} \$$ & 76 & $\mathrm{R} \$$ & 68 & $\mathrm{R} \$$ & 44 & $\mathrm{R} \$$ & 25 \\
\hline $\mathbf{R} \$$ & 60 & $\mathrm{R} \$$ & 145 & $\mathrm{R} \$$ & 145 & $\mathrm{R} \$$ & 145 & $\mathrm{R} \$$ & 120 \\
\hline $\mathbf{R} \$$ & 80 & $\mathrm{R} \$$ & 309 & $\mathrm{R} \$$ & 305 & $\mathrm{R} \$$ & 297 & $\mathrm{R} \$$ & 289 \\
\hline $\mathbf{R} \$$ & 100 & $\mathrm{R} \$$ & 483 & $\mathrm{R} \$$ & 480 & $\mathrm{R} \$$ & 478 & $\mathrm{R} \$$ & 478 \\
\hline $\mathbf{R} \$$ & 120 & $\mathrm{R} \$$ & 670 & $\mathrm{R} \$$ & 670 & $\mathrm{R} \$$ & 670 & $\mathrm{R} \$$ & 670 \\
\hline $\mathbf{R} \$$ & 140 & $\mathrm{R} \$$ & 861 & $\mathrm{R} \$$ & 861 & $\mathrm{R} \$$ & 861 & $\mathrm{R} \$$ & 861 \\
\hline
\end{tabular}

Fonte:Autora 
Foi feita também uma análise com cenários estressados de preço para avaliar qual o impacto que uma conjuntura mais 'estressada' do sistema elétrico brasileiro teria sobre o preço requerido do Lastro hidrelétrico para o investimento hoje e sobre o preço das Opções de Espera. A simulação foi realizada então com o cenário hidrológico do final do ano de 2014, quando o Brasil passou um período de preços de energia elevados associados a uma hidrologia ruim. Primeiramente foram recalculados os valores de volatilidade para os novos cenários apresentados e então, posteriormente, os valores de Valor Presente Líquido com a Opção de Espera do projeto.

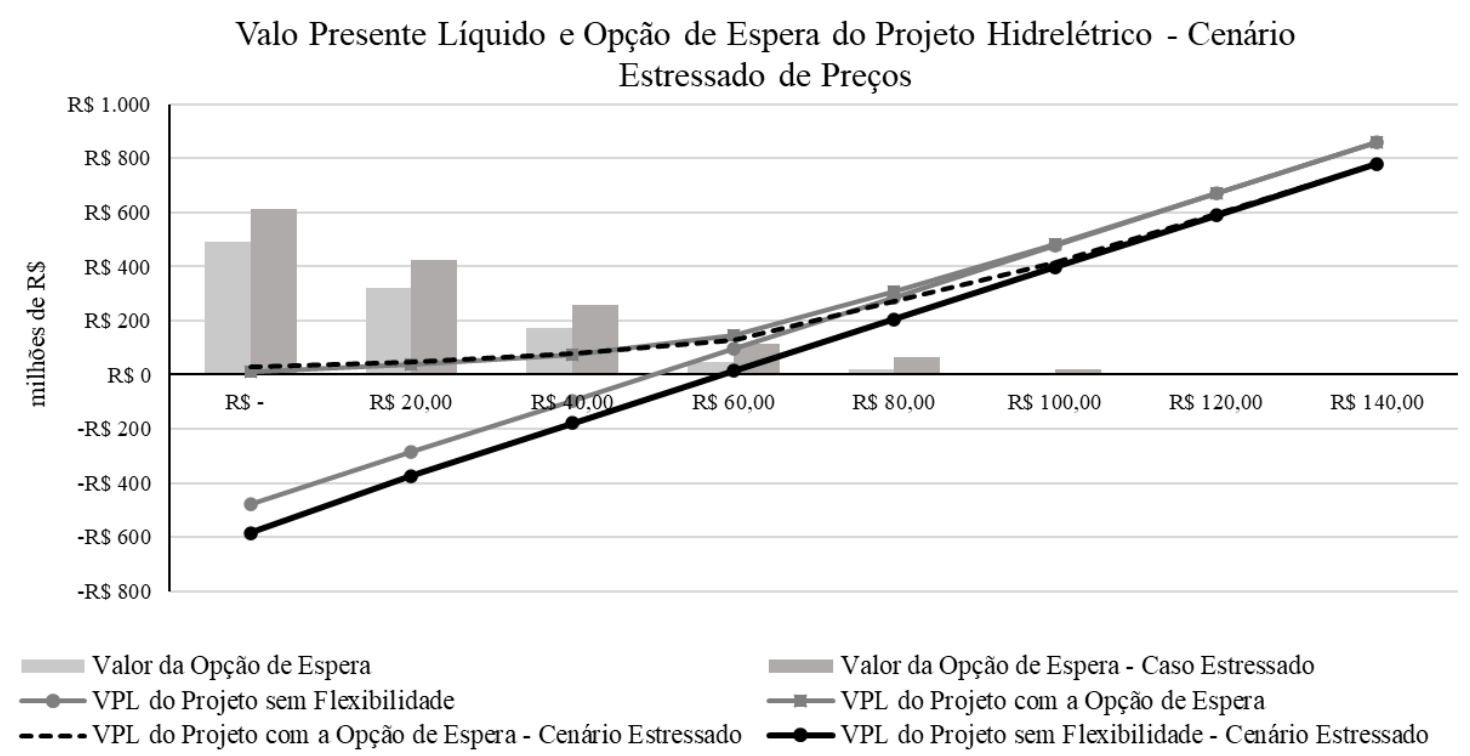

Figura 54: Valor Presente do Projeto com a Opção de Espera para Diferentes Valores de Lastro - Caso com Preços Estressados

Fonte: Autora

Como se pode observar, o valor do projeto como um todo foi reduzido, tanto no caso estático, quanto no caso em que há a possibilidade de esperar, uma vez que os cenários de preço e hidrologia eram menos favoráveis que no caso base. Com relação ao valor das opções de espera, pode observar também um aumento dos valores obtidos com relação ao caso base para todas as faixas de Lastro hidrelétrico. Com relação ao preço do Lastro a partir do qual o investimento pode ocorrer hoje, sem que haja custo de oportunidade envolvido, este passou dos $\mathrm{R} \$ 100 / \mathrm{MWh}$ no caso base para $\mathrm{R} \$ 120 / \mathrm{MWh}$. 


\subsubsection{Análise de Investimento em uma Hidrelétrica e uma Eólica Quando a} Eólica Não Comercializa Lastro

O segundo estudo de caso a ser realizado analisa o investimento em uma usina hidrelétrica e em um parque eólico, quando há a opção de adiar o investimento por um período de até quatro anos. O objetivo aqui é observar o benefício que o investimento em conjunto entre as fontes hidrelétrica e eólica traz para o valor do investimento realizado. Neste estudo de caso, tem-se como variáveis estocásticas a produção hidrelétrica do SIN, o regime de ventos e o preço da energia. Conforme o ilustra o gráfico a seguir, onde se tem o comportamento do GSF e do regime de ventos utilizado, pode-se observar a complementariedade entre as variáveis.

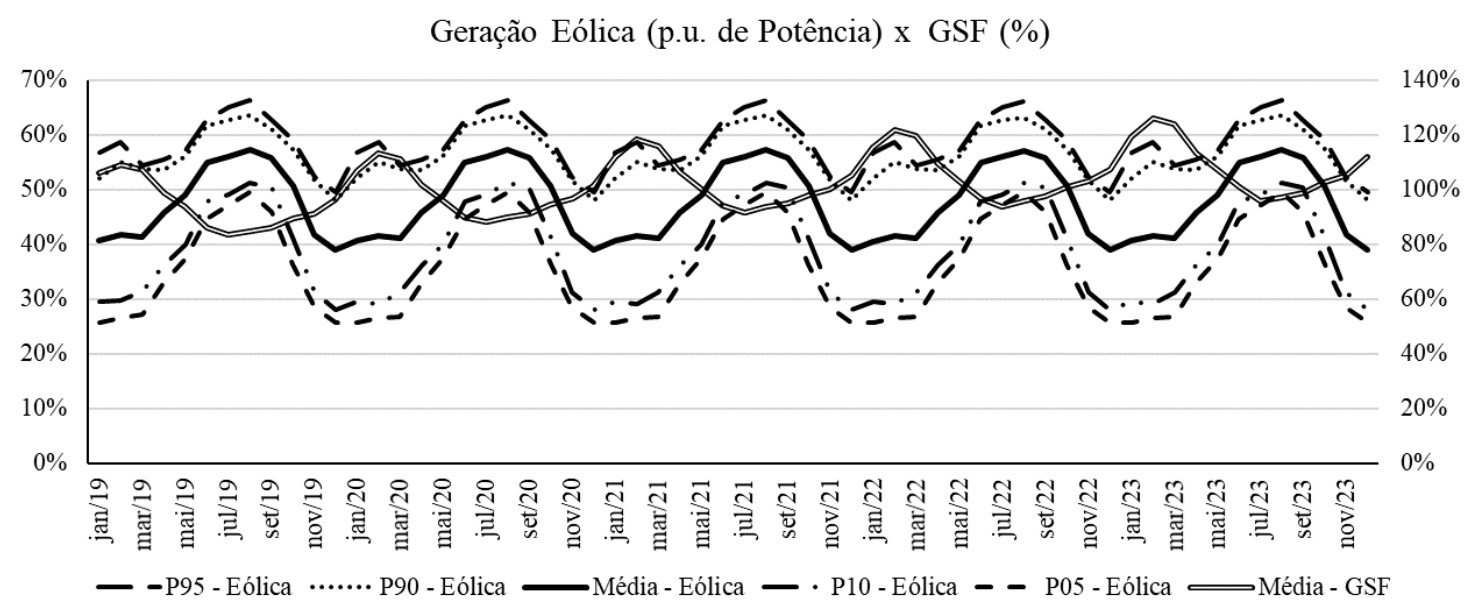

Figura: Geração Eólica versus o GSF no Estudo de Caso

Fonte: Autora

A usina hidrelétrica considerada na análise é a mesma do primeiro estudo de caso, e sua venda de energia também vai ter o Lastro variando de zero a R \$140/MWh. Já para a usina eólica, considerou-se uma planta de 100MW de potência, com 45MWmédios de garantia física, localizada em Macau no interior da Rio Grande do Norte. As premissas de investimento e operação e manutenção são as mesmas que as adotadas na seção onde se calcula o valor do Preço Teto do Lastro. O valor do investimento realizado é R $\$ 460,8$ milhões de reais. Realizou-se o cálculo do valor da Opção de Espera no investimento eólico sozinho, sem comercializar Lastro, para o mesmo período de espera de investimento conjunto, chegando-se no valor de $\mathrm{R} \$ 79$ milhões. 
Num primeiro momento, observa-se os benefícios da combinação hidro-eólica, quando a planta eólica comercializa contratos por quantidade no mercado livre, sem qualquer comercialização de Lastro.

Foi calculado o Valor Presente do projeto, variando os valores do Lastro da hidrelétrica de zero a $\mathrm{R} \$ 140 / \mathrm{MWh}$, mantendo as variáveis estáticas, sendo esse o caso base, ou seja, quando não há nenhuma flexibilidade. Os valores presentes do projeto são ilustrados no gráfico a seguir.

Valor Presente do Projeto Hidro-eólico sem Flexibilidade para Diferentes Valores de Lastro da Hidrelétrica ( $\mathrm{mn} \mathrm{R} \$$ )

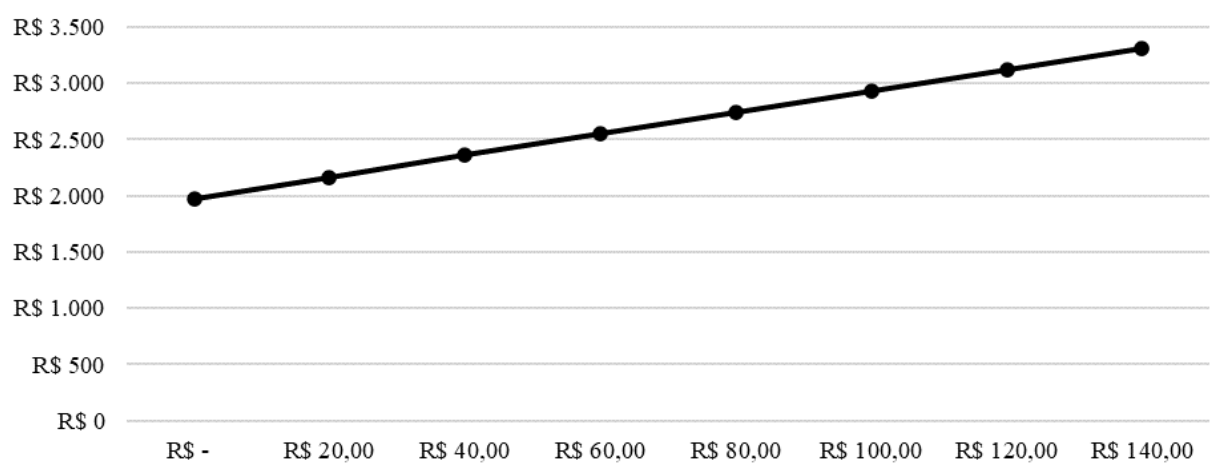

Figura 55: Valor Presente do Projeto Hidro-eólico sem Flexibilidade para Diferentes Valores de Lastro da Usina Hidrelétrica

Fonte: Autora

Posteriormente, observaram-se então as condições de realização do investimento quando são consideradas como variáveis estocásticas a geração hidrelétrica, a geração eólica e o preço da energia. Através da simulação, calculou-se a volatilidade do retorno dos fluxos de caixa do projeto. Assim, como já era esperado, conforme se aumenta o valor do contrato de Lastro adquirido pela usina hidrelétrica no mercado regulado, reduz-se substancialmente a volatilidade dos fluxos de caixa do projeto. As volatilidades do retorno do projeto observadas para os diferentes valores de Lastro da usina hidrelétrica estão apresentadas na figura que segue.

Uma vez tendo as volatilidades calculadas, pode-se estimar qual é o valor da opção de espera de realizar o investimento em até 4 anos. Pode-se observar que a opção de espera é diferente de zero até um valor de Lastro entre $\mathrm{R} \$ 100 / \mathrm{MWh}$ e $\mathrm{R} \$ 120 / \mathrm{MWh}$, ou seja o preço crítico do Lastro se encontra nessa faixa. Quando comparado com a hidrelétrica isoladamente, o valor da opção de espera em $\mathrm{R} \$ 100 / \mathrm{MWh}$ é de $\mathrm{R} \$ 14$ milhões de reais. 
Volatilidade do Retorno do Projeto Hidro-eólico para

Diferentes Valores de Lastro da Hidrelétrica (\%)

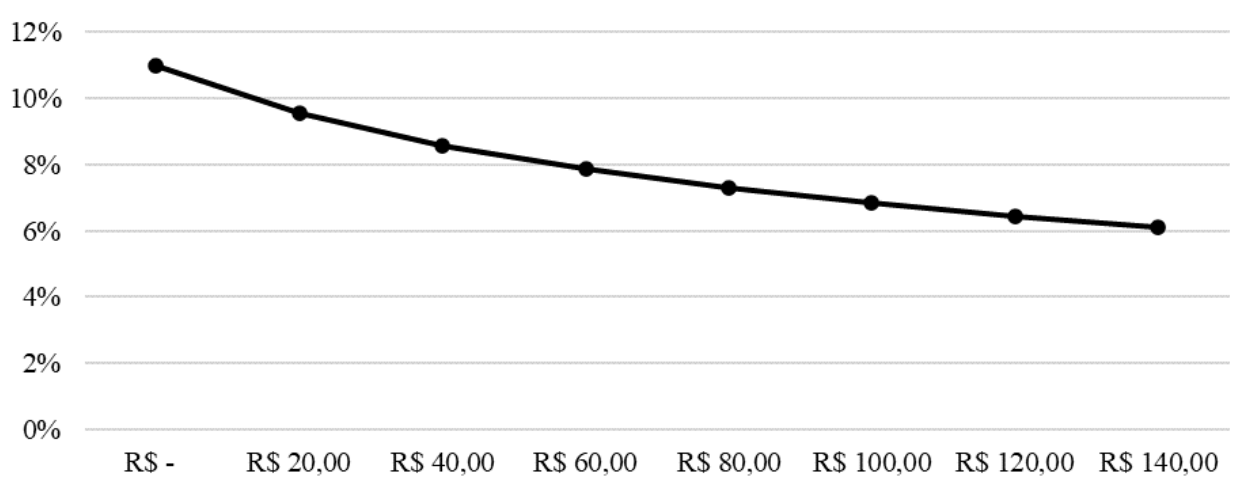

Figura 56: Volatilidade da Taxa de Retorno do Projeto Hidro-eólico para diferentes valores de Lastro da Usina Hidrelétrica

Fonte: Autora

Cabe lembrar que, partir do momento em que a opção de espera é zerada, não faz mais sentido para o investidor esperar para realizar o investimento, pois não estará mais renunciando a nenhum custo de oportunidade no presente.

Valor Presente do Projeto Hidro-eólico com a Opção de Espera para Diferentes Valores de Lastro da Hidrelétrica $(\mathrm{mn} \mathrm{R} \$$ )

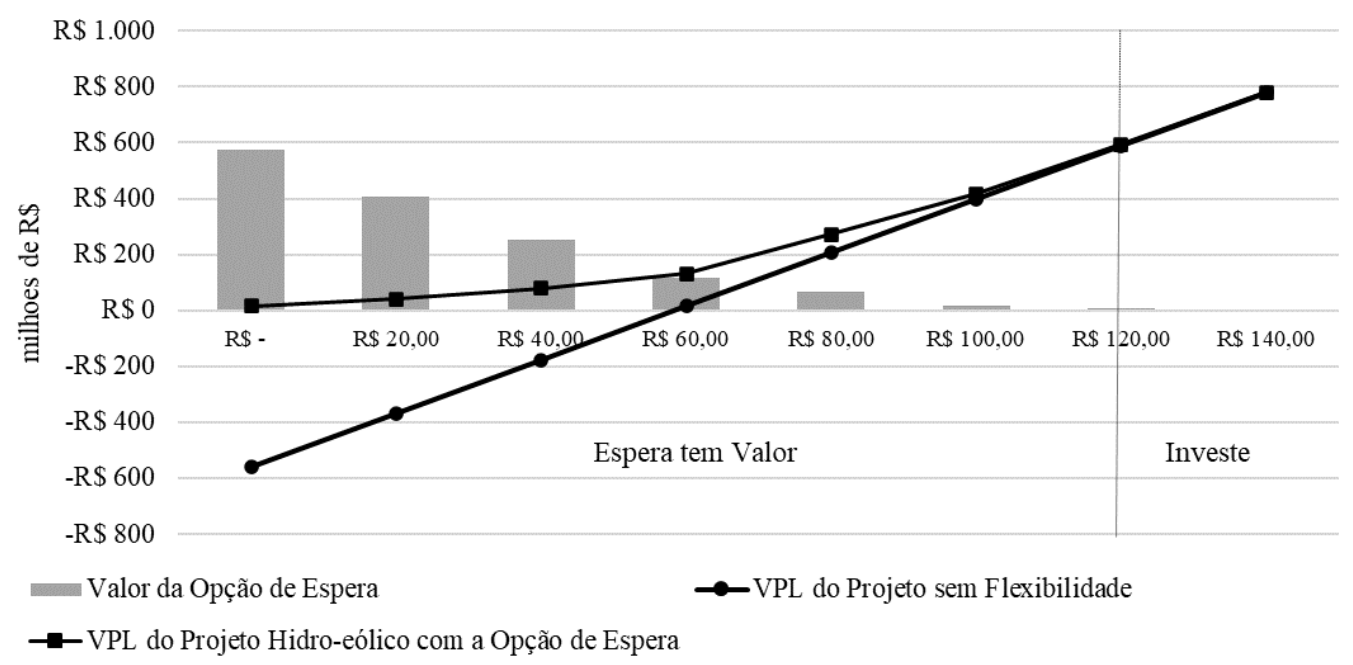

Figura 57: Valor Presente do Projeto Hidro-eólico com a Opção de Espera para Diferentes Valores de Lastro da Usina Hidrelétrica

Fonte: Autora

Daqui pode-se entender que, apesar do investimento adicional no parque eólico e da variabilidade do vento ser incluída no processo de precificação, o conjunto do projeto Hidro-eólico se mostra viável para investir, hoje, a partir de uma faixa de preço de Lastro hidrelétrico próxima ao projeto hidrelétrico isoladamente, mesmo quando a usina eólica não comercializa Lastro. 
Os diagramas binomiais a seguir ilustram como a realização dos investimentos no projeto hidrelétrico se comporta no período de análise, conforme se varia o valor do Lastro. Pode-se observar que conforme o valor do Lastro aumenta, a decisão de investimento nas árvores aumenta, assim como a atratividade do investimento (maior VPL). Portanto, conforme maior o valor do Lastro para a hidrelétrica, maior é o custo de oportunidade de investir agora.

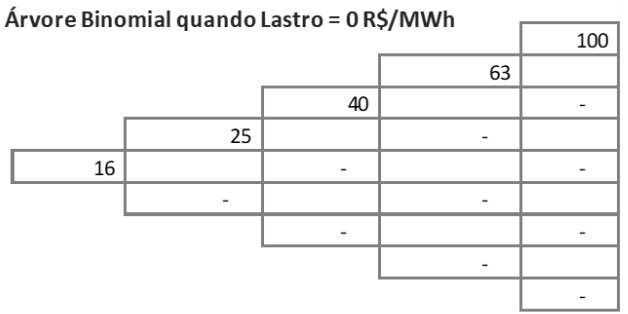

2019

2023

Árvore Binomial quando Lastro $=40 \mathrm{R} \$ / \mathrm{MWh}$

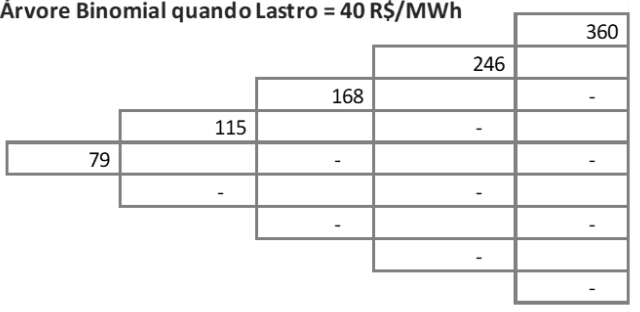

2019

2020

2021

2022

Árvore Binomial quando Lastro $=80 \mathrm{R} \$ / \mathrm{MWh}$

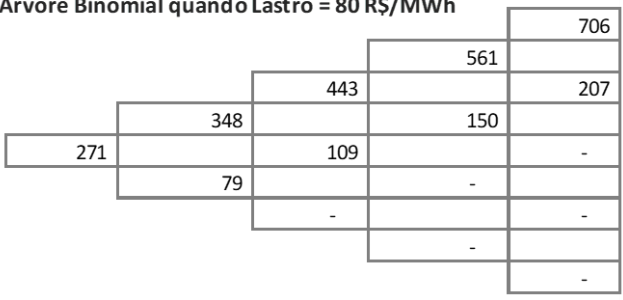

2019

2020

Árvore Binomial quando Lastro $=120 \mathrm{RS} / \mathrm{MWh}$

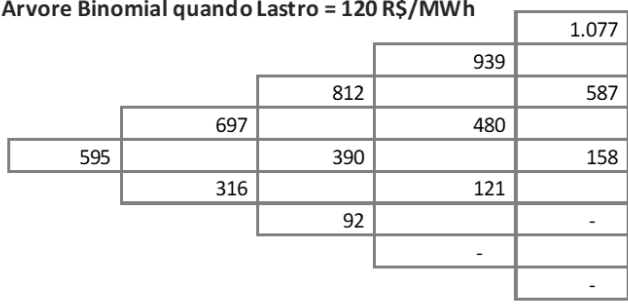

2019
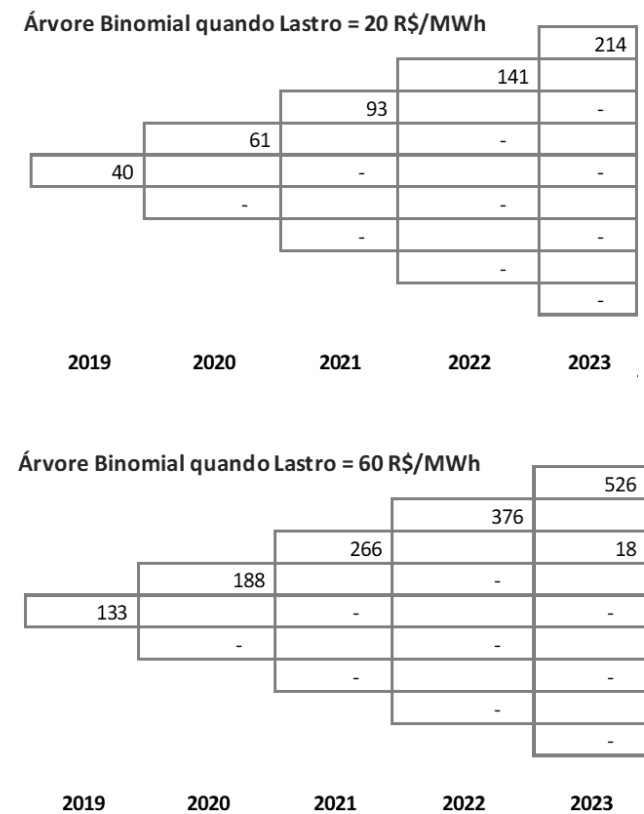

Árvore Binomial quand o Lastro $=100 \mathrm{R} \$ / \mathrm{MWh}$

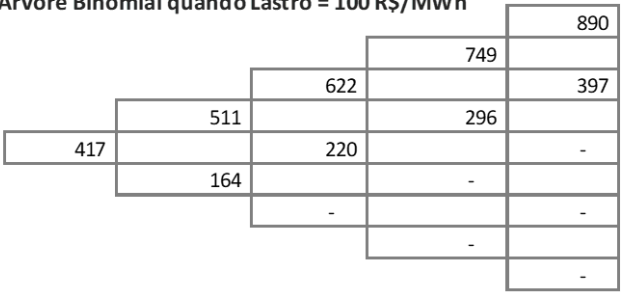

2019

2020

2021

2022

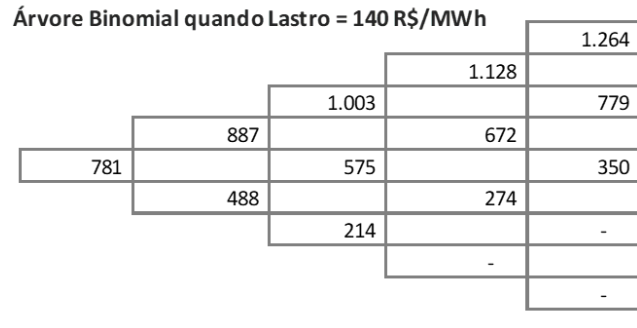

2019

Figura 58: Árvores Binomiais da Opção de Espera para o Investimento no Projeto Hidro-eólica Considerando Diferentes Valores de Lastro da Usina Hidrelétrica

Fonte: Autora 
Uma próxima análise procurou avaliar qual o impacto do Valor da Opção de Espera quando se tem diferentes prazos de espera para realizar o investimento. A análise foi feita para o período de 3 anos de espera em escala de decisão anual, 2 anos de espera em escala de decisão semestral e 1 ano de espera com escala de decisão trimestral. $\mathrm{O}$ gráfico a seguir ilustra os valores obtidos.

Valor Presente Líquido do Projeto Hidro-eólico para Diferentes Prazos de Espera

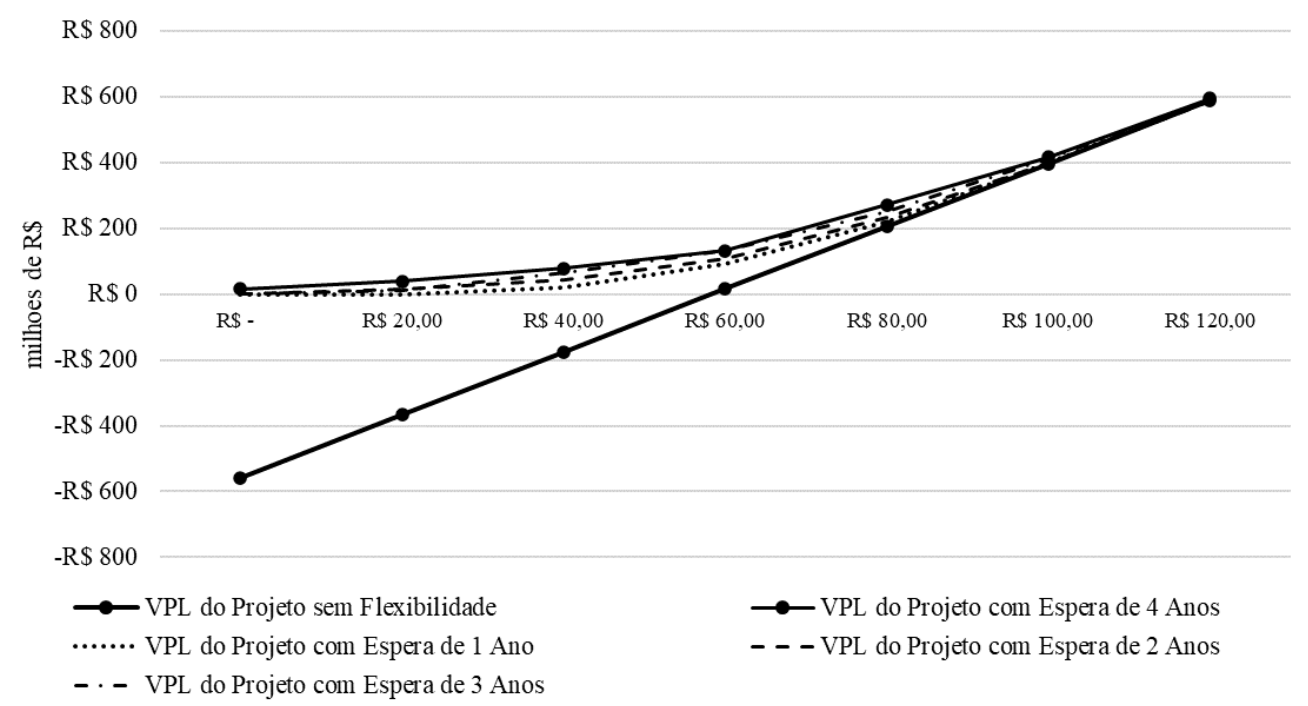

Figura 59: Valor Presente Líquido do Projeto Hidro-eólico para Diferentes Prazos de Espera

Fonte: Autora

Como pode-se observar dos resultados obtidos, o Preço crítico do Lastro para a realização do investimento continua entre $\mathrm{R} \$ 100 / \mathrm{MWh}$ e $\mathrm{R} \$ 120 / \mathrm{MWh}$ para qualquer prazo de espera. Além disso, observa-se também que a redução do prazo de espera acaba por diminuir o valor da opção, ou seja, do custo de oportunidade, contudo, sem alterar substancialmente os resultados obtidos. Para os valores de Lastro mais baixos, entre zero e R\$20/MWh, observou-se que não seria viável investir no projeto a depender do tempo de espera, conforme ilustra a tabela que se segue.

O gráfico da figura logo em seguida, compara o custo de oportunidade do investimento em conjunto com os investimentos em separado. A partir do valor de Lastro hidrelétrico de R\$60/MWh, já se começa a observar que o custo de oportunidade do investimento em conjunto (projeto Hidro-eólico) é maior do que quando o investimento é realizado nas plantas em separado. 
Tabela 15: Valor Presente Líquido do Projeto com Opção de Espera em Diferentes Períodos.

\begin{tabular}{|c|c|c|c|c|}
\hline $\begin{array}{c}\text { Valor do Lastro } \\
\text { Hidrelétrico } \\
\text { (R\$/MWh) }\end{array}$ & $\begin{array}{c}\text { VPL do Projeto } \\
\text { com Espera de 4 } \\
\text { Anos (milhões) }\end{array}$ & $\begin{array}{c}\text { VPL do Projeto } \\
\text { com Espera de 3 } \\
\text { Anos (milhões) }\end{array}$ & $\begin{array}{c}\text { VPL do Projeto } \\
\text { com Espera de 2 } \\
\text { Anos (milhões) }\end{array}$ & $\begin{array}{c}\text { VPL do Projeto } \\
\text { com Espera de 1 } \\
\text { Ano (milhões) }\end{array}$ \\
\hline R\$ - & $\mathrm{R} \$ 16$ & Não Investir & Não Investir & Não Investir \\
\hline $\mathbf{R} \$ \mathbf{2 0}$ & $\mathrm{R} \$ 40$ & $\mathrm{R} \$ 11$ & $\mathrm{R} \$ 15$ & Não Investir \\
\hline $\mathbf{R} \$ \mathbf{4 0}$ & $\mathrm{R} \$ 79$ & $\mathrm{R} \$ 64$ & $\mathrm{R} \$ 43$ & $\mathrm{R} \$ 21$ \\
\hline $\mathbf{R} \$ \mathbf{6 0}$ & $\mathrm{R} \$ 133$ & $\mathrm{R} \$ 133$ & $\mathrm{R} \$ 107$ & $\mathrm{R} \$ 90$ \\
\hline $\mathbf{R} \$ \mathbf{8 0}$ & $\mathrm{R} \$ 271$ & $\mathrm{R} \$ 252$ & $\mathrm{R} \$ 235$ & $\mathrm{R} \$ 223$ \\
\hline $\mathbf{R} \$ \mathbf{1 0 0}$ & $\mathrm{R} \$ 417$ & $\mathrm{R} \$ 414$ & $\mathrm{R} \$ 398$ & $\mathrm{R} \$ 399$ \\
\hline $\mathbf{R} \$ \mathbf{1 2 0}$ & $\mathrm{R} \$ 595$ & $\mathrm{R} \$ 591$ & $\mathrm{R} \$ 590$ & $\mathrm{R} \$ 589$ \\
\hline $\mathbf{R} \$ \mathbf{1 4 0}$ & $\mathrm{R} \$ 781$ & $\mathrm{R} \$ 781$ & $\mathrm{R} \$ 781$ & $\mathrm{R} \$ 782$ \\
\hline
\end{tabular}

Fonte: Autora

Ganho no Custo de Oportunidade no Investimento em Conjunto no Projeto Hidro-eólico

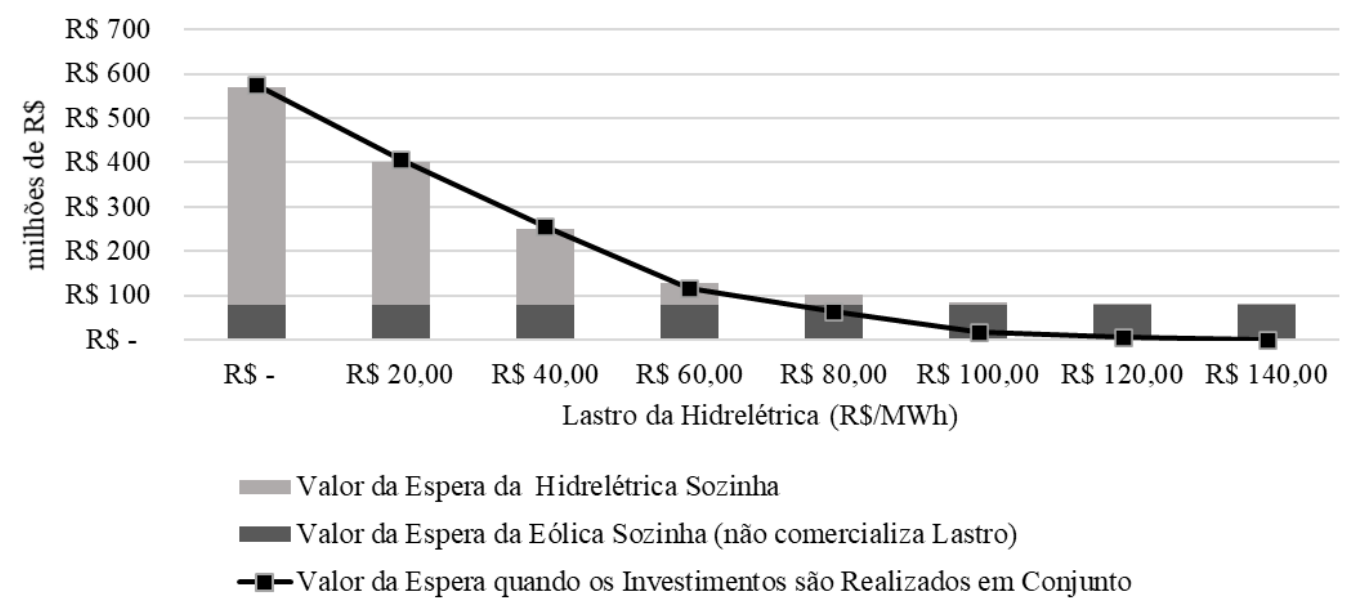

Figura 60: Ganho do Custo de Oportunidade no Investimento em Conjunto no Projeto Hidro-eólico

Fonte: Autora

Foi feita também uma análise com cenários estressados de preço para avaliar qual o impacto que uma conjuntura mais 'estressada' do sistema elétrico brasileiro teria sobre o preço requerido do Lastro hidrelétrico para o investimento hoje e sobre o preço das Opções de Espera.

A simulação foi realizada então com o cenário hidrológico do final do ano de 2014, quando o Brasil passou um período de preços de energia elevados associados a uma hidrologia ruim. Primeiramente foram recalculados os valores de volatilidade para os novos cenários apresentados e então, posteriormente, os valores de Valor Presente Líquido com a Opção de Espera do projeto. 
Valor Presente do Projeto Hidro-eólico com a Opção de Espera para Diferentes Valores de Lastro da Hidrelétrica (mn R\$)

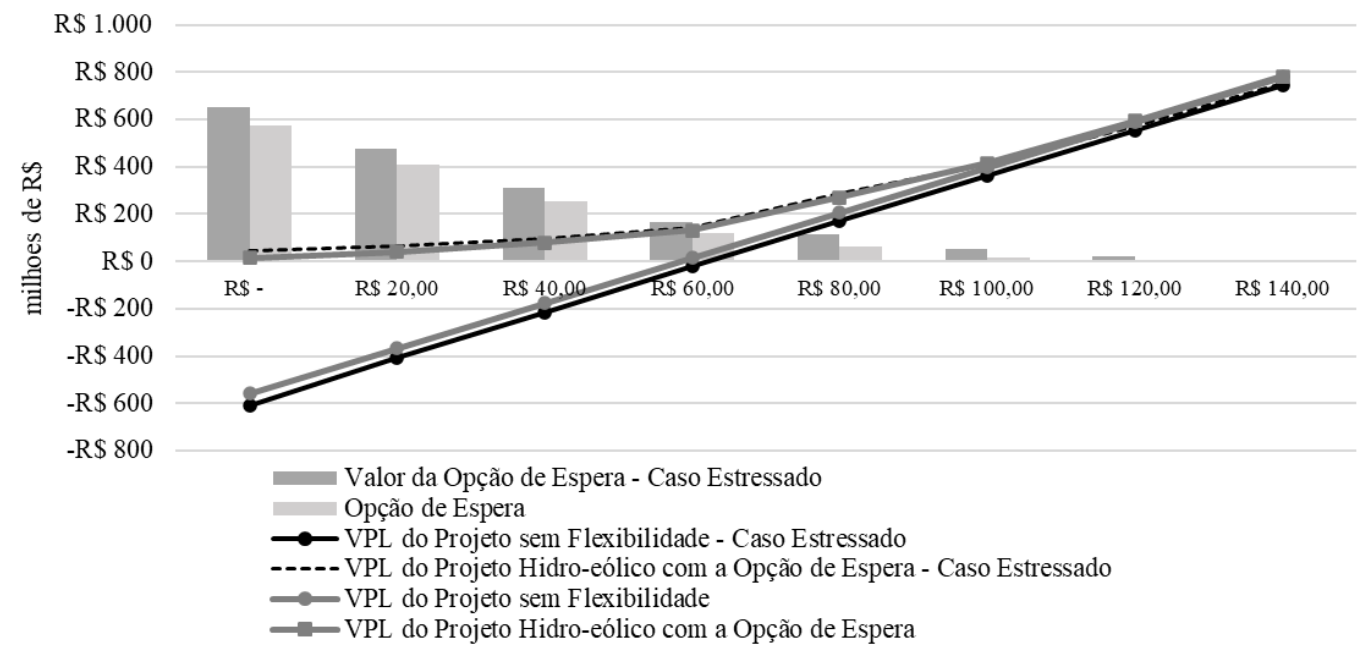

Figura 61: Valor Presente do Projeto com a Opção de Espera para Diferentes Valores de Lastro - Caso com Preços Estressados

Fonte: Autora

Como se pode observar, o valor do projeto no caso sem flexibilidade foi reduzido, contudo, em menor intensidade do que quando comparado com o caso da hidrelétrica sozinha. Com relação ao valor das opções de espera, pode-se observar um aumento dos valores obtidos com relação ao caso base para todas as faixas de Lastro hidrelétrico. Com relação ao preço do Lastro a partir do qual o investimento pode ocorrer hoje, sem que haja custo de oportunidade envolvido, este passou dos $\mathrm{R} \$ 120 / \mathrm{MWh}$ no caso base para $\mathrm{R} \$ 140 / \mathrm{MWh}$, todavia, mantendo os custos de oportunidades baixos nessa faixa de valores.

\subsubsection{Análise de Investimento em uma Hidrelétrica e uma Eólica Quando a Eólica Comercializa Lastro}

O terceiro estudo de caso a ser realizado objetiva analisar o investimento em uma usina hidrelétrica e em um parque eólico, quando há a opção de adiar o investimento por um período de até 4 anos, quando as plantas eólicas comercializam Lastro. Neste estudo de caso, tem-se como variáveis estocásticas a produção hidrelétrica do SIN, o regime de ventos e o preço da energia.

A usina hidrelétrica considerada na análise é a mesma do primeiro estudo de caso, e sua venda de energia também vai ter o Lastro variando de zero a $\mathrm{R} \$ 140 / \mathrm{MWh}$. Já para a usina eólica, é considerada uma planta de 100MW de potência, com 45MWmédios de garantia física, localizada em Macau no interior da Rio Grande do Norte. 
As premissas de investimento e operação e manutenção são as mesmas que as adotadas na seção onde se calcula o valor do Preço Teto do Lastro. O valor do investimento realizado é $\mathrm{R} \$ 460,8$ milhões de reais.

Num primeiro momento foi calculado o Valor Presente dos projetos, variando os valores do Lastro da hidrelétrica de zero a $\mathrm{R} \$ 140 / \mathrm{MWh}$ e variando o Lastro da eólica zero a $\mathrm{R} \$ 60 / \mathrm{MWh}$, mantendo as variáveis estocásticas estáticas, sendo esse o caso base, ou seja, quando não há nenhuma flexibilidade. Quando calculado o Valor Presente Líquido do projeto Hidro-eólico para o caso base, ou seja, quando não há flexibilidade, realizar-se-iam os investimentos apenas nos casos em que o valor do Lastro da Hidrelétrica está na faixa entre $\mathrm{R} \$ 40$ e $\mathrm{R} \$ 60 / \mathrm{MWh}$, conforme ilustra o gráfico a seguir.

Valor Presente do Projeto Hidro-eólico sem Flexibilidade para Diferentes Valores de Lastro Hidrelétrico e Eólico

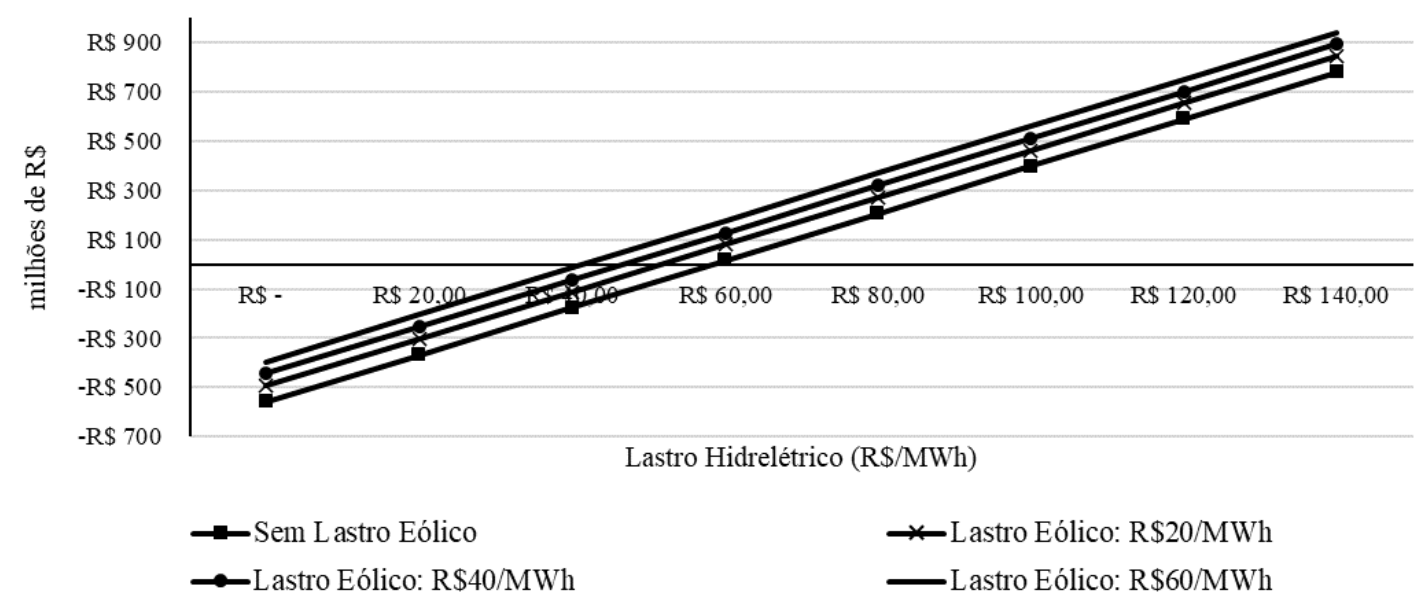

Figura 62: Valor Presente Líquido do Projeto Hidro-eólico sem Flexibilidade para Diferentes Valores de Lastro da Hidrelétrica e da Eólica

Fonte: Autora

Posteriormente, observou-se então as condições de realização do investimento quando são consideradas como variáveis estocásticas a geração hidrelétrica, a geração eólica e o preço da energia. Através da simulação, calculou-se a volatilidade do retorno dos fluxos de caixa do projeto. Assim, como já era esperado, conforme se aumenta o valor do contrato de Lastro adquirido pela usina hidrelétrica e da planta eólica no mercado regulado, reduz-se substancialmente a volatilidade dos fluxos de caixa do projeto.

Afigura-se interessante observar que a queda da volatilidade é mais acentuada nos cenários de Lastro mais baixo, estabilizando posteriormente na faixa entre 5\% a 7\% quando os Lastro comercializados são mais altos. 
A volatilidade do retorno do projeto observada para os diferentes valores de Lastro da usina hidrelétrica e da planta eólica estão descritas a seguir.

Comportamento da Volatlilidade para as Diferentes Combinações de Lastro no Complexo Hidro-Eólico

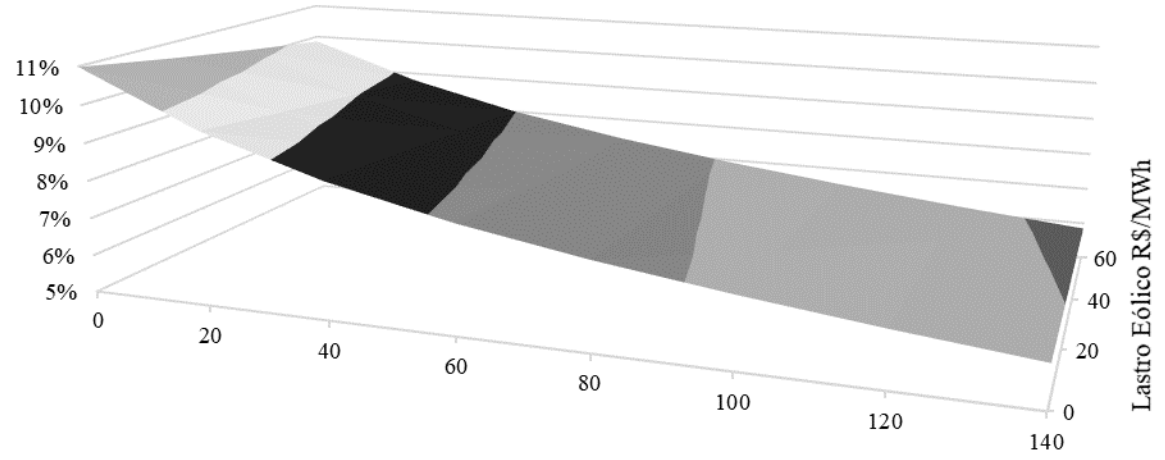

Lastro Hidrelétrico R \$MWh

$=5 \%-6 \% \quad \square 6 \%-7 \% \quad \square 7 \%-8 \% \quad \square 8 \%-9 \% \quad \square 9 \%-10 \% \quad \square 10 \%-11 \%$

Figura 63: Volatilidade do Retorno do Projeto Hidro-eólico para Diferentes Valores de Lastro da Hidrelétrica e da Eólica

Fonte: Autora

Uma vez tendo as volatilidades calculadas, pode-se estimar qual é o valor da opção de espera de realizar o investimento em até 4 anos. $O$ gráfico abaixo mostra os resultados obtidos de Valor Presente Líquido do Projeto Hidro-eólico para diferentes valores de Lastro contratado tanto para a Hidrelétrica quanto para a Eólica.

Comportamento do VPL com Flexibilidade para as Diferentes Combinações de Lastro no Complexo Hidro-Eólico

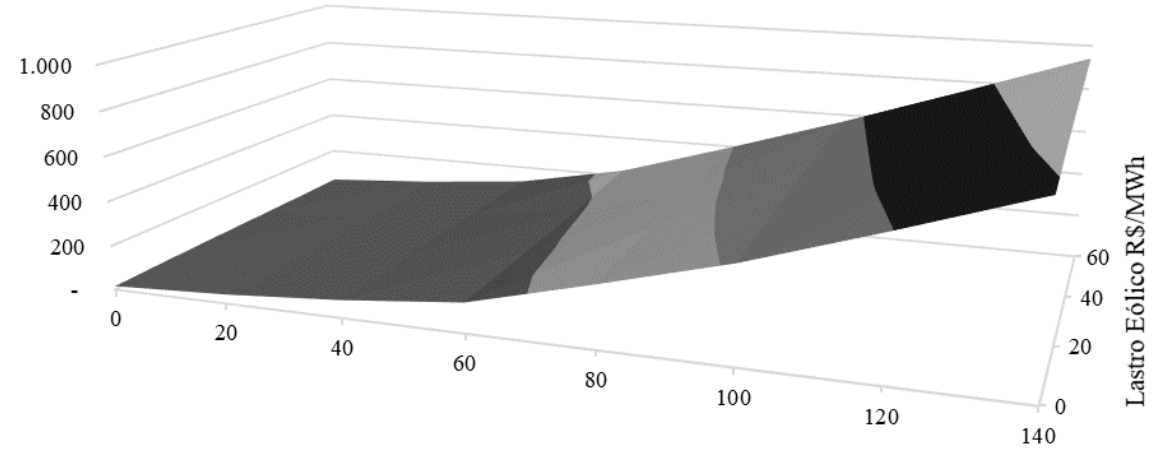

Lastro Hidrelétrico R \$MWh แ $-200=200-400 \square 400-600 \backsim 600-800=800-1.000$

Figura 64: Comportamento do Valor Presente Líquido com Flexibilidade do Projeto Hidro-eólico Fonte: Autora 
O gráfico a seguir mostra os valores da Opção de Espera para diferentes valores de Lastro Hidrelétrico e Eólico.

Comportamento da Opção de Espera para as Diferentes

Combinações de Lastro no Complexo Hidro-Eólico

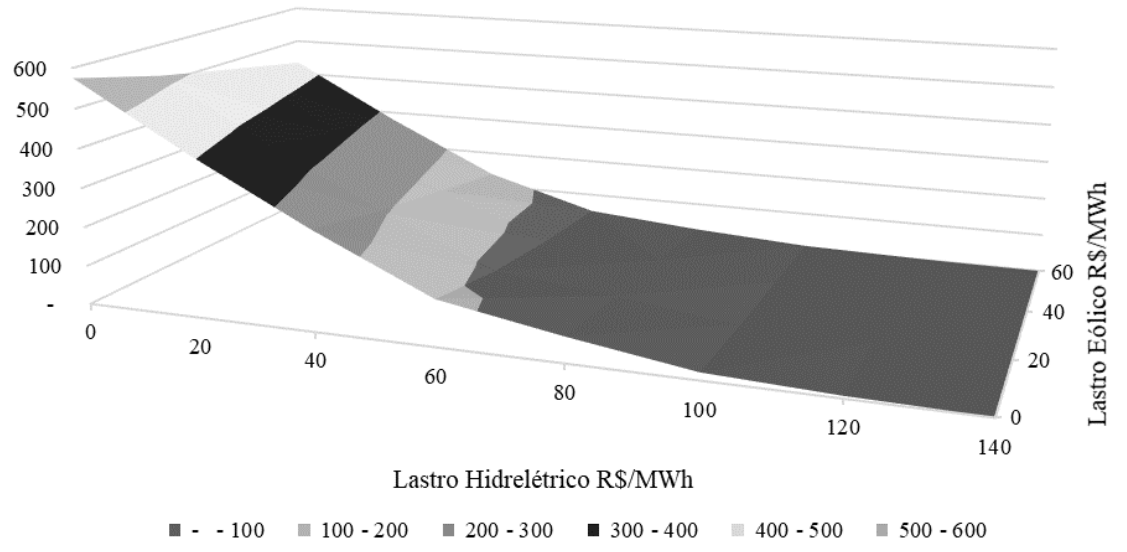

Figura 65: Comportamento da Opção de Espera do Projeto Hidro-eólico

Fonte: Autora

Do gráfico acima pode-se observar, pelo comportamento da Opção de Espera, que a na maior para das combinações o valor da opção fica baixo, próximo a zero ou mesmo zero, quando o valor do Lastro da planta hidrelétrica atinge valores entre $\mathrm{R} \$ 100 / \mathrm{MWh}$ e $\mathrm{R} \$ 140 / \mathrm{MWh}$. Portanto, é a partir de R \$100/MWh de Lastro hidrelétrico que fica mais atrativo para o investidor investir hoje mesmo no conjunto Hidro-eólico, a depender do valor de Lastro eólico comercializado.

Vale destacar que a contribuição do Lastro eólico para a redução do valor da opção de espera não é constante. Por exemplo, quando a hidrelétrica não comercializa Lastro, a comercialização de Lastro eólico reduz em até $25 \%$ o custo de oportunidade do investimento, já quando o Lastro hidrelétrico é de $\mathrm{R} \$ 60 / \mathrm{MWh}$, a redução do custo de oportunidade pela comercialização do Lastro eólico chega ser de quase $60 \%$.

Foi feita também uma análise com cenários estressados de preço para avaliar qual o impacto que uma conjuntura mais 'estressada' do sistema elétrico brasileiro teria sobre o preço requerido do Lastro hidrelétrico para o investimento hoje e sobre o preço das Opções de Espera. A simulação foi realizada então com o cenário hidrológico do final do ano de 2014, quando o Brasil passou um período de preços de energia elevados associados a uma hidrologia ruim. 
Primeiramente foram recalculados os valores de volatilidade para os novos cenários apresentados e então, posteriormente, os valores de Valor Presente Líquido com a Opção de Espera do projeto.

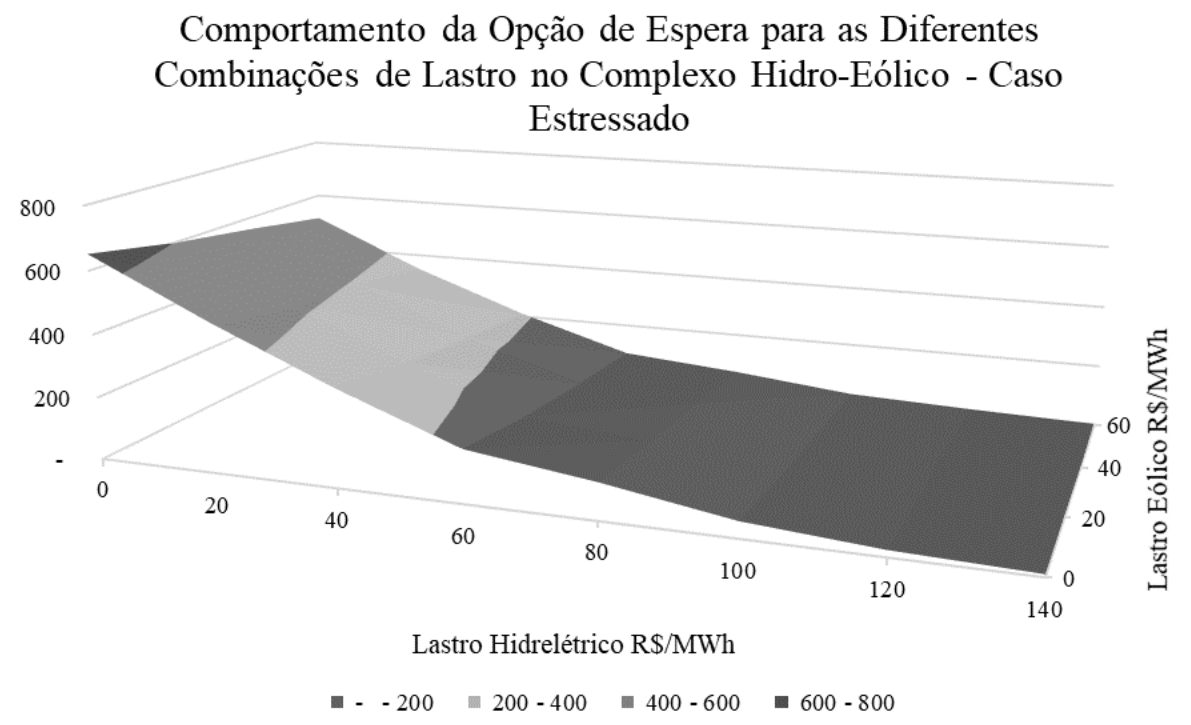

Figura 66: Comportamento da Opção de Espera do Projeto Hidro-eólico no Caso Estressado Fonte: Autora

Assim como nos estudos de caso anteriores, o cenário mais estressado de preços e hidrologia proporcionou um aumento nos valores das opções de espera em todos as combinações de Lastro Hidro-eólicos avaliados. Pode-se observar também, assim como observado nos estudos de caso anteriores, que o preço do Lastro a partir do qual a decisão mais atraente para o investidor se torna realizar o investimento hoje, ou seja, sem custo de oportunidade associado, subiu em todos os casos avaliados.

\subsubsection{Conclusões do Estudo de Caso}

Todos os estudos de caso apresentados avaliam o benefício de se esperar para realizar um investimento. $\mathrm{O}$ valor de esperar para realizar um investimento reside em avaliar se as condições futuras acerca de um investimento tornariam algum momento mais propício para realizá-lo do que no presente.

Conforme (MEIRELLES, 2004), que cita (DIXIT e PINDYCK, 1994), a opção de adiar um investimento pode ser vista como o custo de oportunidade do investimento. $\mathrm{Ou}$ seja, investir hoje significaria anular essa opção devendo a empresa pagar por esse custo de oportunidade juntamente com o investimento inicial. 
Sendo assim, para que um investimento seja viável em t não é suficiente que tenha apenas o VPL tradicional positivo, mas sim que exceda o investimento somado ao custo de oportunidade.

De uma maneira geral, os estudos de caso realizados demonstraram a relevância da TOR para a análise do investidor quando da presença de incertezas na projeção de fluxo de caixa. Para cada um dos casos avaliados foi possível encontrar o preço do Lastro a partir do qual o investidor pode realizar hoje o investimento, sem estar renunciando a nenhum custo de oportunidade no capital empregado, permitindo ainda visualizar como o custo de oportunidade se comporta para valores de Lastro inferiores.

Da avaliação dos diferentes períodos de espera para o investimento foi possível observar um comportamento típico para os VPLs dos projetos com opção de espera e a manutenção do preço do Lastro numa mesma faixa de valor para a realização do investimento hoje. Além disso, observou-se também que para prazos menores de espera, em algumas situações a melhor decisão para o investidor é a de não investir.

Com relação à complementariedade Hidro-eólica, pode-se sim observar ganhos no investimento em conjunto, contudo, tal benefício variou em função do Lastro comercializado pela planta hidrelétrica. Nesse âmbito de análise, conclui-se que o investidor, ao avaliar novos investimentos na situação de comercialização em separado de Lastro e Energia, poderá ser valer de efeitos de complementariedade entre os projetos, para oferecer em leilões de Lastro, valores mais competitivos, sendo a TOR uma possível ferramenta.

Destaca-se aqui que, dentro dos custos levantados para a avaliação de investimentos, não foram considerados custos referentes aos estudos e trabalhos para o desenvolvimento dos projetos. Além disso, deve-se destacar também que o estudo não leva em consideração a estratégia de investimento com relação ao timming dos leilões. Destacase que diferentemente de outros mercados, onde o investimento pode ocorrer a qualquer momento, no Brasil, para que haja a aquisição dos PPAs regulados de longo prazo, é necessária a participação nos leilões centralizados.

De maneira geral, pode-se observar que uma retirada completa da comercialização de um contrato de longo prazo, com valor fixo, como é hoje proporcionado pelos leilões regulados, causaria um impacto direto na percepção de risco dos agentes geradores com relação a novos investimentos. 
Das avaliações de volatilidade realizadas, pode-se observar que tal componente pode ser reduzida à metade com a introdução dos contratos de Lastro, sendo, portanto, esta será uma importante variável de avaliação para os investidores, quando da separação dos produtos Lastro e Energia.

Por conseguinte, neste novo cenário, onde há a separação dos produtos Lastro e Energia, a percepção de risco e sua quantificação será cada vez mais importante, através de uma avaliação mais detalha de como as variáveis de risco influenciaram os retornos dos projetos. 


\section{CONSIDERAÇÕES FINAIS}

Desde a liberalização do mercado de energia elétrica Brasileiro, o governo atuou através de leilões de energia regulados para manter a adequação da expansão da geração, provendo aos vencedores contratos de longo prazo. Contudo, atualmente, como forma de promover a expansão do mercado livre de energia elétrica, o governo vem propondo mudanças importantes no desenho de mercado, sendo uma das mais relevantes a separação dos produtos 'Lastro' e Energia.

Nesse contexto, este trabalho aborda inicialmente uma revisão de modelos de arquitetura de mercado discutidos na literatura acadêmica, principalmente no que tange a adequação de oferta de energia elétrica, assim como também discute os mecanismos atualmente presentes no mercado brasileiro que contemplam esta função (seções 2 e 3).

Nessa linha, na seção 2, além da contexto geral de arquitetura de mercado, foram discutidos os conceitos pertinentes especificamente à adequação da oferta e pontuados o que seriam, de maneira simplificada, os dois tipos de mercados existentes para comercialização de energia elétrica, quais sejam, os mercados que comercializam apenas energia, conhecidos como Energy-Only Markets, e também os mercados que comercializam energia e capacidade, conhecidos como Capacity-Energy Markets. Além disso, expôs-se também a discussão acerca do Missing-Money Problem, que emerge da prática de preços teto em mercados competitivos de energia elétrica, o que acaba por limitar a sinalização adequada de preços para a expansão de plantas de geração de maior custo, que poderiam atuar principalmente no atendimento à demanda de ponta.

Já na seção 3, buscou-se aprofundar a discussão da arquitetura de mercado e da adequação da oferta dentro do contexto do setor elétrico brasileiro, elucidando quais os mecanismos presentes no desenho de mercado atual que atuam nesse sentido, e quais as propostas do governo para que, junto com a promoção da expansão do mercado livre, ou seja, o aumento da competição, se possa manter os requisitos de adequação.

Observa-se que, no mercado brasileiro até então, os mecanismos regulatórios existentes preocupavam-se exclusivamente com a contratação de montantes de energia, sem se atentar ao atendimento à demanda de ponta. Historicamente, a proporção dos reservatórios das hidrelétricas frente à carga, se fazia suficiente para o para lidar com necessidades de atendimento à ponta, através de um maior turbinamento de água no horário de maior demanda, quando necessário. 
Não obstante, a redução da expansão de hidrelétricas com grandes reservatórios, associada à expansão de fontes intermitentes, vem trazendo novos desafios ao operador de sistema no quesito ponta, emergindo daí a necessidade de revisão dos mecanismos vigentes.

Além disso, atualmente, o ACL representa cerca de $30 \%$ do consumo de energia nacional, mas, apesar disso, sua expansão não demonstrou que a simples necessidade do parque gerador por mais energia e os preços praticados no mercado de curto prazo, viessem a caracterizar uma sinalização suficiente para estimular uma expansão da geração de forma voluntária neste ambiente. Soma-se a isso as intenções governamentais expressas, em 2017, no âmbito da Consulta Pública do MME n³3 e, atualmente, através dos Grupos de Trabalho instituídos na Modernização do Setor Elétrico, que promovem uma mais expressiva e mais rápida abertura do mercado livre nos próximos anos.

Em face dessa conjuntura e sua evolução antevista, afigura-se necessário que a separação dos produtos Lastro e Energia seja efetivada, como forma de conciliar os anseios de expansão do mercado livre com a adequação da expansão da geração. Sendo assim, na nova arquitetura de mercado proposta o produto Lastro, dentro das várias dimensões que poderia vir a assumir (e.g. potência, confiabilidade, flexibilidade etc.), atuaria como uma medida para auxiliar na financiabilidade de novos projetos.

Destaca-se aqui, que considerando o conceito de Lastro, que caracteriza a capacidade que um gerador, ou eventualmente algum outro tipo de instalação, tem de atender à demanda em determinado momento e com um padrão de qualidade pré-estabelecido, a venda desse parâmetro, em conjunto com o produto Energia, acaba por misturar a gestão comercial com o que é segurança de suprimento. Portanto de uma maneira geral, a separação dos produtos Lastro e Energia se mostra uma evolução no quesito de realocação de responsabilidades e riscos dentro da expansão da geração.

Apesar de colocar a separação dos produtos Lastro e Energia como diretriz para a modernização do mercado brasileiro nos próximos anos, as autoridades governamentais não apresentaram, ainda, uma metodologia que definisse qual poderia vir a ser o preço destes produtos em separado. Neste contexto, portanto, este trabalho buscou avaliar do ponto de vista da financiabilidade, qual deveria ser o preço de venda dos produtos Lastro e Energia de diferentes tipos de fontes, de maneira a recuperar tanto o custo de investimento, quanto os custos de operação e manutenção destes parques. 
Para a análise de viabilidade econômica dos projetos de diferentes fontes de geração optou-se pela utilização da metodologia de Valuation, conforme é descrito e exemplificado na seção 4. Optou-se pela utilização da metodologia de Fluxo de Caixa Descontado por esta ser uma das mais sofisticadas para avaliação de geração de valor no longo prazo, pois, consegue capturar elementos intrínsecos do negócio em associação com a avaliação de expectativa de geração de receita futura.

Cabe observar que ainda na seção 4, foram discutidos os custos de investimento, operação, impostos e encargos que são aplicáveis neste caso e serviram para embasar os estudos.

Para que fosse realizada a precificação do Lastro, num primeiro momento foi realizada a precificação da Energia conforme descrito na seção 6.1. Para a precificação do preço da Energia foi utilizado um modelo de precificação de contratos futuros que tem como suporte uma parametrização de uma função de precificação com Algoritmos Genéticos, tendo por base (i) cenários de PLD passados e futuros, (ii) cotações de contratos observadas no mercado livre e (iii) o custo médio observado de expansão.

A partir desse modelo pode-se obter uma curva de preços de contratos para o mercado livre em linha com as práticas de mercado (“curva forward”).

Para a precificação do Lastro, descrita na 6.2, buscou-se mensurar o custo não recuperado pelo investidor no mercado livre e que poderia ser recuperado através de leilões centralizados, realizados pelo planejador central, com fulcro na premissa de desenho de mercado adotada nessa dissertação, que pondera o contexto atual mercadológico e regulatório do SEB.

Portanto, a lógica aqui é tal que o governo continuaria realizando leilões centralizados, que seriam operacionalizados estipulando-se um preço teto pelo Lastro, para cada tipo de fonte, a partir do que os empreendedores apresentariam deságios, conforme a competitividade das condições de investimento em novas plantas que encontrassem no mercado.

Estes contratos de Lastro teriam a duração similar às praticadas nos contratos comercialização regulados negociados hoje nos leilões de energia nova, contribuindo substancialmente para a aquisição de financiamentos para novos projetos. 
Os resultados obtidos, sensibilizados para diferentes taxas de retorno exigidas por acionistas/cotistas (Equity Internal Rate of Return) foram apresentados na seção 6.2.2, e são considerados como o preço teto a ser cobrado pelo Lastro, uma vez que considera valores conservadores de custos de investimento e operação, além de não considerarem possíveis subsídios e benefícios fiscais.

Uma vez obtidos valores teto do preço do Lastro para as diferentes fontes, a presente Dissertação propôs o Estudo de Caso onde um investidor pretende construir (i) uma hidrelétrica isoladamente e (ii) um parque gerador composto por uma hidrelétrica e uma eólica. Nesse estudo de caso pretendeu-se avaliar como a comercialização de Lastro e Energia em separado afetam a viabilidade de tais investimentos, e se a complementariedade entre as fontes eólica e hidrelétrica adiciona valor ao investimento.

Para tanto, utilizou-se a TOR, discutida na seção 5. A avaliação de projetos utilizando a TOR agrega o valor de flexibilidades gerenciais a avaliação tradicional de fluxo caixa descontado. No estudo de caso aqui apresentado estudou-se o benefício de postergar os investimentos propostos por um período de até cinco anos, dadas as incertezas avaliadas.

A avaliação de postergação de investimentos no setor elétrico é interessante dado o grande volume de investimento inicial necessário e também a característica irreversível de tais investimentos. Precifica-se aqui, então, o custo de oportunidade implícito do investidor quando exerce a opção de investir. Mais sobre a opção de espera é discutido na seção 6.3.4.

Foram consideradas como variáveis estocásticas nesse estudo de caso o (i) preço da energia, a (ii) geração hidrelétrica e a (iii) geração eólica. Para a modelagem do preço da energia e da geração hidrelétrica foram consideradas os cenários gerados pelo modelo NEWAVE. Conforme (STREET, LIMA, et al., 2012), com relação aos preços de curto prazo, no Brasil se verifica que tais preços são muito dependentes da política de operação adotada e, por essa razão, modelos de médio / longo prazos são considerados os melhores tipos de modelos de simulação para esta projeção no caso brasileiro, posto que preservam as características dinâmicas de mais longo prazo desta variável.

Para a geração eólica, a modelagem contou com a reconstrução de séries temporais de vento. A reconstituição da série diária com base nas características da série Vortex, onde é feita uma extrapolação vertical para a altura de interesse e uma análise estatística a partir da velocidade horária. Posteriormente, com a série NCAR, calcula-se o expoente 
da Lei de Potência (n), para o deslocamento da série na altura do aerogerador, com remoção de outliers, para posteriormente realizar também uma análise estatística. Ao final, a reconstrução das séries diárias é feita a partir da variabilidade diária do NCAR, e da velocidade média do Vortex. (Seção 6.3.4)

Os resultados dos Estudos de Caso estão expostos nas seções 6.3.5, 6.3.6 e 6.3.7. Num primeiro momento, avaliou-se o caso do investimento em uma planta hidrelétrica isoladamente, variando valores do contrato de Lastro. Num segundo momento, avaliouse o caso de investimento em um parque gerador composto por uma planta hidrelétrica (a mesma do primeiro caso) e uma planta eólica, onde a eólica não possui contrato de Lastro e o contrato de Lastro da hidrelétrica varia na mesma proporção do primeiro caso. No último caso, avaliou-se o caso de investimento em um parque gerador composto por uma planta hidrelétrica (a mesma do primeiro caso) e uma planta eólica, onde ambas possuem contratos de Lastro.

Dos estudos de caso avaliados, pode-se observar que uma retirada completa da comercialização de um contrato de longo prazo, com valor fixo, como é hoje proporcionado pelos leilões regulados, causaria um impacto direto na percepção de risco dos agentes geradores com relação a novos investimentos. A volatilidade do retorno dos projetos pode ser reduzida praticamente à metade com a introdução dos contratos de Lastro, sendo, portanto, uma importante variável de avaliação para os investidores, quando da separação dos produtos Lastro e Energia.

Neste novo cenário, onde há a separação dos produtos Lastro e Energia, a percepção de risco e sua quantificação será cada vez mais importante, através de uma avaliação mais detalhada de como as variáveis de risco influenciam os retornos dos projetos. Nesse contexto, a Teoria de Opções Reais se mostrou como adequada para tal tarefa, permitindo que o investidor encontre o preço adequado para a realização do investimento, levando em consideração as incertezas que afetam o fluxo de caixa do projeto.

Por fim, da avaliação dos projetos em conjunto, como é o caso avaliado do investimento em um projeto Hidro-eólico, observou-se que o valor necessário de Lastro a ser comercializado pela planta pode variar quando se considera o efeito portfólio entre projetos, inclusive podendo haver uma alocação diferente dos produtos entre os projetos. 
Por conseguinte, o investidor ao avaliar novos investimentos, quando houver a comercialização separada Lastro e Energia, poderá se valer de efeitos de complementariedade entre os projetos, permitindo oferecer valores mais competitivos em leilões de Lastro.

Como sugestões para próximos trabalhos aponta-se:

- A avaliação dos impactos da separação dos produtos Lastro e Energia sobre os preços praticados no mercado livre;

- A precificação das diferentes dimensões (e.g. potência, confiabilidade, flexibilidade etc.) do produto Lastro em separado;

- A avaliação da comercialização do produto Lastro de maneira não centralizada, ou seja, via mercado, aferindo-se se esta seria uma opção para obter um custo menor do produto, mantendo o mesmo nível de segurança de suprimento.

- O estudo de outras opções, como por exemplo a opção de expansão, ou ainda a opção de abandono em função da mudança da conjuntura de preços. 


\section{REFERÊNCIAS}

ABRACEEL. O Novo Setor Elétrico: O Setor Aguarda com Expectativa o Novo Modelo Proposto pelo Governo. Brasília. 2018.

ACER. Capacity Remuneration Mechanisms and the Internal Market for Electricity. Agency for the Cooperation of Energy Regulators. [S.1.], p. 31. 2013.

ANEEL. Cadernos Temáticos ANEEL: Energia Assegurada. Agência Nacional de Energia Elétrica. Brasília, DF. 2005.

ANEEL. Nota Técnica no 132/2018-SRM/ANEEL - Assunto: Abertura de Consulta Pública visandocoletar subsídios para o aprimoramento da metodologia de cálculo da Taxa Regulatória de Remuneração do Capital dos setores de distribuição, transmissão e geração de energia. Agência Nacional de Energia Elétrica. Brasília. 2018.

ANEEL. Proposta de abertura de audiência pública com vistas a obter subsídios e informações adicionais,para aprimorar o ato regulatório, a ser editado pela ANEEL, para regulamentar a metodologia para cálculo do valor de Uso de Bem Público UBP. Agência Nacional de Energia Elétrica. Brasília. 2018.

ANEEL. Nota Técnica no 169/2019- SGT/ANEEL. Agência Nacional de Energia Elétrica. Brasília, DF, p. 60. 2019.

ANEEL. Nota Técnica no 37/2019-SRM/ANEEL. Agência Nacional de Energia Elétrica. Brasília, p. 44. 2019.

ARROW, K. J.; FISHER, A. C. Environmental Preservation, Uncertainty, and Irreversibility. The Quarterly Journal of Economics, v. 88, n. 2, p. 312-319, Maio 1974.

ASSOCIAÇÃO BRASILEIRA DOS COMERCIALIZADORES DE ENERGIA (ABRACEEL). O Novo Setor Elétrico: O Setor Aguarda com Expectativa o Novo Modelo Proposto pelo Governo. Brasília. 2018.

BARDELIN, C. E. A. Os efeitos do Racionamento de Energia Elétrica ocorridos no Brasil em 2001 e 2002 com ênfase no Consumo de Energia Elétrica. São Paulo, Brasil. 2004. 
BASTOS, J. P. T. Uma Metodologia para a Separação da Comercialização de Energia e Lastro no Brasil através da Captura do Valor Econômico da Escassez no Mercado de Eletricidade. Rio de Janeiro. 2016.

BATISTA, F. R. S. Estimação do Valor Incremental do Mercado de Carbono nos Projetos de Fontes Renováveis de Geração de Energia Elétrica no Brasil: Uma Abordagem pela Teoria das Opções Reais. Tese de Doutora - PUC Rio. Rio de Janeiro. 2007.

BJERKSUND, P.; EKERN, S. Managing Investment Opportunities under Price Uncertainty: From "Last Chance" to "Wait and See" Strategies. Financial Management, v. 19, p. $65-83,1990$.

BLACK, F.; SCHOLES, M. The Pricing of Options and Corporate Liabilities. The Journal of Political Economy, v. 81, p. 637-654, May-Jun 1973.

BøCKMAN, T. et al. Investment timing and optimal capacity choice forsmall hydropower projects. European Journal of Operational Research , p. 255-267, 2008.

BOOMSMA, T. K.; MEADESTEIN, N.; FLETEN, E. Renewable energy investments under different support schemes:A real options approach. European Journal of Operational Research, v. 220, p. 225-237, 2012.

BRAGANÇA, G. G. F. D. O Financiamento de Energias Renováveis Alternativas no Brasil. Caderno Opinião - FGV Energia , p. 1-10, 2017.

BRASIL. Decreto n. 5.163, de 30 de jul. de 2004. Regulamenta a comercialização de energia elétrica, o processo de outorga de concessões e de autorizações de geração de energia elétrica, e dá outras providências., Brasília, DF, jul 2004.

BRASIL, H. G. et al. Opções Reais: Conceitos e Aplicações a Empresas e Negócios. Brasil: Editora Saraiva, 2007.

BRENNAN, M. J.; SCHWARTZ, E. S. A New Approach to Evaluating Natural Resource Investments. Midland Corporate Finance Journal, v. 3, p. 37-47, 1985.

CAPORAL, A.; BRANDÃO, L. E. T. Valuation of a power plant with the real options approach. Brazilian Business Review. Vitória, Espírito Santo, Brasil: [s.n.]. 2008. 
CFI. Options: Calls and Puts. Corporate Finance Institute, 2020. Disponivel em: $<$ https://corporatefinanceinstitute.com/resources/knowledge/trading-investing/optionscalls-and-puts/>. Acesso em: 11 set. 2020.

CHATTOPADHYAY, D.; ALPCAN, T. Capacity and Energy-Only Markets Under High Renewable Penetration. IEEE Transactions on Power Systems, v. 31, n. 3, p. 1692 1702, 2016.

COASE, R. H. The Problem of Social Cost. The Journal of Law and Economics Vol. 3, Outubro 1960. 1- 44.

COPELAND, T.; ANTIKAROV, V. Real Options: A practitioner`s guide. [S.1.]: Thomson Texere, 2003.

COX, J. C.; ROSS, S. A.; RUBINSTEIN, M. Option Pricing: A simplified approach. Journal of Financial Economics, Cambrig, v. 7, p. 229-263, 1979.

CRAMTON, P.; SOFT, S. The Convergence of Market Designs for Adequate Generating Capacity with Special Attention to the CAISO's Resource Adequacy Problem. [S.1.]. 2006.

DALBEM, M. C.; BRANDÃO, L. E. T.; GOMES, L. L. Can the regulated market help foster a free market for windenergy in Brazil? Energy Policy, p. 303-3011, 2014.

DAMODARAN, A. Damodaran on Valuation: Security Analysis for Investment and Corporate Finance. New Jersey. 2006.

DAMODARAN, A. Country Risk: Determinants, Measures and Implications - The 2018 Edition. New York. 2018.

DAMODARAN, A. Equity Risk Premiums (ERP): Determinants, Estimation and Implications - The 2018 Edition. New York University - Stern School of Business. [S.1.]. 2018.

DAMODARAN, A. The Promise and Peril of Real Options. New York.

DENG, S.-J.; JOHNSON, B.; SOGOMONIAN, A. Exotic Electricity Options and the Valuation of Electricity Generation and Transmission Assets. Decision Suport Systems, v. 30, p. 383-392, 2001.

DIAS, M. A. G. Investimento sob incerteza em exploração \& produção de petróleo. Rio de Janeiro. 1996. 
DIAS, M. A. G. Opções Reais Híbridas com Aplicações em Petróleo. Rio de Janeiro. 2005.

DIAS, M. A. G. Calculating Real Option Values in J.J. Cochran et al. [S.1.]: Wiley Encyclopedia of Operations Research and Management Science, 2011.

DIAS, M. A. G. Análise de Investimentos com Opções Reais - Volume 1: Conceitos Básicos e Opções Reais em Tempo Discreto. 1. ed. Rio de Janiero: Editora Interciência; Petrobras, 2014.

DÍAZ, G. et al. Valuation of wind power distributed generation by usingLongstaffSchwartz option pricing method. Applied Energy, p. 223-233, 2015.

DIXIT, A. K.; PINDYCK, R. S. Investment Under Uncertainty. Princeton: Princeton University Press, 1994.

DIXIT, R. K.; PINDYCK, R. S. Investment under Uncertainty. New Jersey: Princeton University Press , 1994.

DOREN, P. V. Making Sense of Electricity Deregulation. Regulation , v. 23, n. 3, p. 68$72,2000$.

EIA. Average Tested Heat Rates by Prime Mover and Energy Source, 2007-2017, 2018. Disponivel em: <https://www.eia.gov/electricity/annual/html/epa_08_02.html>. Acesso em: 19 Maio 2019.

EPE. Premissas e Custos da Oferta de Energia Elétrica no horizonte 2050 - NOTA TÉCNICA PR 07/18. Empresa de Pesquisa Energética e Ministério de Minas e Energia. Rio de Janeiro, RJ. 2018.

EPE. Informe: Custo do Gás Natural no Pré-Sal Brasileiro. Empresa de Pesquisa Energética; Ministério de Minas e Energia. Rio de Janeiro e Distrito Federal; Brasil. 2019a.

EPE. Custo Marginal de Expansão do Setor Elétrico Brasileiro Metodologia e Cálculo 2019. Rio de Janeiro, RJ. 2019b.

ERBACH, G. Capacity mechanisms for electricity. EPRS | European Parliamentary Research Service. [S.1.]. 2017. (PE 603.949).

FELDER, F. A. Integrating financial theory and methods in electricity resource planning. Energy Policy, v. 24, n. 2, p. 149-154, 1996. 
FERNANDES, B.; CUNHA, J.; FERREIRA, P. The use of real options approach in energy sector investments. Renewable and Sustainable Energy Reviews, v. 15, p. 4491-4497, 2011.

FGV. Acervo do Centro de Pesquisa e Documentação Histórica (CPDOC) e Conselho Nacional de Águas e Energia Elétrica (CNAEE). Fundação Getúlio Vargas. [S.1.].

FORTUNA, E. Mercado Financeiro: Produtos e Serviços. 19 Edição. ed. Rio de Janeiro: Qualitymark, 2013.

GOLDENBERG, J.; PRADO, L. T. C. Reforma e crise do setor elétrico no período FHC. São Paulo, Brasil. 2003.

GOMES, L. L.; BAIDYA, T. K. N.; MELO, A. C. G. Avaliação Termelétrica no Brasil Utilizando a Teoria de Opções Reais Considerando Incertezas Hidrológicas e de Expansão da Oferta. Centro de Pesquisas de Energia Elétrica (CEPEL). Rio de Janeiro, p. 20.2001.

GRUPO DE TRABALHO PARA APRIMORAMENTO DO MRE - GT - MRE. Relatório Técnico: "Avaliação dos Limites de Revisão de Garantia Física de Energia de Usinas HIdrelétricas". Brasília. 2017.

HENRY, C. Investment Decisions Under Uncertainty: The "Irreversibility Effect". The American Economic Review, v. 64, n. 6, p. 1006-1012, Dezembro 1974.

HERBELOT, O. Option Valuation of Flexible Investment: The Case Of a Scrubber for Coal-Fired Power Plant. Department of Nuclear Engineering. (PhD thesis). 1993.

HOGAN, W. W. On an "Energy Only" electricity market design for resource adequacy. Cambridge, Massachusetts. 2005.

HÖRNLEIN, L. The value of gas-fired power plants in markets with high shares of renewable energy: A real options application. Energy Economics, p. 1078-1098, 2019.

HUNTINGTON, H. G.; CHAO, H.-P. Designing competitive electricity markets. Boston. 1998.

IRENA. Renewable Power Generation Costs in 2017. Abu Dhabi: International Renewable Energy Agency, IRENA, 2018. 
IRENA. Renewable Power Generation Costs in 2018. Abu Dhabi, United Arab Emirates. 2019.

JOELSAS, D.; LYRA, D. Precificação de Contratos de Energia Baseada em Modelos Estocásticos. Escola Politécnica da USP: Trabalho de Formatura (Orientador: Prof. Dr. Dorel Soares Ramos), 2015.

JOSKOW, P. L. Competitive Electricity Markets and Investments in New Generating Capacity. Massachussets, USA. 2006.

JOSKOW, P. L. Lessons Learned from Electricity Market Liberalization. The Energy Journal, v. 29, p. 9-42, 2008.

JOSKOW, P. L.; SCHMALENSEE, R. Markets for Power: An Analysis of Electric Utility Deregulation. Cambridge, Massachusetts. 1983.

JOSKOW, P.; SCHMALENSEE, R. Markets for Power: An Analysis of Electric Utility Deregulation. Cambrigde, Massachusetts. 1983.

KEMNA, A. G. Z. Case Studies on Real Options. Financial Management, v. 22, p. 259$270,1993$.

KITZING, L. et al. A real options approach to analyse wind energy investments underdifferent support schemes. Applied Energy, v. 188, p. 83-96, 2017.

LINTNER, J. The valuation of risk assets and the selection of risky investments in stock portfolios and capital budgets. Review of Economics and Statistics, Cambridge, v. 47, n. 1, p. 13-37, 1965.

LIU, X.; RONN, E. I. Using the binomial model for the valuation of real options in computingoptimal subsidies for Chinese renewable energy investments. Energy Economics, v. 87, 2020.

MACHADO, R. C. Geração de Cenários Hidroeólicos para o Planejamento da Operação Energética de Médio Prazo via Modelo Auto-Regressivo Periódico. Universidade Federal de Santa Catarina (UFSC), Florianópolis: Dissertação de Mestrado, 2016.

MARRECO, J. D. M. Planejamento de Longo Prazo da Expansão da Oferta de Energia Elétrica no Brasil sob um Perspectiva da Teoria de Opções Reais. Tese de Doutorado - COPPE/UFRJ. Rio de Janeiro. 2007. 
MAZER, A. Electric Power Planning for Regulated and Deregulated Markets. Estados Unidos da América: Wiley-IEEE Press, 2007.

MCDONALD, R. L.; SIEGEL, D. The Value of Waiting to Invest. Quarterly Journal of Economics, v. 101, p. 707-727, 1986.

MEIRELleS, J. L. F. A Teoria de Opções Reais como Instrumento de Avaliação de Projetos de Investimento. São Carlos. 2004.

MENDES, R. M. Opções Reais em Project Finance: Uma Aplicação na Indústria Petrolífera. Rio de Janeiro, Brasil. 2012.

MERCEDES, S. S. P.; RICO, J. A. P.; POZZO, L. D. Y. Uma revisão histórica do planejamento do setor elétrico brasileiro. Revista USP, Janeiro, Fevereiro, Março 2015. 13-36.

MERTON, R. An intertemporal capital asset pricing model. Econometrica, v. 41, n. 5, p. pp. 867-887, Setembro 1973.

MF. Metodologia de Cálculo do WACC: Concessões Pública. Brasília, DF: Ministério da Fazenda, 2018.

MINISTÉRIO DA FAZENDA. Metodologia de Cálculo do WACC: Concessões Pública. Brasília, DF: [s.n.], 2018.

MME. Boletim Mensal de Acompanhamento Da Indústria de Gás Natural Maio de 2015. Ministério de Minas e Energia. Brasília, DF, Brasil. 2015.

MME. Boletim Mensal de Acompanhamento da Indústria de Gás Natural 2019. Ministério de Minas e Energia. Brasília, DF, Brasil. 2019.

MODIGLIANI, F.; MILLER, M. The cost of capital, corporation finance and the theory of investment. The American Economic Review, v. v.XLVIII, n. n.3, p. p. 261-297, 1958.

MODIGLIANI, F.; MILLER, M. The cost of capital, corporation finance and the theory of investment. American Economic Review, v. v. 48, Junho de 1958.

MOREIRA, A. R. B.; DAVID, P. A. M.-S.; ROCHA, K. Regulação do Preço da Energia Elétrica e Viabilidade de Investimento em Geração no Brasil. Rio de Janeiro, Brasil. 2003. 
MOREIRA, A. R. B.; DAVID, P. A. M.-S.; ROCHA, K. Themopower Generation Investment in Brasil - Economic Conditions. Energy Policy , v. 32, p. 91-100, 2004.

MOSSIN, J. Equilibrium in a capital asset market. Econometrica: Journal of the econometric society, Oxford, v. 34, n. 4, p. 768-783, 1966.

MUMMEY, J. F. C. Uma Contribuiçãa Metodológica para a Otimização da Operação da Expansão do Sistema Hidrotérmico Brasileiro Mediante a Representação Estocástica da Geração Eólica. Universidade de São Paulo, São Paulo: Tese de Doutorado, 2017.

MYERS, S. C. Determinants of Corporate Borrowing. Journal of Financial Economics, v. 5, p. 147-175, Novembro 1977.

NETO, A. A. Valuation - Métricas de Valor \& Avaliação de Empresas. São Paulo: Editora Atlas S.A., 2014.

NEWBERRY, D. Privatization, Restructuring and Regulation of Network Utilities (The Walras-Pareto Lectures). Cambridge, Massachusets. 2001.

NUNES, L. E. Valoração de Projetos de Energia Alternativa Renovável (EAR) Sob a Ótica de Opções Reais. Florianópolis. 2017.

OFGEM. Electricity security of supply. A commentary on National Grid's Future Energy Scenarios for the next three winters. OFGEM. Londres, p. 24. 2015.

P\&D ANEEL. Arquitetura de Mercado para a Comercialização de Energia Elétrica no Brasil: Análise, Simulação e Propostas - Relatório Técnico I: Revisão da Literatura. Brasília. 2014.

P\&D CESP. Metodologia e Ferramental para Previsão de Energias Naturais Afluentes e Precificação de Contratos Aplicados à Definição de Estratégia Ótima de Contratação para Empresas Geradoras, Incluindo Energia Existente e Novos Emprrendimentos. São Paulo: Relatório Final, 2015.

P\&D DUKE ENERGY. Sistema Computacional para a Precificação de Contratos Bilaterais de Energia Elétrica, com o suporte de algoritmos genéticos e técnicas avançadas de previsão de preços de médio e longo prazos. São Paulo: Relatório I, 2015. 
PADDOCK, J. L.; SIEGEL, D. R.; SMITH, J. L. Option Valuation of Claims on Real Assets: The Case of Offshore Petroleum Leases. The Quarterly Journal of Economics, v. 103, p. 479-508, August 1988.

PASSOS, A. C.; STREET, A.; BARROSO, L. A. A Dynamic Real Option-Based Investment Model for Renewable Energy Portfolios. IEEE Transactions on Power Systems, v. 32, n. 2, p. 883 - 895, Março 2017.

PIGOU, A. C. The Economics of Welfare. Londres: Macmillan and Co., Limited, 1920. PLESS, J. et al. Quantifying the value of investing in distributed natural gas and renewable energy systems as complements: Application of discounted cash flow and real option analysis with stochastic inputs. Energy Policy, 4 Agosto 2016. 378-390.

PSR. Energy Report Edição 153. PSR. Rio de Janeiro, p. 48. 2019.

RAMOS, D. S.; SUSTERAS, L. G. Utilização de algoritmos genéticos para previsão da contratação de energia pelas distribuidoras. IEEE Latin America Transactions: IEEE, 2006. ISBN v. 4, n. 4, p. 268-278.

RODILLA, P.; BATLLE, C. Security of Electricity Supply at the Generation Level: Problem Analysis. Energy Policy, v. 40, p. 177-185, 12 Novembro 2012.

RONN, E. I. Real Options and Energy Management: Using Options Methodology to Enhance Capital Budgeting Decisions. [S.1.]: Risk Books, 2002.

ROTH, A. E. What have we learned from market design ? Economic Journal (Royal Economic Society), v. 118, n. 527, p. 285-310, 2008.

SAMUELSON, P. A. Proof that Properly Antecipated Prices Fluctuate Randomly. Industrial Management Review, p. 41-49, 1965.

SANTOS, L. et al. Real Options versus Traditional Methods to assess Renewable Energy Projects. Renewable Energy, 19 Março 2014. 588-594.

SHARPE, W. F. Capital asset prices: a theory of market equilibrium under conditions of risk.. Journal of Finance, v. 19, n. 3, p. 425-442, 1964.

SILVA, E. F. D. Pricipais Condicionantes das Alterações no Modelo de Comercialização de Energia Elétrica: Retrospectiva e Análise Crítica. São Paulo. 2008 . 
SOKEI, C. T. Modelo de sazonalização de energia assegurada de usinas hidrelétricas utilizando algoritmos genéticos. Escola Politécnica da USP. São Paulo, SP, Brasil. (Orientador: Prof. Dr. Dorel Soares Ramos) 2008.

STREET, A. et al. Fostering Wind Power Penetration into the Brazilian ForwardContract Market. San Diego, CA, USA: 2012 IEEE Power and Energy Society General Meeting. 2012.

TEISBERG, E. O. An Option Valuation Analysis of Investment Choices by a Regulated Firm. Management Science, v. 40, p. 535-548, 1994.

TOLMASQUIM, M. T. Energia Renovável - Hidráulica, Biomassa, Eólica, Solar e Oceânica. Rio de Janeiro: Empresa de Pesquisa Energética, 2016.

TOLMASQUIM, M. T. Energia Termelétrica: Gás Natural, Biomassa, Carvão, Nuclear. Rio de Janeiro: Empresa de Pesquisa Energética (EPE), 2016.

TOURINHO, O. A. F. The Valuation of Reserves of Natural Resources: An Option Pricing Approach. Berkeley. 1979.

TRIGEORGIS, L. Real Options in Capital Investment: Models, Strategies an Applications. Westport: Praeger, 1995.

VRIES, L. D.; HEIJNEN, P. The Impact od Electricity Market Design upon Invetment under Uncertainty: The Effectiveness of Capacity Mechanisms. Utilities Policy, v. 16, p. 215-227, 2007.

WILSON, R. Architecture of Power Markets. Econometrica, v. 70, n. 4, p. 1299-1340, 2002.

WITZLER, L. T. Metodologia para Reconstrução de Séries Históricas de Vento e Geração Eólica Visando a Análise da Complementariedade Energética no Sistema Interligado. Escola Politécnica da USP: Dissertação de Mestrado (Orientador: Prof. Dr. Dorel Soares Ramos), 2015.

WOLAK, F. A. Designing Competitive Wholesale Electricity Markets - Prepared for the First Meeting of the Latin American Competition Forum. Stanford University. Paris. 2003. 